\title{
Drinksituaties en drinkgedrag : alcoholgebruik in het dagelijks leven
}

Citation for published version (APA):

van Gelooven, R. M. W. (1990). Drinksituaties en drinkgedrag : alcoholgebruik in het dagelijks leven.

[Doctoral Thesis, Maastricht University]. Rijksuniversiteit Limburg. https://doi.org/10.26481/dis.19901213rg

Document status and date:

Published: 01/01/1990

DOI:

10.26481/dis.19901213rg

Document Version:

Publisher's PDF, also known as Version of record

\section{Please check the document version of this publication:}

- A submitted manuscript is the version of the article upon submission and before peer-review. There can be important differences between the submitted version and the official published version of record.

People interested in the research are advised to contact the author for the final version of the publication, or visit the DOI to the publisher's website.

- The final author version and the galley proof are versions of the publication after peer review.

- The final published version features the final layout of the paper including the volume, issue and page numbers.

Link to publication

\footnotetext{
General rights rights.

- You may freely distribute the URL identifying the publication in the public portal. please follow below link for the End User Agreement:

www.umlib.nl/taverne-license

Take down policy

If you believe that this document breaches copyright please contact us at:

repository@maastrichtuniversity.nl

providing details and we will investigate your claim.
}

Copyright and moral rights for the publications made accessible in the public portal are retained by the authors and/or other copyright owners and it is a condition of accessing publications that users recognise and abide by the legal requirements associated with these

- Users may download and print one copy of any publication from the public portal for the purpose of private study or research.

- You may not further distribute the material or use it for any profit-making activity or commercial gain

If the publication is distributed under the terms of Article $25 \mathrm{fa}$ of the Dutch Copyright Act, indicated by the "Taverne" license above, 


\section{Drinksituaties en drinkgedrag Alcoholgebruik in het dagelijks leven}





\title{
Drinksituaties en drinkgedrag Alcoholgebruik in het dagelijks leven
}

\author{
PROEFSCHRIFT
}

ter verkrijging van de graad van doctor aan de

Rijksuniversiteit Limburg te Maastricht, op gezag van de Rector Magnificus, Prof. dr. F.I.M. Bonke

volgens het besluit van het College van Decanen, in het openbaar te verdedigen op donderdag 13 december 1990 om vier uur

door

Renier Maria Wilhelmus van Gelooven

geboren te Maastricht in 1963 
Promotor: Mevr. Prof. dr. M.J. Drop

Co-Promotor: Dr. J.P.M. Diederiks

Beoordellingscommissie

Prof. dr. ir. A.P.W.M. Appels (voorzitter)

Prot. dr. M. Elchardus (Vrije Universiteit, Brussel)

Dr. H.F.L. Garretsen (GG\&GD, Rotterdam)

Prof. dr. G.J. Kok

Prot. dr. M.W. de Vries

CIP-GEGEVENS KONINKLIJKE BIBLIOTHEEK, DEN HAAG

Gelooven, Renier Maria Wilhelmus van

Drinksituaties en drinkgedrag: alcoholgebruik in het dagelijks leven / Renier Maria Wilhelmus van Gelooven. Maastricht : Datawyse. - III.

Proefschrift Maastricht. - Met lit. opg. - Met samenvatting in het Engels.

ISBN 90-5291-037-5

SISO 614.72 UDC 316.6:613.81(043.3) NUGI 651

Trefw.: alcoholgebruik.

Ontwerp omslag

Jack van Gelooven 


\section{Inhoudsopgave}

Voorwoord

Hoofdstuk 1

Regelmaat in drinkgedrag:

sociale gewoonten en rollen

I.1 Inleiding

1.2 Structuur en gedrag

1.3 Temporele orde

1.4 Het dagelijks leven

$\begin{array}{lll}1.5 & \text { Gewoonten } & 18\end{array}$

$\begin{array}{llr}1.6 & \text { Rollen } & 19\end{array}$

$\begin{array}{lll}1.7 & \text { Conclusies } & 21\end{array}$

Hoofdstuk 2

Tijdbesteding en alcoholgebruik:

registratiemethoden en data

$2.1 \quad$ Inleiding

Tijdbestedingsonderzoek

Observaties

Open of gesloten activiteitenregistratie $\quad 26$

$\begin{array}{ll}\text { Continue of gefixeerde registratie } & 27\end{array}$

De duur van de onderzoeksperiode 27

$\begin{array}{ll}\text { Toegevoegde informatie } & 28\end{array}$

$\begin{array}{lll}2.3 & \text { De registratie van drinkgedrag } & 28\end{array}$

$\begin{array}{lll}2.3 .1 & \text { De weekly recall methode } & 29\end{array}$

$\begin{array}{lll}2.3 .2 & \text { De time-line methode } & 30\end{array}$

$\begin{array}{ll}2.3 .3 & \text { De last-occasion methode } \\ 2.3 .4\end{array}$

2.3.4 Allcoholdagboeken 31

2.3.5 Het tijdbestedingsdagboek als instrument 32 
2.4.1 De steekproef 33

2.4.2 De dagboekvragenlijst 34

$2.5 \quad$ Analyse, eenheden en maten 35

2.5.1 Drinkgedrag tijdens de dagboekweek 36

\section{Hoofdstuk 3}

Sociale drinkgewoonten:

drinksituaties in Nederland

$3.1 \quad$ Inleiding

3.1.1 Drinkgelegenheden en drinksituaties 41

3.1.2 De drinkgewoonten in Nederland 42

$3.2 \quad$ Vraagstellingen 44

$3.3 \quad$ Methode 45

3.3.1 Variaties in drinkgedrag naar tijdstip 46

3.3.2 Variaties in drinkgedrag naar activiteit per periode 49

3.4 De definitie en beschrijving van drinksituaties 49

$\begin{array}{lll}3.4 .1 & \text { Definitie van drinksituaties } & 49\end{array}$

$\begin{array}{lll}3.4 .2 & \text { Beschrijving van drinksituaties } & 51\end{array}$

De mannern 51

De vrouwen 54

Verdeling van drankgebruik over lokaties $\quad 56$

$3.5 \quad$ Drinkgewoonten en de zwaarte van het drinkgedrag 56

3.5.1 De hypothesen 56

$\begin{array}{lll}3.5 .2 & \text { Methoden } & 57\end{array}$

$\begin{array}{lll}3.5 .3 & \text { Resultaten } & 59\end{array}$

De mannen $\quad 59$

De vrouwen $\quad 60$

3.6 Conclusies en discussie 62

Hoofdstuk 4

Rollen en drinkgedrag:

vragen, hypothesen en methoden 67

$\begin{array}{lll}4.1 & \text { Inleiding }\end{array}$

4.1.1 Een algemeen model 68

$\begin{array}{lll}4.1 .2 & \text { Rollen en drinkgedrag } & 69\end{array}$

4.1.3 Tijdbestedingsonderzoek en de gelegenheid tot drankgebruik 73 
$\begin{array}{lll}4.2 & \text { Vragen en veronderstellingen } & 80\end{array}$

Proposities: expositie en consumptie $\quad 80$

Proposities: rollen en expositie $\quad 81$

Proposities: rollen en realisatie $\quad 82$

Proposities: consumptieniveau en rollen 83

4.3 Methode 83

4.3.1 Inleiding 83

4.3.2 De variabelen 84

$\begin{array}{lll}4.3 .3 & \text { De operationele hypothesen } & 87\end{array}$

Hypothesen over rollen en expositie $\quad 87$

Hypothesen over expositie en consumptie $\quad 87$

Hypothesen over rollen en realisatie 88

Hypothesen over consumptiemiveau en rollen $\quad 89$

$\begin{array}{lll}4.3 .4 & \text { De analyses } & 90\end{array}$

De logit-analyse $\quad 93$

De multiple regressie analyse 94

Overige analyses 95

$\begin{array}{lll}4.4 & \text { Overzicht van analyses en hypothesen } & 97\end{array}$

Hoofdstuk 5

Rollen en expositie,

expositie en consumptie $\quad 99$

$\begin{array}{lll}5.1 & \text { Rollen en expositie } & 99\end{array}$

De mannen $\quad 99$

De vrouwen 103

Conclusies, rollen en expositie 106

$\begin{array}{lll}5.2 & \text { Expositie en consumptie } & 107\end{array}$

De mannen $\quad 107$

De vrouwen 108

Conclusies, expositie en consumptie 109

$\begin{array}{lll}5.3 & \text { Algemene conclusies } & 110\end{array}$

Hoofdstuk 6

Rollen en consumptie

6.1 Rollen en al dan niet drinken 111

De mannen $\quad 112$

De vrouwen $\quad 114$

Conclusies $\quad 115$ 
6.2 Rollen en intensiteit van drinkgedrag

De mannen

De vrouwen

Conclusies

6.3 Consumptieniveau en rollen

$6.4 \quad$ Algemene conclusies

\section{Hoofdstuk 7}

Samenvatting en discussie

Drinksituaties en sociale drinkgewoonten

Rollen en drinkgedrag

Verschillen in drinkgedrag naar consumptieniveau

Rollen en consumptieniveau

Structurerende rolien en drinkgedrag

\section{Summary}

\section{Literatuurlijst}

Bijlage 2.1

Een bladzijde uit het dagboek

Bijlage 2.2

De activiteitencategorieën en daarbij behorende toelichting

Bijlage 3.1

Drinkgelegenheden waarbij meer dan $1 \%$ van de populatie

alcohol gebruikt

Bijlage 3.2

Frequentie als maat voor zwaarte van het

drankgebruik

Bijlage 4.1

De resultaten wan de analyses per drinksituatie

afzonderijk bij de mannen

Bij]age 4.2

De resultaten van de analyses per drinksituatie

afzonderijik bij de vrouwen 
Nu ik dit voorwoord schrijf besef ik dat het grootste deel van het werk an dit proefschrift er echt op zit. Noodgedwongen heb ik na het gereedkomen van het manuscript voor de leescommissie, een aantal weken moeten pauzeren. Dat heeft als voordeel gehad dat ik nu met een 'beetje" afstand kan terugkijken op de totstand koming van dit boek.

Opvallend is dat ik wel vaker dacht dat het nu wel bijna af was. Vaak moest ik op clie gedachte terugkomen. Opmerkelijk is dat mijn collega's en begeleiders ondanks dat, tocla in mij bleven geloven. Meer nog dan ik dat zelf soms deed. Vooral de laatste maanden namen de twijtels bij mij en het vertrouwen bij hen toe. Ik wil op de eerste plaats iedereen bedanken voor de steun die dit vertrouwen in mij, voor me heeft betekent.

Natuurlijk geldt dat in sterke mate woor de leden van de projectgroep, mijn directe begeleiders Riet, Jos en Ronald. Zij hebben mij, tijdens mijn jaren bij medische sociologie, genoeg met rust gelaten om mijn eigen gang te gaan en tegelijkertijd voldoende gestimuleerd en met (zachte) dwang aangezet om door te werken. Naast de onmisbare inhoudelijke en methodologische steun, is dit zeer nuttig geweest. Dan zwijg ik nog over al het geregel geschrijf en gebel dat de promotor voor haar rekening moet nemen. Riet, hiervoor mijn extra dank.

Elke promovendus komt, denk ik, in de verleiding om iedereen persoonlijk te bedanken in het voorwoord van zijn of haar proefschrift. Ik geef aan die verleiding niet toe. Een atntal mensen mogen echter niet onvermeld blijven.

Ien, Paul en Mieke, jullie kan ik zeker niet overslaan.

Ien, nilet alleen omdat je mij altijd mijn middagslaapje ongestoord liet genieten maur ook omdat je steeds bereid was om te luisteren naar mijn al dan niet uitgewerkte ideëen of voorstellen en daar meestal positiel tegenoverstond. Als ik jou maar half zoveel gestinuleerd heb als jij mij, verdien ik zeker een plaatsje in het voorwoord wan jouw proefschrift.

Paul, omdat jij nooit iets als vanzelfsprekend aannam. Overal had jij je kanttekeningen bij en je makte ook altijd tijd om deze uiteen te zetten. Soms was dit vervelend, meestal stimulerend en altijd enerverend.

Mieke, natuurlijk voor je computerwerk in de beginfase van het onderzoek, mar meer nog woor het feit dat je, althans de eerste helft van de week, het werken extra prettig makkte, alleen al door aanwezig te zijn. Je was dan wel van mening dat men zijn (ik mijn) jonge leven niel in een duf kantoor hoorde door te brengen (en daar heb je gelijk in) maar zorgcle tegelijkertijd woor genoeg lol om dat toch te doen.

De overige leden van de vakgroep medische sociologie zorgden samen met bovengenoemden 
voor de werksfeer. Ik kan me niet herinneren ocit met tegenzin nar mijn werk te zijn gekomen. Dat is jullie verdienste.

Een woord van dank is hier zeker ook op zijn plaats voor alle respondenten die de niet geringe inspanning om het dagboek een week lang bij te houden hebben geleverd.

Naast collega's en respondenten zijn er nog enkele mensen die ik in het bijzonder wil bedanken. Marijke, jij komt darbij met meer dan een neuslengte voorsprong, op de eerste plats. De afgelopen jaren, maar vooral die laatste paar maanden, was jouw ondersteuning, zowel in praktische als emotionele zin, meer dan noodzakelijk. Hiervoor bedank ik je van harte.

Jack, met jouw werk begint en eindigt dit proefschrift. Bedankt voor het ontwerp en de uitvoering wan de omslag.

Voor de lezers tenslotte, hoop ik dat ze evenveel genoegen mogen beleven aan het lezen van dit proefschrift als ik aan het werk eraan heb gehad. 


\section{Hoofdstuk 1 \\ Regelmaat in drinkgedrag: \\ sociale gewoonten en rollen}

\subsection{Inleiding}

Het thema van dit proefschrift is alcoholgebruik in het dagelijks leven. In dit eerste hoofdstuk wordt het theoretisch kader van de studie beschreven. Er wordt getracht regelmatigheden in gedrag en systematische verschillen in het gedrag van verschillende individuen te verklaren.

Het dagelijks leven is geen chaos. De meeste mensen zijn meestal redelijk in staat te begrijpen en te voorspellen hoe anderen zich gedragen of zullen gedragen: regelmaat is geen probleem in het dagelijks leven. Het zijn de onvoorspelbare, afwijkende gebeurtenissen waarover men zich verwondert, waarvoor men een verklaring zoekt. Uitgaandle van de vrije wil van het individu en het weinig restrictieve karakter van onze samenleving zijn echter de regelmatigheden in gedrag eerder verbazingwekkend dan vanzelfsprekend. Hoe is het mogelijk dat men steeds dezelfde drankjes op dezelfde platsen en tijden drinkt? Waarom werwondert men zich niet over het drinken in een café, nuar wel over een aangebroken fles jenever op de toonbank bij de kruidenier.

Vanzelfsprekend gedraagt niet iedereen zich op dezelfde wijze. De koning drinkt, de boer en de arbeider ook. Ze drinken echter niet allemaal op dezelfde manier. Verschillen tussen individuen bestaan maar zelfs deze zijn vaak systematisch en dus regelmatig. Het likeurtje is woor mevrouw, het pils woor meneer, althans zo neemt de kelner vamzelfsprekend aan en dat is geen persoonlijke eigenaardigheid.

Kort gesteld zijn de basale vragen waarop in dit hoofdstuk wordt ingegaan: hoe kan uniformiteit in (drink)gedrag worden verklaard en hoe kunnen systematische verschillen in (drink)gedrag tussen individuen worden verklaard.

Drinken is een vorm van gedrag. Algemene theorieën die gelijkvormigheden en verschillen in gedrag verklaren worden daarom ook van toepassing geacht op drinken. In dit hoofidstuk worden deze algemene theorieën beschreven. Eersit wordt ingegaan op de relatie tussen het individu en de sociale structuur. Er wordt een standpunt ingenomen ten aanzien van de wijze 
waarop structuur en gedrag zich verhouden. Vervolgens wordt de aard van de orde in onze samenleving beschreven. De orde in de thedendaagse samenleving is sterk verbonden met klokken en kallenders. De tijd speelt een belangrijke rol in de beoordeling van de 'normaluteit' of gepastheid van gebeurtenissen om ons heen.

$\mathrm{Na}$ de algemene inleiding op het theoretisch kader wordt het dagelijks leven onder de loep genomen. Er wordt beschreven hoe voor de waarnemer, de sociale wetenschapper het dagelijks leven uiteen is te leggen in zinvol te onderscheiden onderdelen. Daarna wordt beschreven uit welke onderdelen het dagelijks leven voor het handelend individu bestaat. In deze uiteenzetting komt ook de definitie van elementen van gedrag als activiteiten of handelingen aan de orde. Drinkgedrag is een handeling, het ontleent zijn betekenis aan de temporele lokatie waar en aan de activiteit waarbij het plaatsvindt.

De wijze waarop individuen hun gedrag afstemmen op de handelingsruimte, de ervaren situatie, en de semi-automatische gedragspatronen die betiteld worden als gewoonten kunnen verklaren hoe gelijkvormigheden in gedrag tot stand komen. Sociale gewoonten in het bijzonder zullen gebruikt worden om te verklaren waarom verschillende mensen zich, geconfronteerd met gelijke situaties, op dezelfde wijze gedragen.

Verschillen in gedrag kunnen voor een deel verklaard worden uit de rollen die mensen vervullen. Ook ten aanzien van drinkgedrag mag een invloed van rollen niet worden uitgesloten. Welke rollen kunnen worden onderscheiden en op welke manier deze met drinkgedrag samenhangen, wordt in het laatste deel van dit hoofdstuk beschreven. Er wordt gesteld dat met name status- en positierollen kunnen verklaren waarom er systematische verschillen in drinkgedrag tussen categorieên van sociale actoren bestaan.

De algemene ideeën die in dit hoofdstuk worden gepresenteerd, worden in de rest van dit proefschrift verder uitgewerkt. In de laatste paragraaf van dit hoofdstuk worden enkele keuzes, die aan de benadering in de volgende hoofdstukken ten grondslag liggen, expliciet gemakt.

\subsection{Structuur en gedrag}

De studie van het alledaagse gedrag behoort tot het terrein van de micro-sociologie. Ze onderscheidt zich daarin van de macro-sociologie, de studie van 'large-scale' sociale systemen zoals bijvoorbeeld bedrijven, het politieke systeem of de economische orde. Giddens (1989) noemt twee redenen waarom de studie van het dagelijks gedrag belangrijk is voor de sociologie:

1) Het alledaggse gedrag vormt het grootste deel van alle sociale activiteiten. De routines van het dagelijks leven en de daarin plaatsvindende interacties met anderen geven structuur en vorm aan menselijk gedrag.

2) De studie van het alledaagse gedrag geeft ook inzicht in grotere sociale systemen en instituties. Alle grootschalige systemen berusten uiteindelijk en in feite op de patronen van sociale actie zoals die in het dagelijks leven door de individuele sociale actoren worden gerealiseerd.

Het dagelijks leven bestaat niet uit een willekeurige verzameling van gebeurtenissen of handelingen. Er zijn regelmatigheden en patronen in het menselijk handelen en de relaties 
wussen mensen. Dergelijke patronen vormen de sociale structur. Bij de studie van het alledaagse gedrag en zeker bij pogingen om dat gedrag te verklaren is een confrontatie met een van de fundamentele theoretische dilemma's in de sociologie, namelijk het dilemma van structuur en actie, onvermijdelik. Dit dilemma betreft de vraag of het handelien van individuele sociale actoren voortkomt uit, of sterker gedetermineerd is door de sociale structuur of dat deze structuur het resultaat is van het handelen van de individuele socialle actoren. Wordt gedrag bepaald door de structuur of de structuur door het gedrag?

Hier wordt uitgegaan van het standpunt dat sociale structuren het produkt zijn van menselijk handelen en tegelijkertijd dat menselijk handelen bepalen. De sociale structuur kan worden gezien als het geheel van richtlijnen voor gedrag. Mensen stemmen hun gedrag af op de formele regels, informele verwachtingen en de daabij horende sancties en controlte mechanismen. Hierdoor reconstrueren de sociale actoren steeds opnieuw de socialle structuren waarop zij hun handelen afstemmen (Giddens, 1984; Giddens, 1989). De relatie tussen structuur en gedrag is dus niet deterministisch.

De structuur bestaat vanwege en is de oorzaak van de continuteit in de manier warop mensen hun gedrag inrichten. De continue aspecten van de sociale structuur kunnen omschreven worden als de sociale orde. In de nu volgende paragraaf zal worden omschreven welke vorm de orde in onze samenlleving heeft.

\subsection{Temporele orde}

De regelmatighedlen en veranderingen in een sociaal systeem kunnen worden begrepen en beschreven aan de hand van de temporele organisatie van dat systeem. Elchardus (1985) definieert tijd als: "Elk begrip dat ons toestaat oordelen te vellen over de veranderlijkheid of onveranderlijkheid wan fenomenen, en dat ons tevens de mogelijkheid biedt gebeurtenissen transitief te ordenen in termen van woor of na'. Hij stelt verder dat tussen tijd en orde geen prioriteit kan worden gesteld. De ene komt niet voort uit de andere. De ene is niet denkbaar zonder de andere.

Zerubavel $(1979 ; 1984)$ omschrijft de orde in de westerse geïndustrialiseerde samenleving als de 'Socio-Temporele Orde'. De aard van deze orde wordt gereflecteerd door de instrumenten die gebruikt worden om tijd te meten en tijdstippen vast te stellen: de klok, de kalender en de agenda. Het sociale leven is georganiseerd op een wijze gesymboliseerd door deze instrumenten. Zerubavel (1984) onderscheidt vier dimensies in de rigide sociotemporele orde in onze westerse samenleving: waste duur, waste tijdstippen, rigide volgordes en vaste ritmes. In tegenstelling tot de traditionele samenlevingen is de tijd in onze maatschappij abstract, haar elementen zijn uniform en precies. Er kan mee worden gerekend (Pronovost, 1989). Tijd is geld.

De organisatie van onze metronomische samenleving (Young, 1988) vond haar porsprong in de op klokken afgestemde organisatie van het leven in de middeleeuwse Benedictijner kloosters. Het kwantitatieve, mathematisch precieze tijdsconcept heeft zich echter pas over de gehele samenleving verspreid via de veranderingen in het arbeidsproces die samenvattend beschreven worden als de industriële revolutie (Landes, 1983; Pieterson, 1981).

Arbeid is dan ook een extreem voorbeeld van een activiteit die strikt temporeel is gereguleerd. De verwachte duur van de arbeid staat vast en ook de tijdstippen wararop arbeid plaats dient te vinden zijn formeel, vaak op de minuut precies geregeld. Afwijkingen van de 
temporele regels zijn weliswaar mogelijk doch moeten dan wel als uitzonderlijk worden besschouwd en gewaardeerd. In het algemeen kan worden gesteld dat arbeid wordt betaald op basis van de tijd die eraan is besteed en minder op basis van de verrichte taak. Het uurloon buiten de vastgestelde, normale werktijden is, met name in het weekend, hoger dan het gewone uurloon. Ook andere, minder formele activiteiten zijn met strikte temporele verwachtingen verbonden. Rinkelende telefoontoestellen om 2 uur 's nachts, theaterwoorstellingen die een kwartier duren, mensen die elke dag een poosje op de hoek van de straat staan zijn opvallende verschijnselen die vragen om een verklaring omdat ze niet passen in de werwachtingen van normale duur, tijdstip of frequentie.

Pronovost (1989) stelt dat de uniformiteit in de structuur gesuggereerd door de klok en de kallender slechts een illusie is. De sociologie van de tijd heeft als object van studie de verschillende sociale tijden (werktijd, schooltijd, familietijd, wrije tijd), de variaties in temporeel handelen en referentiepunten in het dagelijks leven alsmede de variaties in betekenissen en concepten van tijd tussen mensen uit verschillende leeftijdsgroepen, sociale klassen of levensfasen. Gedeeltes van de dag, stukken tijd, ontlenen hun betekenis volgens Pronovosit aan de activiteiten die erin plaatsvinden. Arbeid is de centrale activiteit walarom heen het dagelijks leven en de betekenissen van het handelen zijn gestructureerd. De mathematische tijd, bijwoorbeeld de periode van 3 uur 's middags tot 4 uur' 's middags heeft op zich geen sociale betekenis.

Echter, wanneer een illusie het handelen van (bijna alle) sociale actoren bepaalt, is ze een sociale realiteit. Daarom mag worden gesteld dat de temporele regelmatigheden weerspiegeld in de klok, de kalender en de agenda, fundamentele aspecten van de sociale structuur zijn. Ze liggen ten grondslag aan de betekenis die aan het handelen wordt gegeven en aan de beoordeling van dat handelen als normaal of afwijkend.

Elchardus en van Rossem (1985) tonen aan dat de evaluatie en motivatie die sociale actoren aan hun handelen geven relatief onafhankelijk zijn van de objectief waarneembare activiteit. Controlerend voor activiteiten vinden zij regelmaten, met kloktijd variërende patronen, in de sociale betekenissen die actoren aan hun handelen geven. Reese en Katovitch (1989) behandelen de beoordeling van drinkgedrag als normaal, afwijkend of deviant in het kader van dergelijke temporele referenties. $\mathrm{Zij}$ stellen dat sociale actoren specifieke temporele coördinaten (tijdstip) en parameters (duur en ritme) toepassen in de afbakening van de sociaal bepaalde grenzen tussen normaliteit en deviantie en in de beoordeling van de mate van normaliteit of deviantie van drinkgedrag. Ter illustratie voeren zij (vanuit hun Amerikaanse achtergrond) aan dat dagelijks drinken (frequentie) los van de hoeveelheid of de sociale consequenties ervan alls een sterke indicator voor probleemdrinken zo niet alcoholisme wordt gezien. Hetzelfde geldt voor het drinken op bepaalde tijdstippen zoals bijvoorbeeld 's ochtend. Ook dit wordt als een voldoende voorwatrde om van alcoholisme te spreken beschouwd. De beoordeling van het gedrag als normaal of deviant varieert met de kloktijd of aan de kalender afgemeten frequenties.

Concluderend kan worden gesteld dat de kloktijd een algemene (door iedereen op gelijke wijze begrepen) en precieze structurerende factor in het dagelijks leven is. Ze maakt coördinatie binnen een zeer complexe samenleving mogelijk en biedt het individu een hoogst betrouwbare cognitieve orde en dus zekerheid.

De temporele structuur lijkt door haar abstract mathematische karakter los te staan van het menselijk handelen. Echter ook de socio-temporele orde is conventioneel van aard. Ze bestaat omdat mensen hun best doen om op tijd te komen en het erover eens zijn 'dat iets 
nu wel lang genoeg gedurd heeft: Het algemene karakter van de socio-temporele orde zorgt voor een grote uniformiteit in sociaal gedrag. Echter, evenals binnen andere ordeningssytemen zal de wijze waarop met deze structuur wordt omgegaan verschillen tussen jongeren en ouderen, marinen en vrouwen, huisartsen en patiënten, leraren en leerlingen of geheelonthouders en alcoholisten.

$\mathrm{Na}$ deze algemene uiteenzetting over de verhouding tussen het handelen van sociale actoren en de sociale structuur en de beschrijwing van het temporele karakter van de structur zal nu in gegaan worden op het aandachtsgebied van de studie: het dagelijks leven. In de volgende paragrafen zal worden beschreven hoe het dagelijks leven kan worden beschouwd. Zowel de optiek van de observator, de sociale wetenschapper, als die van het handelend individu komen aan de orde. Vanuit deze beschrijving zal verder worden ingegaan op de basis van gelijkvormigheden en variaties in gedrag.

\subsection{Het dagelijks leven}

De complexe realiteit van het dagelijks leven kan op verschillende manieren worden benaderd. Ze kan worden opgevat als een stroom van gedrag ( $\AA$ s, 1978). Omdat alle gedrag in een context plaatsvindt kan het dagelijks leven ook worden beschouwd als een stroom van contexten. De eerste optiek is die van de waarnemer, bijvoorbeeld de sociale wetenschapper die het dagelijks leven tracht te beschrijven. De tweede optiek is die van het handelend individu, de sociale actor die het dagelijks leven elke dag opnieuw in moet vullen met gedrag. Beide optieken zullen in het hiernavolgende worden uitgewerkt.

\subsubsection{Het dagelijks leven beschouwd}

Om het dagelijks leven te kunnen beschrijven moet de stroom van gedrag worden onderverdeeld in elementen. De mogelijke specificiteit van de onderverdeling is bijna onbegrensd, elke oogopslag of beweging van een vinger kan als een eenheid van gedrag worden beschouwd.

Ås (1978) noemt activiteiten als eenheden van gedrag en tijd als basisdimensie waarop gedrag plaatsvindt. Van activiteiten kan alleen sprake zijn wanneer begin-en eindpunten van deze gedragseenheden op een tijdschaal kunnen worden gelokaliseerd. Activiteiten zijn stukjes tijd.

Activiteiten kunnen verder worden onderverdeeld in kleinere elementen van gedrag. De kleinste gedragseenheid is de handeling (act). Aan handelingen kan in tegenstelling tot activiteiten geen betekenis worden toegekend zonder het handelend individu en zijn/haar directe omgeving in ogenschouw te nemen. De grens tussen activiteiten en handelingen is niet strikt en absoluut, ze wordt bepaald door de mate van zekerheid waarmee aan een gedrag een betekenis kan worden toegeschreven. Hoe kleiner de gedragseenheid hoe minder zeker de betekenis die eraan kan worden toegeschreven. In dit proefschrift staat het gebruik van alcoholhoudende dranken centraal. Eenheden van gedrag specifieker dan het drinken zelf zoals de wijze van vastpakken van een glas of de grootte van de slokken, zijn voor deze studie niet interessant. Op zulke elementaire eenheden van gedrag wordt dan ook niet ingegaan. 
Ten aanzien wan drinkgedrag kan de vraag worden gesteld of het een activiteit of een handeling is. Is het drinken een eenheid van gedrag die op zich begrepen kan worden of is de betekenis wan dergelijk gedrag alleen te begrijpen in het kader waarin het plaatsvindt.

Hoewel het zeker mogelijk is om begin- en eindpunten van het drinken op een tijdschaal vast te stellen is het meestal niet mogelijk om de betekenis van drinkgedrag vast te stellen zonder te refereren naar de omstandigheden waarin het plaatsvindt. Dat betekent niet dat drinkgedrag betekenisloos is. De betekenis kan echter pas met enige zekerheid worden vastgesteld door de context warin het platswindt en de kenmerken van de drinker en diens directe omgeving in de besehouwing te betrekken. De activiteiten waarbij wordt gedronken bepalen mede de betekenis en beoordeling van het drankgebruik. Reese en Katovitch (1989) beschouwen drinkgedrag als een "act" een handeling. Zij stellen dat temporele omstandigheden de mate waarin het drinkgedrag als deviant of abnormaal beoordeeld wordt samenhangen. Drinken is meestal een handeling en geen activiteit (Weiss, 1985).

De stelling dat drinkgedrag een handeling is en geen activiteit impliceert dat registratie van drankgebruik op zijn minst onvolledig is wanneer de omstandigheden waarin het plaatsvindt daarin niet wordien betrokken.

De benadering van het dagelijks leven zoals beschreven in deze paragraaf is die van de sociale wetenschapper met speciale aandacht voor waarneembaar gedrag. In hoofdstuk 2 wordt methoden om gedrag in het dagelijks leven te registreren beschreven en zal worden ingegaan op de manier waarop drinkgedrag daarin past.

Door een waarnemer kan alleen het concrete gedrag worden geregistreerd. Het onderscheid tussen activiteiten en tussen activiteiten en handelingen is op basis van uitsluitend waargenomen gedrag, zeer moeilijk te maken. Ås (1978) suggereert dat een betere manier om het dagelijks leven in stukjes te verdelen is om uit te gaan van de situaties waarin sociale actoren participeren. Een dergelijke benadering sluit ook beter aan op de wijze waarop sociale actoren hun dagelijks leven ervaren. In de nu volgende paragraaf wordt beschreven op welke wijze sociale actoren hun gedrag afstemmen op de situaties waarin ze participeren.

\subsubsection{Het dagelijks leven beleefd}

Vanuit de sociale actor kan het dagelijks leven worden beschouwd als een reeks van contexten of situaties die elke dag opnieuw moeten worden ingevuld. Gerhardt (1971) geeft een omschrijving van het proces van afstemming van het gedrag op de situátie. Sociale actoren stemmen hun gedrag af op de actuele situatie, de handelingsruimte. Hierdoor zijn ze verzekerd van een relatief teleurstellingsvrije reactie. Ze kunnen er redelijk zeker van zijn dat er op hun gedrag gereageerd zal worden zoals zij verwachten.

De afstemming van het gedrag op de situatie doorloopt grofweg drie fasen:

1) waarneming van de gedragsruimte

2) interpretatie van beperkingen en mogelijkheden

3) selectie wan de adequaat geachte gedragsstrategie

In dit actieve proces vereenvoudigt het individu verschillende aspecten van de waargenomen werkelijkheid, de objecten in de situatie, tot ideaal-typen, abstracties. Alleen zo is het mogelijk om de gegevens een typische (dat wil zeggen niet unieke) betekenis toe te kennen, te duiden. De aard van de objecten kan variëren. Het kunnen fysieke objecten zijn maar ook 
sociale: gebodsborden, personen, verwachtingen, gelaatsuitdrukkingen enzovoort. Dit proces van duiding is de interpretatie van de situatie in wat Gerhardt noemt 'Deutungsschemata'. 'Deutungsschemata komen durch abstraktion zustande, sie sind idealisierende Typisierungen in Termini van Handlungsregeln' (Gerhardt, 1971).

Sociale actoren vertalen de concrete, actuele situatie in 'standaard' richtlijnen voor gedrag. De waargenomen mogelijkheden, verwachtingen, de van toepassing zijnde regels worden door de sociale actor bewust meegenomen in het beeld van hoe hij/zij zich, gegeven de situatie zou moeten gedragen. Dit beeld is de handelingsoriëntatie. Hel praktische bewustzign van het individu in de situatie bestaat uit de kennis van de regels en tactieken waardoor het sociale leven wordt geconstitueerd en gereconstitueerd (Giddens, 1984). Sociale actoren kunnen zich hieromtrent vergissen. Ze kunnen het geheel wan regels fout interpreteren of waarnemen. Dit kan resulteren in ongepast gedrag: 'situational improperties'. Echter 'if there is any continuity to social life at all, most actors must be right most of the time; that is to say they know what they are doing and they succesfully communicate this knowledge to others' (Giddens,1984). Wanneer mensen zich doorlopend vergissen worden ze doorgaans als afwijkend, zo niet als gek betiteld. 'Madness is a cluster of situational improperties'.

De meeste mensen gedragen zich dus het merendeel van de tijd op een wijze die past binnen de sociale structuur waar ze deel van uitmaken. Verschillen in gedrag kunnen worden verklaard uit verschillen in handelingsoriëntatie. Dergelijke verschillen gaan onder andere samen met verschillen in de situatie waarin sociale actoren zich bevinden. Wilks en Callan (1989) onderzoeken de beoordeling door jonge mannen en vrouwen van drinkgedrang in verschillende situaties als zijnde gepast of ongepast. Dit oordeel vergelijkt hij met dat van hun ouders en beste vrienden. Jonge mannen en vrouwen stemmen overeen met ouders en vrienden in de rangschikking van situaties naar de gepastheid van drinkgedrag in die situaties. In feestelijke en gezellige situaties (recepties, verjaardagen, Nieuwjaar) wordt drankgebruik gepaster geacht dan in situaties als televisiekijken, het bezoeken van sportwedstrijden of bij een vriend die in de put zit. Er zijn wèl verschillen in de mate waarin jonge mannen en vrouwen, ouders en vrienden drinken in die situaties gepast achten. Jonge mannen in het bijzonder, beoordelen alcoholgebruik in alle situaties, meer als gepast dan hun ouders.

De aanname dat sociale actoren bewust handelende wezens zijn die hun gedrag afstemmen op de concrete handelingsruimte, is wel noodzakelijk maar niet voldoende om regelmatigheden in gedrag te kunnen verklaren. De veronderstelde kennis van de sociale regels en verwachtingen alsmede de sancties bij overtreding daarvan verklaart dat sociale structuren kunnen blijven bestaan, of met andere woorden, steeds worden herschapen. Maar zelfs onder de aanname dat een bestaande sociale structuur absolute grenzen an het gedrag stelt zijn er binnen situaties enorm veel gedragsalternatieven. Indien mensen voor elke mogelijke variatie in gedrag een bewuste keuze zouden moeten maken zouden ze nooit tot enig sociaal gedrag kunnen komen. Het gegeven dat sociale actoren in staat zijn om tot gedragskeuzen te komen en dat deze keuzen zowel binnen individuen als tussen individuen grote regelmaat vertonen vraagt dan ook om een nadere verklaring. Een beschrijving van gedrag als gewoonte kan zo'n verklaring bieden. 


\subsection{Gewoonten}

Een gront deel van het dagelifks handelen is onbewust, relatief ongemotiveerd en bijna automatisch. Dit deel van het gedrag kan omschrewen worden als routine of gewoonte. Young (1988) stelt dat het vermogen om gewoonten aan te leren besloten ligt in de menselijke genen. Dit vermogen wordt benut omdat het alleen door gewoonten mogelijk is om te handelen zonder voortdurend te moeten kiezen en te worden geconfronteerd met de onzekerheid die met het maken van ketuzes gepaard gat. Zonder steeds opnieuw in het geheugen te moelen zoeken naar eerdere, vergelijkbare situaties en hergeen daarin platsvond. Gewoontes fungeren als energiebesparende gedragsmechanismen, potentiele kant-en-klare responsiepatronen op bepaalde prikkels (o.a. sociale stimuli in sociale situaties)' (Gadourek, 1963).

Gewoonten moeten worden geleerd en geoefend. Handelingen die in eerste instantie veel concentratie vergen en moeite kosten, kunnen wanneer de gewoonte eenmaal verworven is met een wardigheid uitgevoerd worden die bewust handelend niet mogelijk zou zijn. De ervaren automobilist hoeft niet meer bij elke bocht of ieder stoplicht na te denken over de volgorde en manier wan koppelen, remmen en schakelen en kan daarom op overstekende kinderen of honden en afwijkende gedrag van andere automobilisten letten. Doordat een groot deel wan het handelen aan de gewoonte kan worden overgelaten bliff er ruimte in het bewustzijn voor het nieuwe, het onverwachte.

De gewoonte als aangeleerd, semi-automatisch gedragsmechanisme kan verklaren waarom een individu in gelijksoortige omstandigheden op vergelijkbare wijze zal reageren. Regelmatigheden in gedrag tussen individuen zijn daarmee echter nog niet verklaard.

Gadourek (1963) onderscheidt individuele gewoonten en sociale gewoonten. Als individuele gewoonten beschouwt hij de gedragspatronen zoals hierboven beschreven. Sociale gewoonten ontstaan als gevolg van het menselijke vermogen om te leren van anderen, om bestaande gedragspatronen van anderen over te nemen. Het aanleren van adequate gedragspatronen door 'trial and error' zou de mogelijke ontwikkeling van het individu sterk reduceren. Het is dan ook veel efficiènter om de gewoonten van anderen over te nemen. Niet alle gedrag dat gelleerd is van anderen, is een sociale gewoonte. Kenmerkend voor sociale gewoonten is dat ze bijna onbewust van anderen worden overgenomen. Belangrijk is dat de gewoonte een relatief ongemotiveerd gedrag is. Ze ontstaat omdat het gedragspatroon een bepaald 'nut' heeft, terecht of ten onrechte als een adequate respons op bepaalde stimuli wordt beschouwd. Eenmal tot gewoonte geworden is dat 'nut' echter geen motiwatie meer woor het gectragspatioon. De gewoonte motiveert zichzelf. Het is dus mogelijk dat het gedrag waruit de gewoonte bestaat zijn nut verloren heef. Bewust handelende actoren kunnen hun gewoonten veranderen.. Mensen kunnen gewoonten echter ook dusdanig goed geleerd hebben dat ze er zelfs wanneer ze volledig nutteloos geworden zijn, nog gebruik wan maken. Mensen kunnen opgesloten zitten in hun automatische gedragspatronen. Bij het overnemen van gewoonten van anderen behoeft de oorspronkelijke motivatie erwoor niet ook te worden overgenomen. Daarom zijn gewoonten conservatieve elementen van de sociale structuur, voortzettingen van de verworvenheden uit het werleden in het heden: "habit is the flywheel of society" (Young, 1988).

De grens tussen socialle gewoonten en individuele gewoonten is niet zeer scherp temeer daar elke sociale gewoonte ook een individuele gewoonte is (marr niet vice wersa). Gadourek (1963) stelt dat 'de sociale gewoonte door herhaling en oefening, door de koppeling wan 
talrijke plezierige, bijkomstige ervaringen die de adequate responsie in de sociale situatie meebrengt tot de gewoonte van het individu wordt, vaak even diep geworteld in zijn responsie- en reactiesysteem als de gestes of verbale uitdrukkingen, die hij individueel, door zoeken en tasten heeft verworven".

Gadourek rekent ook drinkgedrag tot de categorie der gewoonten. Hij onderscheidt de individuele drinkgewoonten en de sociale drinkgewoonten. De situaties waarin het in een bepaalde samenleving gepast geacht wordt alcohol te gebruiken reflecteren de sociale drinkgewoonten. De mate waarin sociale actoren ook werkelijk in dergelijke situaties drinken, de gedronken hoeveelheden of de snelheid waarmee ze hun glas ledigen kunnen uitingen zijn van individuele gewoonten. Ook regelmatig drinken in een situatie waarin dai ongepast geacht wordt moet als een individuele drinkgewoonte worden beschouwd. Het nut van drinkgedrag (de reden waarom het een sociale gewoonte kan worden) kan worden gezocht in de fysiologische en psychologische effecten van alcohol en in de (daaruit voortvloeiende) sociale betekenissen van het gebruik. Omdat normaal drinkgedrag vaak een gewoonte is behoeft het echter niet steeds te worden gemotiveerd (Weiss, 1985). Er wordt in bepaalde omstandigheden gedronken omdat dat altijd al zo is geweest of ondat iedereen dat doet.

Natuurlijk is drinkgedrag niet zomaar een gedrag. Het is een gedrag dat zekere risico's met zich meebrengt. Sociologisch gezien is het riskante van drinkgedrag dat de individuele drinkgewoonten een dusdanige plats in het dagelijks leven in kunnen nemen dat ze het sociale functioneren van de drinker kunnen verstoren, zodanig ernstig dat de vervulling van sociale verwachtingen erdoor in het gedrang kan komen (Philipsen, 1976).

De manier waarop beelden van typisch handelen tot stand komen, de wijze van abstractie komt voort uit en vindt zijn weerslag in de bestaande sociale structuur. Regelmatigheden in gedrag kunnen worden begrepen door aan te nemen dat sociale actoren wisselende omstandigheden als gelijke typen situaties interpreteren. Vanuit de kennis van de sociale structuur kan worden begrepen welke aspecten in contexten als gelijksoortig zullen worden geïnterpreteerd. In de paragraaf $\mathbf{1 . 3}$ is uiteengezet dat de sociale structuur in onze samenleving een belangrijke temporele dimensie heeft. Aangenomen mag worden dat temporele aspecten van de concrete actuele context mede bepalend zijn voor de interpretatie van die context als een bepaald type situatie en dus voor de keuze van gedragsalternatieven. Niet alleen verschillen in situaties liggen ten grondslag aan verschillen in gedrag. Ook systematische verschillen in handelingsoriëntatie verbonden met kenmerken van de sociale actor kunnen variaties in gedrag verklaren. Verwachtingen ten alanzien van personem met bepaalde kenmerken, in bepaalde posities of situaties worden omschreven als rollen.

\subsection{Rollen}

De systematische varhaties in de verwachtingen ten aanzien van gedrag die samengaan met kenmerken van het handelend individu of zijn/haar relatie tot anderen, worden omsclureven als rollen. 'Rolles are socially defined expectations which a person in" a given status or social position follows' (Giddens, 1984). 
Gerhardt onderscheidt drie typen rollen:

1) Statusrollen

2) Positierollen

3) Situatierollen

De status is hetzelfde als de sociale identiteit wan een persoon. Deze is gebaseerd op geslacht. leeftijd, ras, sociale klasse of andere toegeschreven of geèrfde kenmerken die een persoon bezit, voor zover ze voor de sociale wardering wan individuen belangrijk zijn (Blokwan der Voort; 1978). Verschillen in sociale identiteit op basis van geslacht en leeftijd komen in alle bekemde samenlevingen voot, de concrete inhoud van die verschillen varieert per samenleving. De 'ascribed' of toegeschreven verwachtingen die samengaan met zulke kenmerken vormen de statusrol. In onze samenleving zijn de verwachtingen gebonden aan status tamelijk abstract. De statusrol is de meest abstracte rol. Daarbij zijn statusrollen sterk geinstitutionaliseend, dat wil zeggen de verwachtingen worden door een zeer groot deel van de populatie gedeeld en veranderen niet of nauwelijks in de loop van de tijd. Hoewel algemeen, biedt de statusrol weinig ruimte voor individuele interpretatie van de eraan verbonden verwachtingen.

Posities zijn platatsen binnen sociale deelsystemen (werkverband, gezinsverband, vereniging en dergelijke). Actoren bezetten posities en zijn daarmee gepositioneerd ten opzichte wan hun sociale omgeving. Een persoon kan verschillende posities tegelijkertijd innemen. Als werknemer binnen een werkverband, als vader en echtgenoot binnen het gezinswerband en als voorzitter van de woetbalwereniging binnen het clubverband. De verwachtingen waruit positierollen bestaan zijn minder abstract dan die van de statusrollen. Vaak zijn ze zelfs formeel vastgesteld in reglementen (zoals bijvoorbeeld voor rijksambtenaren in het Algemeen Rijksambtenaren reglement: ARAR). De verwachtingen bestaan grotencleels uit aanspraken op het individu die met een zekere regelmaat moeten worden nagekomen. Met andere woorden de verwachtingen zijn van een duurzaam karakter. In tegenstelling tot de status is de positie verworven. Eenmaal in een positie moet de socialle actor deze positie waarmaken door de positierol adequat te vervullen. Wat een adequate vervulling is varieert per positierol. Op korte termijn -de dag en de week- wordt het dagelijks leven door positierallen gestructureerd. Ze veronderstellen, wil een persoon zijn/haar positie behouden, een regelmaat in activiteiten en daarmee een vaste duur en vaste tijdstippen voor die activiteiten.

Situatierollen bestaan uit verwachtingen van gepast gedrag in situaties. De situatierol heeft geen duurzaam karakter. Ze is enkel 'geldig' binnen een in de tijd en ruimte afgebakende concrete situatie. De aspecten van de situatie die in de definitie van de situatierol worden betrokken bepalen in hoeverre deze rol diffuus dan wel specifiek is.

Specifieke situatierollen zijn 'zaakgeorie̋nteerd", ze bestaan uit specifieke verwachtingen. Een voorbeeld van een specifieke situatierol is die van verkeersdeelnemer. De verwachtingen waruit deze rol bestatat hebben betrekking op de objectieve, zakelijke omstandigheden en zujn ook alleen in die omstandigheden van toepassing (het verkeer). De verwachtingen zijn nauw omschreven en bieden weinig of geen mogelijkheden om elementen van de status, positie of persoonlijkheid tot uitdrukking te brengen. Een rood stoplicht betekent voor alle automobilisten 'stop" of het nu jonge mannen zijn of oudere vrouwen.

Als de verwachtingen meer zijn gericht op de relaties ten opzichte wan anderen is de 
situatierol meer diffuus. De relationele aspecten overheersen. Voorbeelden van dergelijke rollen zijn "vriend' of 'gast'. De handelingsoriëntaties werbonden met dergellijke rollen kunnen in allerlei objectieve omstandigheden als adequaat worden gezien.

Kenmerkend voor alle situatierollen is dat ze alleen van toepassing zijn in de in tijd en ruimte afgebakende situatie van het actuele moment. Situatierollen kunnen worden gehanteerd om inzichtelijk te maken waarom verschillende individuen zich binnen bepaalde omstandigheden gelijk gedragen. In dit opzicht zijn ze vergelijkbaar met sociale gewoonten. Ze zijn eveneens vergelijkbaar met sociale gewoonten ondat ze verschillen in gedrag binnen een situatie niet kunnen verklaren. Het verschil tussen situatierollen en sociale gewoonten is dat de rol bestaat uit verwachtingen ten aanzien van gepast gedrag terwijl de gewoonte bestaat uit het gedrag zelf.

Hoe dan ook voor de verklaring van systematische verschillen in gedrag tussen individuen zijin status- en positierollen geschikter dan situatierollen.

Samenhangen tussen rollen en drankgebruik kunnen op twee manieren ontstaan. Op de eerste plaats doordat de status- of positierol de situaties warrin de sociale actor participeert mede bepalen. Met name positierollen bestaan uit verwachtingen die het dagelijks leven structureren. Die bepalen wat iemand wanneer moet doen. Meestal wordt het gebruik van alcohol tijdens het vervullen van positierolverplichtingen (werken naar school gaan of kinderen verzorgen) of vóor het vervullen wan positierollen niet gepast geacht (Knibbe, 1984).

De tweede manier waarop rollen met variaties in drinkgedrag kunnen samenhangen is door middel van variaties in de beoordeling van gepastheid van drinken in een situatie. Uit het onderzoek van Wilks en Callan (1989) blijkt bijvoorbeeld dat ouderen en jongeren, mannen en vrouwen de mate van gepastheid van drankgebruik in gegeven situaties anders beoordelen. Ook van andere rollen kan worden verwacht dat ze met drinkgedrag samenhangen. De relaties tussen rollen en drinkgedrag worden verder onderzocht in hoofdstuk 4 .

\subsection{Conclusies}

In het voorafgaande is het theoretisch kader waarop dit proefschrift berust beschreven. Er zijn theorieën van gedrag gepresenteerd en toegepast op drinkgedrag.

Centraal staat dat drinken wordt beschouwd als een handeling die plaatsvindt in situaties. De kenmerken van de situaties die bepalen of er wordt gedronken zullen voor een deel van temporele aard zijn. De dag van de week, het tijdstip van de dag hebben een dusdanig sterke verbinding met het sociale leven dat ze waarschijnlijk ook met drinkgedrag samen zullen hangen. Behalve de tijd mag ook de activiteit als definièrend kenmerk van situaties worden beschouwd. Het zijn deze twee aspecten van situaties die in hoofdstuk 3 worden gebruikt om de sociale drinkgewoonten in Nederland te omschrijven.

Gewoonten zijn gedragspatronen. Ze ontstaan vanuit de noodzakelijkheid om een deel van het dagelijks gedrag min of meer automatisch te verrichten. Mensen hebben het vermogen om gewoonten te leren en om ze van anderen over te nemen, af te kijken. De met anderen gedeelde gewoonten zijn sociale gewoonten. Hoewel de oorsprong van een bepaaide gewoonte moet worden gezocht in het nut van het betreffende gedragspatroon is kenmerkend voor de gewoonte dat ze relatief ongemotiveerd is. De sociale gewoonte wordt 
uitgevoerd omdat ze een gewoonte is, omdat de uitwoerder ervan geleerd heeft om haar uit te voeren als reactie op sociale stimuli in een sociale situaties. Tussen de stimulus in de situatie en de respons, de sociale of individuele gewoonte stat het bewste handelende individu. De relatie is niet deterministisch. Het individu kan er voor kiezen om een gewoonte wel of niet uit te woeren.

of drankgebruik in een bepaalde situatie als gepast wordt beschouwd ligt besloten in de situatierol, de min of meer vaste verwachtingen van gedrag in die situatie. Omdat de meeste mensen het merendeel van de tijed handelen volgens de geldende verwachtingen mag worden aangenomen dat het daadwerkelijk gedrag reflecteert welke situatierollen drinkgedrag omvatten.

Drinken in een bepaalde situatie mag alleen als een sociale gewoonte worden beschouwd als het met een zekere regelmat in het dagelijks leven voorkomt. Per definitie is een gewoonte normaal gedrag. Niet alle sociale gewoonten komen even vaak voor. Aangenomen wordt dat de normaliteit van een sociale gewoonte samenhangt met de mate waarin het betreffende gedrag zich in het dagelijks leven voordoet. Uit de empirische kans op drinkgedrag in een situatie kan worden afgeleid in welke mate drinken in die situatie als gepast mag worden beschouwd.

Positie- en statusrollen bepalen voor een deel in welke situaties sociale actoren in het dagelijks leven verkeren. Daarmee bepalen ze ook voor een deel de mogelijkheid om te drinken. Een tweede manier waarop rollen met consumptie kunnen samenhangen is door middel van de intensiteil van het drinkgedrag in situaties. Aangenomen wordt dat systematische verschillen in drinkgedrag in een gegeven situatie tussen actoren met verschillende rollen, met die rollen verbonden verschillen in de beoordeling van de gepastheid van drinken in die situatie reflecteren.

Drinkgedrag is een riskant gedrag. Het drinkgedrag kan een grote invloed hebben op het sociale functioneren van individuen. Wanneer drinkgedrag de vervulling van sociale verplichtingen verbonden met positierollen, onmogelijk maakt is er sprake van verslaving in de sociologische betekenis van het woord (Philipsen, 1976). Verschillen tussen mensen die veel en weinig drinken kunnen worden geinterpreteerd als aanwijzingen omtrent het proces van intensivering van drinkgedrag. Behalve een beschrijving van de sociale drinkgewoonten in Nederland en de variaties in drinkgedrag verbonden met positie- en statusrollen zullen ook verschillen tussen lichte en zware drinkers in dit proefschrift worden onderzocht. 


\section{Hoofdstuk 2 \\ Tijdbesteding en alcoholgebruik: registratie methoden en data}

\subsection{Inleiding}

In dit hoofdstuk wordt beschreven welke onderzoeksinstrumenten in deze studie zijn gebruikt. De situaties waarin mensen verkeren zijn belangrijke determinanten voor hun gedrag, dus ook voor hun drankgebruik. Naast de aanwezige personen, de lokatie en de bezigheid spelen temporele aspecten van situaties hierin een belangrijke rol. Zoals hiervoor werd betoogd kan het dagelijks leven worden gezien als een reeks van wisselende situaties. In die situaties kan in meerdere of mindere mate drankgebruik plaatsvinden. Omdat een beschrijving van de wijze waarop drinkgedrag samenhangt met de verschillende aspecten van de situaties inzicht kan verschaffen in de regels omtrent dat gebruik, is het noodzakelijk om het dagelijks leven als geheel van situaties te bestuderen. Niet alleen omstandigheden waaronder drankgebruik platsvindt, maar ook die walaronder niet gedronken wordt zijn van belang. Alleen door tijdbestedingsonderzoek kunnen dergelijke vragen worden onderzocht. In paragraaf 2.2 worden verschillende vormen van tijdbestedingsonderzoek beschreven. Op grond hiervan wordt aangegeven welke methode van onderzoek geschikt lijkt.

In tijdbestedingsonderzoek wordt meestal geen aandacht geschonken aan drinkgedrag (Simpura, 1985). De sterke en zwakke kanten van instrumenten ter meting van drankgebruik worden beschreven in paragraaf 2.3. Hierbij zal bijzondere aandacht worden geschonken aan instrumenten die passen in tijdbestedingsonderzoek. In paragraaf 2.4 wordt het instr ment dat in deze studie is gebruikt, beschreven. Ook de steekproef en de onderzoekspopulatie zullen in deze paragraaf kort worden behandeld. Dit hoofdstuk wordt afgesloten met cen paragraaf waarin verschillende analyse-eenheden, meeteenheden en mogelijke maten die worden gebruikt bij dagboekmateriaal worden beschreven. 


\subsection{Tijdbestedingsonderzoek}

Het tijdbestedings of time-budget onderzoek is geinspireerd op economisch en sociaalwetenschappelijk onderzoek naar de wijze waarop mensen (of huishoudens) hun geld verdienen en besteden. Dit socio-economisch gedrag van mensen werd en wordt als een nuttige bron van kwantitatieve informatie over het dagelijks leven gezien (Szalai, 1984). Een tijdsbudget besclirift hoe mensen hun tijd besteden. Omdat er ook activiteiten zijn die geen geld opbrengen of kosten, geeft de wijze warop mensen hun tijd besteden een vollediger beeld van het dagelijks leven dan de wijze warop ze hun geld verdienen en besteden.

Kenmerkend voor de tijdbesteding is dat geen enkel mens, hoe rijk, arm, dom of slim dan ook, per dag meer tijd te besteden heeft dan een ander. Variaties in tijdbesteding tussen personen berusten dus uitsluitend op het verruilen van tijd besteed aan de ene activiteit met die besteed an een andere (Converse $e_{y} 1968$ ).

In het licht van het algemene onderzoeksprobleem zoals geformuleerd in hoofdstuk 1 , heeft tijdbestedingsondlerzoek meer aantrekkelijke kanten. Het biedt de gelegenheid om alledaags, normaal gedrag te observeren en te meten met een maat (de tijd) die eigenschappen van ratio-niveau heeft. Daarnaast kan de tijdbesteding worden gezien als gedragsindicator van waarden en preferenties. Verder geeft de tijdbesteding een beeld van de sociale actor in de totaliteit van alle rollen die hij in het dagelijks leven vervult. Tijdbestedingsonderzoek is veelomvattend maar daardoor bijna noodzakelijk ook oppervlakkig. In principe staan dit type onderzoek drie methoden ter beschikking: observaties, vragenlijsten en dagboeken.

\subsubsection{Observaties}

Observatiles van tijdbesteding kunnen plaatsvinden door middel van de participerende methode, via leden wan de huishouding van betrokkenen of registrerende media zoals videocamera"s (Robinson, 1988). In vergelijking tot vragenlijsten en dagboeken vormen zulke observatie studies de meest objectieve methode om tijdbesteding te registreren.

Een praktisch nadeel van observatiestudies is dat de omvang van de onderzoekspopulatie beperkt zall zijn door de hoge kosten en grote tijdsinvestering die een continue directe of indirecte observatie met zich meebrengt. Naast hoge kosten hebben observaties als nadee], dat een storencle invloed op het te observeren gedrag kan uitgaan van de constante an wezigheid van een (al dan niet elektronische) observator. Problemen van een geheel andere orde betreffen het indelen van waargenomen gedrag in categorieèn van activiteiten en de interpretatie van de wargenomen activiteit door de observator (zit iemand te slapen of na te denken?).

\subsubsection{Vragenlijsten}

Vragenlijsten die worden gebruikt bij tijdbestedingsonderzoek zijn de zogenaamde 'activity. checklists. Aan de hand van een uitputtende lijst van activiteiten worden respondenten ondervraagd over frequentie wan deelname en bestede tijd per activiteit. De duur van interviews is aanzienlijk geringer dan die van observaties waardoor bij gelijke investering grotere groepen respondenten kunnen worden ondervraagd.

Om een goede indruk van de tijdbesteding te krijgen zullen activiteiten zeer specifiek moeten worden omschreven. Dit heeft tot gevolg dat de vragenlijsten erg lang worden. Ex 
kan niet naar veel extra informatie per activiteit worden gevraagd. De betrouwbatarheid van de gegevens verkregen door vragenlijsten is groter naarmate de periode wartover moet worden gerapporteerd korter is en deze periode recenter is. Een rapportage van lhet gedrag in een recente korte periode (gisteren) zal echter vaak niet representatief zijn voor het 'doorsnee' gedrag van een individu.

Met uitzondering van duidelijk gedefinieerde en regelmatig voorkomende activiteiten (bijwoorbeeld werk) is de vragenijist methode geen valide meetmethode voor tijdbesteding. De tijd besteed aan minder gestructureerde, onregelmatige of kortdurende activiteiten, zoals huishoudelijk werk, televisiekijken of kinderverzorging, wordt door de zogenaamde gestileerde methoden overschat (Robinson, 1985).

\subsubsection{Dagboeken}

Aangenomen wordt (Juster, 1985) dat de dagboekmethode de enige praktisch toepasbare methode is waarmee bij grote onderzoekspopulaties valide data over tijdbesteding kunnen worden verzameld. Het dagboek is een instrument warmee mensen gedurende een bepaalde periode op een betrouwbare wijze duur, tijdstippen en volgorde van hun activiteiten vast leggen.

De dagboekmethode kan gezien worden als hét voorbeeld van een 'micro-behavioral' benadering van survey-onderzoek. Deze benadering onderkent de beperkte vermogens van respondenten om complex gedrag te rapporteren. Vragen worden beperkt tot elementaire ervaringen waarover respondenten wel accuraat kunnen rapporteren (Robinson, 1988).

De tijd tussen het registreren van het gedrag en dat gedrag zelf is maximaal 1 dag maar meestal minder. Geheugenproblemen worden daardoor geminimaliseerd. In dagboeken wordt gebruik gemaakt van een kader voor gedrag (kloktijd) waarvan aangenomen mag worden dat het door alle respondenten op dezelfde wijze wordt begrepen en dat deze interpretatie overeenstemt met de wijze waarop ze door de onderzoeker is bedoeld.

Een groot voordeel van gegevens verkregen door middel van dagboekonderzoek is dat er verschillende analyse-eenheden kunnen worden gekozen: respondenten, activiteiten en tijdseenheden. De multi-dimensionaliteit compliceert echter wel het verwerken van gegevens verkregen door dagboeken. Gegevens van dagboeken komen overeen met gegevens van andere, duurdere, methoden om tijdbesteding te meten. De uitkomsten van dagboekonderzoek correleren zeer sterk (meestal .80 of hoger, vaak zelfs .90) met die van observatie-studies en methoden van 'event sampling' (Robinson, 1985). Bij deze laatste methode dragen respondenten gedurende een of meer dagen een pieper bij zich. De pieper zendt 'at random' een signaal uit. Bij ieder signaal moeten respondenten registreren wat ze op dat moment doen (en eventueel aanvullende informatie geven) (deVries, 1987). Hill (1985) vindt een correlatie van .95 tussen het dagelijks patroon in gebruik van elektrische apparaten gebaseerd op dagboekgegevens en dat gebaseerd op de gegevens van elektriciteitsmeters. De criterium validiteit van dagboekgegevens is hoog.

De resultaten van dagboekonderzoek passen binnen gangbare theorieën over sociaal gedrag. Zo blijken jongeren in vergelijking tot ouderen meer tijd te besteden aan activiteiten gericht op de toekomst (investering) en minder aan activiteiten gericht op het heden (consumptie). Ook kan een groter deel van de variaties in tijdbesteding worden verklaard voor mannen dan voor vrouwen, een gegeven dat past binnen de theorie dat het dagelijks leven wan mannen gestructureerder is dan dat van wrouwen (Juster, 1985). Deze uitkomsten geven aan dat ook 
de construct validiteit van dagboekgegevens hoog is. Evenzo is er sprake van een hoge betrouwbarheid van dagboekgegevens. De vergelijkbarheid van schatuingen van tijdbesteding op geaggregeerd niveau bij verschillende populaties (bijwoorbeeld nationaal en lokaal) of op verschillende tijdstippen is zeer groot. Correlaties van 70 of hoger zijn geen uitzondering (Robinson, 1985).

Binnen de dagboekmethode zijn verschillende variaties mogelink, zowel naar gedetailleerdheid als naar gefixeerdheid van gegevens. Scheuch (1972) stelt dat de betrouwbarheid en validiteit van tijdbestedingsdata zeer gevoelig zijn voor details in de data-verzamelingmethode. Criteria om de kwaliteit wan verschillende dagboekmethoden te vergelijken kumnen worden afgeleid uit kenmerken van de data zelf zoals het gemiddeld aantal gerapporteerde activiteiten per dag, de variatie in activiteiten per dag, het aantal gerapporteerde secundaire activiteiten per dag en de hoeveetheid niet verantwoorde tijd. Methoden warmee gemiddeld meer (primaire of secundaire) activiteiten worden geregistreerd, methoden die meer variatie in activiteiten registreren en methoden die minder tijd onwerantwoond laten worden betrouwbaarder en geldiger geacht. Scheuch (1972) gebruikt deze criteria zelfs als indicatoren voor de kwaliteit wan het werk van de interview(st)er, als aanwijzingen van eventuele fraude (zelf invullen dagboeken) of nalatigheid bij het coorwagen.

Hier zullen enkele belangrijke vormen van wariaties in de dagboek methode worden besproken:

1) De keuze voor een open dan wel gesloten registratie van activiteiten.

2) De keuze voor een continue dan wel vaste registratie.

3) De keuze betreffende de ciuur van de onderzoeksperiode.

4) De toegevoegde informatie.

\section{Open of gesloten activiteitenregistratie}

De keuze voor een open of gesloten activiteitenregistratie is vergelijkbaar met die voor open of gesloten vragen in enquetes.

Bij een open registratie kunnen respondenten zonder enige resitrictie omschrijven wat ze hebben gedaun. Dit heeft als een mogelijk voordeel dat nieuwe en onverwachte activiteiten in het materiaal op kunnen duiken (Robinson, 1988). Een verder voordeel van de open activiteitenregistratie is dat gegevens, afhankelijk van de (deel)vraagstelling, op verschillende manieren kunnen worden gecodeerd. De methode heeft als nadeel dat respondenten onduidelijke (bijwoorbeeld onleesbaar), vage of heel algemene omschrijvingen van hun activiteiten kunnen geven. Dit is met name een bezwaar wanneer er een zekere specificiteit, bijvoorbeeld bij bijzondere interesse voor bepalde activiteiten, is gewenst. Een praktisch nadeel van open registratie is dat de gegevens door de codeur/onderzoeker in categorieën moeten worden ingedeeld (Stoop en Oudhof, 1988). Dit is niet alleen veel werk, er kunnen hiverbij ook systematische fouten worden gemaakt.

Bij de gesloten registratie moeten respondenten kiezen uit een lijst van activiteiten. In feite neent de respondent de codeerwerkzaamheden van de onderzoeker over. Voordeel hiervan is dat respondenten zelf kunnen aangegeven binnen welke categorie van activiteiten hun gedrag valt en dat de gewenste specificiteit is gegarandeerd. De resultaten van verschillende respondenten of verzameld op verschillende tijdstippen zijn zeer goed vergellikbaar. Een nadeel van gesloten registratie is dat ook respondenten zich bij de registratie kunnen vergissen. Dit laatste is met name het geval wanneer er een groot aantal activiteiten is 
waaruit kan worden gekozen. Knulst en Schoonderwoerd (1983) gebruiken een lijst van maar liefst 226 verschillende activiteiten waaronder meer dan 50 categorieên betreffende leesgedrag (verschillende bladen). In dat geval bestaat het gevaar dat de inhoud wan de lijst waaruit kan worden gekozen de resultaten kan sturen.

Welke methode er ook wordt gebruikt, de onderzoeker zal vooraf of achteraf een indeling van gedrag in categorieën van activiteiten moeten maken. Een dergelijke indeling is altijd een vereenvoudiging van de werkelijkheid die zeer grote consequenties kan hebben voor de resultaten van het onderzoek.

\section{Continue of gefixeerde registratie}

Met continue registratie wordt bedoeld dat respondenten nauwkeurig aangeven op welk tijdstip activiteiten beginnen en eindigen (bijvoorbeeld: van 07.11 uur tot 07.20 uur gewassen en tanden gepoetst). Op grond van deze exacte opgaven wordt berekend hoeveel tijd er aan verschillende activiteiten is besteed. Ook de frequentie wan voorkomen en de wolgorde van activiteiten kan worden vastgesteld. Voor onderzoek natar de timing en frequentie van activiteiten wordt deze methode geprefereerd (Stoop en Oudhof, 1988). Het vermoeden is evenwel gewettigd dat feitelijk door respondenten niet continue wordt geregistreerd. Men registreert een of twee keer per dag of soms zelfs de volgende clag (Yesterday interview) wat men heeft gedaan. Betwijfeld mag worden of de dloor deze methode gesuggereerde nauwkeurigheid van duur en tijdstippen wel serieus mag worden genomen. Daar komt nog bij dat het data-materiaal dat door middel van continue registratie ontstaat zeer complex is. Het aantal variabelen per dag en per respondent kan verschillen.

Gefixeerde registratie betreft een registratie van de belangrijkste activiteit per vastgesteld tijdinterval. Meestal betreft het een registratie per kwartier, soms ook per vijf minuten of per half uur. Bij langere intervallen wordt het moeilijker om eén activiteit als de belangrijkste aan te wijzen. Op deze wijze ontstaat er een zeer gestileerd beeld van het menselijk gedrag (Knulst en Schoonderwoerd, 1983). Activiteiten duren in werkelijkheid meestal niet precies 15 minuten (of 5 minuten of een $1 / 2$ uur) en ze beginnen of eindigen meestal ook niet op het kwartier. Voor onderzoek naar de duur van activiteiten (per dag, week) verdient deze methode de voorkeur boven de continue registratie (Stoop en Oudhof, 1988). Ook ten aanzien van timing en frequentie is een registratie per kwartier waarschijnlijk specifiek genoeg om betrouwbare informatie te garanderen. Bovendien is de verwerking wan data verzameld volgens de gestileerde methode eenwoudiger.

\section{De duur van de onderzoeksperiode}

De periode van waarnemingen ligt bij dagboekonderzoek meestal tussen éen dag en éen week. Stoop en Oudhof (1988) suggereren dat bij een langere duur van registratie de kwaliteit van de data achteruit zou gaan. $\mathrm{Zij}$ kunnen daar echter geen empirisch bewijs voor vinden.

Een mogelijk nadeel van een dagboek over langere periodes (bijwoorbeeld een week) is dat de belasting van de respondent zo groot wordt dat deze gevolgen voor de respons gaat krijgen. Met name mensen die het 'druk' hebben zullen niet mee willen werken terwijl een dergelijk kenmerk nu net een punt van interesse is.

Voordeel van gegevens over verschillende dagen is dat verbanden tussen het gedrag op 
vergchillende dagen kunnen warden onderzocht. Zo blikt bijvoorbeeld dat mensen die op weekdagen minder dan gemiddeld slapen dit op weekenddagen inhalen (Knulst en Schoonderwoerd, 1983). Ook is een woordeel wan langere onderzoeksperiodes dat respondenten die met een lage frequentie deehemen aan activiteiten kunnen worden getraceerd. Wanneer iemand ển keer per week deelneemt aan een activiteit (bijvoorbeeld sport) is de kans dat hij of zij als sporter ontdekt wordt bij een dagboek van een dag $1 / 7$, bij een dagboek van ên week echter $7 / 7$. Wanneer een betrouwbare classificatie van individuen ten aanzien van een (voor sommigen of velen) laag frequent gedrag is gewenst, is een onderzoeksperiode van meer dagen noodzakelijk. Dagboeken van een week kunnen ten aanzien wan gedragingen die met een frequentie van minder dan 1 keer per week voorkomen op individueel nivenu geen goede resultaten leweren. Op geaggregeerd niveau zullen er geen verschillen in de resultaten zijn zolang de steekproef groot genoeg is. Wanneer er genoeg dagboeken van een dag, verspreid over week en weekenddagen en over de verschillende maanden van het jaar, worden verzameld kan er op dit niveau een synthetisch beeld wan de weekritmes, maar ook van de levenscyclus worden gevormd (Converse, 1968).

Een praktisch voordeel van een langere registratie periode is dat de kosten relatief lager zijn omdat het aantal bezoeken aan de respondent bij eendagsregistratie ewen groot is als bij een registratie van zeven dagen. Verder behoeft er, indien een gehele week is geregistreerd (en alle dagen dus evenredig zijn vertegenwoordigd in de analyses op geaggregeerd niveau niet te worden gewogen mar dagen.

\section{Toegevoegde informatie}

Behallve de timing, volgorde en duur van primaire activiteiten wordt vaak ook nog toegevoegde informatie geregistreerd. Deze registratie onnat bijvoorbeeld de plaats van handeling, het gezelschap of eventuele secundaire activiteiten (mogelijk ook drinkgedrag). Ook meer sociaal-psychologische factoren zoals de wijze warop het handelen beleefd wordt (prettig of onprettig) of de (sociale) betekenis die individuen aan hun handelen geven (Elchardus en van Rossem, 1985) kunnen op deze wijze worden geregistreerd.

De hoeveelheid extra informatie die wordt gevraagd, wordt alleen beperkt door de belasting die men de respondent wil of kan opleggen en de onderzoeksvraag. Het is wel waarschijnlijk dat naarmate er meer informatie wordt gevraagd de accuratesse waarmee de dagboeken worden ingevuld zal afnemen.

\subsection{De registratie van drinkgedrag}

In paragraaf 2.1 is geconstateerd dat het dagboek een geschikt instrument is om het dagelijks leven in zijn geheel van situaties te bestuderen. In tijdbestedingsonderzoek wordt drinken niet als een aparte activiteit beschouwd (Simpura, 1985). Noch in de uitgebreide activuteitenlijst van Knulst en Schoonderwoerd (1983), noch in de categorieën die Szalai (1971) of anderen (zie: Juster, 1985) hanteren komt (alcohol-)drinkgedrag als activiteit voor. Omgekeerd geldt dat in studies naar drinkgedrag geen systematische gegevens over de tijdbesteding worden verzameld. In deze paragraaf wordt onderzocht of het dagboek een geschikt instrument kan zijn om het drinkgedrag in het dagelijks leven te registreren.

Er zijn gegronde redenen om te twijfelen aan de betrouwbaarheid en validiteit van zelf- 
rapportage van drankgebruik in surwey-onderzoek. Met name de aanzienlijke versehillen tussen geschatte per capita consumptie op basis van zelf-rapportage ciffers en die op basis van officiële verkoopcijfers liggen aan twijfels over de valíditeit ten grondslag. De op basis van officiële verkoopciffers geschatte per capita consumptie wordt woor Nederland redelijk valide geacht (Lemmens, 1987). Oorzaken van de discrepantie tussen de officièle cijfers en schattingen van de per capita consumptie op basis van survey-gegevens moeten worden gezocht in de representativiteit van de steekproef en/of onderzoeksperiode, de gebruikte onderzoeksinstrumenten en de meestal niet opzettelijke onder- of overrapportage van respondenten. Hier zal met name worden ingegaan op de latatste twee aspecten.

Consumptieschattingen op basis van instrumenten die de typische of gemiddelde consumptie trachten vast te stellen blijken vaak aanzienlijk te laag te zijn (Lemmens, 1987; Simpura, 1987; Redman et al., 1987). Een voorbeeld van een dergelijk instrument is de zogenaamde usual quantity-frequency maat. Op basis van antwoorden op de vragen "Hoe vaak drinkt $U$ gewoonlijk?' en 'Hoeveel drinkt U gewoonlijk per keer?' wordt de totale consumptie berekend. Voor de Nederlandse situatie rapporteert Lemmens (1987) een onderschatting van de totale consumptie op basis van de usual quantity-frequency methode van maar liefst $56 \%$. Dat betekent dat minder dan de helft wan alle drankgebruik wordt gerapporteerd. Een deel van de onderschatting wordt veroorzaakt doordat respondenten een schatting van doorsnee of gemiddeld gedrag moeten geven. De algemene neiging in dergelijke situaties is om de frequentie van het gedrag te onderschatten (Redman et al., 1987). Dit doet zich met name voor bij een onregelmatig gedragspatroon (Sobell et all., 1988).

Net als voor de meting van de tijdbesteding geldt in het algemeen voor de meting van drankgebruik dat de meest accurate gegevens verkregen worden uit methoden die het daadwerkelijke gedrag registreren en geen samenvattende beschrijving van respondenten verlangen. Dergelijke methoden zijn bijvoorbeeld de 'weekly recall', de 'time-line' methode, de "last occasions" methode en alcoholdagboeken.

Geen van deze methoden is toegesneden op de studie van het drinkgedrag in het dagelijks leven. De kenmerken van de verschillende methoden maken het echter wel mogelijk om een indruk te krijgen van de bruikbaarheid van het tijdbestedingsdagboek. Daarom zullen ze hier achtereenvolgens worden beschreven.

\subsubsection{De weekly recall methode}

Bij de weekly recall methode (Room, 1985), ook wel het retrospectieve dagboek genoemd (Redman et al., 1987), wordt respondenten gevraagd om per dag van de afgelopen week aan te geven hoeveel ze hebben gedronken. De vraag kan worden gespecificeerd naar dranksoort en omstandigheid waarin het drinkgedrag heeft plaatsgevonden. Deze laatste specificatie blijft noodgedwongen grof. Er wordt een onderscheid gemaakt naar drankgebruik binnenshuis en buitenshuis. Philipsen et al. (1983) constateren dat er door deze methode voor de meest recente dagen meer drankgebruik wordt geregistreerd dan voor de dagen die verder in het verleden liggen. De onderschatting van totale consumptie (in 1981) op basis van de laatste twee dagen (gewogen naar dagsoort) is beduidend lager (44\%) dan die op basis van de afgelopen zeven dagen $(56 \%)$. Dit wordt verklaard als een geheugeneffect. Mensen vergeten meer van hun drankgebruik van de vorige week dan van dat van gister. Lemmens (1987) rapporteert dat door middel van de weekly recall methode ongeveer $60 \%$ van alle drankgebruik wordt gedekt. 
Op basis wan gegevens, verkregen door de weekly recall methode, kunnen variaties in drinkgedrag over de dagen wan de week worden onderzocht. Vergeleken met de usual quantity-frequency methode worden door de weekly recall methode meer mensen als zware drinkers geclassificeerd. De gemiddelde consumptie geregistreerd door de weekly recall methode is hoger dan die volgens de usual quantity-frequency methode. Redman et al. (1987) vinden gemiddelde consumpties wan respectievelijk 10.51 glazen (weekly recall) en 6.87 glazen (usual quantity-frequency) per week. Daar staat tegenover dat het aantal mensen dat geen drinkgedrag rapporteert bij gebruik van de weekly recall methode ook hoger is dan bij de usual quantity-frequency methode. Met name het classificeren van drinkers met een lage frequentie (minder dan een keer per week) is met de weekly recall methode onmogelijk.

\subsubsection{De time-line methode}

De time-line methode (Sobell et al., 1988) vraagt respondenten om hun drinkgedrag irn de afgelopen maand of zelfs het afgelopen kwartaal per dag te registreren. Vergeleken bij de usual quantity-frequency methode acht Sobell de time-line methode veruit superieur, zowel wat betreft de consistentie van antwoorden op verschillende tijdstippen als wat de indeling van respondenten op een consumptie-schaal aangaat. De time-line methode maakt lhet mogelijke om individuele patronen in drinkgedrag op te sporen. Sobell et al. (1988) stellen dat de time-line methode betrouwbare resultaten geeft. Ze baseren deze stelling op resultaten van een onderzoek waarin respondenten hun drinkgedrag per dag voor de afgelopen 90 dagen registreren op twee verschillende tijdstippen (6 weken tussentijd). Met betrekking tot de gemiddelde consumptie en frequentie per maand bleek sprake te zijn van een hoge test-hertest betrouwbararheid. Voor de verschillende maten vinden zij correlaties tussen de scores in verschillende periodes van tenminste .70 maar vaak van .80 of zelfs .95 . Respondenten worden bij het invullen van de kalender bijgestaan door interviewers. Deze wijzen hen op feestdagen en geven ook andere tips om het geheugen te stimuleren (ben je op bezoek geweest?, zijn er dagen waarop je altijd drinkt?). Er kan getwijfeld worden aan een dergelijke procedure. Mogelijk worden respondenten gestuurd om te registreren hoe vaak situaties voorkomen waarin ze normaal gesproken drank gebruiken. De motivatie woor de tips en het gebruik van een kalender is dat het scheppen van kaders het geheugen kan ondersteunen. Gegevens over de situaties waarin is gedronken worden niet geregistreerd. Sobell et al. (1988) achten het alcoholdagboek een geschiktere methode maar tekent daar bij aan dat deze laatste methode gevoeliger is voor non-respons en dat het bijhouden van een dagboek het drinkgedrag kan beinvloeden.

\subsubsection{De last-occasion methode}

De last occasion methode (Simpura, 1987) is voornamelijk gericht op de situaties waarin het drinkgedrag plaatsvindt. Per respondent wordt een onderzoeksperiode vastgesteld (minimal de afgelopen week, maximaal het afgelopen jaar). De duur van deze periode wordt gebaseerd op de drinkfrequentie zoals geschat door de respondent en zo gekozen dat er per respondent gemiddeld vier gelegenheden in vallen waarin zich drankgebruik heeft voorgedaan. Alle gelegenheden waarbij is gedronken worden vervolgens uitputtend beschreven. De methode levert een zeer gedetailleerd beeld van de situaties waarin wordt gedronken en de consumptie in die situaties. Ook de drinkgelegenheden van mensen die 
slechts zeer sporadisch drinken worden beschreven.

Ondat alleen situaties waarin is gedronken worden beschreven kan ook op grond wan de gegevens verkregen door deze methode geen onderscheid worden gemaakt tussen situaties waarin het gebruikelijk is om te drinken en situaties waarin drankgebruik nier of slechts sporadisch voorkomt. Er kan niet worden nagegaan hoe vaak zich gelijksoortige omstandigheden voordoen waarin niet wordt gedronken.

De last occasion methode is ontwikkeld in Scandinavië. De onderschatting van de totale consumptie is hier traditioneel erg groot. Simpura (1985) geeft cijfers die aanduiden dat de onderschatting rond de $70 \%$ ligt. Gezien de eveneens traditioneel hoge respons in de Scandinavische landen moet dit voornamelijk toegeschreven worden aan het al dan niet opzettelijk vergeten van drinkgedrag. Naast bewuste onderrapportage noemt hij als mogelijke bronnen van onderschatting het vergeten van drinkgelegenheden dan wel van de gedronken hoeveelheden tijdens die gelegenheden.

\subsubsection{Alcoholdagboeken}

Prospectieve alcoholdagboeken blijken het meeste drankgebruik boven tafel te halen (Poïkolä̈nen en Kärkkäinen, 1983, Lemmens et al., 1988). Bij deze methode wordt door respondenten een boekje bijgehouden waarin ze, liefst meteen, registreren wat ze hebben gedronken. Het vergeten van drinkgedrag (gelegenheden of hoeveelheden) als bron van vertekening wordt daardoor uitgeschakeld. Poïkolaïnen en Kärkkaïnen (1983) schatten de validiteit van deze methode ter vaststelling van de gemiddelde dagelijkse consumptie op $90 \%$ of hoger. Ze gaan ervan uit dat het door deze dagboeken gerapporteerde drinkgedrag overeenkomt met het werkelijke gebruik van alcoholhoudende dranken. In een onderzoek bij gemotiveerde vrijwilligers constateren zij dat een usual quantity-frequency maat slechts $60 \%$ van het totale alcoholgebruik zoals gemeten met het dagboek registreert. Ze concluderen hieruit dat de onderschatting (door de usual quantity-frequency methode) met name door de methode veroorzaakt wordt en dus niet het gevolg is van bewuste onderrapportage.

Door het bijhouden van een alcoholdagboek worden respondenten zeer nadrukkelijk geconfronteerd met hun drinkgedrag (Poïkolänen en Karkkaïnen, 1983; Sobell et al., 1988). Dit kan een mogelijke foutenbron zijn wanneer men hierdoor tijdens de registratie-periode zijn drinkgedrag veranderd. Lemmens et al. (1988) vinden evenwel geen verschil in de gemiddelde consumptie tussen twee opeenvolgende weken waarin een alcoholdagboek is bijgehouden. De schatting van het totale drankgebruik door middel van deze dagboeken is $22 \%$ hoger dan die door middel van het retrospectieve dagboek (weekly recall).

Alcoholdagboeken zijn de meest accurate methode om drinkgedrag te registreren. Ze leveren de hoogste schatting van de totale consumptie (Lemmens et al., 1988) en biedlen de gelegenteid om zeer gedetailleerde temporele variaties in drinkgedrag (per dag, per uur) te onderzoeken. De rangorde correlatie tussen resultaten van dagboeken en andere methoden om drankgebruik te meten is hoog (Lemmens et al., 1988). Dit duidt erop dat de classificaties van drinkers niet ernstig wordt verstoord door meting van het gedrag in een korte periode. Een mogelijk voordeel van deze methode is dat door middel van toegewoegde informatie ook gegevens over de omstandigheden waarin drinkgedrag plaatsvindt kunnen worden verzameld. 


\subsubsection{Het tijdbestedingsdagboek als instrument}

Een tijdbestedingsdagboek lijkt een zeer geschikte methode ter bestudering van drinkgedrag in het dagelijks leven. Het combineert de voordelen van de dagboekmethode, de time-line methode en de last occasions methode. De tijd tussen drinkgedrag en het invullen van de dagboeken is kort wadrdoor de kans op het vergeten van drankgebruik geminimaliseerd wordt. Een verdere steun voor het geheugen is dat niet alleen het drinken maar ook de activiteiten en het temporele kader waarin dit plaatsvindt (kloktijd) worden aangegeven. De registratie van tijdbesteding is niet alleen een steun bij de registratie van drinkgedrag. Deze maakt het ook mogelijk om een beschrijving te geven van de situaties waarin het drinkgedrag plaatsvindt en om te onderzoeken in hoeverre gelijksoortige situaties voorkomen waarin niet wordt gedronken. Temporele patronen in drinkgedrag en de relaties tussen de structuur van het dagelijks leven en drinkgedrag kunnen worden onderzocht.

De wijze waarop drinkgedrag in een tijdbestedingsdagboek moet worden geregistreerd vormt een technisch probleem. In hoofdstuk 1 is geconstateerd dat drinken moet worden beschouwd als een handeling die haar betekenis ontleent aan de activiteit waarbinnen ze platsvindt. Drinkgedrag is voor veel mensen 'slechts' een bijkomstigheid (Simpura, 1985; Weiss, 1985). Daarom kan drinken niet als activiteit in het dagboek worden opgenomen. Het opnemen van drinken als secundaire activiteit is een beter alternatief. Om te garanderen dat drinkgedrag wordt geregistreerd zal expliciet moeten worden gevraagd wat er is gedronken. Anders bestaat de kans dat men het drinken als een irrelevante bijkomstigheid ziet en dus gewoon niet registreert. Door nadruk te leggen op alcoholgebruik worden effecten van sociale wenselijkheid echter vergroot. Een mogelijke oplossing hiervoor zou kunnen zijn om naast het alcoholgebruik ook ander consumptiegedrag te registreren. Invloeden van het bijhouden van een dagboek op het drinkgedrag kunnen worden beperkt of voorkomen door de periode tijdens welke het dagboek wordt bijgehouden te beperken.

Drinkgedrag is situatiegebonden. Wanneer zich uitzonderlijke, niet alledaagse omstandigheden voordoen tijdens de dagboekperiode kan dat het drinkgedrag van een individu beïnvloeden. Voorbeelden zijn feestjes of ziekte. Voordeel van een tijdbestedingsdagboek is dat naast het drankgebruik ook activiteiten worden geregistreerd. Hierdoor kan gecontroleerd worden voor de omstandigheden waarin het drinkgedrag voorkomt. Of bepaalde omstandigheden woor een individu uitzonderlijk zijn of niet kan niet worden vastgesteld. Een nadeel van alle methoden die concreet gedrag gedurende een korte periode registreren is de twijfelachtige representativiteit van de verkregen gegevens voor het 'doorsnee' gedrag van een individu. Elliot en Cosper (1982) vergelijken de frequentie van bezoek aan openbare drinkgelegenheden zoals blijkt uit (een-dags) dagboeken en zoals berekend op grond van een vraag naar gemiddelde bezoekfrequentie. De resultaten zijn van beide methoden zijn vergelijkbaar. In Halifax (Canada) bezoekt op een willekeurige dag van de week ongeveer $7 \%$ van de populatie een dergelijke gelegenheid. Daar staat tegenover dat het grootste deel wan alle café-bezoekers regelmatige bezoekers zijn. Op grond wan (eendags) dagboeken kan niet bepaald worden of iemand die een café bezoekt dit elke dag doet of dat het bezoek slechts incidenteel is. Individuele patronen in gedrag kunnen door dagboeken (of andere 'actual' methoden) niet worden vastgelegd. Op geaggregeerd niveau zal dit de representativiteit van gegevens echter niet of nauwelijks beïnvloeden.

In deze studie zal gebruik worden gemaakt van data verkregen door middel van een tijdbestedingsdagboek. 
Het tijdbestedingsdagboek is voor zover bekend niet eerder gebruikt on drinkgedrag te registreren. Op grond van bovenstaande mag evenwel worden geconcludeerd dat het tijdbestedingsdagboek een goede methode kan zijn om het drinkgedrag in het dagelijks leven te onderzoeken. Het is een valide en betrouwbare methode om tijdbesteding en drinkgedrag te registreren. Het tijdbestedingsdagboek biedt de mogelijkheid om de omstandiglneden waarin drinkgedrag wordt gerealiseerd te onderzoeken. De tijden waarop en activiteiten waarbij wordt gedronken kunnen zeer specifiek worden omschreven. Daarnaast is het op basis van dagboekgegevens mogelijk om vast te stellen in hoeverre situaties waarin drinkgedrag plaatsvindt in het dagelijks leven voorkomen zonder dat erin wordt gedronken. Niet alleen de kenmerken van sociale drinkgewoonten kunnen worden omschreven malar ook de mate waarin drinken als 'normaal' wordt beschouwd binnen situaties kan worden vastgesteld.

De praktische problemen, hoge kosten en complexe data, zijn nog de grootste obstakels om zulke methoden toe te passen.

\subsection{Het materiaal}

De gegevens, die hier worden gebruikt, zijn verkregen uit een grote survey die in 1985 is uitgevoerd. Verschillende doelstellingen lagen aan deze data-verzameling ten grondslag. Een van de onderzoeken warin van de data gebruik is gemaakt, betrof de validiteit van het Ledermann-model (Lemmens, 1987). Doel van die studie was om te onderzoeken welk statistisch model het beste de verdeling van drinkers over opeenvolgende consumptiecategorieën, alsmede de spreiding van drinkers rond de gemiddelde consumptie bij verschillende consumptieniveau's per capita beschrijft. Daarbij werd tevens onderzocht in welke mate de onderschatting van de alcoholconsumptie in empirisch onderzoek de toepasbaarheid van het Ledermann-model beinvloedt. De beschrijving van het gebruikte materiaal en de gehanteerde procedures die hier volgt is volledig gebaseerd op het rapport 'Het Ledermann-model nader bezien' (Lemmens, 1987). Voor een uitgebreide beschrijving van procedures en resultaten van het onderschattingonderzoek zij verwezen naar dit rapport. Hier volgt slechts een summiere beschrijving.

\subsubsection{De steekproef}

De 1985-survey bestaat uit een representatieve steekproef uit de Nederlandse bevolking in de leeftijdscategorie van 16 tot 70 jaar. De steekproeftrekking is uitgevoerd volgens een gestratificeerd, stapsgewijze procedure. Stap 1 was de selectie van gemeenten. Stratificatic vond plaats aan de hand van regio en urbanisatiegraad, De selectie van gemeenten was aselect met uitzondering van de grote steden. Stap 2 was de selectie van respondenten. Deze werden a-select uit de bevolkingsregisters van de geselecteerde gemeenten getrokken.

De totale steekproef werd opgesplitst in 5 sub-steekproeven van personen, die in verschillende periodes zouden worden benaderd. In alle maanden van het jaar behalve januari en februari hebben interviews plaatsgevonden. De survey bestond uit 3 vragenlijsten te weten een mondeling interview van de respondent (A), een interview met de partner van de respondent (B) en een dagboekvragenlijst (C). Een interview werd als geslaagd beschouwd indien minimaal complete vragenlijsten $A$ en $C$ werden verkregen. 
In figuur 2.1 is per maand weergegeven hoeveel personen een dagboekvagenlijst hebben ingevuld. De latate interviewgolf is uitgevoerd tijdens de laatste week van november en de eerste week wan december, dagboeken hierbij behorend zijn rond de jaarwisseling ingevuld. Deze groep interviews wordt angeduld met 'de Kerstgolf.

In totalal werden er 1732 personen benaderd, 1274 hiervan voltooiden een mondeling interview (A); 1240 dalarwan vulden daarnaast een dagboekwagenlijst (C) volledig in. De non-respons bedroeg dus $28,4 \%$. Vergeleken met de non-respons van het tijdbestedingsonderzoek uitgevoerd door het Sociaal en Cultureel Planbureau in 1980 (47\%)

\section{Figuur 2.1}

Het aantal ingevulde dagboeken per maand $(n=1240)$

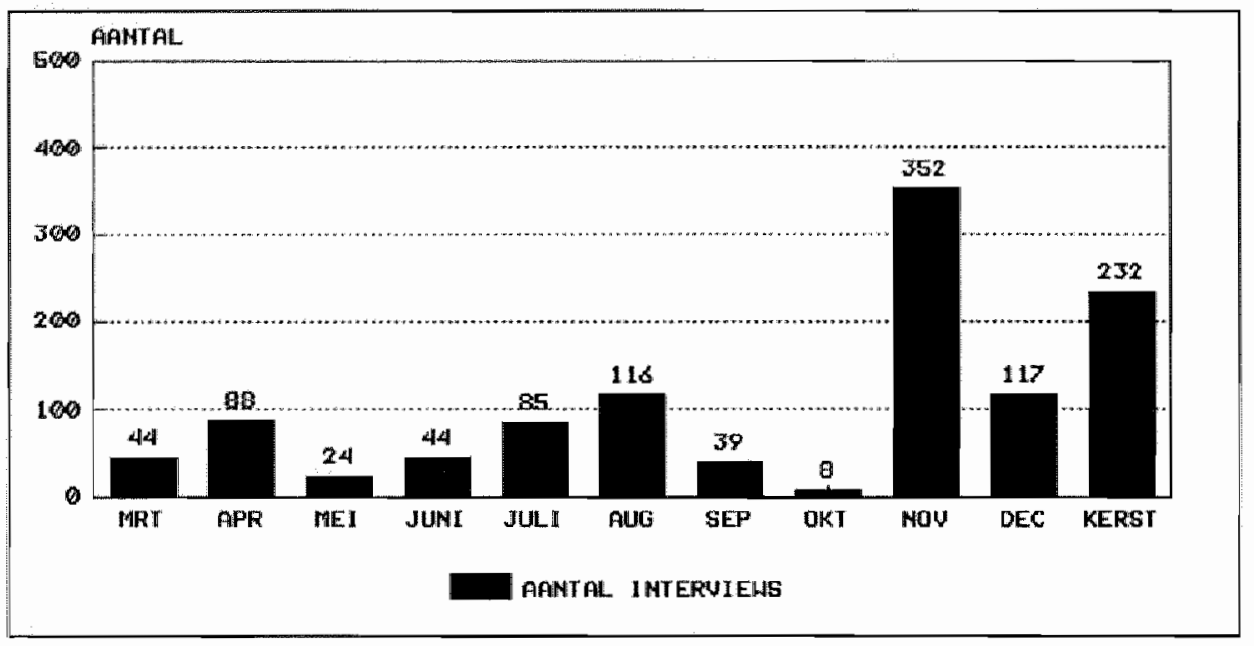

Bron: Lemmens (1987)

(Knulst, 1983) is dit zeer acceptabel. De non-respons was niet in alle sub-populaties gelijk. In regio Oost was ze lager dan gemiddeld $(21 \%)$ in regio West hoger $(32 \%)$. In de leeftijdscategorie van $26-35$ jaar was ze lager (24\%), in de groep tussen 46 en 55 jaar hoger dan gemiddeld (32\%). Voor mannen en vrouwen was de non-respons gelijk.

De data die in dit proefschrift worden gebruikt zijn voornamelijk afkomstig uit de dagboekvragenlijst. Deze zal hierna iets uitgebreider worden beschreven.

\subsubsection{De dagboekuragenlijst}

De dagboekvragenlijst bestond uit een boekje waarin gedurende 7 opeenvolgende dagen moest worden bijgehouden welke activiteiten men had ondernomen en wat men daar eventueel bij had gedronken. Deze gegevens moesten per kwartier worden geregistreerd. Zowel de activiteiten als de dranksoort moesten uit vooraf vastgestelde categorieën worden 
gekozen. Een voorbeeld van een bladzijde uit het dagboek is weergegeven in Bijlage 2.1, de gebruikte categorieën van activiteiten en de toelichting daarop zijn weergegeven in Bijlage 2.2. Respondenten werden geinstrueerd het dagboek een of twee maal per dag in te vullen.

De verschillende soorten dranken die men kon registreren waren 'koffie, thee' . 'zuiveldranken', 'water, frisdranken en vruchtesappen', 'bier', 'wijn', 'sherry, port, martini' en 'sterke drank puur, gemixed'. Naast deze gegevens per kwartier werd per dagdeel (6 uur) geregistreerd of er medicijnen (slaapmiddelen, kalmerende middelen of overige) gebruikt waren en of en thoeveel er gerookt was (sigaret, sigaar, pijp).

In deze studie is alleen gebruik gemaakt van de gegevens met betrekking tot activiteiten en de consumptie van alcoholische dranken. Daar het drinkgedrag in het gewone dagelijks leven centraal staat in deze studie, zijn de gegevens betreffende de Kerstgolf niet gebruikt. Dat betekent dat er in totaal gegevens van 920 respondenten beschikbaar waren voor analyse. Voor 4 respondenten kon geen koppeling worden gelegd tussen wragenlijst en dagboek. Uiteindelijk zijn de analyses uitgevoerd op de gegewens van de resterende 916 respondenten. Kenmerken van de respondenten zoals status- en positierollen zijn gemeten met de worgestructureerd vragenlijst (A).

\subsection{Analyse, eenheden en maten}

Het in deze studie gebruikte materiaal is in grote lijnen vergelijkbatar met de dagboekgegevens die door Knulst en Schoonderwoerd (1983) in de studie 'Waar blifft de tijd?' zijn gebruikt. De gegevens zijn voor een gehele week per kwartier geregistreerd met een gesloten activiteitenregistratie. Knulst hanteert meer activiteitencategorieën maar registreert geen drinkgedrag. Knulst en Schoonderwoerd stellen de data woor als the verkregen uit een schriftelijke enquête waarin de respondenten 672 (kwartieren per week) keer een antwoord hebben gegeven op de vraag "Wat deed $U$ in het afgelopen kwartier?". Behalve door de omvang van het materiaal wijkt de analyse van tijdbestedingsdata af van die van gebruikelijke enquetes doordat het verschillende dimensies in katart brengt. Zij omschrijven drie dimensies: de respondenten, de deelname aan activiteiten en de tijd. In deze studie vormt het drinkgedrag een vierde dimensie.

In de beschrijving van afzonderlijke activiteiten kunnen, los van drankgebruik, drie fundamentele maten worden onderscheiden. Deze maten zijn:

-deelname (in personen $\mathrm{N}$ )

-tijdbesteding of duur (in kwartieren 'T) en

-frequentie (in gelegenheden F).

De tijcbesteding is per kwartier geregistreerd. Wanneer lemand meer dan een kwartier besteed aan een activiteit wordt de totale periode (opeenwolgende kwartieren) een gelegenheid genoemd. Gelegenheden zijn ononderbroken reeksen van kwartieren waarin de primaire activiteit dezelfde is. Frequentie wordt uitgedrukt in het aantal gelegenheden per tijdsperiode.

Voor drinkgedrag kunnen, analoog hieraan, ook drie fundamentele maten worden onderscheiden. Dit zijn:

-drinkers (in personen DN).

-consumptie (in drinkkwartieren DT) en

-drinkfrequentie (in drinkgelegenheden DF). 
Drinkers zijn degenen dis in een bepaalde tijdsperiode alcohol hebben gebruikt.

Net als activiteiten is drankgebruik per kwartier geregistreend. Een kwartier tijdens welk drinkgedrag is gerapporteend wordt een drinkkwartier genoemd. De consumptie wordt uitgedrukt in hei aantal drinkkwartieren.

Een gelegenheid is een gedragseenheid bestande uit een of meer opeenvolgende kwartieren gekenmerkt door dezelfde activiteit. Een gelegenheid tijdens welke drinkgedrag is gerapporteerd wordt een drinkgelegenheid genoemd. Het aantal drinkgelegenheden in een bepaalde periode is een maat woor drinkfrequentie.

Zoals gebruikelijk in socialal-wetenschappelijk onderzoek is ook in tijdbestedlingsonderzoek het individu of een cattegorie van individuen met vergelijkbare kenmerken (de mannen, de vrouwen) meestal de analyse-eenheid (Harvey et al., 1984). Per tijdsperiode (dag, week, jaar) kan het aantal drinkers (DN) en de totale consumptie (DT) worden vastgesteld, Bij] specificatie van de activiteit (i) kan ook het aantal deelnemers (Ni) worden vastgesteld en het antal drinkende deelnemers (DNi). Bij tijdsintervallen die langer duren dan een kwartier kunnen naast deelname ook de duur (Ti) en de frequentie (Fi) per activiteit worden bepaald.

De verschillende maten kunnen worden gecombineerd. De duur per deelnemer kan worden berekend als $\mathrm{Ti} / \mathrm{Ni}$, de duur per gelegenheid als $\mathrm{Ti} / \mathrm{Fi}$, de consumptie per drinker als DT/DN, de consumptie per deelnemer als DT/N. Al deze maten kunnen per tijdsinterval, bijvoorbeeld per dang of dagdeel worden berekend. Ook dagen of gelegenheden kunnen echter als analyse-eenheid worden gebruikt. Ter illustratie van de vele mogelijke variaties zal hieronder het drinkgedrag in de dagboekweek worden beschreven.

\subsubsection{Drinkgedrag tijdens de dagboekweek}

Van de 916 'deelnemers' (N) aan de dagboekweek drinken er 670 (DN). Het percentage drinkers is (DN/N"100 =) $73 \%$. Het aantal dagen (D) per drinker is vast ( 7 dagen per week * 670 drinkers $=4690$ dagen). De som over alle respondenten van het aantal dagen waarop is gedronken (DD) is 2844. Dit is (DD/D*100 $) 61 \%$ van alle dagen en (DD/DN) 4,2 dagen per drinker.

\section{Tabel 2.1}

De omvang van het drankgebruik in de onderzoekspopulatie tjidens de dagboekweek.

\begin{tabular}{lccc} 
Eenheid & Mannen & Vrouwen & Iotaal \\
\hline Drinkkwartier (DT) & 7113 & 2519 & 9632 \\
Drinkgelegenheid (F) & 2798 & 1456 & 4254 \\
Drinkdagen (DT) & 1817 & 1027 & 2844 \\
Drinkers (DN) & 395 & 275 & 670 \\
Deelnemers (N) & 493 & 423 & 916 \\
\hline
\end{tabular}


Indien iemand op een dag bij meer dan een activiteit drinkt realiseert die persoon verschillende drinkgelegenheden.De som over alle respondenten van aantal gerealiseerde drinkgelegenheden tijdens de dagboekweek (DF) is in het hiter gebruikte materiaal 4254 dat zijn dus gemiddeld (DF/DD) 1.5 gelegenheden per dag waarop gedronken is (dag als analyse-eenheid) of (DF/DN) 6,3 drinkgelegenheden per drinker (drinkers als analyseeenheid). De som over alle respondenten van de kwartieren waarbij drinkgedrag is gerapporteerd (DT) bedraagt 9632 drinkkwartieren (week als analyse-eenheid). Dat is gemiddeld (DT/DF) 2.26 drinkkwartier per drinkgelegenheid of (DT/DN) 14.4 drinkkwartieren per drinker per week.

Van alle beschikbare tijd in kwartieren ( 670 drinkers * 7 dagen * 168 kwartier $=787.920$ ) gaat $1,2 \%$ vergezeld van drankgebruik (kwartier als analyse-eenheid).

In tabel 2.1 staan deze gegevens nog eens op een rijtje en worden ze voor mannen en wrouwen afzonderlijk getoond.

Behalve per categorie (zoals hierboven geslacht) kunnen gegevens ook per activiteit worden gepresenteerd. In tabel 2.2 wordt het aantal drinkgelegenheden (DF) en het aantal drinkers (DN) per activiteit weergegeven. De tabel toont bijwoorbeeld aan dat het drinken tijdens het televisiekijken bij mannen een kwart en bij wrouwen $1 / 5$ van alle drinkgelegenheden vertegenwoordigd. Wanneer het individu als analyse-eenheid wordt gebruikt kan worden vastgesteld dat van de drinkende mannen $63 \%$ en van de vrouwen $47 \%$ tijdens de dagboekweek bij het televisiekijken drinkt. Alle tot nu toe behandelde data betreffen maten voor éen tijdsinterval (week), verschillende tijdsintervallen (bijwoorbeeld dagen) kunnen natuurlijk ook met elkaar worden vergeleken. In tabel 2.3 is het aantal drinkgelegenheden en het aantal drinkers per dag weergegeven.

Natuurlijk kunnen de tijdsintervallen nog specifieker gedefinieerd worden, in hoofdstuk 3 worden bijvoorbeeld het aantal drinkers per uur en per dagdeel (ochtend, middag, avond) onderzocht (zie ook bijlagen bij hoofdstuk 3).

De voorbeelden die hierboven werden gegeven hebben betrekking op drinkgedrag. De maten echter zouden evengoed voor activiteiten kunnen worden gebruikt. Alle gepresenteerde maten zijn min of meer rechtstreekse tellingen. In tijdbestedingsonderzoek kunnen daarnatast ook samengestelde maten worden gebruikt. Knulst en Schoonderwoerd (1983) geven bijvoorbeeld een maat voor de versnippering van de wrije tijd. Ook maten voor het aantal verschillende activiteiten per dag (van Gelooven et al., 1987) en dergelijke kunnen zinvolle informatie geven. Harvey (1984) geeft een maat waarmee de gelijksoortigheid van dagen wat betreft de totale duur besteed aan activiteiten in een populatie kan worden uitgedrukt. Deze kan worden vertaald in een maat woor de individuele routine in gedrag (van Gelooven et al., 1988). Ook de routine in de timing van activiteiten kan worden berekend (van Gelooven et al., 1988). 
Tabel 2.2

Het aantal drinkgelegenheden (DF) en drinkers (DN) per activitent per week voor mannen en wrouwen atzonderijk.

\begin{tabular}{|c|c|c|c|c|c|}
\hline \multirow[b]{2}{*}{ Kode } & \multirow[b]{2}{*}{ Activiteit } & \multicolumn{2}{|c|}{ Mannen } & \multicolumn{2}{|c|}{ Vrouwen } \\
\hline & & DF & DN & DF & DN \\
\hline 8 & Kerk & 2 & 2 & 1 & 1 \\
\hline 10 & Team sport & 8 & 8 & 1 & 1 \\
\hline 13 & Vrijw, werk & 10 & 7 & 2 & 2 \\
\hline 11 & Indiv sport & 11 & 11 & 6 & 5 \\
\hline 7 & School & 15 & 12 & 0 & 0 \\
\hline 6 & Verz. kinderen & 18 & 13 & 9 & 7 \\
\hline 3 & Pers. behoeften & 18 & 17 & 19 & 17 \\
\hline 15 & Societeit & 24 & 14 & 6 & 5 \\
\hline 9 & Organisatie & 26 & 24 & 4 & 4 \\
\hline 1 & Slatap/bed & 26 & 20 & 8 & 7 \\
\hline 12 & Participatie & 31 & 27 & 9 & 8 \\
\hline 22 & Rekreatie buiten & 38 & 29 & 12 & 12 \\
\hline 20 & Uit anders & 47 & 40 & 31 & 30 \\
\hline 5 & Huishouden & 49 & 36 & 61 & 40 \\
\hline 21 & Karweitjes & 51 & 33 & 8 & 7 \\
\hline 14 & Sportkantine & 56 & 42 & 5 & 5 \\
\hline 27 & Overigen & 68 & 46 & 35 & 27 \\
\hline 4 & Werk & 89 & 57 & 8 & 7 \\
\hline 23 & Hobbies & 92 & 62 & 81 & 54 \\
\hline 26 & Lezen & 134 & 82 & 73 & 53 \\
\hline 19 & kontakt huisgen. & 148 & 87 & 57 & 38 \\
\hline 16 & Café/restaurant & 191 & 99 & 88 & 55 \\
\hline 25 & Ontspannen & 195 & 102 & 127 & 69 \\
\hline 17 & Visite familie & 253 & 176 & 143 & 105 \\
\hline 2 & Eten & 258 & 138 & 198 & 102 \\
\hline 18 & Visite vrienden & 269 & 180 & 180 & 111 \\
\hline 24 & Massa-media & 671 & 250 & 284 & 129 \\
\hline
\end{tabular}

' voor uitgebreidere omschrijving van activiteiten zie bijlage 2.2 


\section{Tabel 2.3}

Het aantal drinkgelegenheden (DF) en het aantal drinkers (DN) per dag wan de week voor mannen, vrouwen en in totaal.

\begin{tabular}{lllllll}
\hline & \multicolumn{2}{c}{ Mannen } & \multicolumn{2}{c}{ Vrouwen } & \multicolumn{2}{c}{ Totaal } \\
Dag & DF & DN & DF & DN & DF & DN \\
\hline Zondag & 487 & 294 & 264 & 174 & 751 & 468 \\
Maandag & 329 & 220 & 140 & 102 & 469 & 322 \\
Dinsdag & 339 & 229 & 166 & 123 & 505 & 352 \\
Woensdag & 349 & 241 & 177 & 128 & 526 & 369 \\
Donderdag & 366 & 241 & 183 & 133 & 549 & 374 \\
Vrijdag & 435 & 279 & 232 & 168 & 667 & 447 \\
Zaterdag & 493 & 313 & 294 & 199 & 787 & 512 \\
\hline
\end{tabular}

Het aantal mogelijkheden waarop tijdbestedingsmateriaal kan worden benaderd is vrijwel onbeperkt. Het wordt alleen begrensd door technische (bijvoorbeeld computercapaciteit) en creatieve factoren.

Vanwege de grote complexiteit van dagboekmateriaal is het steeds van belang om duidelijk te stellen wat de eenheid van analyse is en welke meeteenheden worden gebruikt. Dit is des te meer zo omdat een analyse-eenheid in de ene analyse meeteenheid in een andere analyse kan zijn. Bij onderzoek naar de spreiding van totaal drankgebruik over verschillende activiteiten kan het drinkkwartier als analyse-eenheid worden gebruikt. Wanneer daarentegen de verschillen in drinkgedrag tussen bijvoorbeeld jongeren en ouderen zouden worden onderzocht, is het drinkkwartier een meeteenheid. 



\section{Hoofdstuk 3 \\ Sociale drinkgewoonten: drinksituaties in Nederland}

\subsection{Inleiding}

In dit hoofdstuk wordt het alcoholgebruik in Nederland beschreven aan de hand van de data verzameld met de dagboekmethode. Het eerste deel van dit hoofdstuk is gewijd aan de situaties waarin alcoholgebruik plaatswindt. In het tweede deel van dit hoofdstuk wordt nagegaan of er naar gelang consumpticniveau verschillen zijn in de verdeling wan de consumptie over de te onderscheiden drinksituaties en/ of de consumptie bimnen een of meer van deze drinksituaties.

\subsubsection{Drinkgelegenheden en drinksituaties}

In hoofdstuk 1 zijn twee manieren warop het dagelijks leven kan worden beschouwd, beschreven. Vanuit de optiek van de waarnemer kan het dagelijks leven worden opgevat als een reeks wan activiteiten, eenheden wan gerealiseerd gedrag. Vanuit de sociale actor kan het dagelijks leven worden gezien als een reeks van contexten, situaties warin gedrag moet worclen gerealiseerd. In elke context bestaat, althans theoretisch, de mogelijkheid om alcohol te gebruiken. Wanneer een sociale actor daadwerkelijk drinkt binnen een context, realiseert hij een drinkgelegenheid. De totale consumptie van een individu tijdens een afgebakende periode (bijvoorbeeld de dagboekweek) kan worden opgevat als de som van het drankgebruik in alle door dat individu gerealiseerde drinkgelegenheden. De totale consumptie van een populatie kan op dezelfde wijze worden beschreven als de som van het drankgebruik in alle door de leden van die populatie gerealiseerde drinkgelegenheden.

Contexten die als eenzelfde lideaal-typische situatie worden opgevat en warin drinkgedrag acceptabel wordt geacht worden hier drinksituaties genoemd. Drinkgelegenheden zijn dus daadwerkelijk gerealiseerd gedrag. Drinksituaties zijn contexten warbinnen drinkgedrag acceptabel wordt geacht. 
Niet elke drinkgelegenheid word dus binnen een drinksituatie gerealiseerd en niet iedere keer dat een drinksituatie zich voordoet behoeft daarin ook daladwerkelijk te worden gedronken. In navolging van Gadourek (1963), Schippers (1981) en Knibbe (1984) wordt drinkgedrag hier gerekend tot de categorie der sociale gewoonten. De sociale drinkgewoonten in een populatie kunnen worden omschrewen aan de hand van de kenmerken van de drinksituaties in die populatie.

In thet hiernawolgende zal allereerst worden beschreven wat volgens de literatuur de sociale drinkgewoonten in Nederland zijn. Daarbij zal blijken dat de beschrijving van de sociale drinkgewoonten nogal globaal is. Op basis wan het dagboekmateriaal zal vervolgens een specifieke omschrijwing van de socialle drinkgewoonten in Nederland worden gegeven.

\subsubsection{De drinkgewoonten in Nederland}

De afgelopen decemia zijn er in Nederland verschillende onderzoeken gedaan naar het drinkgedrag van de algemene populatie. Met betrekking tot drinkgewoonten, beschouwd als de omstandigheden waaronder het drankgebruik plaatswindt, komen deze onderzoeken allen tot overeenkomstige algemene conclusies. In het hiernavolgende zullen deze conclusies worden gepresenteerd. Op grond daarvan zullen verwachtingen met betrekking tot kenmerken van drinksituaties worden omschmeven en zullen de onderzoekswragen worden geformuleerd.

Gadourek (1963) rapporteent in zijn boek "Riskante gewoonten" over het drinkgedrag van de Nederlandse bevolking in 1958 . Hij constateert dat er een wekelijks ritme in het drinkgedrag bestaat. Dit baseent hij op de antwoorden op vraag of men op bepaalde dagen meer drinkt dan op anderen. Hoewel $58 \%$ van de respondenten (totale $n=1297$ ) aangaf geen voorkeur voor bepaalde dagen te thebben kon bij de overige respondenten wel een duidelijke voorkeur worden geconstateerd. De 256 respondenten die een voorkeur uitspraken gaven aan dat ze op zaterdag en/of zondag meer dronken dan op andere dagen. Slechts 18 personen gaven een voorkeur aan een andere dag van de week. Expliciet gevraagd naar drankgebruik in verband met werk gaf $10 \%$ van de populatie aan wel eens te drinken in verband met werk of met mensen die verband hielden met het werk. Onder deze mensen bevonden zich relatief veel middenstanders. Opvallend is verder dat van degenen die veel dronken (meer dan 16 glazen per week) $45 \%$ aangaf weleens in verband met werk te drinken. Drinken bij het eten was in 1958 iets dat nauwelijks woorkwam.

Een indicatie voor de plaats war het drinkgedrag zich afspeelde in 1958 leidde Gadourek af uit de antwoorden op de (gesloten) vraag of men weleens een glaasje aanbood en zo ja waar. Van de manmen deed $60 \%$ en van de vrouwen $74,4 \%$ dat weleens thuis. Van de mannen deed $11,4 \%$ dat weleens in het café en $13,4 \%$ weleens thuis èn in het café. Van de mannen deed $14,3 \%$ het niet of gaf geen adequat antwoord, bij de vrouwen was dit $22,0 \%$. Het aanbieden van drank in een café werd door vrouwen nauwelijks of niet gerapporteerd $(1,0 \%$ in het café en $2,8 \%$ thuis en in het café). Gadourek concludeert hieruit dat een verrassende meerderheid van de bevolking thuis drinkt en anderen de drank gunt.

Sijlbing heeft in 1978 gerapporteerd over een landelijk onderzoek in 1976 dat een gedeeltelijke replicatie van het onderzoek van Gadourek was. Ook hij concludeert dat een groot deel van de populatie thuis drinkt. Hij baseert dit op de antwoorden op vraag waar men voor het laatst heeft gedronken. Thuis of bij anderen thuis antwoordde $64,5 \%$ van de populatie, $7,7 \%$ gaf aan dat dit in een café was en $1,0 \%$ vermeldde de werkplek. Deze antwoorden kwamen voort uit een gesloten vraag, warin bovenstaande platsen en 'anders' als antwoordcategorieën waren opgenomen. 
Schippers (1981) concludeerde uit data verzameld in 1975 dat de drinkgewoonten sinds 1958 niet of nauwelijks waren veranderd. In tegenstelling tot Gadourek en Sijlbing heeft Schippers de verdeling van het drankgebruik gebaseerd op het aantal glaasjes dat was gedronken en de plaats waar, tijd waarop en het gezelschap waarin dat gebeurde. Zijn analyse-eenheid was dus het gedronken glas alcohol en niet de drinkende persoon. Hij concludeert dat $47 \%$ wan alle glazen gedronken worden in gezelschap van een lid van het gezin en $37 \%$ in gezelschap van familieleden of vrienden. Een groot deel van de alcohol werd in hwiselijke kring geconsumeerd, $62 \%$ thuis en $17 \%$ bij anderen thuis. In het café werd $18 \%$ van het totale aantal glazen geconsumeerd en op het werk $3 \%$.

Met betrekking tot de tijden warop wordt gedronken concludeert Schippers dat $45 \%$ van alle drank in het weekend (van vrijdagavond tot zondagavond, 33\% van de totale tijd) wordt geconsumeerd en $3 / 4$ van alle drank 's avonds. In het weekend drinkt men 's middags en 's ochtends meer dan op doordeweekse dagen.

Het onderzoek van Schippers was niet landelijk en de steekproeftrekking was niet geheel toevallig. Van representativiteit voor de gehele bevolking kan dan ook geen sprake zijn (van Reek et al, 1984).

Een ander regionaal onderzoek uitgevoerd in 1980 (Knibbe, 1982) geeft ook de mogelijkheid plaats en dag van het alcoholgebruik te specificeren. In dit onderzoek is weer uitgegaan wan de respondent als analyse-eenheid. Van de mannen geeft $40,1 \%$ aan niet op weekdagen te drinken (afgelopen half jaar) en $16,9 \%$ niet in het weekend. Bij de vrouwen bedragen deze percentages respectievelijk $62,3 \%$ en $36,6 \%$. Met betrekking tot de plaats van het drankgebruik geeft $90 \%$ van de mannen en $80 \%$ van de vrouwen aan weleens thuis gedronken te hebben in het afgelopen half jaar. Respectievelijk $75 \%$ (mannen) en $61 \%$ (vrouwen) noemde het café, $87 \%$ en $84 \%$ bij familie, $22 \%$ en $12 \%$ in een clubhuis, $23 \%$ en $9 \%$ in een kantine en $16 \%$ en $10 \%$ op het werk of op school. Ook deze resultaten komen voort uit antwoorden op een gesloten vraag.

Al de hierboven genoemde onderzoeken komen tot gelijksoortige conclusies over de aard der drinkgewoonten in Nederland. Dit is verbazingwekkend als in ogenschouw wordt genomen dat het totale drankgebruik in Nederland gedurende de periode die deze onderzoeken bestrijken (1958 tot 1981) maar liefst verdrievoudigd is (van Reek et al., 1984). Deze toename in het totale drankgebruik lijkt zijn weerslag dus niet te vinden in veranderingen in de tijdstippen en lokaties van drinkgewoonten.

Alle hierboven beschreven onderzoeken geven echter slechts een globaal beeld van de drinkgewoonten in Nederland. Kort samengevat komt dit neer op een voorkeur voor drinksituaties in het weekend, de avond, thuis en in het gezelschap van gezinsleden, familie of wrienden. Uit bovenstaande onderzoeken kan niet worden afgeleid hoe deze kenmerken van drinksituaties zich tot elkaar verhouden. Dat er in het weekend en 's avonds meer gedronken wordt, of dat er op die tijden meer mensen drinken is niet in verband gebracht met het gezelschap of de plek waar het drinkgedrag plaatsvond. Er zijn binnen de thuissituatie verschillende mogelijke drinksituaties. Drinkt men alleen tijdens een gezellig bij elkaar zijn met gezin of familie of zijn er ook andere bezigheden waarbij men in de huiselijke sfeer drinkt. Een ander nadeel wan bovenbeschreven onderzoeken is dat er bij vragen naar drinkgewoonten is uitgegaan van gesloten vragen. Dit kan tot gevolg hebben dat situaties die de onderzoeker niet als mogelijke drinksituaties heeft voorzien ook niet naar woren komen in de resultaten wan het onderzoek. Wellicht reflecteren de resultaten enkel de door de onderzoeker verwachte drinkgewoonten.

Hoewel de globale conclusies van bovenbeschreven onderzoeken allen hetzelfde beeld schetsen, 
verschillen de onderzoeken teveel om mogelijke verschuivingen in de drinkgewoonten van de Nederlandse bevolking te kunnen preciseren. Werd er in 1981 vaker 's middags gedronken dan in 1958, werd er meer buitenshuis gedronken of is de verhouding buitenshuis-thuis gellik geblevern?

In dit hoofdstuk zal op grond van de dagboekgegevens een completer en specifieker beeld wan de drinkgewoonten in Nederland worden gegeven. De aard van het gebruikte materiaal staat geen wergaande conclusies omtrent plaats van drinkgedrag of drinkgezelschap toe. Wel kunnen tijdstip waarop en activiteit warbij is gedronken worden gespecificeerd. Op grond van de activiteit kan well iets gezegd worden over plats en gezelschap. Als de drinkgewoonten sinds 1980 niet meer zijn veranderd mag worden verwacht dat een groot deel wan de drinkgelegenheden op de thuisplek platsvinden, in de avonduren wallen en op weekend-dagen. worden gerealiseerd.

\subsection{Vraagstellingen}

De vragen die in cit hoofdstuk zullen worden behandeld komen voort uit bovenstaande omschrijving van de kenmerken wan drinkgewoonten. De allereerste vraag betreft de drinkgelegenheden die als sociale drinkgewoonten kunnen worder aangewezen. Welke drinkgelegenheden in het dagelijks leven kunnen als uitingen van sociale drinkgewoonten worden beschouwd? Bij welke activiteiten wordt gedronken? Op welke tijdstippen wordt gedronken? Zijn er dagen warop meer gedronken wordt dan op andere dagen?

Op grond van het gebruikte materiaal is het mogelijk om een specifieke beschrijving te geven van de situaties waarin drinkgedrag platsvindt dat als sociale gewoonte mag worden beschouwd. In tegenstelling tot boven beschreven onderzoeken kunnen alle mogelijke activiteiten en alle mogelijke tijdstippen gedurende een doorsnee week aan de orde komen en met elkaar in verband worden gebracht. De sociale drinkgewoonten in Nederland worden beschreven aan de hand van de kenmerken van drinksituaties. De kenmerken van de drinksituaties worden vergeleken met resultaten van eerder onderzoek zoals boven beschreven.

De verzameling drinksituaties kan worden opgevat als het total wan situaties in het dagelijks leven waarbinnen alcoholgebruik als een geaccepteerde vorm van gedrag wordt beschouwd. Er mag worden verwacht dat er grote verschillen tussen drinksituaties zullen zijn. Er zijn situaties waturbinnen thet eerder regel dan uitzondering is om aloohol te gebruiken. Gadourek (1963) beschrijft het anbieden wan een drankje door de gastheer als vergelijkbaar met het afnemen van de hoed wanneer men elkaar op straat tegenkomt. Hoewel het dragen van hoeden tegenwoordig nauwelijks meel voorkomt, is dit een duidelijk voorbeeld van een situatie waarin drinken welhaast moet. In dit soort situaties zal de kans op drinkgedrag (drinkers/deelnemers) groot zijn. Ei zullen echter ook situaties zijn waarbinnen deze druk om te drinken ontbreekt. In dit soort situaties is de vrijheid om te beslissen wel of niet te drinken groot en zal de kans op drinkgedrag warschijnijik lager $z$ ïnn.

De kans op drinkgedrag in een drinksituatie is op deze wijze zowel bepalend voor als het resultaat van de individuele gedragskeuzes van sociale actoren. Drinksituaties zullen worden getypeerd naar de kans op drinkgedrag in die situaties. Er zal worden onderzocht hoe de kenmerken van de situaties (dag van de week, tijdstip en activiteit) samenhangen met deze kans op drinkgedrag.

De selectie van adequate gedragswormen binnen een situatie is niet alleen aan die situatie gebonden. Ook kenmerken van de sociale actor spelen hierbij een rol. Een volgende vraag die 
hier wordt gesteld is of er naar gelang consumptieniveau werschillen zijn in de wijze warop drinkers gebruik maken van het aanbod van drinksituaties. In algemenere termen: welke wariaties zijn er in drinkgewoonten van sociale actoren naar gelang hun consumptieniveat.

Zijn de hogere totale drinkfrequentie en/of kwantiteit per keer die zware drinkers van matige of lichte drinkers onderscheiden algemene kenmerken van deze drinkers die in alle drinksituaties in gelijke mate tot uiting komen, of is er een verschil in situaties waarbinnen zware drinkers drinken en die waarbinnen lichte drinkers drinken. Indien zware drinkers vaker drinken dan lichte drinkers, doen ze dat dan binnen alle mogelijke drinksituaties of is de hogere drinkfrequentie het gevolg van het drinken in situaties waarbinnen lichte drinkers geen alcohol gebruiken? Terwijl de (extreem) lichte drinkers zich bijwoorbeeld zullen beperken tot het kerstdiner en het verjaardagsfeest als contexten waarbinnen wordt gedronken zouden (extreem) zware drinkers bijvoorbeeld ook drinken tijdens het autowassen als gepast kunnen beschouwen. Hoewel de hier gebruikte onderzoeksgegevens geen definitieve conclusies toestaan kunnen uit mogelijke verschillen tussen zware en lichte drinkers aanwijzingen over de wijze waarop individuen hun drinkgedrag intensiveren worden afgeleid.

In paragrafen 3.3 en 3.4 wordt achtereenvolgens beschreven hoe de definitie van drinksituaties tot stand is gekomen en welke de kenmerken van deze situaties binnen de mannelijke en vrouwelijke populatie zijn. Verschillen in drinkgedrag tussen zware en lichte drinkers wordem gepresenteerd in paragraaf 3.5 met ook hier afzonderlijke analyses voor mannen en vrouwen.

\subsection{Methode}

In deze paragraaf zullen de sociale drinkgewoonten worden beschreven en zal worden onderzocht hoe kenmerken van drinksituaties samenhangen met de kans op drinkgedrag in die situaties. De sociale drinkgewoonten zullen worden beschreven aan de hand van de kenmerken van drinksituaties. Welke situaties als drinksituaties mogen worden opgevat wordt afgeleid uit de kenmerken van de daadwerkelijk gerealiseerd drinkgelegenheden. De drinkgelegenheden worden beschreven naar de concrete omstandigheden waarbinnen wordt gedronken. Eerst wordt onderzocht binnen welke tijdsperiodes drinkgedrag als een gepast gedrag mag worden beschouwd. Daarna wordt nagegaan bij welke activiteiten in eerder vastgestelde periodes drinkgedrag gepast wordt geacht. De analyse-eenheden die in deze paragraaf worden gebruikt zijn achtereenvolgens tijdsperiodes en drinkgelegenheden.

Er zijn twee argumenten op grond waarvan het totaal aan gerealiseerde drinkgelegenheden kan worden gereduceerd tot een minder grote verscheidenheid aan drinksituaties. Ten eerste zal niet elke in tijdstip of activiteit verschillende context ook als verschillend worden ervaren. Regelmatigheden in gedrag, zowel binnen als tussen personen, komen onder andere voort uit het feit dat socialle actoren niet elke situatie als een nieuwe unieke omstandigheid beleven en definiëren, maar de waargenomen aspecten van die omstandigheid classificeren in bepaalde "ideaal-typen" (Gerhardt, 1971). Wanneer de contexten waarin drinkgelegenheden worden gerealiseerd niet van elkaar verschillen met betrekking tot de regels voor alcoholgebruik behoren deze contexten tot hetzelfde ideal-type, kunnen ze als eenzelfde drinksituatie worden opgevat.

Ten tweede wordt er hier vanuit gegaan dat uit het objectief waarneembare gedrag van sociale actoren afgeleid kan worden welk gedrag gepast wordt geacht. De meeste mensen houden zich het grootste deel van de tijd aan de regels (Giddens, 1984). Op grond van dit laatste kan gesteld worden dat gedrag als 'normaal" of gepast mag worden beschouwd wanneer het met een zekere 
frequentie openlijk voorkomt binnen een populatie.

In deze paragraaf wordt onderzocht binnen welke contexten drinkgelegenheden worden gerealiseerd. Vervolgens zal worden beschreven welke contexten tot dezelfde drinksituaties mogen worden gerekend.

In het gebruikte onderzoeksmaterial kunnen drie kenmerken van contexten waarin drinkgelegentieden worden gerealiseerd, worden onderscheiden: dag van de week, tijdstip en primaire activiteit. Theoretisch zouden er dus 7 (dagen van de week) X 96 (tijdstippen/kwartieren) X 27 (activiteiten) $=18144$ verschillende drinkgelegenheden per persoon kunnen worden onderscheiden.

Behalve het feit dat er in het materiaal niet zoveel verschillende drinkgelegenheden voorkomen, omdat niet op alle tijdstippen in alle activiteiten is geparticipeerd en gedronken, is het ook weinig realistisch om een dusdanig gedetailleerd onderscheid tussen drinkgelegenheden te veronderstellen. De beoordeling van alcoholgebruik als een social geaccepteerde vorm van gedrag zal waarschijnlijk weinig verschillen bij het televisie kijken op dinsdagavond om 20.30 uur of op dinsdagavond 20.45 uur. Hoe gedetailleerd het verschil in de definitie van situaties moet zijn om te kunnen spreken van werschillen in werwachtingen (normen, regels) van drinkgedrag kan op grond wain theoretische owerwegingen niet worden bepaald. Hier wordt uitgegaan wan de empirische gegevens. Eerst wordt onderzocht tijden drinken als een 'normaal' verschijnsel mag worden beschouwd. Daarna wordt onderzocht bij welke activiteiten op die tijden, drinken als een sociale geaccepteerd gedrag mag worden beschouwd.

\subsubsection{Variaties in drinkgedrag naar tijdstip}

Om tot een concrete beschrijving van drinksituaties te komen is eerst onderzocht hoe het drinkgedrag gespreid is over de uren van de dag en de dagen van de week. Hiertoe is een grafiek van het aantal drinkers per uur gecreëerd. In figuur 3.3.1 is voor de gehele dagboekweek en voor de gehele populatie het aantal drinkers per uur weergegeven.

Tabel 3.3.1

Weekritme in proportie drinkers (\%) op piektijden per dag.

\begin{tabular}{|c|c|c|c|c|}
\hline \multirow{3}{*}{$\frac{\text { Dag }}{\text { Zondag }}$} & \multicolumn{4}{|c|}{ Piektijden } \\
\hline & \multicolumn{2}{|c|}{18.00 Uur } & \multicolumn{2}{|c|}{23.00 Uur } \\
\hline & 115 & $(13 \%)$ & 208 & $(23 \%)$ \\
\hline Matandag & 53 & $(6 \%)$ & 174 & $(19 \%)$ \\
\hline Dinsdag & 60 & $(7 \%)$ & 173 & $(19 \%)$ \\
\hline Woensdag & 62 & $(7 \%)$ & 199 & $(22 \%)$ \\
\hline Donderdag & 62 & $(7 \%)$ & 188 & $(21 \%)$ \\
\hline Vrijdag & 71 & $(8 \%)$ & 242 & $(26 \%)$ \\
\hline Zaterdag & 83 & $(9 \%)$ & 299 & $(33 \%)$ \\
\hline Totalle $\mathrm{N}$ & \multicolumn{2}{|c|}{$493(100 \%)$} & \multicolumn{2}{|c|}{$423(100 \%)$} \\
\hline
\end{tabular}


Met uitzondering van zondag vertoont de spreiding van het aantal drinkers per uur op alle dagen eenzelfde patroon. De eerste drinkers verschijnen rond $8.00-9.00$ uur 's ochtends. Vanaf 14.00 uur stijgt het drankgebruik naar een piek om 18.00 uur. Dan daalt het drankgebruik tot 20.00 uur waarna het naar een hoge piek stijgt. Deze piek ligt voor alle dagen op 23.00 uur. De hoogte van deze pieken op de verschillende dagen is weergegeven in tabel $3.3 . \mathrm{l}$.

Figuur 3.3.1

Aantal drinkers per uur tijdens de dagboekweek.

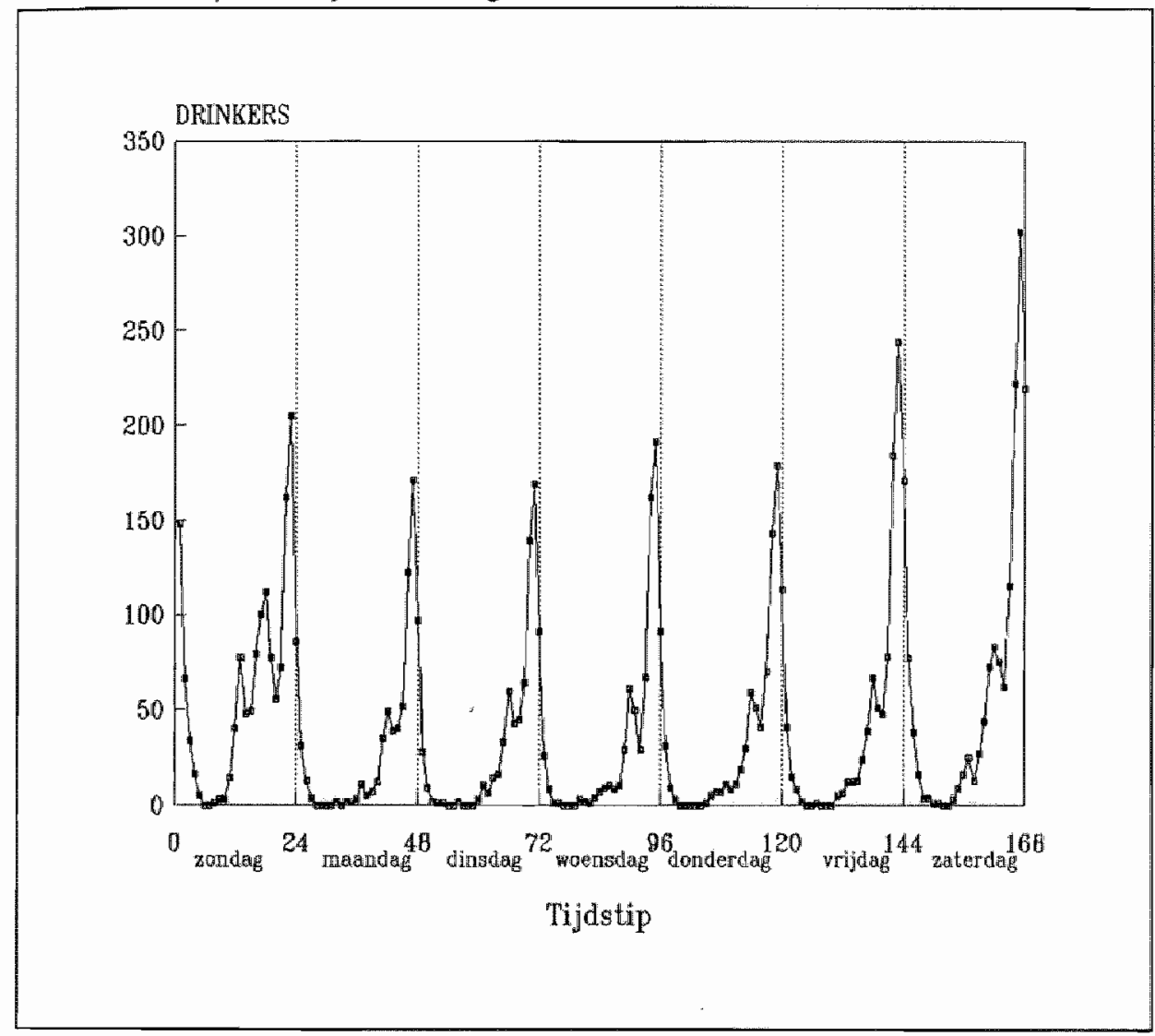

Zoals reeds gesteld wijkt de verdeling van de drinkers over de uren van de dag op zondag duidelijk af van die op de andere dagen. Op zondag blijkt er een extra piek in het drankgebruik te zijn en wel om 13.00 uur ( 78 drinkers). De pieken om 18.00 uur (115 drinkers) en om 23.00 uur (208 drinkers) doen zich op zondag ook voor. De piek om 18.00 uur is op zondag beduidend hoger dan op andere dagen. 
Op grond van bovenstuande zijn drie periodes in het etmaal te onderscheiden:

1) de periode van 06.00 utr' 's vchtends tot 14.00 uur 's middags tijdens welke niet of natwelijks wordt gedronken (behalve op zondag).

2) De periode tussen 14.00 uur "s middags en 20.00 uur "s avonds waarin de eerste piek in het drankgebraik valt.

3) De periode van 20.00 uur 's avonds tot 06,00 uur 's ochtends warin de tweede piek in het drankgebruik valt.

Op basis van het totaal aantal drinkers per periode is voor mannen en vrouwen afzonderlijk vastgesteld binnen welke periodes alcoholgebruik als een 'normaal' verschijnsel mag worden beschouwd. Daar de temporele condities voor alle leden van de populatie dezelfde zijn (iedereen heeft 24 uur per dag en 7 dagen per week ter beschikking) is de frequentie van drankgebruik per periode hiertoe voldoende. Het aantal drinkers per periode is weergegeven in tabel 3.3.2.

Tabel 3.3 .2

Weekritme in proportie drinkers per periode per dag voor mannen en vrouwen afzonderlijk.

\begin{tabular}{|c|c|c|c|c|c|c|}
\hline & \multicolumn{2}{|c|}{$\begin{array}{c}\text { Ochtend } \\
(06.00-14.00)\end{array}$} & \multicolumn{2}{|c|}{$\begin{array}{c}\text { Middag } \\
(14.00-20.00)\end{array}$} & \multicolumn{2}{|c|}{$\begin{array}{l}\text { Avond } \\
(20.00-06.00)\end{array}$} \\
\hline & mannen & vrouwen & mannen & vrouwen & mamnen & vrouwen \\
\hline Zondag & 18 & 11. & 35 & 22 & 43 & 25 \\
\hline Maandag & 3 & 2 & 16 & 9 & 40 & 20 \\
\hline Dinsdag & 2 & 2 & 19 & 12 & 39 & 24 \\
\hline Woensdag & 4 & 2 & 16 & 12 & 42 & 24 \\
\hline Donderdag & 5 & 3 & 18 & 13 & 42 & 25 \\
\hline Vrijdag & 5 & 1 & 20 & 15 & 51 & 35 \\
\hline Zaterdag & 7 & 4 & 27 & 17 & 58 & 39 \\
\hline
\end{tabular}

Drinkgedrag is als een 'uitzonderlijk' gedrag beschouwd binnen die periodes waarin minder dan $5 \%$ van de populatie drinkt. Op grond van dit criterium en de gegevens in tabel 3.3 .2 is bepald dat tijdens de ochtenden van de weekdagen, en binnen de vrouwelijke populatie ook tijdens de zaterdagochtend, drinkgedrag niet als een 'normaal' gedrag mag worden beschouwd. Het drinken tijdens deze periocles wordt niet verder gespecificeerd.

Het drinkgedrag in Nederland wordt gekenmerkt door een sterk dagelijks ritme. Zowel 's middags als "s avonds zijn er pieken in het aantal drinkers per uur. De pieken in de avonduren zijn hoger dan die in de middag. De op grond van de literatuur te werwachten verschillen tussen week en weekend-clagen komen met name tot uiting in verschillen in de hoogte van de pueken in het gebruik op de verschillende dagen. Er worden hogere pieken gevonden op vrijdag- en zaterdagavond en op zaterdag- en zondagmiddag. 
Er zijn voor mannen 16 en voor vrouwen 15 afzonderlijke periodes in de week onderscheiden waarbinnen drinkgedrag als een 'normal' verschijnsel mag worden beschouwd. Binnen elk van deze periodes zal worden onderzocht welke de naar activiteit gedefinieerde drinkgelegenheden zijn waarin drinkgedrag als 'normaal' verschijnsel is te beschouwen. Daarbij wordt opnieuw van een empirisch criterium uitgegaan.

\subsubsection{Variaties in drinkgedrag naar activiteit per periode}

Ter bepaling van de normaliteit van alcoholgebrulk binnen periodes is uitgegaan van het aantal mensen dat binnen die periode activiteiten met drinkgedrag combineert. In theorie kunnen er per periode 27 verschillende drükgelegenheden (activiteiten) voorkomen. Gelegenheden warbij minder dan $1 \%$ wan de populatie drinkt worden als witzonderlijk beschouwd. In concreto betekent dit dat indien, in ons onderzoek, minder dan 5 mannen of 5 vrouwen tijdens een periode een activiteit met drinkgedrag combineert dit als uitzonderlijk of ongewoon drinkgedrag wordt beschouwd.

In bujlage 3.1 is a angegeven welke de social geaccepteerde drinkgelegenheden zijn, hoe valk dergelijke gelegenheden voorkomen en hoeveel mensen zulke gelegenheden met arinkgedrag combineren. Bij de mannen kunnen er 195 en bij de vrouwen 95 verschillende sociatl geaccepteerde drinkgelegenheden worden onderscheiden. Hoewel binnen de mannelijke populatie drinkgedrag op zaterdagochtend als een 'normaal' gedrag was gedefinieerd blijken w geen activiteiten te zijn warbij op de zaterdagochtend meer dan $1 \%$ van de mannen drinkt. Alle drinkgedrag op zaterdagochtend wordt daarom als 'abnormaal' beschouwd.

\subsection{De definitie en beschrijving van drinksituaties}

In de mannelijke populatie kunnen 195 verschillende drinkgelegenheden worden onderscheiden. Elke drinkgellegenheid wordt gekenmerkt door een unieke combinatie van dag (dag van de week), tijd (periode van de dag) en activiteit waarbij tenminste $1 \%$ van de populatie drinkt. Nu is de vraag of de wisselende contexten warin al deze drinkgelegenheden worden gerealiseerd, door de sociale actoren ook daadwerkelijk als verschillende drinksituaties worden beoordeeld. In concreto: zijn de regels voor drinkgedrag verschillend tussen bijwoorbeeld de omstandigheden maandagavond televisie-kijken en dinsdagavond televisie-kijken. Het ligt voor de hand om te verwachten dat niet alle contexten wat betreft deze regels van elkaas" verschillen. Of, met andere woorden, dat verschillende omstandigheden als eenzelfde soort situatie worden beleefd. Verschillen in de beoordeling van de mate van gepastheid van drinkgedrag in verschillende situaties zullen tot uiting komen in verschillen in de empirisch warneembare kans op drinkgedrag in die situaties. Hoe groot verschillen in kans op drinkgedrag moeten zijn om verschillen in perceptie te mogen veronderstellen kan op theoretische gronden niet worden bepaald. Er wordt hiler gestreefd naar een specifieke beschrijving wan drinksituaties. Situaties worden als verschillend beschouwd indien ze (statistisch) verschillen in kans op drinkgedrag.

\subsubsection{Definitie van drinksituaties}

Omstandigheden warin drinkgelegenheden zijn gerealiseerd zijn als behorende tot eenzelfde, ideaal-typische, situatie gedefinieerd wanneer: 
1) die gelegenheden binnen een gelifksoortige periode plaatsvinden (bujvoorbeeld de miiddag) èn

2) de clefinierende activiteit dezelfde üs èn

3) de kans op drinkgedrag in die omstandigheden niet verschilt.

De kans op drinkgedrag in een bepalde context kan op twee manieren worden berekend:

1) als het aantal mensen dat in zo'n context drinkt (DN) gedeeld door het aantal mensen dat in die context participeert (N).

2) als het aantal kwartieren dat er in die context gedronken wordt gedeeld (DT) het aantal kwartieren dat in die context wordt besteed $(T)$.

In dit laatste geval zou de kans op alcoholgebruik bij een bepaalde expositie (in kwartieren) worden berekend. Aangenomen wordt dat regels voor drinkgedrag meer van toepassing zijn op het al dan niet drinken binnen een gelegenheid dan op de hoeveelheid die binnen die gelegenheid wordt gedronken (Schippers, 1981). Daarom is deze benadering van de kans op drinkgedrag niet gekozen. Dat wil niet zeggen dat deze benadering geen zinvolle informatie kan verschaffen. Het aantal kwartieren dat er in een situatie is gedronken, of beter dat er alcoholgebruik is gerapporteerd, is vanwege de aard van het onderzoeksinstrument praktisch synoniem met het aantal glazen dat is gedronken. De kans dat er gedronken wordt, uitgedrukt in het aantal kwartieren gedronken gedeeld door het aantal kwartieren deelname is daarmee een indicatie voor de intensiteit wan het alcoholgebruik binnen een context.

Drinkgelegenheden zijn dus als gelijksoortig (eén drinksituatie) beschouwd wanneer ze vergelijkbaar zijn met betrekking tot primaire activiteit en tijdsperiode en wanneer de kansen op drinkgedrag, berekend als het aantal drinkers binnen die context gedeeld door het aantal deelnemers niet significant van elkaar verschillen.

Omdat alle drinkgelegenheden door dezelfde respondenten zijn gerapporteerd, mogen de kansen op drinkgedrag tijdens die gelegenheden niet als statistisch onafhankelijk worden beschouwd. Of de kansen op drinkgedrag van elkaar verschillen is dan ook onderzocht met een toets gebaseerd op de conditionele afhankelijkheid wan de gelegenheden (Guilford, 1965). Drinkgelegenheden die niet significant van elkaar verschillen in de kans op drinkgedrag en voldoen aan de criteria genoemd onder 1) en 2) zijn beschouwd als realisaties van drinkgedrag in eemzelfde ideaal-typische drinksituatie. Wanneer meer dan twee drinkgelegenheden tot dezelfde situatie zujn gerekend betekent dit dat al deze gelegenheden onderling niet werschillen in de kans op drinkgedrag.

Al met al kunnen op deze wijze binnen de mannelijke populatie 60 en binnen de wrouwelijke populatie 34 verschillende drinksituaties worden onderscheiden.

In tabellen 3.4 .1 en 3.4 .2 is angegeven welke activiteit, periode en combinatie van dagen elk der drinksituaties kenmerkt. Verder is in deze tabellen het aantal deelnemers per drinksituatie en de kans dat een deelnemer tijdens de dagboekweek in die situatie drinkt, weergegeven.

De kans op gerealiseerd drinkgedrag varieert van .02 (werk op woensdagmiddag) tot .87 (café bezoek op zaterdagavond) Het aantal deelnemers aan drinksituaties (ook degenen die niet drinken) loopt uiteen van 12 (café-bezoek op donderdagmiddag) tot 491 (eten op de middagen van de weekdagen). 


\subsubsection{Beschrijving van drinksituaties}

De literatuur over de aard der drinkgewoonten in Nederland rechtwaardigt de verwachting dat de sociale drinkgewoonten met name in de avonduren en op weekend-dagen voorkomen en dat ze in de thuissituatie en in het gezelschap van gezin, familie of vrienden plaatsvinden.

De in het voorafgaande gepresenteerde drinksituaties zijn beschouwd als een weergave wan de drinkgewoonten in Nederland. Op grond van de berekende kans op drinkgedrag in drinksituaties kunnen uitspraken gedaan worden over het relatieve belang van tijd en activiteit voor de sociale drinkgewoonten. Daar alleen tijd en activiteit als definierende kenmerken zijn gebrukt kunnen alleen indirecte conclusies over de plaats en het gezelschap worden getrokken.

\section{De mannen}

Zoals gezegd zijn drinksituaties gedlefinieerd als alle situaties (combinatie var dag tijdstip en activiteit) waarbinnen drinkgedrag als een gepast gedrag mag worden beschouwd. Zowel tijdstip als activiteit zijn factoren die op de kans op drinkgedrag binnen situaties van invloed zijn. Enerzijds zijn er 'natte' dagen en tijden (weekend-dagen en avonden) anderzijds zijn er 'natte" activiteiten. Zelfs activiteiten waarbij op zich de kans op drinkgedrag gering is zijn nog als drinksituaties aangewezen doordat ze op natte tijden net genoeg drinkers bleken te vertonen. Anderzijds zijn er droge tijden waarop toch drinksituaties gewonden zijn, dat waren dan situaties gekenmerkt door activiteiten met een redelijk hoge kans op drinkgedrag. Voorbeelden zijn televisie kijken, relaxen en visite op de zondagochtend.

Achtereenvolgens zal nu beschreven worden hoe de kans op drinkgedrag in drinksituaties varieert met tijd, dag van de week en activiteiten.

Over het algemeen is de kans op drinkgedrag bij een activiteit "s avonds groter dan "s middags. Dat er "s avonds meer gedronken wordt is dus niet alleen terug te voeren op een verschil in bezigheden tussen de middag en de avond, mar is ook voor een deel het resultat van een grotere geneigdheid om te drinken in de avonduren. Voor bijna alle activiteiten warbij drinkgedrag 's avonds als normal mag worden beschouwd, is de kans op drinkgedrag redelijk tot hoog $(\mathrm{p}>20)$. De enige activiteit waarbij 's middags een kans van die grootte gevonden werd was visite en wel op zaterdag of zondagmiddag $(\mathrm{p}=.22)$. Ook wisite op zondagochtend wordt gekenmerkt door tamelijke hoge kans op drinkgedrag $(p=24)$. Voor alle andere activiteiten is de kans op drinkgedrag 's middags laag. Activiteiten warbij de kans op drinkgedrag 's avonds laag is waren slaap, werk, persoonlijke verzorging en hobby's. Met name slap en persoonlijke verzorging zijn in de analyse betrokken omdat ze een dusdanig groot aantal deelnemers kennen dat ze ondanks een lage kans op drinkgedrag toch als drinksituaties zijn gedefinieerd.

Aanwijzingen voor weekenddrinken kunnen worden afgeleid uit verschillen in de kans op drinkgedrag tussen weekdagen en weekend-dagen. Met name op de vrijdag-en zaterdagavorid en de zaterdag- en zondagmiddag blijken relatief veel mensen te drinken. Ook het in vergelijking tot andere dagen hoge aantal drinkers op zondagochtend is een indicatie voor een grotere geneigdheid tot drinkgedrag in het weekend. Zo is bijwoorbeeld de kans op drinkgedrag. bij visite op zaterdagawond groter dan op andere avonden. De enige ochtend warop drinksituaties voorkomen is de zondagochtend. Over het algemeen is 's middags op visite gaxn een vrij 'droge' situatie (maar wel nog een drinksituatie). Dat is echter niet zo op zaterdag-en zondagmiddag. Er zijn echter ook activiteiten die wat betreft de kans op drinkgedrag niet gevoelig zijn voor de dag van de week. Voorbeelden hiervan zijn café-bezoek "s middags, "s avonds lezen of sociale contacten met huisgenoten. Bij de activiteit relaxen 's avonds onderscheidt zich vrijdag van de andere dagen door een hogere kans op drinkgedrag. 
De zondagavond onderscheidt zich in de meeste gevallen niet van de avonden wan doordeweekse dagen. Dit is te begrijpen als een "voorbereiding" op de maandag. Met betrekking tot de kans op drinkgedrag mag de zondagavond in feite niet tot het weekend worden gerekend. Hiervoor komen eerder de vrijdagmiddag en -avond in aanmerking. Deze onderscheiden zich wan de doordeweekse dagen voor de situaties sociale contacten met huisgenoten, café-bezoek en relaxen. De vrijdag onderschieidt zich bij deze activiteiten ook van de zaterdag en de zondag. 
TABEL 3.4 .1

Drinkstuaties, kans op orinkgeorag en aandal dewemers bif de manmen

\begin{tabular}{|c|c|c|c|c|}
\hline aktiviltein" & periote & dag(en) & $p^{2}$ & $N$ \\
\hline \multicolumn{5}{|l|}{ Droge sifuaties } \\
\hline SLAAP & awond & wo, $v r$ & .02 & 492 \\
\hline WERK & midjag & wo & 02 & 285 \\
\hline PERS. VERZ. & awond & 20 & .03 & 150 \\
\hline ETEN & ochtend & 20 & .03 & 453 \\
\hline RELAXEN & ochtend & 20 & .04 & 168 \\
\hline MASSA MEDL & middag & ma tol zia & .06 & 422 \\
\hline RELAXEN & middag & $m a, d_{0}$ wo $v$ & .00 & 294 \\
\hline LEZEN & ochtend & 20 & .06 & 98 \\
\hline HUISHOUDEN & middag & $\mathrm{ma}, \mathrm{di}_{\mathrm{i}} \mathrm{za}$ & .07 & 282 \\
\hline MASSA MEDHA & middag & 20 & of & 301 \\
\hline SOC. KONT. & ochtend & 20 & .08 & 80 \\
\hline SOC. KONT. & middag & 20 lot wo, 2a & .08 & 205 \\
\hline LEZEN & middag & zo tot do & .08 & 265 \\
\hline MASSA MEDHA & ochtend & 20 & .09 & 99 \\
\hline HOBBIES & middag & 20 en $2 a$ & .09 & 150 \\
\hline WERK & middag & ma,di,do,wi & .09 & 329 \\
\hline ANDEFS & middag & ma, do tot za & .10 & 154 \\
\hline SOC. KONT. & middag & ve & .11 & 89 \\
\hline RELAXEN & middag & $z a, d 0,2 a$ & .11 & 317 \\
\hline WERK & awond & $\mathrm{di}_{4} \mathrm{do}$ & .12 & 98 \\
\hline KARWEIT.JES & awond & wo & .13 & 38 \\
\hline ETEN & middag & ma lot vi & .14 & $49 甘$ \\
\hline ETEN & middag & zo en za & .15 & 483 \\
\hline HOBBIES & awond & za & .15 & 34 \\
\hline VISITE FAM. & middag & ma tot vr & .17 & 190 \\
\hline WISITE KEN!. & middag & ma tot vr & .17 & 187 \\
\hline VISITE FAM. & middag & $2 \mathrm{a}^{\mathrm{j}}$ & .20 & 122 \\
\hline UIT ANDEAS & middag & 20 & .20 & 61 \\
\hline HOBBIES & awond & 20, di lot vr & .20 & 171 \\
\hline \multicolumn{5}{|l|}{ Medium sifualies } \\
\hline MOBBIES & awond & ma & .21 & 61 \\
\hline VISITE KEN. & midiag & zo en za & .22 & 143 \\
\hline VISITE KEN. & ochtend & 20 & .22 & 54 \\
\hline RELAXEN & avond & zo tot do.za & .22 & 247 \\
\hline ETEN & avond & zo tot za & .22 & 200 \\
\hline ANDERS & avond & $z 0, \mathrm{di}, \mathrm{do}, \mathrm{vr}, \mathrm{za}$ & .23 & 180 \\
\hline VISITE FAM. & ochtend & $\mathrm{zO}$ & .24 & 104 \\
\hline VISITE FAM. & avond & ma & .26 & 31 \\
\hline OAGANISATIE & avond & di & .26 & 19 \\
\hline LEZEN & awond & 20 tol $2 a$ & 27 & 222 \\
\hline ANDEAS & awond & wo & 31 & 36 \\
\hline RELAXEN & avond & $v r$ & .32 & 81 \\
\hline VISITE FAM. & midolag & 20 & .35 & 133 \\
\hline VISITE KEN. & avond & wo & .35 & 52 \\
\hline SOC. KONT, & awond & $201012 a$ & .38 & 1.90 \\
\hline CAFE/BAR & middag & má & 38 & 13 \\
\hline MASSA MEDIA & awond & 20 tol di,do & .40 & 461 \\
\hline MASSA MEDIA & awond & wo,vr,za & 46 & 425 \\
\hline PARTICIPATIE & awond & diver & 46 & 24 \\
\hline WISITE FAM & awond & 20, dilot $\mathrm{vr}$ & .49 & 175 \\
\hline \multicolumn{5}{|l|}{ Nalte siluaties } \\
\hline VISITE KEN. & avond & 20 tol dido,wr & .52 & 204 \\
\hline KANTINE & middag & $20, \mathrm{Za}$ & .54 & 35 \\
\hline CAFE/BAA & middag & do & .55 & 11 \\
\hline VISITE FAMI. & avond & $2 \mathrm{a}$ & .55 & 78 \\
\hline CAFE/BAR & middag & 20, di, wo, vr, $\mathrm{za}$ & .64 & 61 \\
\hline KANTINE & awond & $\mathrm{ma}_{\mathrm{i}} \mathrm{dli}, \mathrm{do}$ wr & 65 & 20 \\
\hline VISITE KEN. & avond & $2 a$ & 65 & 86 \\
\hline CAFE/BAR & middag & $\mathrm{do}$ & .67 & 12 \\
\hline CAFE/BAR & avond & zo tot dido & 67 & 61 \\
\hline CAFE/BAR & avorid & WT & .96 & 37 \\
\hline CAFE/BAA & avond & $z a$ & .87 & 55 \\
\hline
\end{tabular}


Dit suggereert dat de verhoogde kans om bij bovenstaande activiteiten te drinken op vrijdag. samenhangt met de overgang van week naar weekend. Ook bij televisie-kijken blijkt de kans op drinkgedrag op vrijdag en zaterdagavond hoger te zijn dan op zondagavond en de andere avonden. Bij de mannen is dit eveneens zo voor de woensdagavond, wat door ervaringsdeskundigen wordt toegeschrewen aan een hogere kars op drinken tijdens het kijken naar Europa-cup voetbal dat woensdagavond wordt uitgezonden. Dit is echter slechts een gissing.

Niet verwonderlijk is dat het bezoek aan openbare drinkgelegenheden (café, kantine) gekenmerkt wordt door een hoge kans op drinkgedrag. Dit is zowel 's avonds als 's middags het geval. Alleen het café-bezoek op maandagavond wijkt af door een lagere kans op drinkgedrag $(p=38)$. Geconcludeerd zou kunnen worden dat de activiteit weliswaar nat is (hogere kans op drankgebruik) maar het tijdstip niet. De enige andere activiteit waarbij een grote ( $p>50)$ kans op drinkgedrag geconstatteerd kon wordien was visite en wel op zaterdagavond.

\section{De vrouwen}

Binnen de vrouwelijke populatie werden 34 drinksituaties 'ontdekt'. Dat is de helft van het aantal in de mannelijke populatie. Dit verschil zou voort kunnen komen uit een grotere overeenkomst in drinkgelegenheden op verschillende dagen waardoor meer gelegenheden beschouwd zijn als behorend tot een drinksituatie. Het zou evenwel ook teweeg worden gebracht een kleinere kans op drinkgedrag bimnen bepaalde contexten waardoor deze binnen de vrouwelijk populatie niet als sociaal geaccepteerde drinkgelegenheden gedefinieerd zijn. Dit laatste blijkt vooral het geval. Over het algemeen is de kans op drinkgedrag binnen vergelijkbare situaties in de vrouwelijke populatie lager dan in de mannelijke populatie. Situaties, die bij de mannen wel en bij de vrouwen niet als acceptabele drinksituaties zijn gedefinieerd waren 's middags of 's avonds werk, 's avonds slatap, persoonlijke verzorging, vereniging of organisatie, 's middags en 's avonds kantinebezoek, 's middags uit anders en zondagochtend sociale contacten met huisgenoten, televisie-kijken, lezen of relaxen. Alleen 's avonds uit anders is een drinksituatie die bij de vrouwen wel maar bij de mannen niet werd ontdekt. De variaties in kans op drinkgedrag binnen de vrouwelijke populatie zijn vergelijkbaar met die bij de mannen. De voorkeur voor de avond als tijd om te drinken komt naar voren wit het feit dat er 's middags minder activiteiten zijn die drinksituaties kenmerken en dat bij die activiteiten, die zowel 's avonds als 's middags drinksituaties kenmerken de kans op drinkgedrag 's avonds duidelijk hoger is.

Ook in de vrouwelijke populatie worden indicaties voor weekend-drinken gevonden. De vrijdagen de zaterdagavond onderscheiden zich van de andere avonden door een hogere kans op drinkgedrag bij café-bezoek, visite, uit anders, lezen, televisie-kijken en anders. Geen onderscheid werd gevonden voor relaxen, hobby's en eten. Onderscheid tussen de zondag en weekdagen werd gevonden voor de middag en wel bij de activiteiten eten (een hogere kans op drinkgedrag op zondag en zaterdag) en visite (een hogere kans op zondag). Drinksituaties die op zondagochtend vallen worden bij de vrouwen gekenmerkt door eten en visite. De ochtenden zoals hier gedefinieerd bestrijken de periode van 6 uur 's ochtends tot 2 uur 's middags. Drinken bij het eten op zondagochtend heeft betrekking op het "vroege" middagmaal. 
aktiviteit"

Droge sutuaties"

ETEN

RELAXEN

HOBBYS

VISITE KEN.

MASSA MEDLA

LEZEN

SOC. KONT.

RELAXEN

HUISHOUDEN

MASSA MEDIA

ETEN

LEZEN

VISITE FAM.

ETEN

VISITE FAM.

VISITE KEN.

LEZEN

VISITE FAM.

HOBBY'S

RELAXEN

Mediun simaties

ETEN

SOC. KONT.

MASSA MEDIA

VISITE FAM.

MASSA MEDLA

ANDERS

VISITE KEN.

VISITE FAM.

VISITE KEN.

UIT ANDERS

CAFE/BAR

CAFE/BAR

Natre situaties

CAFE/BAR

CAFE/BAR periode

dag(en)

zo

do

za

$\mathrm{Vr}$

Zo,vr,za

zo, di,vr

za

$\mathrm{ZO}, \mathrm{di}, \mathrm{wO}, \mathrm{Vr}$

di,wo, do, vr, za

di

ma,di,wo,do, wr

zo tm do

ma,vr,za

$\mathrm{zO}, \mathrm{Za}$

zo

zo,wo,do,za

$\mathrm{vr}, \mathrm{za}$

zo

zo, ma,di,wo,vr,za

zo tm za $p$

.02

.04

.06

.06

.06

.07

.08

.09

.09

10

.11

.12

.12

.13

.13

.14

.15

.16

.18

.18

.21

.21

.22

.23

.23

.24

31

.32

.40

.41

.42

.46

59

.64
390

142

105

311

200

62

290

421

254

420

236

196

417

143

233

127

110

222

258

1.21

122

342

154

395

25

180

94

126

32

12

22

N

anvond

middag

zo,do

zo,di,do

39

$\mathrm{vr}, \mathrm{za}$

53

' voor uitgebreidere omschrijving van activiteiten zie bijlage 2.2

${ }^{2} \mathrm{p}=$ aantal drinkers (DN) per situatie/deelnemers (N) per situatie. 


\section{Verdeling van drankgebruik over lokaties}

Op grond van het totale drankgebruik en het totaal aantal gerealiseerde drinkgelegenheden per activiteit kan een beeld worden gevormd over het belang van de lokatie voor de sociale drinkgewoonten. Drinksituaties gekenmerkt door activiteiten binnenshuis (waaronder visite) en activiteiten buitenshuis (het bezoek aan openbare drinkgelegenheden, werk en overigen') kunnen worden onderseheiden.

De mannen rapporteren in total 71.13 consumpties, deze werden binnen 2798 drinkgelegenheden gerealiseerd. Visite als activiteit nam in totaal 1638 consumpties voor haar rekening, de overige activiteiten binnenshuis 3227 consumpties. Tezamen is dat $68 \%$ wan het totale drankgebruik in de dagboekweek. Bij het bezoek aan openbare drinkgelegenheden werden 1393 consumpties gerapporteerd, daarvan 1125 bij café-bezoek. Dit is $20 \%$ van het totaal. De activiteit werk nam 181 consumpties ofwel $3 \%$ van het totale drankgebruik voor haar rekening. Bij de vrouwen speelt arbeid als kenmerkende activiteit voor drinksituaties geen rol van betekenis. Vrouwen dronken in de thuissituatie 1325 (53\% van het totaal) en bij visite 695 alcoholische consumpties (27\% van het totaal). In de huiselijke sfeer wordt dus $80 \%$ van de totale consumptie gerealiseerd. In de openbare drinkgelegenheden nog eens $12 \%$ ofwel 296 consumpties.

De activiteit waarbij het meest gedronken wordt in de huiselijke sfeer is zowel voor mannen als voor vrouwen televisie-kijken. Bij de vrouwen verdwijnt $18 \%$ (441 consumpties) en bij de mannen $20 \%$ (1441 consumpties) van de totale consumptie bij de buis door de kelen.

\subsection{Drinkgewoonten en zwaarte van het drinkgedrag}

In de voorafgaande paragrafen zijn de sociale drinkgewoonten in Nederland beschreven aan de hand wan de kenmerken van drinksituaties. De kenmerken van deze situaties (dagsoort, tijdstip, en activiteit) reflecteren de regels omtrent drinkgedrag. Ze geven aan binnen welke situaties alcoholgebruik als een geaccepteerde vorm van gedrag mag worden beschouwd.

Hen totale drankgebruik van een individu is de som van zijn of haar gebruik in alle mogelijke drinksituaties plus alle "abnormale" drankgebruik. Er bestaan grote verschillen tussen individuen in totaal drankgebruik. De vraag kan worden gesteld of zulke verschillen tussen drinkers in alle drinksituaties blijken dan wel in sommige situaties meer dan in anderen tot uiting komen. In deze paragraaf wordt onderzocht in hoeverre zware drinkers zich in drinksituaties anders gedragen dan lichte drinkers en in hoeverre mogelijke verschillen tussern drinkers variëren met de kans op drinkgedrag in drinksituaties.

\subsubsection{De hypothesen}

Twee concurrerende hypothesen kunnen worden geformuleerd.

De eerste hypothese stelt:

Verschillen in zwaarte van drankgebraik zijn uitsluitend kwanitatief van aard.

Deze hypothese voorspelt dat verschillen tussen categorieën drinkers gelijk gespreid zijn over alle drinksituaties. 
De concurrerende hypothese stelt:

Verschillen in zwaarte van drankgebruik zijn kwalitatief wan aard.

Deze hypothese stelt dat verschillen tussen categorieen drinkers binnen bepalde situaties meer tot uitdrukking komen dan in andere.

\subsubsection{Methoden}

De zwaarte van het individuele drinkgedrag kan op werschillende manieren worden benadend. Traditioneel wordt uitgegaan wan de drinkfrequentie en de kwantiteit per keer (Cahalan at al. 1969 e.v.a.). Hier is de frequentie als indicator voor de zwarte van thet drinkgedrag gebruikt. Aan deze keuze lagen zowel praktische als theoretische overwegingen ten grondslag. Deze overwegingen worden uiteengezet in Bijlage 3.2. Er is niet zoals gebruikelijk uitgegan van de gemiddelde frequentie over een langere periode (meestal het laatste $1 / 2$ jaar), maar var de werkelijke frequentie tijdens de dagboekweek. De frequentie is geoperationaliseerd als he: totaal aantal gerapporteerde drinkgelegenheden tijdens de dagboekweek. Bij de mannen die tijdens de dagboek week clronken varieert dit totaal wan 1 tot 29 drinkgelegenheden. Ean wantal van 29 gelegenheden per week komt neer op gemiddeld vier drinkgelegenheden per dag. Bij de vrouwelijke drinkers var leert de drinkfrequentie wan 1 tot 17 drinkgelegenheden.

De drinkers zijn werdeeld in drie categorieen. De categorieën zijn zo gedefinieerd dat ze elk ongeveer evenveel drinkers bevatten.

In tabel 3.5. 1. zijn de verschillende categorieen en daarbij horende watrden woor drünkfrequentie weergegeven:

Tabell 3.5.1

Indeling van drinkers naar drinkfrequentie tijdens de dagboekweek.

\begin{tabular}{lcccc} 
Categorie & \multicolumn{2}{c}{ Mannen } & \multicolumn{2}{c}{ Vrouwen } \\
Drinkers & Frequentie & $\mathrm{N}$ & Frequentie & $\mathrm{N}$ \\
\hline Lichte drinkers & $1-4$ & 128 & $1-2$ & 90 \\
Matige drinkers & $5-9$ & 142 & $3-6$ & 92 \\
Zware drinkers & $10+$ & 125 & $7+$ & 93 \\
Niet gedronken & 0 & 98 & 0 & 148 \\
\hline
\end{tabular}

De definitie van een categorie drinkers als "zwaar" of "matig" is dus relatief ten opzichte van de andere drinkers in deze studie. Ze is niet bedoeld om an te geven hoe bepualde drinkers zouden moeten worden benoemd, noch is ze bedoeld als een oordeel over een totalal acceptabel drankgebruik. 
Ter toetsing van de bovern geformuleerde hypothesen is het totale drankgebruik verdeeld in het drankgebruik binnen vier categorieèn van drinksituaties. Deze categorieën wan situaties zijn :

1) De categorie van situaties waarin het gebruikelijker is on te drinken dan om niet te drinken. In concreto de groep van drinksituaties waarin de kans op drinkgedrag groter dan .50 is. Deze zullen de natte siluaties worden genoend.

2) De categorie van drinksituaties waarin het minder gebruikelijk is om te drinker maar wasarin de kans op drinkgedrag toch nog redelijk groot is $(.20<\mathrm{p}<.50)$. Dergelijke situaties worden medium situaties genoemd.

3) De categorie van drinksituaties waarin een van de vijf deelnemers of minder alcohol gebruikt, maar waarin drinken kennelijk geen uitzonderlijk gedrag is $(p \leq 20)$. Deze situaties worden droge situaties genoemd.

4) De categorie van drinksituaties die als 'abnormale' omstandigheden voor drinkgedrag gedefinieerd zijn.

Dalar de drinksituaties voor mannen en vrouwen afzonderlijk zijn gedefinieerd, verschillen de situaties die tot elk van bovenstaande categorieën behoren voor mannen en vrouwen. In tabel 3.5.2. is het totale drankgebruik per categorie van situaties, uitgesplitst naar drinkfrequentie voor mannen en voor vrouwen, weergegeven.

Tabel 3.5.2

De totale consumptie (in drinkkwartieren) per categorie van drinkers naar type drinksituatie en geslacht.

Type drinksituatie

Droog Medium Nat Abnormaal totaal

\section{Mannen}

lichte drinkers

matige drinkers

zware drinkers

65

291

927

Totaal mannen

1283

2887

2024

346

642

1036

76

262

583

921

7115

rrouwen

lichte drinkers

matige drinkers

zware drinkers

35

194

596

89

358

567

825

1014

Total vrouwen

220

41

67

112

52

217

719

1613

Ter toetsing van bovenstaande hypothesen is zowel de deelname aan drinksituaties als het gedrag binnen die situaties van de verschillende categorieën drinkers vergeleken. Daarbij zijn de volgende variabelen gebruikt: het aantal drinkers per categorie van drinksituaties, de drinkfrequentie van de drinkers binnen een categorie van drinksituaties, de kwantiteit per drinkgelegenheid van de drinkers binnen een categorie van drinksituaties en tenslotte het 
gemiddelde aandeel van het drankgebruik binnen een bepaalde categorie drinksituaties in bet totalle drankgebruik (per drinker).

De kwantiteit per drinkgelegenheid is per drinker berekend als het quotient van de totale consumptie in de betreffende drinksituaties (uitgedrukt in drinkkwartieren) en de frequentie. Een drinkkwartier staat ongeveer gelijk aan een glas alcoholhoudende drank. De gemiddelde kwantiteit per drinkgelegenheid varieert van $\mathbb{1}$ tot 10,25 bij de mannen en van 1 tot 10,0 bij de vrouwen. Het aandeel van de consumptie in een categorie van drinksituaties in de totale consumptie is eveneens per drinker berekend en wel als de consumptie in drinkkwartieren in de betreffende categorie gedeeld door de totale consumptie.

Op grond van de eerste hypothese mag worden verwacht dat het aandeel in het totale drankgebruik van het alcoholgebruik in elk der categorieèn van drinksituaties bij zware, matige en lichte drinkers even groot zal zijn. In elke categorie drinksituaties zal het aantal drinkende zware drinkers groter zijn dan het atantal lichte drinkers. Het verschil zal echter in alle categorieën van situaties gelijk zijn. Indien verschillen tussen de categorieën drinkers uitsluitend kwantitatief van aard zijn zal de kwantiteit per drinkgelegenheid binnen een categorie van situaties voor de zware drinkers groter zijn dan voor de lichte drinkers. Dit zal in alle drinksituaties in gelijke mate tot uiting komen. Tenslotte zal de drinkfrequentie binnen een groep van situaties variëren met de zwaarte van het drankgebruik. Zware drinkers drinken (per definitie) vaker dan lichte drinkers. Volgens de kwantiteitshypothese zal deze variatie binnen alle groepen van drinksituaties gelijk zijn.

\subsubsection{Resultaten}

Voor mannen en vrouwen afzonderlijk is in tabellen 3.5 .3 en 3.5 .4 voor lichte, matige en zware drinkers voor respectievelijk de droge, de medium, de natte en de abnormale drinksituaties het aantal drinkende deelnemers, hun gemiddelde scores voor kwantiteit per drinkgelegenheid en frequentie en het aandeel van die categorie van drinksituaties in het totale drankgebruik, weergegeven. De resultaten wan de analyses binnen de mannelijke en de vrouwelijke populatie zullen achtereenvolgens worden besproken.

\section{De mannen}

Van de mannen dronken er tijdens de dagboekweek 395 tenminste één alcoholische consumptie. Van de drinkers realiseerde $57 \%$ een of meer "abnormale drinkgelegenheden'. Eenzelfde percentage realiseerde tenminste een drinkgelegenheid binnen de droge situaties terwijl in de medium situaties $85 \%$ en in de natte situaties $61 \%$ van de drinkers een of meer drinkgelegenheden realiseerde. In alle typen situaties is het percentage zware drinkers dat drinkgelegenheden realiseerde hoger dan het percentage lichte of matige drinkers. De verschillen tussen de categorieën drinkers nemen af met de natheid van de drinksituaties. Het aandeel van de alcohol gedronken in 'abnormale drinkgelegenheden' in de totale consumptie was in alle categorieën drinkers gelijk. Hetzelfde geldt voor het aandeel in de totale consumptie van de consumptie binnen medium situaties. Het aandeel in de totale consumptie van de consumptie binnen natte situaties neemt af met de drinkfrequentie terwijl dat van de consumptie in droge situaties met de drinkfrequentie toeneemt. De categorieën drinkers zijan verdeeld op basis van totale drinkfrequentie. In alle situaties behalve de natte, varieert de frequentie significant met deze totale drinkfrequentie. Ook het gemiddeld alantal drinkgelegenheden gerealiseerd in natte situaties, is binnen de categorie zware drinkers het hoogst. Het verschill met de lichte en medium drinkers is echter niet significant. De kwantiteit 
per keer binnen de verschillende typen drinksituaties varieert in geen enkel geval significant met de totale drinkfrequentie. Ook deze is echter binnen de categorie zware drinkers steeds het hoogst.

Tabel 3.5.3

Kengetallen varn de categorieën drinkers per type drinksituaties, mannen.

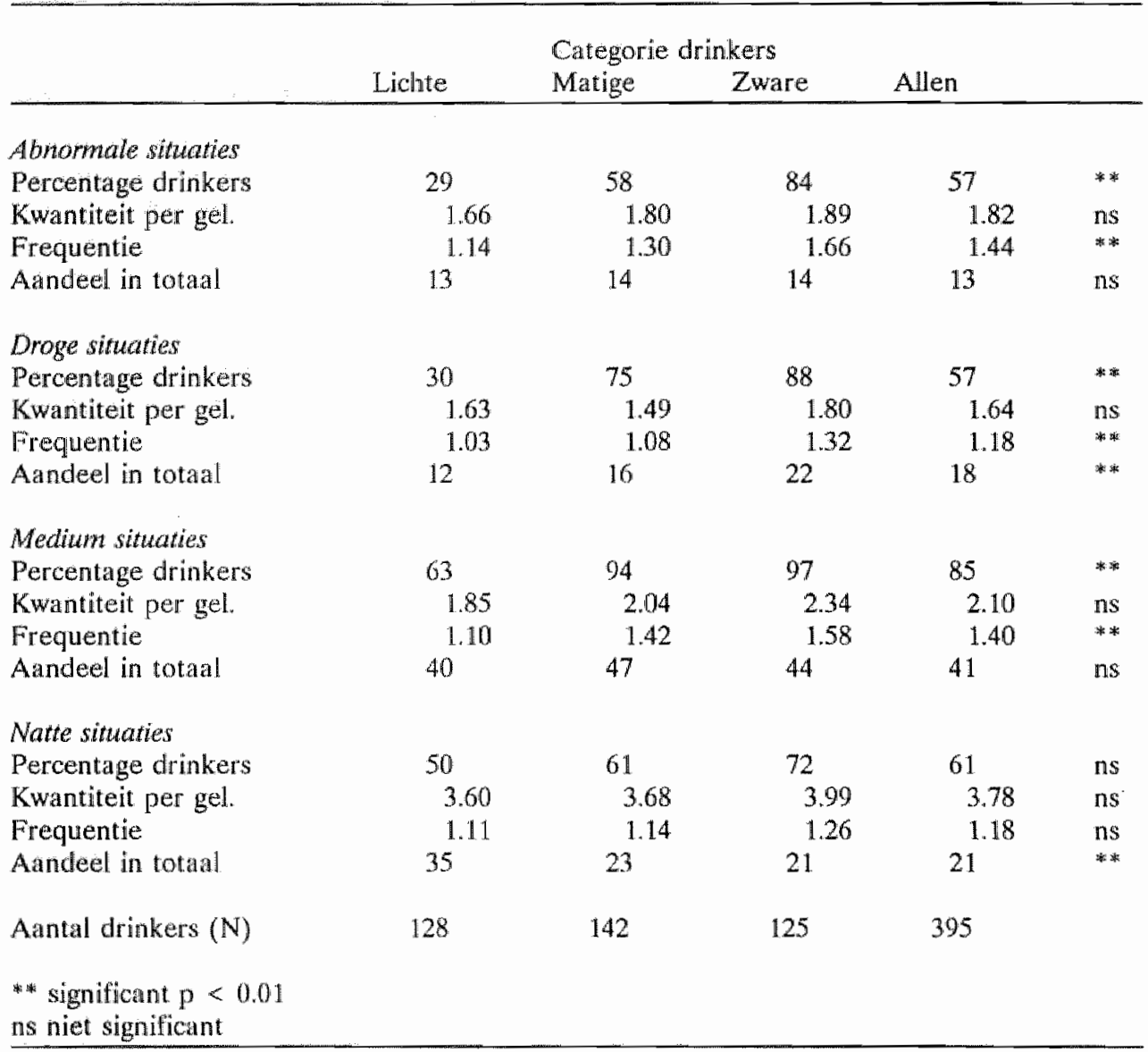

\section{De vrouwen}

De patronen in scores in de vrouwelijke populatie zijn in grote lijnen vergelijkbaar met die gevonden in de mannelijke populatie. Van de vrowwelijke drinkers $(n=275)$ realiseerde $56 \%$ een of meer "abnormale" drinkgelegenheden. In droge en medium situaties werden respectievelijk door $68 \%$ en $77 \%$ van de drinkende vrouwen drinkgelegenheden gerealiseerd. Bij de vrouwen waren er slechts twee drinksituaties watin de kans op drinkgedrag .50 of hoger was. Het aantal vrouwen dat in natte situaties drinkgelegenheden realiseerde was dan ook 
gering, $(17 \%)$. Er waren relatief meer zware dan lichte drinkers die binnen natte drinksituaties

Tabel 3.5.4

Kengetallen van de categorieen drinkers per type drinksituaties, vrouwen. Categorie drinkers Lichte Matige Zware Allen

Abnormale situaties

Percentage drinkers

Kwantiteit per gel.

Frequentie

Aandeel in totaal

Droge situaties

Percentage drinkers

Kwantiteit per gel.

Frequentie

Aandeel in totaal

\section{Medium situaties}

Percentage drinkers

Kwantiteit per gel.

Frequentie

Aandeel in totaal

\section{Natte situaties}

Percentage drinkers

Kwantiteit per gel.

Frequentie

Aandeel in totaal

Totaal

Aantal drinkers (N)

** significant $p<0.01$

ns niet significant

$\begin{array}{cc}36 & 48 \\ 1.44 & 1.56 \\ 1.13 & 1.48 \\ 28 & 15\end{array}$

$\begin{array}{ll}29 & 77 \\ 1.25 & 1.38 \\ 1.00 & 1.19 \\ 21 & 34\end{array}$

$\begin{array}{cc}50 & 86 \\ 1.69 & 1.99 \\ 1.07 & 1.19 \\ 42 & 45\end{array}$

10

3.81

1.00

8

90

92
3.14

1.06

7
89

1.41

3.03

21

98
1.41
1.34
38

95

1.85

1.46

35

23

3.17

1.21

5

93

275

drinkgelegenheden realiseerden ( $23 \%$ versus $10 \%)$. Door de kleine aantallen is dit verschil niet significant. Ook in de 'abnormale', de droge en de medium situaties is het aantal zware drinkers relatief het hoogst. De verschillen tussen zware, matige en lichte drinkers zijn ook bij de vrouwen het grootst in de 'abnormale' en de droge situaties.

Ook het aandeel in de totale consumptie van de consumptie in natte situaties varieert niet significant met de drinkfrequentie. Het neemt af met de zwaarte van het drankgebruik. Het aandeel in het totaal van de consumptie in 'abnormale' situaties is het hoogst bij de lichte drinkers. Het aandeel in het totaal van de consumptie in droge situaties is daarentegen het hoogst binnen de categorie zware drinkers. 
De gemiddelde frequentie binnen de verschillende typen drinksituaties, met uitzondering van de natte situaties, varieert significant met de zwaarte van het drankgebruik. Ze is het hoogst bimnen de categorie zware drinkers. De kwantiteit per keer varieert in geen der typen drinksituaties significant met de zwarte van het drankgebruik. Opvallend is dat de kwantiteit per keer binnen natte situaties bij de lichte drinkers hoger is dan bij de matige en zware drinkers.

\subsection{Conclusies en discussie}

In dit hoofdstuk is het drinkgedrag in Nederland beschreven en is nagegaan of er naar gelang consumptieniveau verschillen zijn in de verdeling van de consumptie over de te onderscheiden drinksituaties en/of de consumptie in die situaties.

In hoofdstuk 1 is drinkgedrag beschreven als een handeling. Er is gesteld dat onder andere temporele aspecten van situaties en de primaire activiteit bepalend zijn voor de beoordeling van de mate van gepastheid van drinkgedrag in die situaties. Verder is gesteld dat alleen dat drinkgedrag dat met een zekere regelmaat in het dagelijks leven voorkomt als een sociale gewoonte mag worden beschouwd. Aangenomen is dat de beoordeling van de gepastheid van drinkgedrag als sociale gewoonte samenhangt met de mate waarin drinkgedrag zich in een gegeven situatie voordoet. De sociale drinkgewoonten in Nederland zijn beschreven aan de hand van de kenmerken van drinksituaties èn de kans op drinkgedrag in die situaties. Drinksituaties zijn omstandigheden waarbinnen alcoholgebruik op grond van frequentie van voorkomen als 'normaal' gedrag mag worden beschouwd.

Uit de vergelijking van kenmerken van drinksituaties met resultaten van eerder onderzoek naar sociale drinkgewoonten in Nederland (Gadourek, 1958; Sijlbing, 1978; Schippers, 1981; Knibbe, 1984) kunnen geen veranderingen in deze sociale drinkgewoonten worden geconstateerd. De verschillen in gehanteerde onderzoekmethoden zijn te groot om specifieke conclusies ten aanzien van eventuele veranderingen te trekken. In Nederland bestaat nog steeds een grotere voorkeur om te drinken op weekend-dagen dan op weekdagen en voor avonden dan voor ochtenden of middlagen. 's Ochtends drinken kan alleen op zondag als 'normaal" gedrag worden beschouwd. De grotere voorkeur om te drinken in het weekend en de avonduren komt zeer uitdrukkelijk tot uiting in de verdeling over de gehele week van het aantal drinkers per uur. 's Avonds zijn er hogere pieken dan 's middags en de pieken in het aantal drinkers per uur zijn op weekend-dagen hoger dan op weekdagen. De voorkeur voor het weekend en de avond blijkt ook uit het relatief grotere aantal verschillende activiteiten dat op die tijden drinksituaties kenmerkt.

De grotere aantallen activiteiten kenmerkend voor drinksituaties op weekend-dagen en de, vergeleken met weekdlagen, hogere kans op drinkgedrag in die situaties kunnen als aanwijzingen voor weekend-drinken worden betiteld. Opmerkelijk is dat de zondagavond, in tegenstelling tot de vrijdagrovond, zich wat betreft de kans op drinkgedrag binnen drinksituaties niet onderscheid van de avonden van weekdagen. Dit laatste komt overeen met gegevens over alcoholgebruik en tijd uit respectievelijk een Scandinavische (Simpura, 1987) en een Amerikaanse studie (Arfken, 1988). Zondagavond behoort, alls omstandigheid voor drinkgedrag niet tot het weekend.

Het ligt voor de hand om te veronderstellen dat temporele variaties in het drinkgedrag worden gedetermineerd door temporele variaties in tijdbesteding. Het patroon in drinkgedrag volgt dat van de deelname aan vrije-tijd activiteiten (Knulst en Schoonderwoerd, 1983). Echter, ook de kans op drinkgedrag varieert op dezelfde wijze met de dag van de week en de tijd van de dag. 
De kans op drinkgedrag is berekend voor de deelnemers aan drinksituaties en is dus niet afhankelijk van de tijdbesteding. Het is zeer duidelijk dat temporele kenmerken van situaties mede bepalend zijn voor de beoordeling van de gepastheid van drinkgedrag in die situaties. Ook activiteiten hangen samen met de kans op drinkgedrag in drinksituaties. Activiteiten die drinksituaties kenmerken zijn ondermeer bezoek aan openbare drinkgelegenheden (café, kantine), sociale contacten (met huisgenoten, vrienden, kennissen of familie) en passieve ontspanning (televisie kijken, lezen of relaxen). Maar ook hobby's, karweitjes, eten, werk en zelfs slaap en persoonlijke behoeften zijn categorieën van activiteiten die drinksituaties kenmerken. Het meeste drinkgedrag vindt plaats in de huiselijke sfeer. De activiteit waarbij absoluut gezien het meest wordt gedronken is televisie-kijken. Drinksituaties waarin de kans op drinkgedrag het hoogst is worden gekenmerkt door de activiteiten café-bezoek en visite.

Drinksituaties zijn gedefinieerd op grond van de kenmerken van drinkgelegenheden. Drinkgelegenheden zijn daadwerkelijk gerealiseerde drinkgedrag. Er is een aantal empirische criteria gehanteerd ter bepaling van de 'normaliteit'van drinkgelegenheden. Dit waren minimale criteria. Een drinkgelegenheid is uitzonderlijk beschouwd wanneer minder dan één procent van de populatie zo'n drinkgelegenheid realiseert. Vanwege de gehanteerde definitie is de mate waarin een gelegenheid zich in het dagelijks leven voordoet een factor die mede bepaalt of een gelegenheid als 'normaal' kàn worden gedefinieerd. Gelegenheden die veel voorkomen, waaraan dus veel mensen deelnemen, zullen eerder als normale drinkgelegenheden gedefinieerd worden. dan gelegenheden waaraan minder mensen deelnemen. Bij een gelijke kans op drinkgedrag zal. de grens om een gelegenheid als 'normaal' te definiëren namelijk eerder worden overschreden. Door deze procedure zijn enkele gelegenheden gekenmerkt door weel voorkomende activiteiten waarbij niet of nauwelijks wordt gedronken toch als gedrag in drinksituaties gedefinieerd. Dit zijn de situaties gekenmerkt door de activiteiten slaap en persoonlijke verzorging. In deze situaties is de kans op drinkgedrag dan ook laag $(p=.02-.03)$. Ze mogen zeker niet als realisaties van de sociale drinkgewoonten in Nederland worden beschouwd.

De kenmerken van 'normale" drinkgelegenheden zijn gebruikt om drinksituaties te definiëren. Twee drinkgelegenheden zijn als plaatsvindend in eenzelfde idealal-typische drinksituatie beschouwd wanneer ze niet verschillen in definiërendle activiteit, periode van de dag èn kans op drinkgedrag.

Er is veronderstelld dat verschillen in de kans op drinkgedrag verschillen in de perceptie van de gepastheid van drinkgedrag in situaties reflecteren. Hoe groot verschillen in kans moeten zijn om verschillen in perceptie te mogen veronderstellen kan op theoretische gronden niet worden. bepaald. De definitie van drinksituaties die hier is gehanteerd resulteert in een groot aantal drinksituaties. Vergelijkbare drinksituaties zoals bijwoorbeeld visite aan familie op de middagen van weekdagen of visite aan vrienden of kennissen op dezelfde tijdstippen verschillen niet of nauwelijks in de kans op drinkgedrag (beiden $p=17$ ). Er zijn ook situaties die worden gekenmerkt door eenzelfde periode en activiteit waartussen de (significante) verschillen in kans zeer klein zijn (bijv. massa-media op maandag tot en met zaterdag middag en massa-media op zondagmiddag). Bij beschouwing achteraf zou kunnen worden geconcludeerd dat dergelijke situaties wellicht tot dezelfde ideaal-typische drinksituatie moeten worden gerekend.

Zowel ten aanzien van de criteria voor normaliteit als ten aanzien van de criteria om gelegenheden tot dezelfde situatie te rekenen is hier het uitgangspunt gehanteerd dat de mogelijke vertekening in resultaten kleiner en het informatiegehalte groter zal zijn wanneer er 'ten onrechte' situaties als sociale drinkgewoonten worden aangemerkt of van elkaar worden onderscheiden dan wanneer er 'ten onrechte" situaties worden uitgesloten cq. als gelijksoortig worden beschouwd. 
Her aantal drinksituaties is binnen de mannelijke populatie groter dan in de vrouwelijke populatie. In vergelijkbare situaties is cle kans op drinkgedrag bij mannen ook hoger dan bij vrouwen. Enerzijds kunnen deze bevindingen geinterpreteerd worden als algemene sexegerelateerde verschillen in de perceptie van de gepastheid van drinkgedrag. Anderzijds kunnen $z e$ woor een deel verklaard worden uit het hogere aantal vrouwen dat tijdens de dagboekweek niet heeft gedronken. Omdat zowel 'normaliteit' van drinkgelegenheden als kans op drinkgedrag in drinksituaties zijn berekend voor de gehele populatie cq. alle deelnemers aan situaties zal een hoger aantal niet-drinkers resulteren in minder 'normale' drinkgelegenheden en lagere kansen op drinkgedrag in drinksituaties. Dit is het gevolg van de gehanteerde definities mar is wel in overeenstemming met de aanname betreffende de gepastheid van sociale gewoonten. Ook verschillen in het aantal mensen dat niet drinkt reflecteren verschillen in de beoordeling van de gepastheid van drinkgedrag.

De veronderstellingen over de wijze waarop regels en verwachtingen waargenomen worden en hoe deze perceptie tot uiting komt in het objectief waarneembare gedrag zijn weliswaar aannemelijk maar kunnen alleen worden getoetst door ook daadwerkelijk de perceptie van situaties door sociale actoren te onderzoeken. De situaties zoals hier gedefinieerd zouden aan sociale actoren ter beoordeling en rangschikking naar de mate waarin drinkgedrag gepast wordt geacht kunnen worden voorgelegd. Verwacht wordt dat resultaten van een dergelijk onderzoek de hier gepresenteerde resultaten zullen bevestigen.

Op basis van de kans op drinkgedrag zijn de drinksituaties verdeeld in drie categorieën: droge, medium en natte situaties. Een vierde categorie wordt gevormd door alle drinkgedrag dat niet in drinksituaties is gerealiseerd, het 'abnormale' drinkgedrag.

Betreffende de aard van verschillen in drinkgedrag tussen drinkers zijn twee hypothesen geformuleerd, de kwantiteitshypothese en de kwaliteitshypothese.

Deze hypothesen werden onderzocht door binnen elk van de vier categorieën van drinksituaties het drinkgedrag van, op basis van drinkfrequentie gedefinieerde, zware, matige en lichte drinkers te vergelijken.

Verschillen tussen zware, matige en lichte drinkers blijken zowel kwantitatief als kwalitatief van aard te zijn.

Kwantitatieve verschillen blijken uit het resultaat dat zware drinkers in dezelfde drinksituaties vaker en meer drinken dan lichte drinkers. Kwalitatieve verschillen blijken hieruit dat zware drinkers eveneens in meer situaties drinken. De verschillen in drinkgedrag tussen lichte en zware drinkers zijn het meest uitgesproken binnen situaties waarin de kans op drinkgedrag relatief laag is. Dit suggereert dat intensivering van het drinkgedrag op individueel niveau, het resultat is van een uitbreiding van het aantal verschillende situaties waarin een drinker alcoholgebruik als passend gedrag beschouwt. Naast de "natte' situaties voegen zware drinkers 'minder gebruikelijke' drinksituaties toe aan hun repertoire van mogelijke drinksituaties.

Indien deze veronderstelling juist zou zijn biedt ze mogelijkheden om screeningsinstrumenten voor zwaar drinken (probleemdrinken) te antwikkelen warin geen bedreigende vragen voorkomen. Door mensen te laten aangeven of ze 'weleens' drinken in een aantal gespecificeerde drinksituaties kunnen degenen die in de minder gebruikelijke situaties drinken als mogelijke risicogroep worden opgespoord.

Uit de beschrijving van de drinksituaties en de verschillen tussen lichte, matige en zware drinkers kan worden afgeleid welke plaats alcoholgebruik in het dagelijks leven heeft en kunnen aanwijzingen omtrent het proces van intensivering van drinkgedrag worden afgeleid. 
Enerzijds is drinkgedrag duidelijk verbonden met bepaalde tijdstippen en activiteiten. Anderzijds mag worden geconcludeerd dat drinkgedrag in Nederland alomtegenwoordig is. Er zing geen activiteiten warbij helemaal niet gedronken wordt en in een doorsnee week drinkt meer dan de helft van alle drinkers ( 380 van de 670), tenminste én keer in een drinkgelegenthid warin het ongebruikelijk is om te drinken. Hoewel duidelijk is in welke situaties drinkgedrag "normaal" is, blijkt de "abnormaliteit" van drinkgedrag buiten drinksituaties geen absolute barriare on drinken te voorkomen. Drinken in droge of abnormale situaties komt weliswar meer voor onder zware drinkers, maar blijkt binnen alle categorieën drinkers geen ongewone zaak te zijn. Samen met het gegeven dat het gedrag in drinksituaties, de kwantiteit per keer, niet duidelijk verschilt tussen de categorieën drinkers betekent dit dat intensivering van drinkgedrag vrijwel onopgemerkt kan plaatsvinden. 


\section{Hoofdstuk 4}

Rollen en drinkgedrag:

vragen, hypothesen en methoden

\subsection{Inleiding}

In het voorafgaande hoofdstuk is beschreven binnen welke situaties drankgebruik als een geaccepteerde vorm van gedrag mag worden beschouwd. Deze situaties zijn drinksituaties genoemd in de betekenis van situaties waarin er social gezien geen barrières ten aanzien van drankgebruik bestaan. De analyses in dit hoofdstuk zijn beperkt tot het sociaal geaccepteerde drankgebruik. Dat wil zeggen dat het drinkgedrag onder 'niet-normale' omstandigheden buiten beschouwing wordt gelaten.

In het vorige hoofdstuk was de situatie analyse-eenheid, in dit hoofdstuk is de respondent analyse-eenheid. In de totstandkoming van drinkgedrag kunnen twee fases, namelijk de gelegenheid om te drinken en de realisatie van drinkgedrag, worden onderscheiden. Deze fases zullen in paragraaf 4.1.1 nader worden beschreven. Er wordt verondersteld dat positie- en statusrollen het drinkgedrag van sociale actoren kunnen beïnvloeden. Op basis van literatuur over alcoholonderzoek en tijdbesteding zal worden aangegeven hoe rollen in de verschillende fases van invloed kunnen zijn. Vragen en veronderstellingen worden geformuleerd (paragrataf 4.2) en de wijze waarop deze zijn onderzocht wordt beschreven (paragraaf 4.3). In hoofdstukken 5 en 6 tenslotte, worden de resultaten van de analyses gepresenteerd. 


\subsubsection{Een algemeen model}

Verklaringen van werschillen in drinkgedrag tussen sociale actoren kunnen zich op een of op beide fases in de totstandkoming van drinkgedrag richten. Binnen de eerste fase worden verschillen in consumptie verklaard uit verschillen in de gelegenheid tot drankgebruik (structurele verklaringen). Centraal in deze structurele verklaringen staat de relatie tussen gelegenheid en consumptie. Binnen de tweede fase worden verschillen in consumptie verklaard uit verschillen in de mate warin de gelegenheid om te drinken dadwerkelijk wordt benut (realisatie verklaringen), de intensiteit van het drankgebruik. Deze twee type verklaringen sluiten elkaar niet uit, ze wullen elkar eerder aan.

De centrale variabelen in de beschrijving van het drinkgedrag zijn de gelegenheï tot dramkgebruik en de daadwerkelike consumptie. In een model ter verklaring van verschillen tussen personen in alcoholconsumptie in drinksituaties kunnen verschillende categorieen factoren worden onderscheiden:

1. Factoren die samenhangen mett de gelegenheid tot drankgebruik.

2. Factoren die de relatie tussen de gelegenheid en de consumptie beïnvloeden.

In dit model is de gelegenheid om te drinken een centrale variabele. Deze gellegenheid wordt geoperationaliseerd (zie ook puragraa 4.3.2) als de tijd die in drinksituaties wordt doorgebracht.

In dit hoofdstuk worden de relaties tussen de positie- en statusrollen die mensen bekledien en de gelegenheid om te drinken alsmede de relaties tussen rollen, gelegenheid en daadwerkelijke consumptie onderzocht. Er zijn voldoende redenen om samenhangen tussen rollen en de gelegenheid tot drankgebruik te mogen veronderstellen.

Hoeveel tijd men doorbrengt in een bepaalde situatie word mede bepaald door de positierollen clie men vervult. Positierollen stellen mogelijk grenzen aan de mate waarin en de tijden waarop men in drinksituaties kan verkeren. In hoofdstuk 3 bleek namelijk dat bijna alle drinksituaties vrije-tijdssituaties zijn. Uitzonderingen hierop vormen de situaties gekenmerkt door de activiteiten Eten, Slapen, Persoonlijke verzorging, Werk en Huishoudelijk Werk. Al deze situaties worden gekenmerkt door een erg lage kans op drankgebruik. Bij de activiteiten die deze situaties kenmerken wordt door mannen ongeveer $11 \%$ en door vrouwen $15 \%$ wan het toliale daakgebruik gerealiseerd. Positierollen brengen per definitie verplichtingen met zich mee. Het vervullen van deze verplichtingen kost tijd en is meestal ook nog eens gebonden aan bepande uren van de dag. Het duidelijkste voorbeeld hiervan wordt gevormd door de positierollen in verband met betaild werk. Niet alleen het aantal uren per week ligt wast, ook de tijden waarop de verplichtingen verbonden aan de rol als werkende kunnen worden vervuld zijn gefixeend. Daarmee bepaalt deze rol de structuur wan het dagelijks leven. Maar ook minder stringente positierollen als die van Scholier of Student dan wel als Huisvrouw geven een bepalde structuur zan het dagelijks leven. Ze eisen een tijdsinvestering in bepaalde vastgestelde activiteiten en zijn vaak gebonden aan vaste tijden. Daarom kan worden gesteld dat positierollen het dagelijks leven structureren. Aldus bepalen positierollen de mogelijke expositie aan drinksituaties. Alle tijd die niet in het kader van positierollen wordt besteed kàn in theorie in drinksituaties worden doorgebracht.

Binnen de grenzen vastgesteld door positierollen, zullen er nog variaties zijn in de tijd die daadwerkelijk in drinksituaties wordt doorgebracht. Dit zijn dan variaties in de vrije- 
tijdsbesteding. Er mag worden aangenomen dat de in statusrollen besloten algemene gedragsorientatie van invloed is op de mate waarin men zijn vrije tijd besteedt in drinksituaties. Volgens bovenstaande redeneringen zal een gebrek aan structurerende positierollen leiden tot een hogere alcoholconsumptie doordat er een grotere gelegenheid tot drankgebruik ontstaat. In navolging van Philipsen (1976) geeft Knibbe (1984) aan waarom bij een gebrek aan structurerende positierollen ook de kans op realisatie van drinkgedrag groter is. De verklaring voor verschillen in realisatie die Knibbe geeft, is dat mensen met weinig structurerende positierollen mogelijk geneigd zijn on (onder andere) situatierollen waarin drank wordt gebruikt, te intensiveren om daarmee een tekort aan structuur in het dagelijks leven te compenseren (Knibbe, 1984).

Van statusrollen mag ook worden verwacht dat ze samenhangen met de mate waarin bij een gegeven gelegenheid daadwerkelijk wordt gedronken. Uit de resultaten van hoofdstuk 3 komt bijvoorbeeld al naar voren dat geslacht een belangrijke bepalende factor is voor de intensiteit waarmee van drinksituaties gebruik wordt gemaakt.

In de nu volgende paragraaf zal allereerst worden beschreven welke relaties tussen status- en positierollen en de gelegentheid tot en realisatie van drankgebruik op grond van de literatuur mogen worden verwacht. Er zal worden geëvalueerd in hoeverre er steun te vinden is voor het algemene model dat in deze inleiding is beschreven. Daarna wordt een aantal van de veronderstellingen die in dit model besloten liggen expliciet gemaakt. In paragraaf 4.3 wordt vervolgens beschreven hoe deze veronderstellingen zijn onderzocht.

\subsubsection{Rollen en drinkgedrag}

Verschillen in totale consumptie binnen het geheel van drinksituaties kunnen volledig worden verklaard door verschillen in de gelegenheid om te drinken èn verschillen in de mate waarin bij een bepaalde gelegenheid drinkgedrag wordt gerealiseerd. De gelegenheid tot drankgebruik is omschreven als de duur van het verkeren in drinksituaties. In de vorige paragraaf is een aantal factoren beschreven welke mogelijk met deze gelegenheid tot drankgebruik samenhangen. In deze paragraaf zullen factoren worden onderzocht die met de mate van realisatie van drankgebruik of de gelegenheid tot drankgebruik samenhangen. Hier zal worden uitgegaan van de positie- en statusrollen die mensen vervullen.

Statusrollen waarvan herhaaldelijk is aangetoond dat ze met alcoholconsumptie samenhangen zijn geslacht, leeftijd, sociale klasse, religie en etnische groepering (Knibbe, 1984, Middleton Fillmore, 1987). Statusrollen bieden een algemene gedragsorièntatie, ook ten aanzien van alcoholgebruik. Uit de resultaten van hoofdstuk 3 blijkt dat de statusrol geslacht sterk samenhangt met de mate waarin binnen drinksituaties drinkgedrag wordt gerealiseerd. Ook van andere statusrollen mag worden verwacht dat ze alcoholconsumptie beinvloeden via de mate waarin alcoholgebruik in drinksituaties wordt gerealiseerd.

Sijlbing (1978) noemt als structurele samenhangen tussen statusrollen en alcohol consumptie dat. mannen meer drinken dan vrouwen, dat de hogere klassen vaker maar matiger drinken dan de lagere klassen en dat protestanten minder drinken dan degenen zonder religie of roomskatholieken. De dagelijkse drinkers komen met name voor bij mensen van middelbare leeftijd terwijl het periodiek veel drinken onder de jongeren het meest voorkomt. Deze resultaten komen overeen met de relaties tussen deze rollen en alcoholgebruik die Gadourek (1963) constateerde en met die welke Knibbe (1984) rapporteert.

Met betrekking tot het ontbreken van structurerende positierollen veronderstelt Knibbe (Knibbe 
et al, 1987) dat dit niet alleen tot een grotere gelegenheid tot drankgebruik leidt maar ook to wen intensivering van sifuaties waarin alcohol wordt gebruikt. Knibbe loetst deze verondarstelling door het aantal zware drinkers binnen groepen met een verschillend aantal structurerende positierollen te vergelijken. Hij constateert dat een gebrek an structur samengaat met een relatief groot aantal zware drinkers, maar ook met een relatief groot aantal lichte drinkers.

De omstandigheden waarin het drankgebruik wordt gerealiseerd, worden door Knibbe niet onderzocht. Ook kan Knibbe niet anangeven of de hogere consumptie een gevolg is van een grotere gelegenheid tot drankgebruik of van een intensievere benutting van drinksituaties. In het algemeen wordt in alcoholonderzoek geen onderscheid gemaakt tussen de gelegenheid om te drinken en de mate waarin hiervan gebruik wordt gemaakt om drankgebruik te realiseren. Er wordt weliswaar onderzocht of het gebruik van alcoholhoudende cranken van verschillende groepen verschilt, de omstandigheden war rin dat gebruik plaatsvindt worden in zulk onderzoek echter niet of nauwelijks betrokken. Er kunnen dan ook meestal geen conclusies worden getrokken over de vraag in hoverne verschillen in drankgebruik voortkomen uit verschillen in de gelegenheid tot drankgebruik of uit verschillen in de realisatie van drankgebruik. Uit de alcoholliteratuur kan echter wel worden afgeleid welke relaties tussen realisatie en rollen zouden kunnen worden werwacht.

Een van de meest onderzochte relaties tussen alcoholgebruik en positierollen betreft die met werk of werkloosheid. Op grond van de verbanden tussen werkloosheid en psychisch welbevinden of Lichamelijke gezondheid (McKenna en McEwan, 1987; Haworth ancil Evans, 1987) worden over het algemeen verbanden tussen werkloosheid en drankgebruik verondersteld (Winton et al. 1986). Een algemene aanname is dat werklozen een hogere alcoholconsumptie zouden hebben dan werkenden,

Winton et al. (1987) presenteren een overzicht van verwachtingen over de relatie tussen werkloosheid en drankgebruik. Ze onderscheiden twee algemene hypothesen dis een hogere alcoholconsumptie van werklozen veronderstellen.

De eerste hypothese ('stress'-hypothese) stelt dat werklozen ten gevolge van de spanningen die met werkloosheid gepaard gaan tot een hoger drankgebruik zouden komen. De weede hypothese ('leisure-time' hypothese) stelt dat de wijze waarop werklozen hun tijd gebruiken tot een hogere consumptie kan leiden. Werklozen besteden meer tijd aan alle soorten activiteiten (behalve werk-gerelateerde) dus ook aan "recreational activithes'. Degenen met 'natte' hobby"s (darts, pool-biljart ed) zouden daarom extra risico lopen op verhoogd drankgebruik.

Hoewel deze hypothesen geformuleerd zijn met het oog op werkloosheid kunnen ze ook op positierollen in het algemeen van toepassing worden geacht.

De twee hypothesen komen sterk overeen met de twee fasen in de verklaring van verschillen in drankgebruik. De leisure-time' hypothesen betreffen de gelegenheid om te drinken, da 'stress' hypothesen de mate warin drankgebruik wordt gerealiseerd.

Winton et al. (1986) kunnen in de literatuur geen empirische steun voor deze hypothesen vinden. Zij wijten dit ondermeer aan de meestal gehanteerde onderzoeksmethoden (met name aan het gebrek aan longitudinaal onderzoek). Uiteindelijk concluderen zij dan ook dat 'there is no adequate evidence for either of these hypotheses:. Ook Crawford et al. (1987) conduderen. op grond wan een literatuuroverzicht met betrekking tot empirisch onderzoek naar verbanden tussen werkloosheid en alcoholgebruik dat er geen eenduidige relatie kan worden gevonden. Letterlijk, en ietwat cynisch, concluderen zij: "unemployment either affects alcohol-use or it does not'. Uit eigen onderzoek concluderen zij dat er weliswaar geen verschillen in totale consumptie 
zijn tussen werkenden en werklozen maar dat werklozen wel significant meer drinken tijdens hun zwaarste drinkdag, meer tijd besteden in drinkgelegenheden (zij blijven dus langer in de drinksituaties) en een hoger drinktempo (aantal glazen per uur) hebben wanneer ze drinken. Een van de conclusies die Crawford et al. (1987) trekken is dat de wijze waarop alcoholgebruik wordt gemeten van invloed kan zijn op de relaties die worden gevonden. Dit blijkt ook uit een onderzoek van van der Horst (1988). Hij constateert geen verschil in het percentage drinkers onder de werkenden en dat onder werklozen. Wèl is de gemiddelde consumptie per week van werkenden significant lager dam die van werklozen (13,4 glazen versus 18,4 glazen). In vergelijking met arbeidsongeschikten drinken werkenden gemiddeld niet meer. Het aantal drinkers is daarentegen wel hoger onder de werkenden dan onder de arbeidsongeschikten. Biovenstaande onderzoeken en de onderzoeken waarop deze hun vooronderstellingen baseren betreffen allen werkende en werkloze mannen.

De gepostuleerde (positieve) relaties van drankgebruik met werkloosheid gaan uit van een verlies van betekenisvolle bezigheden in het dagelijks leven bij het ontbreken van een betaalde baan. De structurerende rol van werkende ontbreekt. Er kan aangenomen worden dat zulke structurerende effecten niet exclusief voor de rol van werkende zijn. Het ontbreken van anclere structurerende, zingevende rollen zal vergelijkbare effecten hebben (Knibbe et al., 1987). Het ontbreken van de partnerrol of de rol van verzorger/opvoeder kan daarmee ook als een risicofactor voor alcoholgebruik worden gezien.

Ook bij vrouwen mogen relaties tussen de positierollen en drinkgedrag worden verondersteld. Terwijl in het algemeen wordt verondersteld dat werkloze mannen meer drinken dan werkende mannen wordt bij vrouwen soms van het tegenovergestelde uitgegaan. 'In entering the labour' market women acquire a greater economic independence and probably develop a different life style, with greater participation in public life compared to that of the traditional role of the housewife. This implies that women in employment should have a higher consumption of alcohol' (Shaw, 1980). Als indirect effect van hun positie zouden werkende vrouwen dus een grotere gelegenheid tot drankgebruik hebben dan vrouwen die niet werken en mede daardoor meer drinken. Ook vrouwen die in meer 'mannelijke' beroepen werkzaam zijn drinken meer, doordat ze een meer mannelijke gedragsoriëntatie ten aanzien van alcoholgebruik ontwikkelen (Crawford et al., 1987).

Een toegenomen gelegenheid tot drankgebruik is een van de redenen die Hammer en Vaglum (1989) noemen ter verklaring van de stijging in de gemiddelde alcoholconsumptie bij vrouwen. Een andere verklaring die zij vermelden gaat weer uit van de stress-hypothese (realisatie). Ten gevolge van conflicten tussen de rol van moeder en werkende zou 'stress' ontstaan en daarmee samenhangend een hoger drankgebruik. Een teveel aan structurerende rollen zou een risicofactor zijn. Echter ook een gebrek aan structurerende rollen wordt als mogelijke oorzaak wan stress in samenhang met drankgebruik bij vrouwen genoemd. Met name het ontbreken van de partnerrol (bijvoorbeeld door scheiding) of het wegvallen van de rol van verzorgster (het lege nest-syndroom) worden bij vrouwen als bronnen van spanningen waaruit drankgebruik voort zou vloeien genoemd. Empirische bewijzen voor deze veronderstellingen kunnen Fammer et al. niet winden. Uit eigen onderzoek concluderen zij dat werschillen in drankgebruik tussen werkende en niet-werkende vrouwen verklaard kunnen worden door de factoren leeftijd, inkomen en urbanisatiegraad (bevolkingsdichtheid). Zij concluderen verder dat, ceteris paribus, werkende wrouwen met kleine kinderen minder drinken dan die zonder kleine kinderen. Zij suggereren dat dit een gevolg zou zijn van een geringere mogelijkheid, minder gelegenheden, tot drankgebruik van vrouwen die voor jonge kinderen moeten zorgen. 
Status en positie zijn niet onathankelijk wan elkar. Met name leeftijd bangt sterk samen met de posities die mensen (kunnen) bekleden. In een aantal studies naar drankgebruik is duidelijk met de verwevenheid van status en positie rekening gehouden. Ekerdt et al. (1989) vergeliken in een panel-studie twee groepen mannen boven 55 jaar. De gemiddelde leeftijd van de groepen is gelijk. Bij deze groepen zijn twee metingen verncht met wwee jaar tussentijd. De ene groep is na de eerste meting gepersioneerd en de andere groep niet. Ekerdt et al. weronderstellen dat het wegvallen wan werk ten gevolge van pensionering stress-inducerend kan zijn en daarmee drankgebruik kan doen toenemen. Zij geven verder aan dat een verhoogde consumptie na pensionering mogeligk wordt door een toename van wrije tijd en het grotendeels wegvallen van negatieve sociale gevolgen van zwaar drankgebruik (werkverzum e.d). Empirisch bewijs voor deze veronderstellingen vinden zij echter niet. Hoewel de variatie in scores tussen tijdstip 1 en tijdstip 2 bij de gepensioneerden iets groter is, is hun gemiddelde drankgebruik niet significant hoger of lager dan dat van hun werkende lexftijdsgenoten. Ten aanzien van alcoholgebruik constateert van der Horst (1988) dat bij controle voor leeftijd, werkenden niet verschillen van vervroegd gepensioneerden. Ook Glynn et al (1988) constateren geen verschillen in drankgebrtik tussen gepensioneerde en werkende mannen van gelijke leeftijd. Onder de ouderen is er schijnbaar geen invloed van niet (meer) werken (pensioen) op de alcoholconsumptie.

In een onderzoek bij jongeren van 23 jaar vindt Power (1989) een verschil in het percentage zware drinkers onder degenen die in de afgelopen 7 jaar langer dan 6 maanden werkloos geweest zijn en degenen voor wie dat niet het geval is geweest. Dit verschil is niet afhankelijk van de zwaarte van het drinkgedrag op jongere leeftijd (16 jaar). Werkloosheid zou in dit geval samenhangen met een hogere consumptie. Power concludeert echter eveneens dat; "it appears that employment experiences are less influential than formation of families in this age group (Power, 1989).

Uit bovenstaand literaturoverzicht kan worden geconcludeerd dat positie- en statusrollen factoren zijn die zowel met de gelegenheid tot drankgebruik als met de mate waran die gelegenheid daadwerkelijk wordt benut om te drinken kunnen samenhangen. In de alcoholliteratuur worden twee algemene hypothesen ter verklaring van verschillen in drankgebruik gerelateerd aan positierollen gehanteerd. Deze passen uitstekend binnen de twee fasen die in paragraaf 4.1. zijn gepresenteerd.

Een algemene hypothese stelt dat verschillen in gelegenheid tot drankgebruik een verklaring van verschillen in consumptie zouden kunnen zijn. Er is echter geen empirisch onderzoek warin de gelegenheid tot drankgebruik direct is gemeten. Resultaten van tijdbestedingsliteratuur zouden: inzicht kunnen verschaffen in de aannemelijkheid van de veronderstelling dat het ontbreken van structurerende positierollen kan leiden tot een grotere gelegenheid om te drinken. In paragraaf 4.1 .3 zullen resultaten van tijdbestedingsliteratuur worden onderzocht. Met het materiaal dat in dit onderzoek wordt gebruikt kan direct en objectief worden gemeten hoe groot de gelegenheid tot drankgebruik is. Relaties tussen gelegenheid en rollen (zowel status- als positierollen) kunnen datardoor worden vastgesteld.

De tweede algemene hypothese ter verklaring van verschillen in drankgebruik gaat uit wan het ontbreken wan structumr of zin in thet dagelijks leven als oorzaak van een verhoogde consumptie. Mede door stress of spanningen zou een intensiever drankgebruik tot stand komen. Een mogelijke reden waarom geen eenduidige resultaten omtrent deze hypothese worden gevonden zou kumen zijn gelegen in onduidelijkheid met betrekking tot de relatie tussen spanningen, stress en drankgebruik (Vollpicelli, 1987). Glynn et al. (1988) kunnen geen relatie tussen stress 
en drankgebruik vinden. Het verband tussen spanningen en drankgebruik lijkt meer gebaseerd te zijn op geloof dan op empirische feiten. Hoe dan ook, verschillen in drankgebruik ten gewolge van dit soort factoren zijn niet zozeer het gevolg wan verschillen in de gelegenheid om te drinken als wel van verschillen in de mate waarin van die gelegenheid gebruik wordt genaakt om drankgebruik te realiseren. Noch de betekenis wan drankgebruik noch stress of spanningen zijn factoren die in het hier te gebruiken materiaal zijn gemeten. Doordat de gelegenheid tot drankgebruik direct kan worden wastgesteld is het echter wel mogelijk om de mate waarin bij een bepaalde gelegenheid tot drankgebruik ook daadwerkelijk is gedronken, vast te stellen. Verklaringen voor mogelijk verschillen die in de realisatie van drankgebruik optreden kunnen alleen hypothetisch worden aangegeven. De verklaringen in de literatuur van verschillen in drankgebruik in relatie tot positierollen gaan voor een belangrijk deel over de rol van werkende of het ontbreken daarvan. Men kan zich afvragen of dit oorzaak of gevolg is van het feit dat de meeste onderzoeken onder mannen zijn uitgevoerd. Hoe dan ook, de gegevens met betrekking tot de rollen van partner of verzorger van jonge kinderen alsmede de effecten van positierollen bij vrouwen zijn veel minder vaak onderzocht.

\subsubsection{Tijdbestedingsonderzoek en de gelegenheid tot drankgebruik}

De weronderstelling die in deze paragraaf wordt onderzocht is of de gelegenheid tot drankgebruik inderclaad groter is bij een gebrek aan structurerende positierolJen. Daar er in de literatuur geen bronnen te vinden zijn waarin de gelegenheid tot drankgebruik direct is onderzocht worden indirecte, op tijdbestedingsonderzoek gebaseerde literatuurgegevens gebruikt. In het onderzoek 'Waar blijft de tijd' (Knulst en Schoonderwoerd, 1983) wordt de tijdbesteding van 'de Nederlander' uitgebreid beschreven. Knulst beschrijft de verschillen in tijdbesteding tussen werkende mannen en mannen zonder full-time baan. De mannen zonder betaald werk hebben per week gemiddeld $33 \%$ meer tijdl te besteden dan de werkende mannen. Deze extra tijd wordt niet evenredig gespreid over alle mogelijke activiteiten. Een meer dan evenredig deel wordt besteed aan Huishoudelijk werk en Massa-media, een ongeveer evenredig deel wordt besteed aan 'Sociale contacten en 'Overige wrije-tijdsbesteding', een minder dan evenredig deel wordt besteed aan 'Nachtrust, Maaltijden en Persoonlijke verzorging'. Aan alle categorieën van activiteiten (met uitzondering van Werk natuurlijk) wordt door mannen zonder full-time baan meer tijd besteed dan door mannen met full-time baan.

Deze verschillen in tijdsbesteding vallen grotendeels weg op weekend-dagen (wanneer ook de werkenden niet werken). Op weekend-dagen resteren verschillen tussen werkenden en niet werkenden in de tijdsbestedling aan 'Massa-media' en 'Overige vrije-tijdsbesteding'. Het alantal uren dat werkenden en werklozen alsmede gepensioneerden aan elk van de hoofdcategorieèn van tijdsbesteding spenderen is weergegeven in tabel 4.1.1.

Zoals hiervoor is aangetoond zijn Sociale contacten, Massa-media en Overige vrije-tijdsbesteding activiteiten die drinksituaties kunnen kenmerken. Uit deze globale gegevens kan worden afgeleid dat de gelegenheid tot drankgebruik bij mannen zonder werkkring inderdaad groter is dan bij mannen met werkkring. Werklozen besteden per week gemiddeld ruim 25 uur meer dan werkenden aan 
Tabel 4.1.1

Tijobesteding van werkende, werkloze en gepensioneerde mannen aan enkele categorieën varn activiteiten (uren per week) in 1980, Nederland.

\begin{tabular}{lccc}
\hline & Werkenden & Werklozen & Gepensioneerden \\
\hline Beroepsarbeid & 42 & & 1,3 \\
Huishouden & 7,7 & 15,0 & 14,5 \\
Slatap en verz & 72,4 & 80,5 & 82,2 \\
Sociale contacten & 9,6 & 13,5 & 12,2 \\
Massá media & 16,4 & 29,5 & 30,1 \\
Overige vrije-tijd & 15,8 & 23,8 & 23,0 \\
Rest & 4,2 & 4,7 & 4,8 \\
& & & \\
Bron : Knulst en Schoonderwoerd, 1983) & & \\
\hline
\end{tabular}

activiteiten die drinksituaties kunnen kenmerken, gepensioneerden brengen per week gemiddeld zo'n 24 uur meer door in situaties gekenmerkt door dit soort activiteiten. Uit de gegevens blijkt niet of de extra tijd voor bijvoorbeeld Massa-media, in de middaguren of in de avonduren is besteed. Met betrekking tot drankgebruik is dat een belangrijk verschil. De kans op drankgebruik bij Massa-media 's middags is bijvoorbeeld .06 (weekdagen, mannen), 's avonds is deze kans maar liefst .40. Hetzelfde geldt voor Sociale contacten, 's middags is de kans op drankgebruik hierbij .08 (weekdagen, mannen)'s avonds 38 (zie ook tabellen 3.4.1 en 3.4.2). De temporele lokatie van de extra te besteden uren is dus van belang.

Vergeleken met full-time werkende wrouwen hebben huisvrouwen, volgens Knulst en Schoonderwoerd (1983), 26\% en part-time werkende vrouwen $20 \%$ meer tijd te besteden. De verschillen in te besteden tijd die ontstaan door de verschillen in tijd besteed aan betaald werk worden hoofdzakelijk verdlisconteerd in de tijdsbesteding aan 'Gezinstaken en Huishouding'. De besteding van tijd aan verschillende categorieën van activiteiten voor de verschillende groepen vrouwen is weergegeven in tabel 4.1.2.

part-time werkenden besteden ten opzichte van werkende vrouwen per week dus slechts 6 uur meer aan de categorieën van actiwiteiten waarbij alcoholconsumptie als gebruikelijk mag worden beschouwd (Sociale contacten, Massa-media, Overige vrije tijdsbesteding en Rest). De huisvrouwen besteden aan deze activiteiten bijna 8 uur per week meer. Dit zou kunnen wijzen op een iets grotere gelegenheid tot drankgebruik. Net als bij de mannen is dat dan wel weer afhankelijk van de tijclen waarop de extra uren in 
Tabel 4.1.2

Tijdbesteding van werkende vrouwen, part-time werkende vrouwen en huiswrouwen aan verschillende categorieen van activiteiten (uren per week) in 1980, Nederland.

Werkenden Part-time Huisvrouwen

$\begin{array}{lrrr}\text { Beroepsarbeid } & 35,3 & 8,3 & 1,1 \\ \text { Huishouden } & 16,9 & 34,8 & 40,6 \\ \text { Slaap en verz. } & 74,1 & 76,0 & 76,2 \\ \text { Soc. kontakten } & 10,6 & 13,0 & 12,8 \\ \text { Massa media } & 12,0 & 13,9 & 15,5 \\ \text { Overige vrije-tijd } & 14,7 & 17,2 & 17,5 \\ \text { Rest } & 5,5 & 4,7 & 4,9\end{array}$

(Bron : Knulst en Schoonderwoerd, 1983)

drinksituaties zouden worden besteed. Naast Werk blijkt bij vrouwen (anders dan bij de mannen) ook de zorg voor kinderen een invloed op het tijdsbudget te hebben. Huisviouwen met kinderen hebben gemiddeld 8 uur minder, part-time werkenden 5 uur minder en werkenden 3 uur minder te besteden dan de vrouwern in dezelfde posities zonder kinderen.

In een Amerikaans onderzoek vergelijkt Hill (1985) de tijdbesteding van al dan niet getrouwde mannen en vrouwen, en binnen de categorie gehuwden die van full-time werkenden, part-time werkenden en niet werkenden. Hoewel de analyses oorspronkelijk gericht zijn op het verschil tussen mannen en vrouwen kunnen de gegevens ook worden geïnterpreteerd in het licht van de verschillen tussen mannen/vrouwen mèt en mannen/vrouwen zonder partner en mannen/vrouwen mèt of zonder baan. Hill presenteert de tijdbesteding in 7 hoofdcategorieën van activiteiten (tabel 4.1.3 en 4.1.4). Van deze 7 categorieèn bevalten er drie activiteiten waardoor drinksituaties kunnen worden gekenmerkt. Deze categorjeën zijn: Socjale contacten (onder andere visite), Passieve ontspanning (onder andere TV) en Actieve ontspanning.

Alleenstaanden besteden gemiddeld meer tijd aan activiteiten die drinksituaties kunnen kenmerken. Bij de gehuwden blijkt dat de deelname (in uren) aan dergelijke atctiviteiten afneemt met de werktijd, zij het bij mannen sterker dan bij wrouwen. Dit blijkt met natme uit de tijd besteed aan passieve ontspanning. Ook de gegevens van Hill tonen aan dat de structurerende positierollen van partner en full-time werkende de tijd doorgebracht in drinksituaties mogelijk beperken. 
Tabel 4.1 .3

De tijdbesteding van ongehwwde en gehuwde mannen aan verschillende categorieën van activiteiten (uren per woek) in de U.S.A.

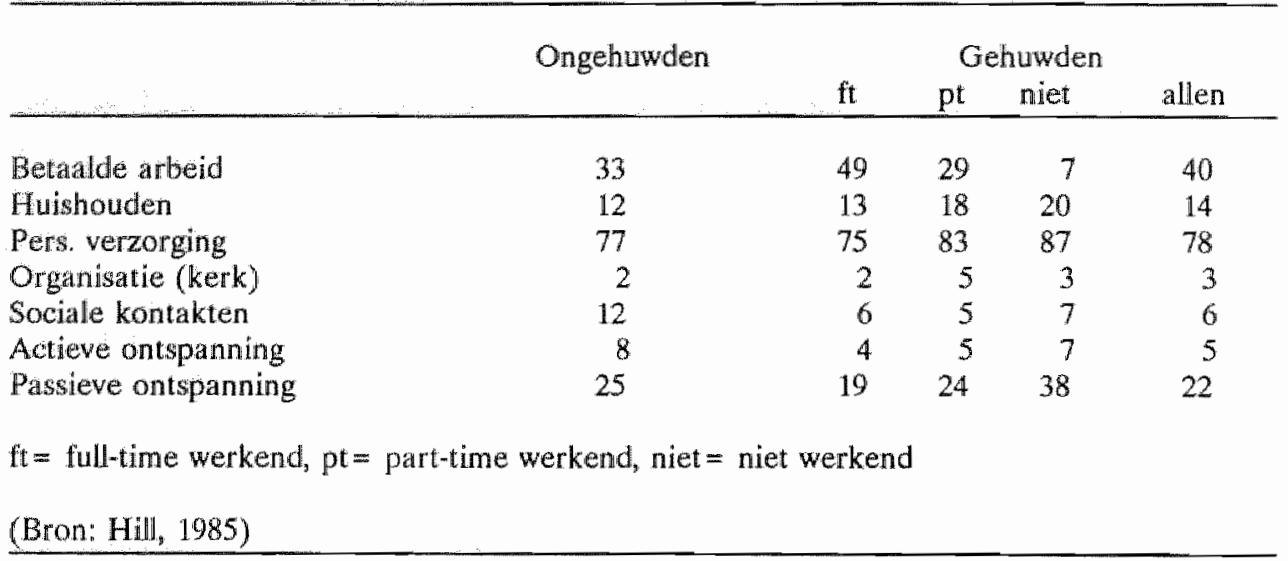

\section{Tabell 4.1.4}

De tijdbesteding van ongehuwde en gehuwde vrouwen aan verschillende categorieën van activiteiten (uren per week) in de U.S.A.

niet.

$$
\text { Ongehuwden }
$$

Betaalde arbeid

Huishouden

Pers. verzorging

Organisatie (kerk)

Sociale kontakten

Aktieve ontspanning

Passieve ontspanning

$$
\text { allen }
$$

Gehuwden $\quad \mathrm{ftpt}$

$\begin{array}{rrrr}39 & 20 & 3 & 17 \\ 25 & 33 & 41 & 35 \\ 74 & 77 & 82 & 79 \\ 2 & 3 & 4 & 3 \\ 7 & 8 & 8 & 8 \\ 3 & 4 & 6 & 5 \\ 18 & 22 & 24 & 22\end{array}$

$\mathrm{ft}=$ full-time werkend, $\mathrm{pt}=$ part-time werkend, niet $=$ niet werkend

(Bron: Hill, 1985) 
Zowel Knulst als Hill presenteren hun resultaten voor mannen en vrouwen afzonderlijk. Geslacht (statusrol) heeft een grote invloed op de tijdbesteding èn op de effecten van positierollen op die tijdbesteding. Bovenstaande gegevens, zowell die van Knulst als die van Hill, hebben als belangrijk nadeel dat ze niet zijn gecontroleerd voor andere statusrollen. Met name leeftijd als indicator voor levensfase, is een statusrol die sterk samenhangt met zowel tijdbesteding als met positierollen. Leeftijd is zo sterk verweven met de positierollen die mensen bekleden dat het bijna niet mogelijk is om de invloeden van deze statusrol en die van de positierollen (werk, partner, zorg voor kinderen) te scheiden. Bovenstaande gegevens zouden een vertekend beeld geven indien verschillen samenhangend met positierollen in feite verschillen tussen leeftijdscategorieën zouden zijn. Er zijn ook onderzoeken gedaan waarin wel met leeftijd en andere statusrollen rekening is gehouden.

Elchardus en van Rossem (1985) vergelijken de tijdsbesteding van werkende mannen met die van werkloze mannen uit het district Halle-Vilvoorde in Belgiè. Deze twee groepen mannen zijn op allerlei variabelen gematched. Er kan worden gesteld dat ze met uitzondering van hun 'tewerkstellingsstatuut' vergelijkbaar zijn. Verstorende effecten van andere variabelen, zoals bijvoorbeeld leeftijd, worden claardoor uitgesloten. De tijdsbesteding van de werkende en werkloze mannen uit het onderzoek van Elchardus en van Rossem is weergegeven in tabel 4.1.5.

De werkenden besteden gemiddeld 197 minuten op weekdagen en 533 op zondag ( 730 in totaal) aan activiteiten die drinksituaties kenmerken. De werklozen besteden aan dezelfde activiteiten gemiddeld respectievelijk 360 en 597 minuten. Qua tijd is in het 'natte' weekend de gelegenheid tot drankgebruik voor werklozen dus maar weinig groter. Dit bleek ook al uit de gegevens van Knulst. Of datzelfde ook voor de avonduren geldt kan uit deze gegevens niet worden afgeleid. Behalve de tijdsbesteding op zich is in dit onderzoek ook de betekenis die mensen aan hun activiteiten hechten onderzocht.

De auteurs constateren dat maar liefst $39 \%$ van de extra te besteden tijd van de werklozen wordt besteed aan verzorgende activiteiten (Huishouden, Karweitjes, Gezinstaken). Ze tonen verder aan dat de tijd besteed aan verzorgende activiteiten voor werkenden en werklozen in gelijke mate wordt verklaard door de hoeveelheid beschikbare tijd. Werklozen hebben meer beschikbare tijd en besteden daarom meer tijd aan verzorgende activiteiten en niet omdat ze werkloos zijn als zodanig. 
Tabel 4.1 .5

Gemiddelde tijdbesteding van werkende en werkloze mannen op weekdagen en op zondag (minuten per dag) in België.

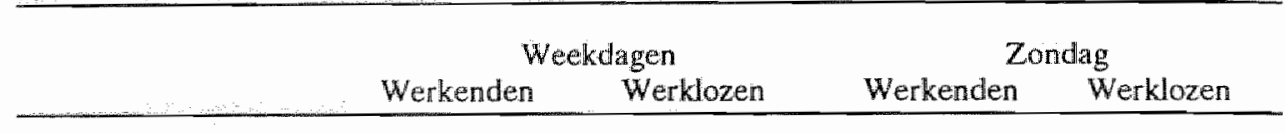

Arbeid

Totaal verzorgend

Diensten

Pers, werzorging

Eten en drinken

Slapen

Onderwijs

Participatie

Sociale contactern

Uitgaan

Hobby's, sport

Radio, TV

Lezen

Niets doen

Recreatie buiten

534

104

7
38
81
445
14
1
34
27
22
87
18
4
4

58

285

14

38

88

506

29

7

45

31

60

163

33

6

15
22

127

4
40
78
571
2
13
119
85
81
179
29
1
26

100

3

100

1

32

92

549

0

27

1.44

81

50

217

42

14

22

' Onder Arbeid vallen ook activiteiten in het kader van werkloosheid (bijvoorbeeld het stempelen dat in België verplicht is).

(Bron: Elchardus en van Rossem, 1985)

Algemene veronderstellingen die in hun onderzoek worden getoetst zijn:

1) Bezigheden hebben betekenissen, deze zijn belangrijk voor de zingeving van het leven.

2) In onze cultuur is Werk een activiteit met een belangrijke betekenis. Wanneer deze betekenis wegvait zal er evenwichtsherstellend gedrag optreden.

3) Dit gedrag kan bestaan uit:

a) gedragsverschuiving, meer tijd besteden an activiteiten die qua betekenis op Werk lijken.

b) betekenis verschuiving, het herdefiniëren van activiteiten met de bedoeling deze meer de betekenis van Werk te geven. 
De betekenissen die aan verzorgende actiwiteiten worden gegeven blijken meer dan bij andere activiteiten op de betekenis van Werk te lijken. In het algemeen is de toename in de tijd besteed aan bepaalde activiteiten groter naarmate deze activiteiten meer op Werk lijken. Verder blijkt dat werklozen hun activiteiten herdefiniëren op een manier die de betekenis van Verzorgende activiteiten nog dichter bij die wan Werk brengt (Glorieux, 1989).

Uit de bovenbeschreven processen en uit het feit dat verzorgende activiteiten niet met drinksituaties samen gaan zou kunnen worden afgeleid dat in geval van werkloosheid activiteiten die drinksituaties kenmerken waarschijnlijk niet geüntensiveerd zullen worden. Als er een betekenisverschuiving van activiteiten optreedt zal deze in de richting van de betekenis van Werk zijn. Werk gaat niet samen met alcoholgebruik.

Uit nog weer een andere analyse van dezelfde gegevens (Elchardus en Glorieux, 1987) blijkt dat de betekenis die aan activiteiten wordt gegeven, sterk wordt gedomineerd door het arbeidsritme. Het tijdstip waarop activiteiten plaatsvinden is minstens zo belangrijk in de betekenisgeving aan die activiteiten als de 'objectieve' of 'lexicale' betekenis van die activiteiten. Bepaalde dagdelen hebben bepaalde betekenissen. De ochtend en namiddag hebben een duidelijk sociale betekenis ('Tk heb deze activiteit gesteld ondat ik het als mijn plicht beschouw'). Niet alleen voor de werkenden maar ook voor de werklozen. De avond staat meer in het teken van de persoonlijke behoeftebevrediging (motivatie: 'ik heb deze activiteit gesteld omwille van het plezier en genoegen dat ik er aan beleef') (Elchardus en Glorieux, 1987).

Vrije-tijds activiteiten worden sterk gekenmerkt door deze laatste betekenisgeving. De extra te besteden uren van de werklozen vallen op tijden die qua zingeving niet als risico-tijden voor alcoholgebruik kunnen worden gezien. In de avonduren blijkt de betekenis die werkenden en werklozen aan hun handelen geven nagenoeg identiek te zijn. Wel moet worden aangetekend dat bij de werklozen de, qua betekenis, 'vrije' avond iets eerder begint dan bij de werkenden. Dit zou weer in kunnen houden dat ze ook eerder beginnen met drinken.

Al met al zijn er in de literatuur voldoende aanwijzingen om te mogen veronderstellen dat een gebrek aan structurerende positierollen zal leiden tot een toename in tijdbesteding binnen drinksituaties en aldus tot een verhoogde alcoholconsumptie. Zowel de rol van werkende als die van partner of die van verzorger van jonge kinderen (alleen vrouwen) hebben invloeden op de besteding van tijd aan bepaalde groepen van activiteiten waaruit afgeleid mag worden dat ze de gelegenheid tot drankgebruik beperken.

Zoals uit bovenstaande bleek is er op weekend-dagen nagenoeg geen verschil in de tijcbesteding van werkenden en werklozen. Of er in de avonduren verschillen zijn kon uit de genoemde studies niet worden achterhald. In geval wan het ontbreken of wegvallen van de positierol van werkende valt de extra te besteden tijd voornamelijk in de ochtend en de middag van weekdagen. De toename in het drankgebruik zou zich daarom dan ook voornamelijk in de zogenaamde droge drinksituaties voor moeten doen.

Ook het belang van statusrollen komt in de literatuur met betrekking tot tijdbesteding tot uiting (Szalai, 1972; Knulst en Schoonderwoerd, 1983). Statusrollen bieden een algemene gedragsoriëntatie die tot grote verschillen in tijjdbesteding kan leiden. Zeer duidelijk komt dit tot uiting in verschillen tussen mannen en vrouwen. Ook de toegang tot positierollen wordt gedeeltelijk door statusrollen bepaald. Naast geslacht is leeftijd hierin een heel belangrijke statusrol. Leeftijd is een van de statusrollen die tijdbesteding, alcoholgebruik (Middleton Fillmore, 1987) en positierollen die mensen vervullen, bepaalt. Dit bemoeilijkt onderzoek naar de relatie tussen positierollen en drankgebruik. Het effect van pensionering bijvoorbeeld, kan 
moeilijk worden onderzocht omdat gepensioneerden over het algemeen ouder zijn dan werkenden. Ook de relaties van positierollen met drankgebruik op jongere leeftijd zijn moeilijk te onderzoeken daar er in de adolescentie en jonge volwassenheid (tot ongeveer 25 jaar) een groot aantal rollen veranderen (Power, 1989). De rol van scholier/student wordt verwisseld voor die van werkende (of werkloze), welen stichten een gezin (partnerrol, rol van verzorger etc.). Al deze veranderingen in rollen zijn sterk gebonden aan leeftijd. Het is in deze gevallen moeilijk de efiecten van leeftijd en postierollen op tijdbesteding of alcoholconsumptie te scheiden. Volgens Young (1988) is er na de kindertijd geen sprake meer wan 'ages' maar meer van 'stages', positierollen zouden volgens zijn redenering sterker bepalend zijn voor de gedragsoriëntatie dan de chronologische leeftijd. Met deze verwevenheid van status- en positierollen moet in de analyse van de gelegenheid to drankgebruik rekening worden gehouden.

Mogelijke verbanden tussen positie- en statusrollen en de gelegenheid om te drinken zijn alleen interessant indien er een verband is tussen gelegenheid en consumptie. Aangenomen word dat naarmate men langer in drinksituaties verblijft men ook meer consumeert. Wanneer er een verband tussen expositie aan drinksituaties en consumptie bestaat dan zal dit verband waarschijnlijk het sterkst zijn in cle 'natte situaties". Deze zijn gedefinieerd als situaties waarin $50 \%$ of meer van de deelnemers drinkt. Hoewel het volgens deze definitie niet noodzakelijk zo is dat men meer dan 1 consumptie nuttigt in dergelijke situaties is het wel aannemelijk dat dit verband tussen expositieduur en consumptie in 'natte' situaties sterker is dan in 'medium' of 'droge' situaties.

\subsection{Vragen en veronderstellingen}

In het voorafgaande is uiteengezet op welke wijze positierollen en statusrollen al dan niet door middel van de tijdbesteding samen kunnen hangen met sociaal geaccepteerd alcoholgebruik. Er zijn enkele algemene onderzoekswragen en een aantal veronderstellingen ten aanzien van de relaties tussen rollen, gelegenheid tot drankgebruik en consumptie geformuleerd. In deze paragraaf worden deze proposities nog eens op een rijtje gezet.

Per definitie is het onmogelijk om in een bepaalde situatie te drinken wanneer men zich niet in die situatie bevindt. De expositie aan drinksituaties is daarmee een noodzakelijke woorwalarde voor de consumptie van alcoholhoudende dranken binnen die situaties. Het is echter geen voldoende voorwaarde. Gegeven de expositie zal er binnen een drinksituatie drinkgedrag moeten worden gerealiseerd wil er sprake zijn van alcoholconsumptie.

\section{Proposities: expositie en consumptie}

Binnen de verklaring van variaties in drankgebruik kunnen twee fases worden onderscheiden. In de eerste fase wordt de nadruk gelegd op de expositie aan drinksituaties als verklarende factor voor de consumptie. De centrale veronderstelling in deze fase is:

I Hoe groter de expositie an drinksituaties hoe hoger de consumptie.

Een specifiekere veronderstelling is dat de relatie expositie-consumptie sterker zal zijn naarmate de kans op drankgebruik binnen drinksituaties groter is: 
Hoe groter de kans op drankgebruik binmen drinksituaties thoe sterker de relatie tussen expositie aan die situaties en consumptie in die situaties.

Deze tweede verondersteliing lijkt wellicht tautologisch, ze is dat echter niet. De kans op drankgebruik is gedefinieerd als: het aantal drinkers binnen een drinksituatie gedeeld door het aantal deelnemers aan die situatie. Het is een contextuele variabele die de aard van de drinksituaties omschrijft. Deze is voor alle deelnemers aan een situatie gelijk. De kans op drankgebruik geeft informatie over het al dan niet drinken wan alle deelnemers aan een drinksituatie. Binnen eenzelfde context kunnen echter de expositie aan en de consumptie in die context per deelnemer variëren. Expositie en consumptie kunnen op interval-niveau gemeten worden. De relatie tussen expositie en consumptie geeft informatie over de hoeveelheid die wordt gedronken.

\section{Proposities: rollen en expositie}

Centraal in dit hoofdstuk staat de relatie tussen de structuur van het dagelijks leven en de consumptie van alcoholhoudende dranken. De structuur van het dagelijks leven hangt samen met de positierollen die de sociale actor vervult. Positierollen bepalen voor een deel de wijze waarop men zijn tijd kan besteden. Een gebrek aan structurerende positierollen leidt tot een grotere hoeveelheid vrij te besteden tijd. Er wordt hier verondersteld dat een gebrek aan structurerende positierollen ook leidt tot een hogere expositie aan drinksituaties.

III Het ontbreken van structurerende positierollen leidt tot een hogere expositie aan drinksituaties.

Verschillen in tijdsbesteding tussen mensen met en mensen zonder betaalde werkkring blijken met name gelokaliseerd te zijn op de middagen en ochtenden van weekclagen. Drinksituaties die op deze tijden zijn gelokaliseerd zijn bijna allemaal droge situaties. Daarom kan worden verondersteld:

IV De negatieve relatie tussen de structurerende rol van werkende en de expositie is het sterkst in droge drinksituaties.

Behalve de rol van werkende hebben ook de structurerende positierollen partner en verzorger van jonge kinderen invloeden op de tijdsbesteding. Ze resulteren in een kleinere hoeveelheid vrij te besteden tijd. De temporele lokatie van de verschillen in tijdsbesteding van degenen met partner en/of kinderen en degenen die een van die twee of beide structurerende rollen niet vervullen is echter niet uit de literatuur af te leiden. Hieromtrent worden dan ook geen specifieke veronderstellingen geformuleerd.

Statusrollen hangen samen met alcoholconsumptie en met de wijze waarop sociale actoren hun tijd besteden. Er kan worden verondersteld dat de expositie aan drinksituaties verschilt naar statusrollen en aldus verschillen in consumptie teweeg kan brengen. Indien deze veronderstelling opgaat zou het volgende moeten gelden: 
$\checkmark \quad$ Bij gelijke positierollen verkdaren statusrollen verschillen in de expositie aan drinksituatties.

Ten aanzien van de richting van deze verbanden worden geen specifieke veronderstellingen geformuleerd.

Samenvattend, positierollen beïnwoeden de expositie aan drinksituaties. Statusrollen kunnen verschillen in expositie binnen positierollen nader verklaren. De expositie op haar beurt beïnvloedt de consumptie binnen die drinksituaties.

\section{Proposities: rollen en realisatie}

Behalve door verschillen in de gelegenheid om te drinken, kunnen er door de mate waarin van deze gelegenheid gebruik wordt gemaakt (intensiteit) verschillen in consumptie ontstaan. Op grond van de redenering zoals expliciet gemalkt door Knibbe (1984) wordt hier de veronderstelling geformuleerd dat een gebrek aan structurerende positierollen zal leiden tot een hogere mate van realisatie wan drinkgedrag bij gelijke expositie.

VI Het ontbreken van structurerende positierollen thangt positief samen met de mate waarin drankgebruik wordt gerealiseerd.

Categorieën van drinkers die zeker verschillen met betrekking tot de mate waarin ze drinkgedrag realiseren zijn de zware, matige en lichte drinkers zoals gedefinieerd in hoofdstuk 3. De verschillen tussen deze categorieën van drinkers zijn het grootst binnen droge situaties. Als dit mag worden gegeneraliseerd kan worden gesteld:

VII Systematische verschillen in realisatie van drinkgedrag blijken met name in droge drinksituaties.

De verschillen tussen mannen en vrouwen beschreven in de resultaten van hoofdstuk 3 , wijzen erop dat geslacht als statusrol zeer grote verschillen in consumptie teweeg kan brengen. Ook deze verschillen uiten zich het sterkst binnen zogenaamde droge situaties. Naast geslacht zijn religie, sociale klasse en leeftijd statusrollen waarvan herhaaldelijk is aangetoond dat ze met de alcoholconsumptie samenhangen (Sijlbing, 1978; Knibbe, 1984). Of deze samenhangen voortkomen uit relaties tussen statusrollen en expositie dan wel uit de relaties tussen statusrollen en de mate van realisatie van drinkgedrag kan uit de literatuur niet worden afgeleid. Het meest aannemelijk is dat ze zowel met expositie als met realisatie samenhangen.

VIII Er zijn verbanden tussen statusrollen en de mate waarin drankgebruik wordt gerealiseerd.

De mate waarin drankgebruik wordt gerealiseerd kan op verschillende niveaus worden beschouwd. Er kan een onderscheid worden gemaakt tussen factoren die samenhangen met het al dan niet drinken wanneer men aan een drinksituatie deelneemt en factoren die samenhangen met de hoeveelheid die wordt gedronken. Uit de literatuur is gebleken dat de wijze waarop 
consumptie wordt geoperationaliseerd samenhangt met de relaties die kunnen worden gevonden. Met deze mogelijkheid zal in de analyses rekening worden gehouden.

Samenvattend, naast verschillen in expositie kunnen ook verschillen in realisatie leiden tot verschillen in consumptie. Factoren die de expositie beïnvloeden kunnen, al is dat niet noodzakelijk, ook de realisatie beinvloeden. Samenhangen tussen factoren en realisatie van drankgebruik kunnen alleen worden vastgesteld wanneer voor expositie wordt gecontroleerd. Er zijn geen redenen om aan te nemen dat de invloeden van rollen op de realisatie van drinkgedrag dezelfde richting hebben als de invloeden op expositie aan drinksituaties. Een rol kan positief samenhangen met expositie en tegelijkertijd negatief met de realisatie. Dit zou tot gevolg kunnen hebben dat er geen verband tussen die rol en de consumptie kan worden gevonden. Er zijn eveneens geen redenen om aan te nemen dat rollen en expositie of realisatie in alle drinksituaties in dezelfde richting zullen samenhangen. Wanneer een rol positief samenhangt met de consumptie in droge situaties maar negatief met die in natte situaties kàn dit tot gevolg hebben dat er geen verband tussen die rol en de totale consumptie wordt gevonden.

Dergelijke processen zouden er de reden van kunnen zijn dat er vaak verschillende relaties tussen positierollen en alcoholgebruik worden gevonden. Om een duidelijk inzicht in het drinkgedrag te verkrijgen zullen hier zowel de expositie als de realisatie worden bestudeerd, zal er een onderscheid tussen de verschillende drinksituaties wordien gemaakt en zal de consumptie op werschillende manieren worden geoperationaliseerd.

\section{Proposities: consumptieniveau en rollen}

In hoofdstuk 3 zijn op basis van drinkfrequentie een drietal categorieèn drinkers gedefinieerd. Lichte, matige en zware drinkers verschillen zondermeer in de mate waarin ze tijdens de dagboekweek gelegenheden tot drankgebruik realiseren. Indien de in het voorafgaande geformuleerde veronderstelde verbanden tussen rollen en expositie aan of consumptie in drinksituaties zouden worden bevestigd zou dat ook tot uiting moeten komen in de relaties tussen rollen en de verdeling van drinkers over frequentie-categorieën. Verwachtingen over relaties tussen structurerende positierollen en de verdeling in antal zware, matige en lichte drinkers kunnen als volgt worden geformuleerd:

IX Er zijn negatieve verbanden tussen structurerende positierollen en drinkfrequentie.

Met betrekking tot de verbanden tussen statusrollen en drinkfrequentie kan worden gesteld:

X Er zijn verbanden tussen statusrollen en drinkfrequentie.

\subsection{Methode}

\subsubsection{Inleiding}

De analyse van de verbanden tussen de structuur van het dagelijks leven, statusrollen, de expositie aan drinksituaties en drankgebruik kan op verschillende aggregatie-niveaus worden uitgewoerd. Er kan worden uitgegaan van de totale expositie aan drinksituaties en het totale 
drankgebruik, van de expositie aan categorieén van drinksituaties (geordend naar de kans op drankgebruik) en het drankgebruik per categorie van situaties of van de expositie aan de afzonderlijke situaties en het drankgebruik per situatie. De totale expositie is de som van de expositie aan ellk van de cattegorieèn van situaties en deze zijn op hun beurt de som van de expositie aan elk wan de afzonderlijke situaties in die categorie. Analyses van het totale drankgebruik veronderstellen dat factoren die drankgebruik beinvioeden in alle situaties op gelijke wijze van invloed zijn. In de vorige paragraafi is reeds uiteengezet dat dit niet het geval behoeft te zijn. Daarom wordt hier het drankgebruik binnen droge, medium en natte situaties afzonderlijk geanalyseerd. Idealiter zou de expositie en consumptie per afzonderlijke situatie moeten worden geanalyseerd. Het aantal deeinemers en drinkers per situatie is echter binnen de gebruikte steekproef in het merendeel der situaties niet groot genoeg om dergelijke analyses uit te kunnen voeren. Ook de totale expositie en consumptie zullen worden geanalyseerd. Zo kan vastgesteld worden of, en zo ja in welke gevallen, de effecten van rollen op expositie en realisatie, dan well de effecten binnen verschillende categorieën van drinksituaties, elkaar opheffen.

Alvorens de wijze van analyseren per categorie van drinksituaties te beschrijven (paragraaf 4.3.4), zal eerst worden beschreven hoe de positie- en statusrollen alsmede de gelegenheid tot drankgebruik en het drankgebruik zelf, zijn geoperationaliseerd (paragraaf 4.3.2) en worden de proposities zoals gegeven in paragraaf 4.2 vertaald in operationele hypothesen (paragraaf 4.3.3).

\subsubsection{De variabelen}

Er kunnen drie groepen variabelen worden onderscheiden:

1) De rolvariabelen.

2) De variabelen met betrekking tot de gelegenheid tot drankgebruik (expositie).

3) De variabelen met betrekking tot het drankgebruik.

De rolvariabelen kunnen verdeeld worden in positierol-variabelen en statusrol-variabelen.

De positierolvariabelen hebben betrekking op de differentiatie in rollen van (niet-) werken, partner en ouder/opvoeder.

De verschillende rollen die binnen elk van deze categorieën worden onderscheiden en het aantal respondenten dat deze rollen vervult zijn weergegeven in tabel 4.3.1. Structurerende rollen kunnen onderscheiden worden van niet-structurerende rollen. Structurerende rollen zijn: studeren, full-time werk, partner en de zorg voor jonge kinderen. Binnen de vrouwelijke populatie komt naast full-time werken en studeren ook nog de structurerende huisvrouw-rol voor.

De statusrollen die in de analyses gehanteerd zullen worden zijn: geslacht, leeftijd, sociale klasse en relligie.

Geslacht is niet als een variabele gebruikt. Alle analyses zijn voor mannen en vrouwen afzonderlijk verricht.

Leeftijd is onderverdeeld in de klassen 'jonger dan 25 jaar', '25-34 jaar', '35-44 jaar', '45-54 jaar', '55-64 jaar' en '65 jaar of ouder" (de Bie, 1987).

Als indicator voor Sociale klasse is beroepsniveau (schaal ITS, Westerlaak et al., 1975) gebruikt. Deze variabele is verdeeld in twee categorieën: de lagere en de hogere sociale klassen. De lagere klassen bevat de ongeschoolde en geschoolde arbeiders alsmede de lagere employees. De 
hogere klassen bestaat uit de kleine zelfstandigen $(\mathrm{n}=75)$ en de middelbare en hogere employées.

Met betrekking tot Religie worden vier categorieèn onderscheiden, te weten geen religie, roomsm katholiek protestant en anders.

Tabel 4.3 .1

Frequentie van verschillende positierollen in de onderzoekspopulatie.

Mannen

Vrouwen

Arbeidsrol

Full-time werkenden

116

-part-time
-studerenden
-werklozen
-arbeidsongeschikten
-gepensioneerden

Niet Full-time werkenden

Huisvrouw/man

Partnerrol

Partner

-alleen

-ouders

-andere volwassenen

Geen Partner

Verzorgersrol

-kind jonger dan 4 jar

Jonge kinderen

-kind van 13-18 jaar

-kind ouder dan 19

-kind niet thuis

-geen kinderen 
De gelegenheid tot drankgebruk is geoperationaliseerd als de expositie aan ofwel de tijd doorgebracht binnen drinksituaties. De gelegenheid tot drankgebruik per drinksituatie is gelijk gesteld aan het aantal hwartieren dat binnen die situatie is doorgebracht tijdens de dagboekweek.

De gelegenheid tot drankgebruk per categorie van situaties is de som van de tijd die tijdens de dagboekweek in elk van die situaties is doorgebracht. Deelnemers an een categorie van drinksituaties zijn diegenen die minstens een kwartier in een van de tot die categorie behorende situaties hebben doorgebracht.

De expositie aan natte situaties is geoperationaliseend als de som van de tijd doorgebracht in elk der drinksituaties warbinnen meer dan $50 \%$ wan de deelnemers drinkt. De scores op deze variabele bleken niet normal te zijn verdeeld. Door middel van een worteltransformatie is de verdeling genormaliseerd.

De expositie aan medium situaties is geoperationaliseercl als de som van de tijd doorgebracht in elk der drinksituaties warin tussen de 20 en $50 \%$ van de deelnemers drinkt.

Daar de relatie tussen rollen en de expositie aan dan wel consumptie binnen drinksituaties in dit hoofdstuk central stat zijn drinksituaties gekenmerkt door activiteiten die rechtstreeks met positierallen samenhangen buiten de anallyes gelaten. Bij de mannen betreft dit de drinksituaties gekenmerkt door de activiteit Werk. Bij de vrouwen betreft het de drinksituaties gekenmerkt door de actiwiteit Huishouden. Zoals reeds uit de discussie bij hoofdstuk 3 bleek zijn er enkele situaties warin de kans op drankgebruik $(p<.05$ ) zeer laag is (slaap en persoonlijke verzorging) als drinksituaties gedefinieerd. Ook deze situaties worden in dit hoofdstuk niet in de analyses betrokken.

De expositie aan droge situaties is geoperationaliseerd als de som van de tijd doorgebracht in elk der drinksituaties warbinnen tussen 5 en $20 \%$ van de deelnemers drinkt, met uitzondering van die drinksituaties gekenmerkt door de activiteit Werk bij de mannen en de activiteit Huishoudelijk Werk bij de wrouwen (bij de vrouwen zijn er geen drinksituatie die door de activiteit Werk worden gekenmerkt).

De totale expositie tenslotte, is geoperationaliseerd als de som van de expositie aan droge, medium en natte situaties, met uitzondering van die drinksituaties gekenmerkt door de activiteit Werk bij de mannen en de activiteit Huishoudelijk Werk bij de vrouwen. In tabellen 3.4.1 en 3.4 .2 is a angegeven welke drinksituaties tot welke categorie behoren.

Het daadwerkelijke drankgebruik is op verschillende manieren geoperationaliseerd. Dit is gedan ondat uit de literatuur (Crawford et al., 1987; van der Horst, 1988) bleek dat verschillen in de operationalisatie van drankgebruik tot verschillende resultaten kunnen lejden. Er wordt een onderscheid gemaakt tussen het al dan niet drinken binnen een categorie van drinksituaties en de consumptic in die situaties.

De variabelen met betrekking tot consumptie zijn analoog aan die van de expositie-variabelen geoperationaliseerd. De eenheid van consumptie is het drinkkwartier. Eien drinkkwartier kan, op een enkele uitzondering na, gelijk gesteld worden aan eén alcoholische consumptie. De consumptie wordt uitgedrukt in het aantal gerapporteerde drinkkwartieren per categorie van drinksituaties. Drinkers binnen een categorie van drinksituaties zijn diegenen die minstens een drinkkwartier gerapporteerd hebben binnen een van de tot die categorie behorende situaties. De consumptie bimten natte simaties is geoperationaliseerd als het totaal aantal gerapporteerde drinkkwartieren binnen situaties warin meer dan 50\% van de deelnemers drinkt. 
De consumptie binnen medium situaties is geoperationaliseerd als het total aanthl gerapporteerde drinkkwartieren binnen drimksituaties warin tussen de 20 en $50 \%$ van de deehemers drinkt.

De consumptie binnen droge situaties is geoperationaliseerd als het total aantal gerapporteende drinkkwartieren binnen drinksituaties waarin tussen de 5 en $20 \%$ van de deelnemers drinkt, met uitzondering van die drinksituaties gekenmerkt door de activiteit Werk bij de mannen en de activiteit Huishoudelijk Werk bij de vrouwen.

De totale consumptie tenslotte, is de som van de consumptie binnen natte, medium en droge situaties, met uitzondering van die drinksituaties gekenmerkt door de activiteit Werk bij de mannen en de activiteit Huishoudelijk Werk bij de vrouwen.

De verdelingen van de consumptie-variabelen voldeden niet aan de eis van normaliteit die in veel statistische analyses wordt gesteld. Ook deze verdelingen zijn door middel wan een worteltransformatie genormaliseerd.

\subsubsection{De operationele hypothesen}

In deze paragraaf worden de proposities zoals geformuleerd in paragraaf 4.2 in operationele hypothesen vertald. Aan de hand van deze hypothesen zullen de resultaten van de analyses worden gepresenteerd (hoofdstuk 5 en 6). Bij de presentatie van de hypothesen en de resultaten is uitgegaan van de logische volgorde in de totstandkoming van drinkgedrag. Dat wil zeggen dat eerst bypothesen omtrent de expositie worden geformuleerd. Daarna worden hypothesen over de relatie tussen expositie en consumptie geformuleerd. Vervolgens komen de hypothesen betreffende de relaties tussen rollen en de intensiteit van drinkgedrag aan de orde.

\section{Hypothesen over rollen en expositie}

Binnen structurele verklaringen van het drankgebruik is de expositie aan drinksituaties een centrale variabele. Samenhangen tussen rollen en expositie zijn geformuleerd in proposities III, IV, en V. Deze proposities zijn als volgt vertaald in operationele termen:

\section{hypothese 1}

Mensen met structurerende positierollen brengen gemiddeld minder tijd door in drinksituaties dan mensen die zulke rollen niet vervullen.

\section{hypothese 2}

Verschillen in de tijd doorgebracht binnen drinksituaties tussen mensen met en mensen zonder werk zijn het grootst in droge drinksituaties.

\section{hypothese 3}

Statusrollen verklaren een deel van de variantie in tijd doorgebracht binnen drinksituaties, die overblijft na controle voor positierollen.

\section{Hypothesen over expositie en consumptie}

De centrale hypothese binnen het geheel van verklaringen van verschillen in comsumptie uit structurele kenmerken van het dagelijks leven is: 


\section{hypothese 4}

Hoe meer tijd men doorbrengt in een categorje van drinksituaties hoe hoger de alcoholconsumptie in die situaties.

Propositie II specificeert deze eerste veronderstelling. In operationele termen luidt deze:

\section{hypothese 5}

De relatie tussen de tijd doorgebracht in categorieèn van drinksituaties en de consumptie van alcohol in die drinksituaties neemt in sterkte toe met de natheid van de drinksituaties.

Deze hypothesen lijken vanzelfsprekend. Aangetekend moet worden dat hier relaties verondersteld worden tussen de totale tijd die men gedurende een week in drinksituaties doorbrengt en de totale alcoholconsumptie. Dit maakt de vanzelfsprekendheid van het verband a minder vanzelfsprekend. Verder is het belang van deze hypothesen gelegen in het feit dat tot nu toe, in alcoholonderzeok de gelegenheid om te drinken nooit direct werd geoperationaliseerd.

\section{Hypothesen over rollen en realisatie}

De relaties tussen rollen en consumptie worden op twee niveaus onderzocht. Enerzijds is het al dan niet drinken binnen een categorie van drinksituaties de afhankelijke variabelle. Anderzijds is de hoogte wan de consumptie in een categorie van drinksituaties de afhankelijke variabele. De vertalingen van proposities VI, VII en VIII in operationele termen luiden:

\section{hypothese 6}

Bij respondenten met structurerende rollen is het percentage drinkende deelnemers in drinksituaties lager dan bij respondenten zonder structurerende rollen.

\section{hypothese 7}

De gemiddelde consumptie in een categorieèn van drinksituaties is, na controle voor de expositie aan die situaties, lager in categorieèn van drinkers met structurerende rollen dan in categorieen wan drinkers zonder structurerende rollen.

\section{hypothese 8}

In nattere drinksituaties zijn verbanden tussen structurerende rollen en het percentage drinkers binnen categorieen van drinksituaties minder sterk.

\section{hypothese 9}

In nattere drinksituaties zijn verbanden tussen structurerende rollen en de gemiddelde consumptie na controle voor expositie, van drinkers in drinksituaties, minder sterk.

Behalve van positierollen is ook van statusrollen verondersteld dat ze samenhangen met intensiteit van drinkgedrag. Zoals nog duidelijk zal worden gemaakt in paragraaf 4.3 .4 is de statusrol leeftijd niet als variabele gebruikt. De operationele hypothesen op basis van propositie VII hebben alleen betrekking op de statusrollen religie en sociale klasse. 


\section{Hypothese 10}

Na controle voor positierollen verklaren statusrollen een deel van de variantie in thet percentage drinkers binnen categorieën van drinksituaties.

\section{Hypothese 11}

Na controle voor expositie en positierollen verklaren statusrollen een deel van variantie in de consumptie binnen categorieën van drinksituraties.

\section{Hypothesen over consumptieniveau en rollen}

Propositie IX en X betreffen relaties tussen consumptie-niveau en rollen. De operationele hypothesen bij deze propositie betreffen alle leeftijdscategorieërn samen.

\section{Hypothese 12}

Het percentage zware drinkers is lager in categorieën van respondenten met structurerende rollen dan in categorieën van respondenten zonder structurerende rollen.

\section{Hypothese 13}

De verdeling van de populatie in lichte, medium en zware drinkers varieert met statusrollen.

De zwaarte van het drinkgedrag is gebaseerd op de drinkfrequentie in de dagboekweek. Volgens de hier gehanteerde definitie hebben zelfs lichte drinkers (gemiddeld) een drinkfrequentie van minstens een keer per week. Het is mogelijk dat de verschillen tussen categorieën drinkers niet extreem genoeg zijn. Wellicht dat verbanden tussen rollen en drankgebruik zich met name uiten in verschillen tussen mensen die een lagere drinkfrequentie hebben en de mensen die een keer per week of vaker drinken. De hypothesen worden dan:

\section{Hypothese 14}

Het percentage van de populatie dat tijdens de dagboekweek niet heeft gedronken is lager in categorieën van respondenten met structurerende rollen dan in categorieën van respondenten zonder structurerende rollen.

\section{Hypothese 15}

Het percentage van de populatie dat tijdens de dagloekweek niet heeft gedronken varieert met statusrollen. 


\subsubsection{De analyses}

De anallyses kunnen in drie categorieen worden onderverdeeld:

1. Analyses betreffende de factoren die samenhangen met het al dan niet drinken bij deelname aan drinksituaties. Deze analyses zijn per categorie van drinksituaties verricht door middel van logit-analyses.

2. Analyses betreffende de duur van de expositie aan drinksituaties en de hoogte van de consumptie. Deze analyses zijn verricht door middel van multiple regressie. Per categorie van drinksituaties is onderzocht welke factoren samenhangen met de duur van de expositie van de deelnemers aan die drinksituaties en de hoogte van de consumptie van de drinkers in die situaties.

3. Analyses betreffende relaties tussen rollen en de zwaarte van het drankgebruik. Deze analyses zijn verricht door middel van $X^{2}$-toetsen.

Uitgaande van de theoretische overwegingen gepresenteerd in het kader van de structurele verklaringen van verschillen in drankgebruik, zouden effecten van statusrollen moeten worden wastgesteld na controle voor effecten van positierollen. De variabele leeftijd hangt zeer nauw samen met de positierollen die mensen vervullen. Dit is in zeer extreme mate het geval met de positierollen ten aanzien van de zorg voor jonge kinderen en werk. Sommige rollen komen in bepaalde leeftijdscategorieën nawwelijks voor. Daar komt nog bij dat leeftijd niet rechtlijnig samenhangt met de alcoholconsumptie (zie tabel 4.3.2) terwijl dit wel een uitgangspunt is van met name de multiple regressie analyse.

Om interpretatieproblemen te woorkomen zou, als er strikt van het theoretische model wordt uitgegaan, de invloed van leeftijd per positierol kunnen worden onderzocht. Deze analyse sluit echter toetsing van verschillen tussen positierollen uit. Omdat de structuur van het dagelijks leven een centraal begrip in het verklaringsmodel wormt is gekozen voor afzonderlijke analyses per leeftijdscategorie. De leeftijdscategorieën zijn samengesteld op basis van de relatie tussen leeftijd en positierollen. De categorieën zijn zo gekozen dat de verdeling van positie-rollen daarbinnen zo homogeen mogelijk is. Daarbij is er naar gestreefd de categorieën zo groot mogelijk te houden. 
Tabel 4.3.2

De gemiddelde consumptie in drinkkwartieren (DT) en het aantal drinkers (DN) per categorie wan drinksituaties naar leeftijd voor mannen en vrouwen afzonderlijk.

\begin{tabular}{|c|c|c|c|c|c|c|}
\hline \multirow{2}{*}{$\begin{array}{l}\text { Leeftijds- } \\
\text { categorie }\end{array}$} & \multicolumn{6}{|c|}{ Aard drinksituaties } \\
\hline & DT & DN & DT & DN & DT & DN \\
\hline
\end{tabular}

\section{Manmen}

$\begin{array}{lrrrrrr}\text { 16-24 jaar } & 2.9 & 28 & 4.5 & 41 & 10.6 & 45 \\ 25-34 \text { jaar } & 4.7 & 67 & 9.8 & 87 & 9.8 & 77 \\ 35-44 \text { jaar } & 5.4 & 72 & 9.5 & 92 & 7.3 & 59 \\ \text { 45-54 jaar } & 4.8 & 37 & 9.0 & 60 & 7.7 & 36 \\ 55-64 \text { jaar } & 3.0 & 34 & 8.0 & 46 & 4.0 & 2.1 \\ \text { ouder dan 64 jaar } & 10.6 & 9 & 6.9 & 10 & 3.0 & 2 \\ \text { Alle mannen } & 4.7 & 247 & 8.6 & 336 & 8.4 & 240\end{array}$

Vrouwen

\begin{tabular}{lrrrrrr} 
16-24 jaar & 3.3 & 21 & 4.8 & 32 & 6.1 & 22 \\
25-34 jaar & 3.9 & 50 & 5.1 & 59 & 3.6 & 10 \\
35-44 jaar & 5.4 & 44 & 5.5 & 52 & 4.0 & 11 \\
45-54 jaar & 3.6 & 32 & 4.7 & 34 & 1.3 & 3 \\
55-64 jaar & 3.2 & 30 & 3.2 & 25 & 2.0 & 1 \\
ouder dan 64 jaar & 5.6 & 11 & 3.4 & 10 & 0.0 & 0 \\
Alle vrouwen & & & & & & \\
\hline
\end{tabular}

Bij de mannen worden vier leeftijdscategorieën onderscheiden. De categorie jongeren $(\leq 24$ jaar) is de enige leeftijdscategorie waarin de rol van scholier/student voorkomt. De rol van verzorger/opvoeder komt in deze categorie nauwelijks voor. In de categorie van 25 jaar tot 54 jaar komen de arbeidsrollen scholier/student en gepensioneerde niet voor. Binnen de categorie 55-64 jarigen komt de rol van gepensioneerde nast die van werkende voor. De rol wan verzorger van jonge kinderen komt echter nauwelijks meer voor. In de categorie $64+$ is alleen de partnerrol als structurerende rol nog aanwezig.

Bij de vrouwen worden drie categorieën onderscheiden, de vrouwen onder de 25 , de vrouwen tussen 25 en 54 jaar en de vrouwen ouder dan 54 jaar. De rol van gepensioneerde komt bij de vrouwen nauwelijks voor en is dus niet onderzocht. In alle categorieën kan een onderscheicl gemaakt worden tussen huisvrouwen, werkenden en 
Tabel 4.3 .3

Frequentie vam positierollen naar leettijdscategorie bij de mannen.

\begin{tabular}{lrrrr} 
& \multicolumn{5}{c}{ Leeftijdscategorie } \\
& $\leq 24$ & $25-54$ & $55-64$ & $64+$ \\
\hline $\begin{array}{l}\text { Arbeidsrol } \\
\text { full-time werk }\end{array}$ & $40^{1}$ & $265^{1}$ & $32^{1}$ & 0 \\
school & $34^{1}$ & 5 & 0 & 0 \\
pensiloen & 0 & 1 & $19^{1}$ & 18 \\
anders & 13 & 42 & 22 & 2 \\
Partnerrol & & & & \\
partner & $12^{1}$ & $237^{1}$ & $65^{1}$ & $17^{1}$ \\
geen partner & 75 & 76 & 8 & 3 \\
Yerzorger & & & & \\
jonge kinderen & 3 & $128^{1}$ & 1 & 0 \\
geen jonge kinderen & 84 & 185 & 72 & 20 \\
Total & 87 & 313 & 73 & 25 \\
'gebruikt als dummy & & & & \\
\hline
\end{tabular}

anderen. In de jongste categorie komt ook de rol van scholier/student voldoende voor om te worden onderzocht. Bij de oudste categorie kan alleen het onderscheid tussen huisvrouwen en anderen worden gemaakt. Ook de rol van verzorger van jonge kinderen komt in deze categorie niet voor. De onderzochte positierollen verschillen dus per leeftijdscategorie. In tabellen 4.3.3 en 4.3.4 is alangegeven welke positierollen binnen de verschillende leeftijdscategorieen zijn onderzocht.

Daar de analyses binnen verschillende deelpopulaties (naar geslacht en leeftijd) worden uitgevoerd hebben de hypothesen ook op elk van deze deelpopulaties betrekking. Indien niet anders a angegeven betreffen de hypothese steeds elk van de categorieën van drinksituaties (droog, medium, nat). De hypothesen aangaande de duur van de expositie en de hoogte van de consumptie hebben daarnaast ook betrekking op het totaal van drinksituaties. 
Tabell 4.3 .4

Frequentie van positierollen naar leeftijd bil de wouwen.

Leeftijdscategorie

$\leq 24 \quad 25-54 \quad 55+$

\section{Arbeidsrol}

full-time werk

school

huisvrouw

anders

$\begin{array}{rrr}41^{1} & 69^{1} & 6 \\ 21^{1} & 2 & 0 \\ 13^{1} & 156^{1} & 64^{1} \\ 8 & 29 & 14\end{array}$

Partnerrol

partner

geen partner

Verzorger

jonge kinderen

$\begin{array}{rrr}9 & 112^{1} & 0 \\ 74 & 144 & 84\end{array}$

Totaal

83

256

84

gebruikt als dummy

\section{De logit-analyse}

In hoofdstuk 3 is voor elke drinksituatie afzonderlijk de kans op drankgebruik bepaald. Deze kans is berekend als het aantal drinkers binnen de betreffende situatie gedeeld doot her antal deelnemers aan die situatie. Ook per categorie van drinksituaties kan een dergelijke kans worden berekend. Deze betreft dan het aantal mensen dat in minstens een van de tot die categorie behorende situaties drinkt gedeeld door het totaal aantal mensen dat aan de tot die categorie behorende situaties deelneemt. Verschillen in drankgebruik tussen actoren die samenhangen met rollen kunnen onder andere tot uiting komen in verbanden tussen de proportie drinkers en deze rollen. Een analyse-methode waarmee dit soort verbanden kan worden onderzocht is de logit-analyse.

Binnen dleze analyse wordt gezocht naar een log-lineair model dat de verdeling van respondenten over de cellen van een multï-dimensionale kutstabel adequaat weergeeft. Voor elke warde (of combinatie van waarden) wan de onafhankelijke wariabele $(n)$ wordt een parameter berekend die beschrijft hoeveel hoger dan wel lager dan het gemiddelde de proportie drinkers in de categorie respondenten met die warde (of combinatie wan waarden) is (Norusis, 1984).

In de hier uitgevoerde analyses is uitgegaan van logit-modellen waarin onafhankelijkheid wordt verondersteld. Indien deze modellen de verdeling van respondenten over de cellen wan de kruistabel niet adequaat beschreven is onderzocht of het toevoegen van 2-weg interacties de 'fit' van het model significant verbeterde. In eerste instantie is onderzocht of de positierolvariabelen 
de voorspelling significunt verbeterden. Daarna is onderzocht of het toewoegen van de statusrolvariabelen het model nog kon verbeteren. Significante 2 -weg interacties moeten worden geinterpreteerd als samenhangen tussen de betreffende rollen (onathankelike variabeler) en de proportie drinkers. Op basis van de uitkomsten van de logit-analyses kan worden berekend hoe hoog de proportie drinkers per rol is. De analyses zijn per leeftijdscategorie voor mannen en vrouwen en voor elk van de categorieën drinksituaties (droog, medium, nat) afzonderlijk. verricht.

Indien het opnemen van 2 -weg interacties in het model niet tot een goede 'fit' zou leiden. zouden 3-weg interacties in het model zijn ingevoerd. In praktijk bleek dit laatste niet noodzakelijk te zijn.

\section{De multiple regressie analyse}

De analyses betreffende cle fitctoren die met de duur van de expositie en de hoogte van de consumptie samenhangen zijn verricht door middel van multiple regressie analyse.

De analyses zijn in twee fasen uitgewoerd. Eerst zijn de samenhangen tussen positierollen, statusrollen en de expositie an drinksituaties onderzocht. In deze eerste fase is de expositie de afhankelijke variabele. In de tweede fase zijn de relaties tussen rollen, expositie en consumptie onderzocht. De expositie is hierin een onaflankelijke variabele terwijl de consumptie de afhankelijke variabele is. Deze analyses zijn per categorie van drinksituaties afzonderlijk en voor alle drinksituaties samen uitgevoerd. Analyses ten aanzien van de expositie betreffen alleen deeinemers aan de betreffende categorie drinksituaties, de analyses betreffende de consumptie zijn uitgewoerd onder de drinkers per categorie van drinksituaties.

Overwegingen die geleid hebben tot de keuze van de multiple regressie analyse waren:

1. De grote flexibiliteit ten aunzien van de volgorde waarin de effecten van verschillende variabelen kan worden onderzocht, doordat de methode het toestaat om blokken variabelen na elkar in het regressie model in te voeren en te evalueren. Hierdoor kan het werklaringsmodel (zie 4.1 en 4.2 ) worden getoetst.

2. De informatie die door de uitkomsten van de regressie vergelijking wordt geboden. De regressiemethode geeft informatie over de absolute bijdrage van variabelen aan de voorspelling van de onafhankelijke èn informatie over de relatieve bijdrage van deze variabelen. Dit makt het mogelijk om de effecten van variabelen met verschillende meet-eenheden te vergelijken. Daarnaast is een van de uitkomsten het totale percentage verklatarde variantie. Dit maakt het mogelijk om de effecten van verschillende analyses te vergelijken.

Voor de volgende variabelen zijn dummy's gecreèerd: arbeidsrol, gezinsrol, verzorgersrol en religie. Voor elke variabele (type rollen) is een antal dummy's gecreeerd dat gelijk is aan het antal verschillende rollen min 1. Zo zijn voor religie drie dummy variabelen gecreeerd. Dit zijn 'Geen religie' 'Rooms katholiek' en 'Protestant'. De score op een dummy variabele is steeds 1 indien van toepassing en 0 indien niet van toepassing. Iemand die bij religie tot de categorie 'Anders' behoort scoort dus op alle drie de dummy-variabelen een 0 .

De analyses zijn in een arntal stappen uitgevoerd. Eerst zijn die positierolien die een significante $(p<.10)$ bijdrage aan de woorspelling van de expositie leveren ingevoerd. Het gekozen significantieniveau is hoger dan gebruikelijk. De keuze van dit hogere niveau komt 
voort uit de overweging dat de populaties per analyse niet al te groot zijn waardoor relaties op strengere niveaus minder snel significant zijn. In de tabellen met de resultaten zullen significantie-niveaus per effect weergegeven worden. Na de positierollen zijn de statusrollen sociale klasse en religie ingevaerd (indien ze significant met expositie samentangen). De mogelijkheid bestaat dat na invoering van statusrollen invbeden van positierollen alsnog verdwijnen. In gevallen dat variabelen na controle voor de andere variabelen in het model geen significante bijdrage meer zouden leveren zouden ze uit het model zijn verwijderd. Dit kwam overigens in praktijk niet voor.

Ook de relaties tussen rollen, expositie en consumptie zijn door middel van multiple regressie onderzocht. Als eerste is het effect van de expositie ingevoerd. Vervolgens zijn de effecten van positie- en statusrollen die na controle voor expositie nog een bijdrage aan de verklaring van de consumptie leveren in het model opgenomen. De relatie tussen expositie en consumptie vertegenwoordigt de structurele verklaringen van verschillen in consumptie. De gecontroleerde bijdragen van positie- en statusrollen vertegenwoordigen de bijdrage van de realisatie van drankgebruik ofwel de intensiteit van het drinkgedrag aan de verklaring van consumptie.

Uit de resultaten van de analyses zoals hierboven beschreven kan worden afgeleid in hoeverre er nog verschillen in consumptie van alcoholhoudende dranken blijven bestaan na controle op de expositie aan drinksituaties en in hoeverre positie- en statusrollen nog een bijdrage kunnen leveren aan de verklaring van deze verschillen. Verschillen in consumptie na controle voor expositie worden beschouwd als verschillen in de intensiteit van drinkgedrag. Een hogere intensiteit betekent niet per definitie ook een hogere consumptie. De consumptie is ook afhankelijk van de expositie.

\section{Overige analyses}

Naast de logit en de multiple regressie analyses zijn er nog een aantal aanvullende analyses verricht. Dit zijn enerzijds specifieke analyses van de expositie aan en consumptie in de afzonderlijke drinksituaties en anderzijds analyses van de relaties tussen rollen en drinkfrequentie in de dagboekweek.

\section{De afzonderlijke situaties}

Zoals aangegeven in paragraaf 4.3.1 zijn de aantallen deelnemers of drinkers onder de deelnemers, per drinksituatie afzonderlijk in veel gevallen erg klein. In ieder geval te klein om relaties tussen deelname aan dan wel consumptie binnen die situaties aan meer dan een onafhankelijke variabele tegelijkertijd te relateren. Toch zijn er analyses met betrekking tot de expositie aan (deelname en duur) en consumptie (al dan niet drinken en hoogte van de consumptie) per drinksituatie afzonderlijk verricht. Als onafhankelijke variabele is in deze analyses rolset gebruikt. Dit is een samengestelde variabele die de combinatie van positierollen die mensen vervullen weergeeft. De categorieën van deze variabele zijn weergegeven in tabellen 4.3 .6 en 4.3 .7 
Tabel 4.3 .5

Frequentie van combinaties van positierollen bij mannen.

\begin{tabular}{|c|c|c|c|}
\hline & & Zorg voor jonge kinderen & $\begin{array}{l}\text { en } \\
\text { wel }\end{array}$ \\
\hline \multirow{2}{*}{$\begin{array}{l}\text { Dull-time } \\
\text { werkend }\end{array}$} & geen partner & 85 & 11 \\
\hline & wel partiner & 135 & 106 \\
\hline $\begin{array}{l}\text { niet } \\
\text { full-time }\end{array}$ & geen partner & 65 & 1 \\
\hline werkend & well partner & 76 & 14 \\
\hline
\end{tabular}

Tabel 4.3.6

Frequentie van combinaties van positierollen bij vrouwen.

\begin{tabular}{|c|c|c|c|}
\hline & & \multicolumn{2}{|c|}{ Zorg voor jonge kinderen } \\
\hline & & niet & wel \\
\hline \multirow{2}{*}{$\begin{array}{l}\text { full time } \\
\text { werkend }\end{array}$} & geen partiner & 54 & 2 \\
\hline & wel partner & 47 & 13 \\
\hline \multirow{3}{*}{$\begin{array}{l}\text { niet } \\
\text { full-time } \\
\text { werkend }\end{array}$} & geen partuer & 4 & 7 \\
\hline & wel partner & 19 & 8 \\
\hline & geen partner & 33 & 18 \\
\hline huisvrouw & wel partner & 102 & 80 \\
\hline
\end{tabular}

Ook de rellaties tussen expositie en consumptie en statusrollen zijn per drinksituatie afzonderlijk onderzocht. Er zijn echter geen analyses verricht waarin meer dan een onafhankelijke variabele werd gebruikt.

De resultaten van deze analyses zijn weergegeven in de Bijlagen $4.1 \mathrm{en}$ 4.2. In de bespreking van de resultaten zullen ze zo nu en dan ter illustratie worden gebruikt. 


\section{Consumptie-niveau en rollen}

Categorieën van respondenten die zonder twijfel verschillen met betrekking tot de intensiteit van hun drankgebruik zijn de zware, matige en lichte drinkers zoals beschreven in hoofdstuk 3 . Als aanvullende analyse bij het voorafgaande is onderzocht of het aantal lichte, matige of zware drinkers samenhangt met structurerende positierollen. De verwachting is dat het percentage zware drinkers het hoogst zal zijn indien structurerende positierollen ontbreken. Het laagste aantal zware (en hoogste aantal lichte) drinkers mag worden verwacht in de categorie met een full-time baan, een partner en de zorg voor jonge kinderen.

Zowel voor de combinatie van positierollen (rolset) als voor elk van de positie- en statusrollen afzonderlijk is onderzocht of ze samenhangen met het percentage zware, matige of lichte drinkers en ook met het percentage van de populatie dat tijdens de dagboekweek niet gedronken heeft. Deze analyses zijn door middel van $X^{2}$-toetsen uitgevoerd.

\subsection{Overzicht van analyses en hypothesen}

In schema 4.4.1 wordt kort een overzicht wan alle hypothesen en bijhorende analyses gepresenteerd. De richting van veronderstelde relaties is aangegeven en ook de populatie waarop de hypothese betrekking heeft wordt vermeld. De resultaten van de analyses betreffende rollen en expositie en relaties tussen expositie en consumptie worden gepresenteerd in hoofdstuk 5. De resultaten van de analyses aangaande relaties tussen rollen en intensiteit van drinkgedrag worden in hoofdstuk 6 weergegeven. 


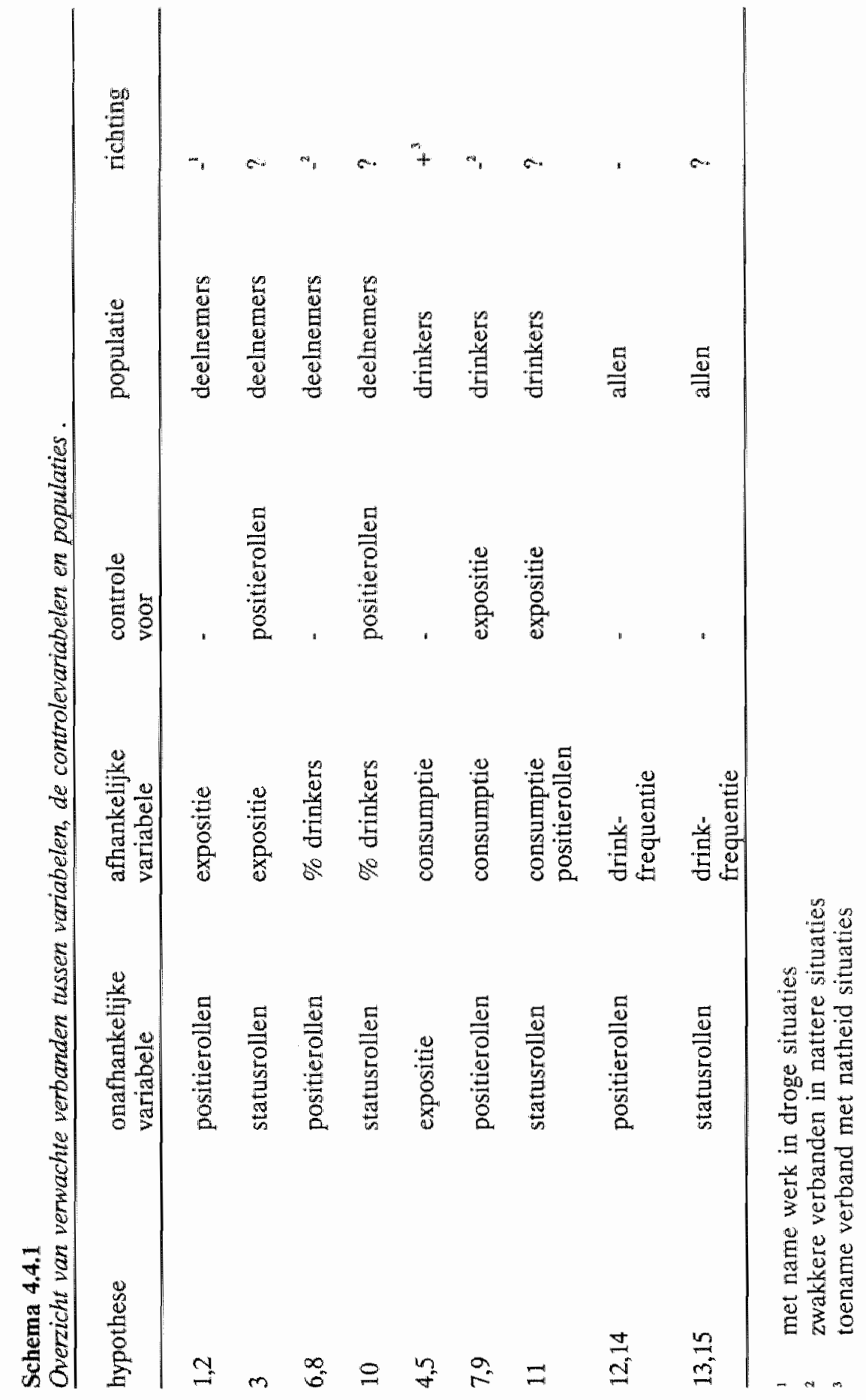




\section{Hoofdstuk 5 Rollen en expositie, expositie en
consumptie}

In hoofdstuk 4 is de totstandkoming van drinkgedrag verdeeld in twee fasen, de expositie ann drinksituaties en de realisatie van drinkgedrag. In dit hoofdstuk worden aan de hand van de hypothesen geformuleerd in paragraaf 4.3.3, de resultaten van de analyses betreffende samenhangen tussen rollen en expositie en samenhangen tussen expositie aan drinksituaties en consumptie in drinksituaties beschreven. Per categorie van drinksituaties (droog, medium, nat) en voor alle drinksituaties tezamen zijn analyses verricht binnen verschillende categorieën van respondenten gedefinieerd naar leeftijd en geslacht. In paragraaf 5.1 zullen de resultaten van de multiple regressie analyses met positie- en statusrollen als onafhankelijke en expositie als afhankelijke variabele besproken worden. In paragraaf 5.2 wordt de relatie tussen expositie en consumptie behandeld.

\subsection{Rollen en expositie}

Ten aanzien van relaties tussen rollen en expositie aan drinksituaties is verondersteld diat mensen met structurerende positierollen minder tijd in drinksituaties doorbrengen dan mensen zonder structurerende positierollen (hypothese 1). Verder is verondersteld dat de verschillen in tijd doorgebracht in drinksituaties tussen werkenden en niet-werkenden het grootst zijn in droge situaties (hypothese 2). Tenslotte is verondersteld dat statusrollen ma controle voor positierollen, een deel van de variantie in expositie aan drinksituaties kunnen verklaren (hypothese 3).

\section{De mannen}

De resultaten van de multiple regressie analyses per leeftijdscategorie in de mannelijke populatie zijn weergegeven in tabel 5.1.1. De positierollen die voldoende voorkomen om als variabele in de analyses te worden gebruikt verschillen per leeftijdscategorie. Bij de jonge mannen komt naast de rol van werkende of werkloze ook de rol van scholier/student voor. Bij mannen tussen 55 en 64 jaar komt naast de rollen van werkende en niet werkende, ook de rol van gepensioneerde voor en komt de rol van verzorger van jonge kinderen niet voor. In de 
wategorie ouder dan 64 jaar komt alleen de structurerende rol van partner voor. Binnen de categorje matrinen tussen 25 en 54 jaar is nast religie en sociale klasse ook de statusrolleeftijd als variabele gebruikt.

Werk blikt significant negatief samen te hangen met dexpositie aan drinksituaties. Werkenden besteden minder tijd in droge drinksituaties dan werklozen, scholieren/studenten ( $\leq 24$ jaar) of gepensioneerden ( 55.64 jaar) van gelijke leeftijd. Werkenden tussen 25 en 54 jaar besteden eveneens minder tijd dan niet werkender in medium drinksituaties. Werkenden tussen 25 en 54 jaar en die tussen 55 en 64 jaar besteden ook in totaal minder tijd in drinksituaties dan hun niet werkende leeftijsgenoten. Scholieren/studenten bliken ten opzichte van andere jonge mannen minder tijd te besteden in medium en natte situaties.

De rol van pattner hangt alleen bij mannen tussen 25 en 54 jaar significant samen met de expositie a an drinksituaties. Mannen met partner besteden meer tijd in medium situaties, maar minder in natte situaties dan mannen zonder partner. In de totale expositie blijkt geen effect van de partnerrol.

De rol van verzorger/opvoeder komt bij de mannen alleen in de leeftijdscategorie tussen 25 en 54 jar voldoende voor om als variabele te worden gebrukt. In geen der categorieèn van drinksitwaties (droog, medium, nat) blijkt een significant effect van deze rol op de expositie. De totale expositie aan drinksituaties hangt echter significant negatief samen met de rol van verzorger/opvoeder van jonge kinderen.

In de multiplle regressie analyses zijin de effecten van statusrollen op de expositie gecontroleerd voor significante effecten van positierollen op de expositie.

Bij de jongere mannen blijken geen significante effecten van statusrollen op de expositie aan drinksituaties. Bij de mannen tussen 25 en 54 jaar blijkt een negatief effect van sociale klasse op de tijd besteed in droge drinksituaties en een positief effect op de tijd doorgebracht in natte situaties.

Religie blijkt in alle leeftijdscategorieën boven 25 jar significante effecten op de expositie aan drinksituaties te hebben. Geen religie hangt positief samen met de expositie aan natte situaties (25-54 jaar), Rooms-Katholiscisme hangt positief samen met de expositie an medium situaties en de totale expositie (55-64 jaar). Bij de mannen bowen 65 jaar is religie de enige factor die significant met expositie aan drinksituaties samenhangt. Rooms-Katholieke ouderen besteden meer tijd in natte situaties dan ouderen met een andere of zonder religieuze overtuiging. 


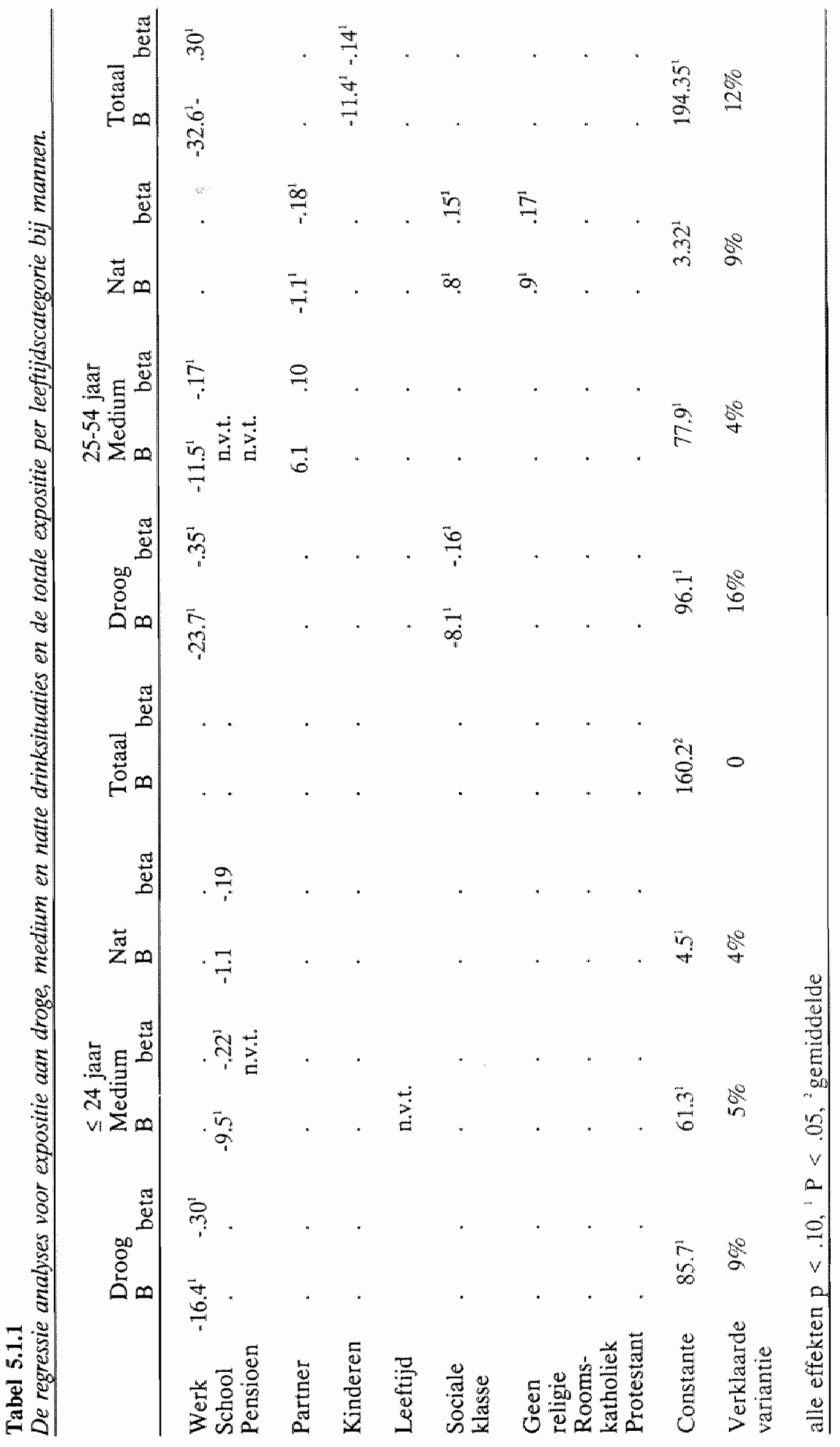




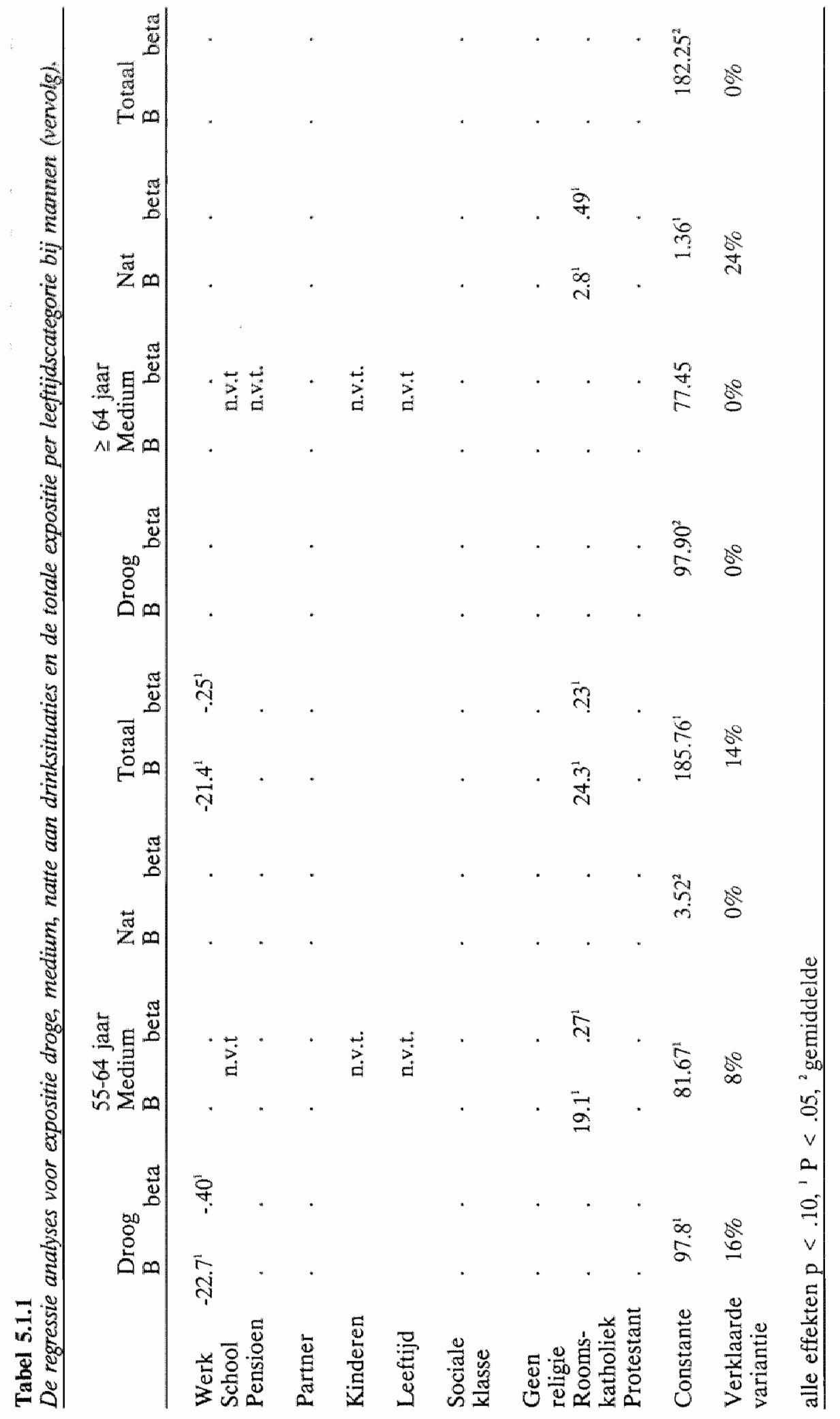




\section{De vrouwen}

De resultaten van de multiple regressie analyses per leeftijdscategorie in de vrouwelijke populatie zijn weergegeven in tabel 5.1.2. Bij vrouwen komt de rol van huisvrouw natast die van werkende, scholier/student of ander"s voor. Bij vrouwen ouder dan 54 jaar is het de anige structurerende positierol die voorkomt. De positierol van scholier/student kom alleen bij vnouwen jonger dan 25 jaar, voor.

Bij de jonge vrouwen zijn geen significante verbanden gevonden tussen de rollen scholier/student, huisvrouw, werkende of anders en de expositie aan drinksituaties. Bij vrowwen tussen 25 en 54 jaar blijkt werk negatief samen te hangen met de expositie aan droge drinksituaties. Ook de totale expositie aan drinksituaties hangt negatief samen met de rol van werkende. Vrouwen ouder dan 54 jaar, die zich zelf als huiswrouw beschouwen besteden meer tijd in medium drinksituaties dan andere vrouwen van die leeftijd.

De rol van partner hangt negatief samen met de expositie aan medium situaties van vrouwen ouder dan 54 jaar. Dit komt ook in de totale expositie aan drinksituatie naar voren.

De rol van verzorgster/opvoedster van jonge kinderen blijkt bij jonge vrouwen $(\leq 24$ jaat) de tijjd doorgebracht in droge drinksituaties positief te beinvloeden. Bij vrouwen tussen 25 en 54 jaar beperkt deze rol de tijd besteed in medium situaties. Ook de totale expositie aan drinksituaties van wrouwen tussen 25 en 54 jaar met de zorg voor jonge kinderen, is lager dan die van hun leeftijdsgenoten zonder de zorg voor jonge kinderen.

De statusrol sociale klasse hangt negatief samen met de tijd doorgebracht in drinksituaties. Jonge vrouwen uït de lagere klassen besteden meer tijd in droge en medium drinksituaties dan hun leeftijdsgenoten wit de hogere klassen. Dit blijkt ook in de totale expositie aar drinksituaties. Vrouwen tussen 25 en 54 jaar uit de lagere klassen brengen meer tijd door in medium drinksituaties.

Significante samenhangen tussen religie en expositie aan drinksituaties blijken uit negatieve verbanden tussen protestantse gezindheid en de tijd die jonge vrouwen in natte situaties besteden en de tijd die vrouwen tussen 25 en 54 jaar in medium situaties besteden. Protestante vrouwen tussen 25 en 54 jar besteden ook in totaal minder tijd in drinksituaties dan vrouwen zonder of met een andere religieuze overtuiging.

Net als bij de mannen zijn ook bij de vrouwen alleen in de categorie tussen 25 en 54 jaar effecten van leeftijd onderzocht. Binnen deze leeftijdscategorie blijkt dat de ouderen meer tijd doorbrengen in droge drinksituaties maar minder in medium drinksituaties. Leeftijd hangt niet significant samen met de totale expositie an drinksituaties van vrouwen tussen 25 en 54 juar. 


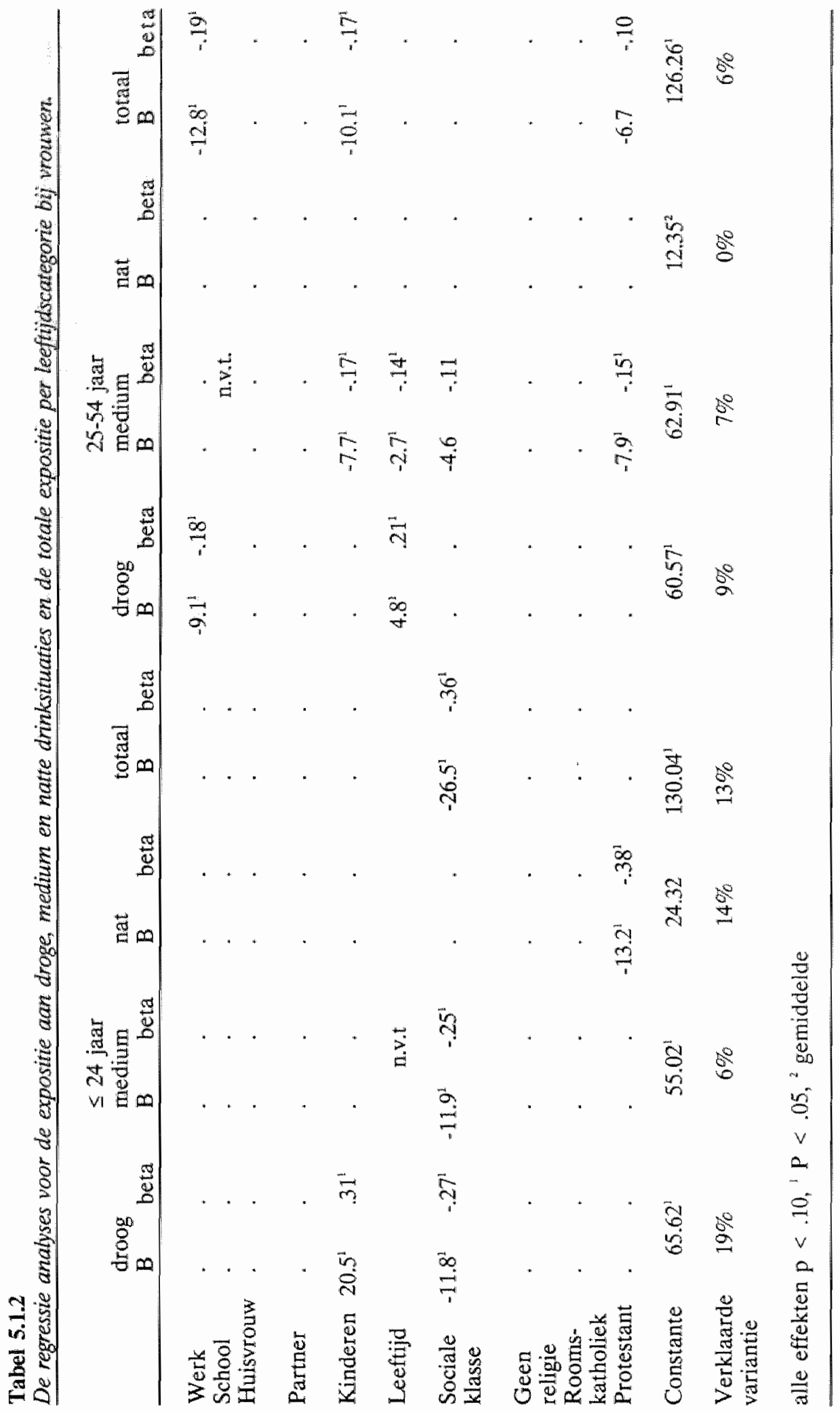




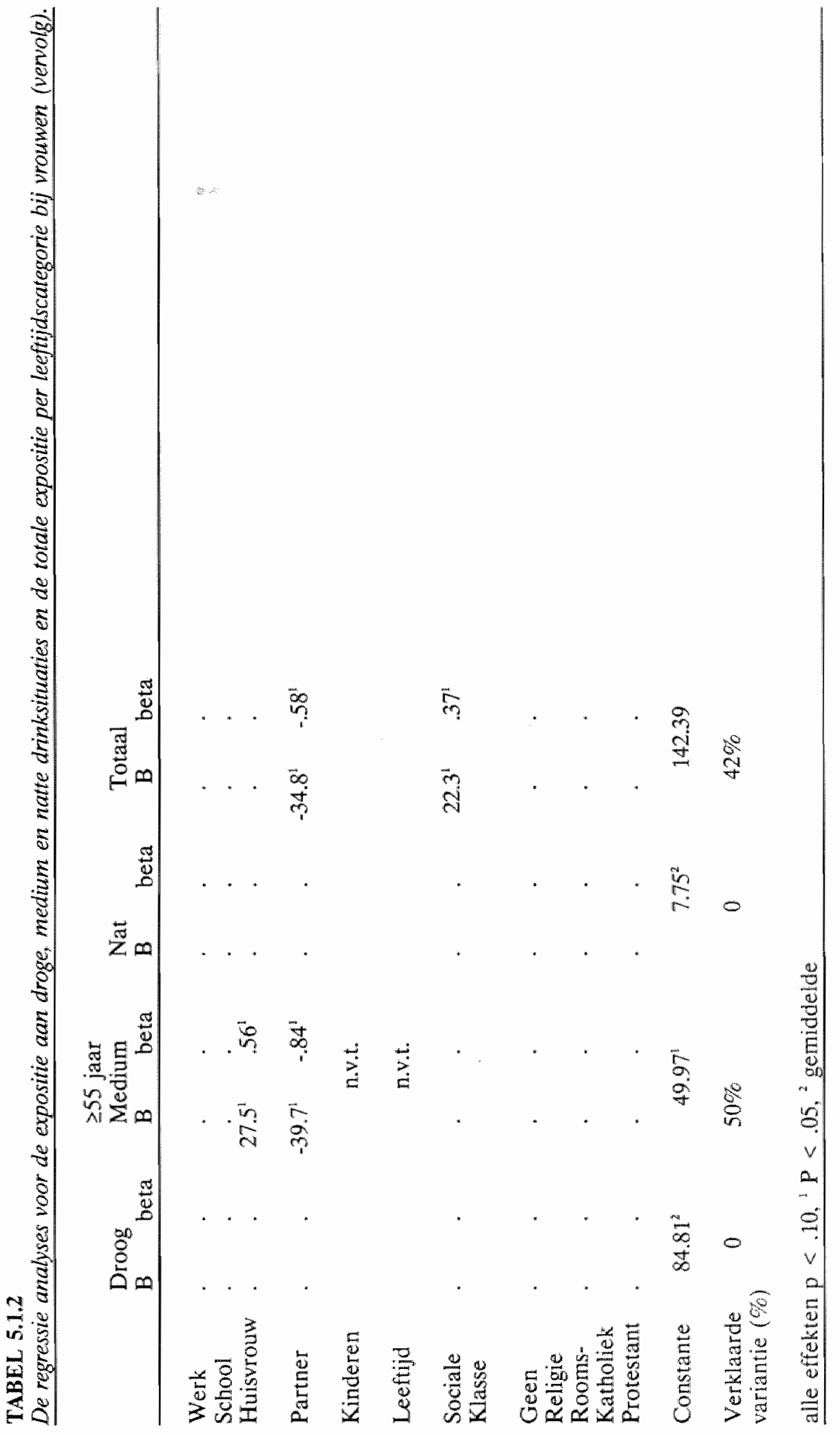




\section{Coniclusies, rollen en expositie}

Ten aanzien van relaties tussen rollen en de expositie atan drinksituaties is een drietal hypothesen geformuleerd. De resultaten van de regressie analyses tonen dat de algemene veronderstelling dat mensen met structurerende positierollen minder tijd doorbrengen in drinksituaties dan mensen zonder zulke rollen (hypothese 1) in een aantal gevallen verworpen moet worden. Zo blijkt dat mannen tussen 25 en 54 jaar met een partner meer tijd in medium drinksituaties doorbrengen dan hun leeftijdsgenoten zonder partner. Jonge vrouwen met de zorg voor jonge kinderen besteden meer tijd in droge drinksituaties dan de jonge vrouwen zonder de rol wan verzorgster/opvoedster. De meeste verbanden tussen positierollen en expositie zijn echter in overeenstemming met hypothese 1 . De rol van werkende hangt negatief samen met de expositie aan droge situaties van jonge mannen, mannen tussen 25 en 54 jaar, mannen tussen 55 en 64 jaar en vrouwen tussen 25 en 54 jaar. Ook negatieve verbanden tussen werk en expositie aan medium situaties (mannen, $25-54$ jaar), partner en de expositie aan medium (vrouwen $\geq 55$ jaar) en natte situaties (mannen 25-54 jaar) en zorg voor jonge kinderen en totale expositie (mannen 25-54 jaar, vrouwen 25-54 jaar) en expositie aan medium situaties (vrouwen $25-54$ jaar) sternmen met hypothese 1 overeen.

De rollen van scholier/student en die van werkende sluiten elkaar uit. Negatieve verbanden van scholier/student met de expositie alan medium en natte situaties (jonge mannen) betekenen dan ook positieve verbanden tussen werk en deze expositie. Uit de tegengestelde effecten in droge situaties enerzijds en medium en natte situaties anderzijds kan wellicht worden verklaard waarom er geen verbanden tussen scholier/student of werk en de totale expositie blijken. Binnen de categorie der jonge mannen besteden werkenden meer tijd in medium en natte situaties dan scholieren/studenten of anderen. Zowel de rol van werkende als die van scholier/student zijn alls structurerende rollen beschouwd. De positieve verbanden tussen werk en expositie bij jonge mannen zijin daarom niet in tegenspraak met hypothese 1.

De rol van partner hangt eveneens positief samen met de expositie aan medium situaties (mannen tussen 25 en 54 jaar). Mogelijk bevinden jongere werkenden (in vergelijking tot scholieren /studenten) en degenen met partner (ten opzichte wan degenen zonder partner) zich in de gezinsfase. Deze levensfase lijkt met name wat betreft de expositie aan medium drinksituaties (bij mannen) de mogelijkheid om te drinken te bevorderen. Ook de grotere blootstelling van jonge vrouwen met de zorg voor jonge kinderen kan op deze wijze worden geinterpreteerd.

Behalve bij mannen tussen 25 en 54 jaar werden alleen in droge situaties verbanden tussen werk en expositie gevonden. Bij mannen tussen 25 en 54 jaar is het negatieve verband tussen werk en expositie aan droge situaties sterker dan dat tussen werk en de expositie aan medium situaties. Deze resultaten zijn in overeenstemming met de veronderstelling dat verbanden tussem (niet.) werken en expositie het sterkst zijn in droge situaties (hypothese 2).

Verbanden tussen religie en expositie zijn zeer eenduidig. Geen religie (mannen 25-54, natte situaties) en rooms katholicisme (mannen $25-54$ medium situaties; mannen $\geq 65$, natte situaties) hangen positief, protestantisme (wrouwen 25-54, medium situaties; vrouwen $\leq 24$ jaar, natte situaties) negatief met expositie samen.

De relaties tussen sociale klasse en expositie zijn minder eenduidig. Deze statusrol hangt negatief samen met de expositie aan droge situaties van mannen tussen 25 en 54 jaar. Bij dezelfde categorie mannen hangt sociale klasse positief samen met de expositie aan natte situaties. Bij de vrouwen blijken negatieve verbanden in droge situaties ( $\leq 24$ jaar), in medium situaties (25-54 jaar) en in totaal (25-54 jaar). Vrouwen ouder dan 54 jaar uit de hogere sociale. 
klassen besteden in totaal echter mér tijd in drinksituaties dan hun leeftijdsgenoten wit da lagere klassen.

De totale expositie is de som van de expositie and droge, medum en natre situaties. In een antall gevallen doen de relaties tussen rollen en de expositie aan droge, medium of natte situaties zich ook voor mer betrekking tot de totale expositie. In sommige gewallen bliken significante samenhangen tussen rollen en de totale expositie die in geen der afzonderlijke categorieën van drinksituaties blijken (mannen $25-54$ jatr, zorg voor kinderen; vrouwen 25-54 jaar, partner). Ook het tegenovergestelde komt voor: in een categorie van drinksituaties wordt een significant verband gevonden dat in de totale expositie niet tot uiting komt. Naast de tegengestelde effecten van werk en scholier/student bij jongere mannen zijn or nog twee gevallen waarin de effecten van rollen op de expositie aan verschillende categorieën van drinksituaties elkaar lijken op te heffen. Zo hangt de rol wan partner positief samen met de expositie aan medium situaties, maar negatief met die aan natte situaties (mannen 25-54 jaar); in de totale expositie aan drinksituaties blijkt geen samenhang Sociale klasse hangt positief samen met de expositie aan droge situaties en negatief met die aan natte situaties (mannen 25 . 54 jarar). Ook hier blijkt in de totale expositie geen effect.

\subsection{Expositie en consumptie}

De in paragraaf 5.1 gepresenteerde analyses over relaties tussen positie- en statusrollen en de expositie aan drinksituaties, zijn verricht vanuit de veronderstelling dat er een verband is tussen expositie aan drinksituaties en de consumptie in die situaties. Hypothese 4 stelt dat natrmate men meer tijd doorbrengt in drunksituaties men in die situaties ook meer drinkt. Verder is verondersteld dat de relatie tussen de tijd doorgebracht in drinksituaties en de consumptie in die situaties in sterkte toeneemt met de natheid van de situaties (hypothese 5).

Relaties tussen expositie en consumptie zijn onderzocht door middel van multiple regressie analyses met expositie en rollen als onathankelijke variabelen. Expositie is in die analyses als eerste variabele ingevoerd. De volledige resultaten van deze regnessie analyses worden beschreven in hoofdstuk 6 . In deze paragraaf zullen alleen de verbanden tussen expositie en consumptie worden samengevat.

\section{De mannen}

In tabel 5.2.1 worden de resultaten van de analyses betreffende de relaties tussen expositie en consumptie in de afzondarlijke categorieën van drinksituaties per leeftijoscategorio van de mannelijke populatie gepresenteerd.

In droge situaties blijken expositie en consumptie alleen bij mannen tussen 25 en 54 jaar significant met elkaar samen te hangen. Bimnen de groep ouder dan 64 jaar hangen wxpsitie en consumptie in geen der categorieen van drinksituaties significant met elkaar samen. De geconstateerde verbanden tussen expositie en consumptie zijn het sterkst in natte drinksituaties. Ook tussen de totale expositie aan drinksituaties en de totale consumptie in die sifuaties blijken redelijk sterke positieve verbanden te bestaan. 
Tabel 5.2 .1

Verbanden tussen expositie aan en consumptie in categorieën van drinksituaties (droog. medium, nat en totaal) naar leettijo bij de mannen, wittreksel regressie analyses.

categorie van drinksituaties

\begin{tabular}{|c|c|c|c|c|c|c|c|c|}
\hline & \multicolumn{2}{|c|}{ Droog } & \multicolumn{2}{|c|}{ Medium } & \multicolumn{2}{|c|}{ Nat } & \multicolumn{2}{|c|}{ Totaal } \\
\hline & B & beta & B & beta & B & beta & $\mathrm{B}$ & beta \\
\hline$\leq 24$ jaar & - & $=$ & .01 & .24 & .55 & .73 & .01 & .30 \\
\hline 25-54 jaar & .02 & .39 & .11 & .36 & .57 & .75 & .02 & .43 \\
\hline 55-64 jaatr & - & - & .02 & .40 & .41 & .69 & .01 & .27 \\
\hline$\geq 65$ jaar & - & . & . & - & * & - & - & - \\
\hline
\end{tabular}

\section{De vrouwen}

In tabel 5.2.2 worden de resultaten van de analyses betreffende de relaties tussen expositie en consumptie in de afzonderlijke categorieèn van drinksituaties per leeftijdscategorie van de vrouwelijke populatie gepresenteerd.

\section{Tabel 5.2.2}

Verbanden tussen expositie aan en consumptie in categorieën van drinksituaties (droog, medium, nat en totaal) naar leeftijd bij de mannen, uittreksel regressie-analyses.

\begin{tabular}{|c|c|c|c|c|c|c|c|c|}
\hline & \multicolumn{6}{|c|}{ Categorie van drinksituaties } & & \\
\hline & \multicolumn{2}{|c|}{ Droog } & \multicolumn{2}{|c|}{ Medium } & \multicolumn{2}{|c|}{ Nat } & \multicolumn{2}{|c|}{ Totaal } \\
\hline & B & beta & B. & beta & B & beta & $B$ & beta \\
\hline$\leq 24$ jatr & .02 & .54 & .02 & .45 & * & - & .01 & .28 \\
\hline $25-54$ jaar & .01 & .24 & .02 & 43 & .04 & .49 & .01 & .28 \\
\hline$\geq 55$ jaar & & $.40^{1}$ & & $.49^{3}$ & - & - & & $.26^{1}$ \\
\hline "pearsons" & & & & & & & & \\
\hline
\end{tabular}

Bij de oudere vrouwen blijken geen significante verbanden tussen expositie aan natte drinksituaties en consumptie in die situaties. Ook bij vrouwen jonger dan 24 jaar kan geen verband tussen de tijd doorgebracht in natte situaties en de consumptie in die situaties worden geconstateerd. Bij de jonge vrouwen is het verband tussen expositie en consumptie in droge 
situaties sterker dan in medium situaties. Bij vrouwen tussen 25 en 54 jaar neemt de sterkte van de relatie tussen expositie en consumptie toe met de natheid wan de drinksituaties. $\mathrm{B}$ ij de oudere vrouwen is het verband tussen expositie en consumptie in medium situaties sterker dan in droge situaties. Binnen alle leeftijdscategorieän hangen ook de totale expositie anan drinksituaties en de totale consumptie binnen drinksituaties redelik sterk positief samen.

\section{Conclusies, expositie en consumptie}

Centraal in het model dat de totstandkoming van drinkgedrag beschrijt staat de relatie tussen expositie aan drinksituaties en de consumptie in die situaties.

Hypothese 4 veronderstelt positieve verbanden tussen expositie en consumptie. Er zijn inderdaad alleen positieve verbanden tussen expositie en consumptie gevonden. Verder is gebleken dat, behalve bij de jonge vrouwen, de sterkte van de verbanden tussen expositie en consumptie toeneemt met de natheid van de situaties. Hypothese 5 wordt hierdoor ondersteunt. Niet in alle gevallen worden significante relaties tussen expositie en consumptie gevonden. De correlaties tussen expositie en consumptie zijn berekend woor degenen die aan een categorue van drinksituaties hebben deelgenomen èn binnen deze categorie hebben gedronken. In een aantal gevallen is het aantal drinkers zo klein dat dit het ontbreken van significante relaties kan verklaren. Dit is van toepassing op de natte situaties bij de oudere vrouwen (zelfs te weinig deelnemers) en alle categorieèn van drinksituaties bij de oudere mannen. Dat er in de droge situaties (jongere mannen, mannen tussen 55 en 64 jaar en vrowwen boven 55 jaar) geen correllaties worden gevonden kan niet door te kleine aantallen worden verklaard. Deze resultaten zijn in overeenstemming met hypothese 5, er zijn zwakkere verbanden tussen expositie en consumptie in droge situaties. Alcoholgebrük lijkt voor deze categorieën van de populatie in de droge situaties niet prominent als gedragsalternatief aanwezig te zijn. De tijd die in dergelijke situaties wordt doorbrengt is nauwelijks van invloed op de consumptie in die situaties. Bij mannen en vrouwen tussen 25 en 54 jar worden in droge situaties redelijk sterke correlaties tussen expositie en consumptie gevonden (multiple R respectievelijk .39 en .24). Onder mannen en vrouwen van middelbare leeftijd komen relatief de meeste zware drinkers voor. Wellicht dat de betekenis van de drinksituatie voor hen anders is, met andere woorden dat drankgebruik als gedragsalternatief ook in droge situaties prominent aanwezig is.

Bij jongere vrouwen blijkt een sterke samenhang tussen expositie aan droge situaties en consumptie in die situaties (multiple $r=54$ ). Tevens blijkt de sterkte van het verband tussen expositie en consumptie bij de jonge vrouwen af te nemen met de natheid van de situaties. Dit laatste is in tegenspraak met hypothese 5. 


\subsection{Algemene conclusies}

Al met al blijken uit de resultaten in dit hoofdstuk duidelijke positieve verbanden tussen de tijd die men in drinksituaties doorbrengt en de consumptie in die situaties. Verder blijkt dat de sterkte van deze verbanden toeneemt met de natheid van de drinksituaties.

De redenering achter de zogenaamde 'leisure-time" hypothesen (Winton et al., 1987) wordt door deze resultaten bevestigd. Hoe meer tijd er in drinksituaties wordt besteed hoe hoger de consumptie. De 'leisure-time' hypothesen veronderstellen verder dat het ontbreken van structurerende rollen (met name de rol van werkende) via de tijdsbesteding tot een hogere consumptie zou leiden. De veronderstelling dat het ontbreken van structurerende positierollen tot een grotere blootstelling aan drinksituaties zou leiden gaat echter niet altijd op. In een aanta] gevallen blijken structurerende positierollen tot een hogere expositie aan drinksituaties te leulden. Met name rollen die samengaan met de gezinsfase lijken de tijd doorgebracht in medium situaties (mannen) en droge situaties (wrouwen) te bevorderen.

Een vraag die op grond van het hier gebruikte materiaal niet beantwoord kan worden is in hoeverre de tijd doorgebracht in drinksituaties als een toevallig resultaat van de structuur van het dagelijks leven dan wel als thet gevolg van bewuste keuzes mag worden beschouwd. De leisure-time hypothesen gaan uit wan het eerste. Met name de effecten van positierollen op de tijd besteed in drinksituaties kunnen in dit licht worden gezien. Het is echter niet ondenkbaar dat men situaties opzoekt om te drinken. Indien dit het geval zou zijn zou zich dat met name in de 'nattere' situaties voor doen. In dergelijke situaties is drankgebruik het prominenst aanwezig.

Om deze vraag te kunnen beantwoorden zouden respondenten moeten aangeven welke plaats drankgebruik voor hen in een situatie heeft. De natheid van situaties is een objectief gegeven, gebaseerd op empirische feiten. Er is verondersteld dat de kans op drinkgedrag samenhangt met c.q. voortkomt uit de beoordeling van de gepastheid wan drinkgedrag in situaties. Dat neemt niet weg dat er verschillen tussen individuen kunnen bestaan in de wijze waarop ze situaties interpreteren. Het is zelfs mogelijk dat mensen een situaties de ene keer anders interpreteren dan de andere keer. De sociale betekenis die mensen aan situaties verlenen hangt waarschijnlijk duidelijker met het drinkgedrag in die situaties samen dan de objectieve kenmerken van die situaties. Het zou interessant kunnen zijn om te onderzoeken welke betekenissen van situaties met drinkgedrag samenhangen en hoe dit varieert naar objectieve kenmerken van die situaties en de rollen die mensen vervullen. Aldus kan ook nagegaan worden in hoeverre mensen situaties opzoeken omdat erin gedronken kan worden.

Gezien de sterke relaties tussen expositie aan drinksituaties en consumptie in die situaties mag worden geconcludeerd dat het zinvol is om factoren die met de expositie aan drinksituaties samenhangen te onderzoeken en deze te onderscheiden van factoren die het drinkgedrag bij deelname aan die situaties beinwloeden. Verder tonen de resultaten van de analyses in dit hoofdstuk dat het zeker zinvol is om een onderscheid tussen verschillende categorieën van drinksituaties te maken. In het slothoofdstuk van dit proefschrift zal worden ingegaan op de keuze van kenmerken op op basis watarvan categorieën van situaties kunnen worden samengesteld. 


\section{Hoofdstuk 6 \\ Rollen en consumptie}

In dit hoofdstuk worden resultaten van de analyses betreffende de tweede fase in de totstandkoming van alcoholgebruik, de realisatie van drinkgedrag, beschreven. Bij deelnemers aan categorieën van drinksitwaties is onderzocht hoe rollen samenhangen met de kans om te drinken in die drinksituaties. De relaties tussen rollen en het al dan niet drinken in categorieèn van drinksituaties worden beschreven in paragraaf 6.1. Ook samenhangen van rollen met de intensiteit van het drinkgedrag van degenen die binnen categorieën van drinksituaties drinken zijn onderzocht. In paragraaf 6.2 worden de relaties tussen rollen en de voor expositie gecontroleerde, consumptie in categorieën van drinksituaties beschreven. Paragraaf 6.3 betreft relaties tussen rollen en het totale consumptieniveau tijdens de dagboekweek.

\subsection{Rollen en al dan niet drinken}

Ten aanzien van relaties tussen rollen en al dan niet drinken bij deelname alan drinksituaties. is verondersteld dat het percentage drinkende deelnemers bij mensen zonder structurerende rollen hoger zal zijn dan bij mensen met structurerende rollen (hypothese 6). Tevens is de verwachting uitgesproken dat de relaties tussen structurerende positierollen en het percentage drinkende deelnemers minder sterk zullen zijn in nattere situaties (hypothese 8 ). Hypothese 10 stelt dat na controle voor positierollen, ook statusrollen nog bijdragen aan de verklaring wan het al dan niet drinken van deelnemers aan categorieën van drinksituaties.

In de werschillende deelpopulaties gedefinieerd naar leeftijd en geslacht, zijn deze hypothesen onderzocht door middel van logit-analyses van het al dan niet drinken per categorie van drinksituaties. 


\section{De mannen}

In tabel 6.1.1 wordt een overzicht gepresenteerd van de resultaten van de logit analyses per leeftijdscategorie bij de mannen.

De odds ratio's in de tabel zipn het quotient van het aantal deelnemers dat niet drinkt en het aantal deelnemers dat wel drinkt. Een relatief groot aantal drinkers resulteert in een lage odds ratio.

Er zijn enkele significante verbanden tussen positierollen en het percentage drinkende deelnemers. Onder de werkende jongeren zijn er relatief veel meer drinkers dan onder de scholieren/studenten of anderen. Bij de mannen onder de 25 jaar zijn er voor elke drinkende dealnemer aan de droge situaties 2 die niet drinken. Deze ratio is onder de werkende jongeren 2:3 maar onder de scholieren/studenten en de anderen 1:4. Met andere woorden de arbeidsrol. hangt significant samen met het al dan niet drinken in droge situaties bij de jonge mannen. Bij mannen tussen 25 en 54 jaar zijn er zowel in droge als in medium en natte situaties meer drinkende dan niet drinkende deelnemers. In deze categorie blijkt de variabele partner noodzakelijk te zijn om een logit-model

\section{Tabel 6.1.1}

Signifikante odds ratios (niet drinken:wel drinken) in droge, medium en natte situaties bij mannen in verschillende leeftijoscategorieën.

\begin{tabular}{|c|c|c|c|c|c|c|}
\hline & \multicolumn{3}{|c|}{$\leq 24$ jaar } & \multicolumn{3}{|c|}{ 25-54 jaar } \\
\hline & Droog & Medium & Nat & Droog & Medium & Nat \\
\hline Allen & 1.93 & 1.12 & .58 & .80 & .37 & .30 \\
\hline Werk & 1.67 & - & - & - & - & - \\
\hline School & 3.78 & - & - & & n.v.t. & \\
\hline Pensioen & & n.v.th & & & n.v.t. & \\
\hline Anders & 3.25 & - & - & - & - & - \\
\hline Geen Partner & - & - & - & . & .50 & - \\
\hline Wel Partner & - & . & - & - & .26 & - \\
\hline Gean Kinderen & $=$ & - & - & - & - & - \\
\hline Wal Kinderen & - & - & - & - & - & - \\
\hline Lagere Kasse & - & - & - & - & - & .39 \\
\hline Hogere Klasse & - & - & - & - & - & .23 \\
\hline Geen Religie & - & - & - & .94 & . & - \\
\hline Rooms Katholiek & $=$ & 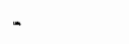 & - & .68 & - & - \\
\hline Protestant & - & - & - & 1.32 & . & - \\
\hline Anders & - & - & . & 1.19 & - & - \\
\hline
\end{tabular}


Tabel 6.1.1

Vervolg

\begin{tabular}{|c|c|c|c|}
\hline & Droog & $\begin{array}{l}55-64 \text { jaar } \\
\text { Medium }\end{array}$ & Nat \\
\hline Allen & $\mathbb{1 . 3 5}$ & .59 & .93 \\
\hline Werk & & n.v.t. & \\
\hline School & & n.v.t. & \\
\hline Pensioen & & n.v.t. & \\
\hline Anders & & n.v.t & \\
\hline Geen Partner & - & - & $=$ \\
\hline Wel Partner & - & - & - \\
\hline Geen Kinderen & & n.v.t. & \\
\hline Wel Kinderen & & n.v.t. & \\
\hline Lagere Klasse & - & - & 1.62 \\
\hline Hogere Klasse & - & - & .54 \\
\hline Geen Religie & - & - & - \\
\hline Rooms Katholiek & - & $=$ & - \\
\hline Protestant & - & - & - \\
\hline Anders & - & - & - \\
\hline
\end{tabular}

op te kunnen stellen dat een adequate beschrijving van de data met betrekking tot het al dan niet drinken in medium situaties geeft. Onder de mannen zonder partner is de verhouding drinken:niet drinken in medium situaties $2: 1$ onder de mannen met partner is deze 4:1. Deze verhouding komt bijwoorbeeld tot witing in het percentage mannen met partner dat drinkt bij het televisiekijken. Dit percentage is 2 tot 3 maal zo hoog als dat van de mannen zonder partner. In nog extremere mate geldt dit voor de mannen die op zondagmiddag op visite gaan. Van degenen met werk en partner drinkt ongeveer de helft in deze drinksiluatie. Van de anderen slechts 10 tot $17 \%$ (Bijlage 4.1 en 4.2 ).

Religie blijkt bij de mannen tussen 25 en 54 jaar significant samen te hangen met de proportie drinkers in droge situaties. Van de protestante deelnemers drinken er relatief minder dan van de overige deelnemers. Sociale klasse hangt bij mannen tussen 25 en 54 jaar en bij mannen tussen 55 en 64 jaar significant positief samen met de proportie drinkers in natte situaties. 


\section{De vrouwen}

In tabel 6.1 .2 wordt een overzicht gepresenteerd van de resultaten van de logit-analyses per leeftijdscategorie bij de vrouwen. Bij vrouwen ouder dan 55 jaar werden geen significante verbanden tussen rollen en het al dan niet drinken van deelnemers aan categorieen van drinksituaties gevonden.

Tabel 6.1 .2

Signifikante odds ratios (niet drinken:wel drinken) in droge, medium en natte situaties bif wrouwen in verschillende leeftijdscategorieën.

\begin{tabular}{|c|c|c|c|c|c|c|}
\hline & droog & $\begin{array}{l}24 \text { jaar } \\
\text { medium }\end{array}$ & mat & droog & $\begin{array}{l}-54 \text { jaar } \\
\text { medium }\end{array}$ & nat \\
\hline Allen & 2.95 & 1.59 & .66 & 1.28 & .73 & .76 \\
\hline Werk & - & - & .25 & - & .55 & - \\
\hline School & - & - & 1.5 & & n.v.t & \\
\hline Huiswrouw & & n.v.t & & - & 1.07 & - \\
\hline Anders & - & - & .28 & - & .67 & - \\
\hline Geen Partner & - & - & . & 1.71 & - & 1.60 \\
\hline Partner & - & - & - & .96 & - & .36 \\
\hline Geen Kinderen & - & - & - & - & - & - \\
\hline Wel Kinderen & - & - & - & - & - & - \\
\hline Lagere Klasse & - & - & - & 1.85 & - & - \\
\hline Hogere Klasse & - & - & - & .96 & . & - \\
\hline Geen Religie & - & - & $=$ & .79 & .49 & - \\
\hline Rooms Katholiek & - & - & - & 1.54 & .84 & - \\
\hline Protestant & - & - & - & 1.25 & .74 & - \\
\hline Anders & - & - & - & 1.74 & .95 & - \\
\hline
\end{tabular}

Bij vrouwen jonger dan 25 jaar is de arbeidspositie een belangrijke factor in het verklaren van het al dan niet drinken in natte situaties (café-bezoek). Van alle deelnemende jonge vrouwen drinken er in deze situaties meer well dan niet $(60 \%$ drinkers); onder de schoolgaande/studerende jonge vrouwen zijon er voor elke 2 die in deze situaties drinken 3 die niet drinken. Bij de andere jonge vrouwen is er voor elke 4 drinkende deelneemsters aan natte situaties daarentegen slechts 1 die niet drinkt. Ook bij vrouwen tussen 25 en 54 jaar zijn er significante relaties tussen positierollen en de proportie drinkende deelneemsters in categorieèn van drinksituaties. Binnen de droge situaties is er een verband tussen wel of niet drinken van deelneemsters en de rol van partner. Onder de vrouwen zonder partner bevinden zich minder drinkers dan niet-drinkers. Onder degenen met partner zijn er iets meer drinkers dan nietdrinkers. In de medium situaties blijken er van de deelnemende huisvrouwen evenveel te zijn 
die wel als die niet drinken. Van de deelnemende werkende vrouwen darantegen drinken er twee maal zoveel wel als niet. Onder de rest van de wrouwen is de verhouding drinkentniet drinken $3: 2$.

In de natte situaties is de rol van partner wederom van belang. Onder degenen met partner zijn er drie maal zoveel drinkers als niet-drinkers. De partnerlozen daarentegen, drinken als ze deelnemen aan natte situaties vaker niet dan wel.

Bij vrouwen van middelbare leeftijd blijkt het percentage drinkende deelneemsters zowel in droge als in medium situaties het hoogst te zijn binnen cle categorieën zonder religie. In droge situaties blijkt verder dat van de deelnemende vrouwen uit de hogere sociale klassen ongeveer de helft drinkt terwijl dat in de lagere klassen $35 \%$ is.

\section{Conclusies}

Op basis van de hierboven gepresenteerde resultaten moet de veronderstelling dat het percentage drinkende deelnemers aan drinksituaties bij mensen zonder structurerende positierollen hoger is dan bij mensen met structurerende positierollen (hypothese 6) worden verworpen. In alle gevallen waar significante verbanden tussen positierollen en de proportie drinkers worden geconstateerd blijkt deze proportie bij degenen met structurerende positierollen hoger te zijn dan bij degenen zonder structurerende rollen. Hypothese 8 veronderstelt dat verbanden tussen positierollen en de proportie drinkende deelnemers aan drinksituaties in nattere situaties minder sterk zullen zijn. Het volledig ontbreken van significante verbanden tussen positierollen en de proportie drinkende deelnemers aan natte situaties bij de mannen kan als een bevestiging wan deze hypothese worden opgevat.

Statusrollen hebben zoals verondersteld (hypothese 10) naast positierollen invloeden op de proportie van de deelnemers aan drinksituaties die in die situaties ook drinkt. Sociale klasse hangt positief samen met de proportie van de deelnemers die drinkt binnen de natte situaties bij mannen tussen 25 en 54 jaar en tussen 55 en 64 jaar en binnen de droge situaties bij.j vrouwen tussen 25 en 54 jaar. Geen religie en Rooms-katholicisme (alleen mannen) hangt eveneens positief samen met de proportie drinkende deelnemers en wel in droge situaties (mannen en vrouwen tussen 25 en 54 jaar) en medium situaties (mannen 25-54 jaar).

Alle hier gepresenteerde verbanden betreffen die respondenten die tijdens de dagboekweek hebben gedronken. Per categorie van drinksituaties zijn de anallyses alleen bij deelnemers uitgevoerd. De afhankelijke variabele is het aantal drinkers gedeeld door het antal deelnemers. Het geringe aantal drinkers bij oudere vrouwen kan verklaren watrom er in deze categorie geen verbanden tussen rollen en drinkgedrag worden gevonden. 


\subsection{Rollen en intensiteit van drinkgedrag}

Naast de hypothesen betreffende het al dan niet drinken bij deelname aan categorieën van drinksutuaties zijn er ook een aantal hypothesen geformuleerd over de relatie tussen rollen en de intensiteit van drinkgedrag van degenen die alcohol gebruiken binnen categorieen wan drinksituaties. De resultaten van hoofdstuk 5 bevestigen dat er positieve verbanden zijn tussen. de expositie aan drinksituaties en de consumptie in die situaties. Hypothese 7 stelt dat mensen

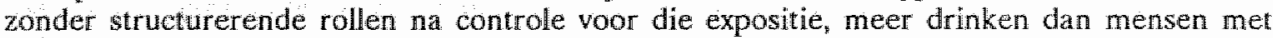
structurerende rollen. Hypothese 9 stelt dat de verbanden tussen structurerende rollen en de voor expositie gecontroleerde consumptie in nattere situaties minder sterk zijn. Hypothese 11 tenslotte, stelt dat ook na controle voor expositie en positierollen, statusrollen een deel van de variantie in consumptie van drinkers in drinksituaties kunnen verklaren. Deze hypothesen zijn onderzocht door middel van multiple regressie analyses waarbij eerst expositie, vervolgens positierollen en tenslotte statusrollen als onafhankelijke variabelen zijn ingevoerd. De analyses zijn verricht bij de drinkers per categorie van drinksituaties.

\section{De mainnen}

De resultaten van de regressie analyses binnen de verschillende leeftijdscategorieën bij de mannen worden gepresenteerd in tabel 6.2.1.

Zowel bij jonge mannen als bij mannen tussen 25 en 54 jaar blijkt werk na controle voor expositie, positief samen te hangen met de totale consumptie in drinksituaties. Bij de jonge mannen komt dit verband voort uit een negatieve relatie tussen de rol van scholier/student en de voor expositie gecontroleerde, consumptie in medium situaties. Scholieren/studenten drinken bij gelijke blootstelling aan medium situaties minder dan hun niet studerende leeftijdsgenoten. Niet-werkende mannen tussen 25 en 54 jaar drinken na controle voor expositie, minder in droge situaties dan hun werkende leeftijdsgenoten. Büj mannen tussen 55 en 64 jaar, hangt de rol van partner negatief samen met de consumptie in droge situaties.

De statusrol sociale klasse blijkt bij mannen tussen 25 en 54 jaar significant positief samen te hangen met de consumptie in droge situaties. Dit effect blijkt ook in de totale consumptie. Zowel bij de jongeren als bij de mannen tussen 25 en 54 jaar hangt protestantisme negatief samen met de voor expositie en positierollen gecontroleerde, consumptie in medium drinksituaties. Bij de mannen ouder dan 55 ja kunnen na controle voor positierollen en expositie, geen verbanden tussen statusirollen en consumptie in drinksituaties worden geconstateerd. Binnen natte situaties worden na controle voor expositie in geen enkele leeftijdscategorie significante verbanden tussen rollen en consumptie gevonden. 


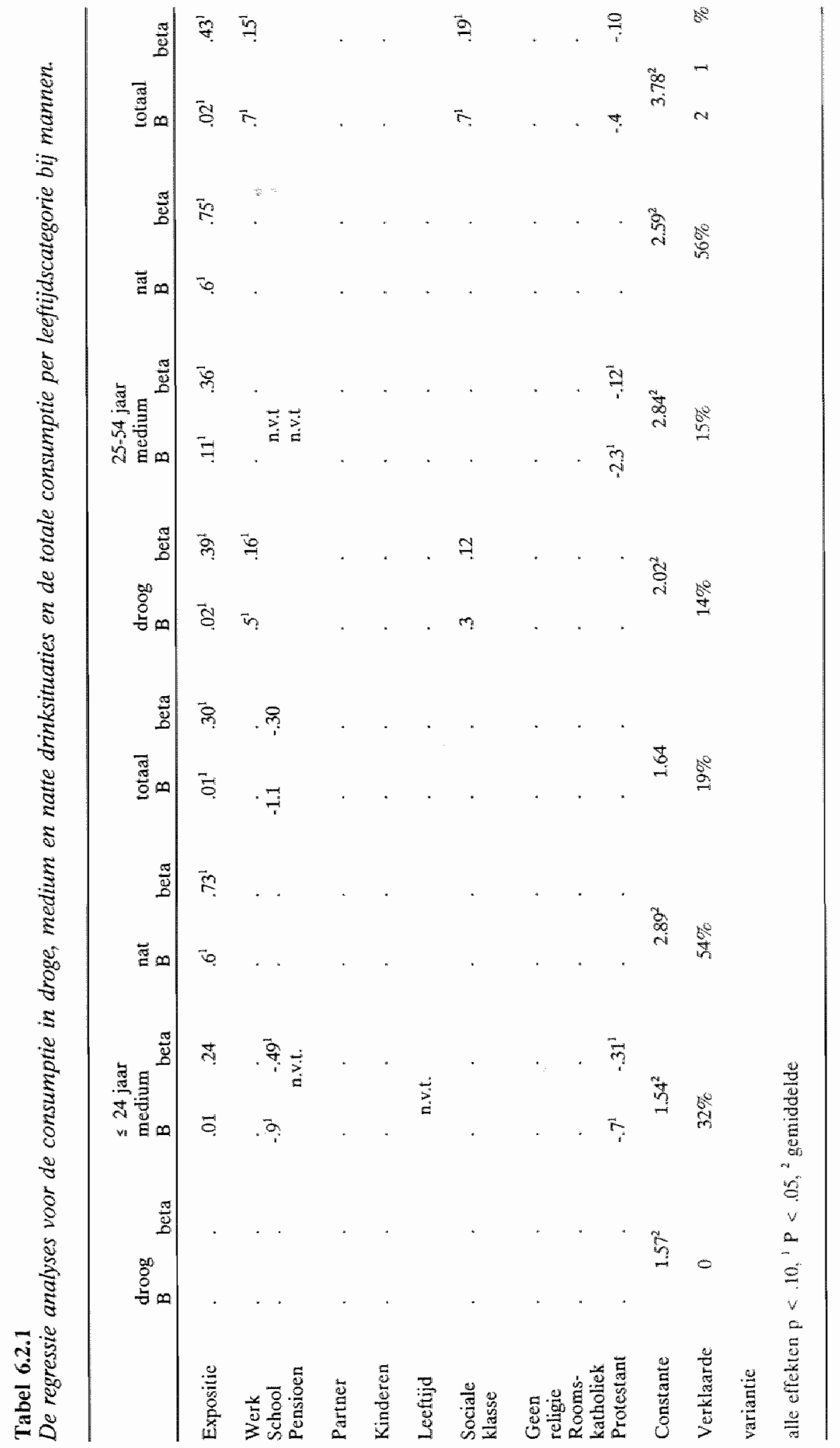




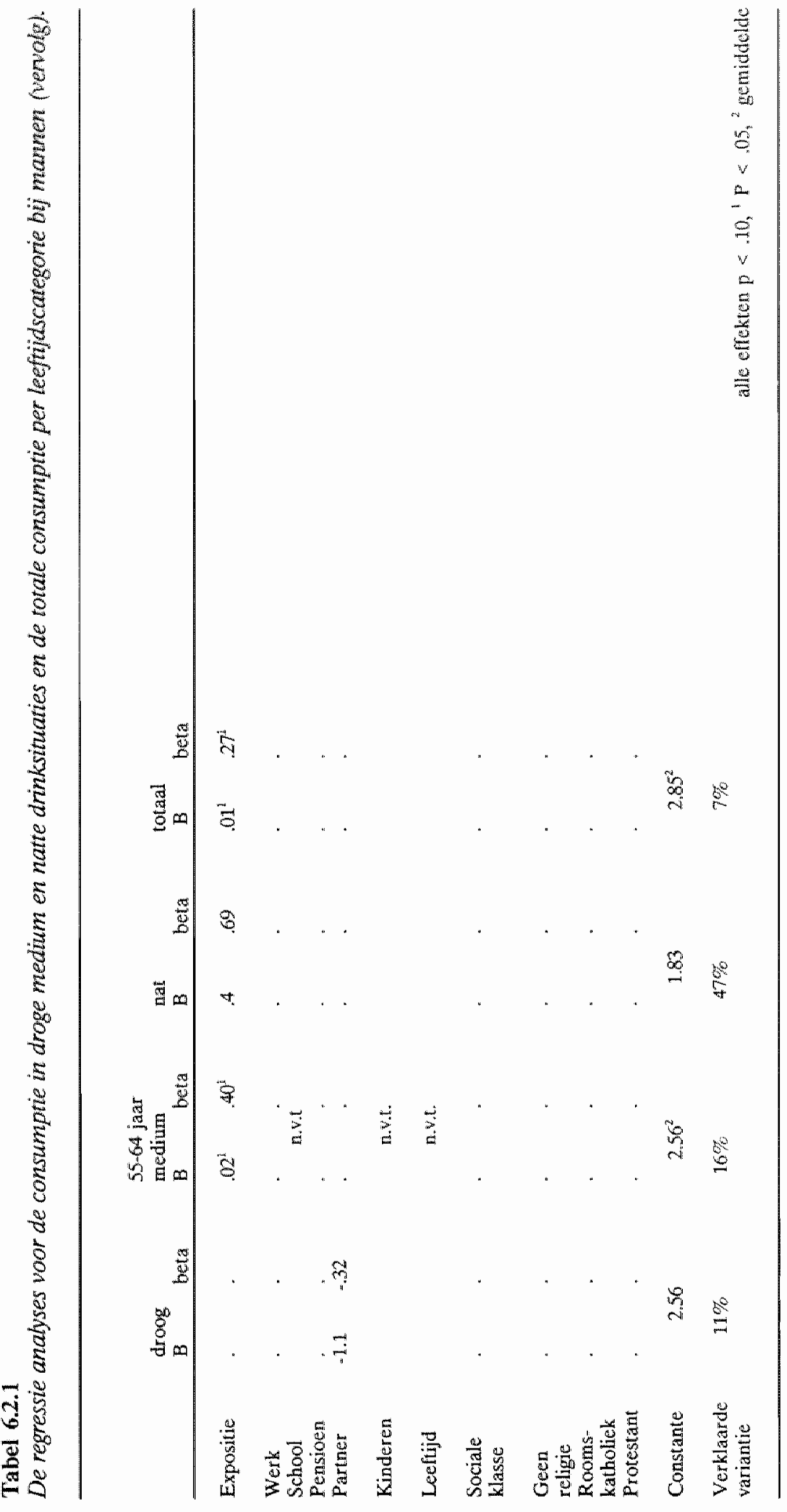




\section{De vrouwen}

De resultaten van de regressie analyses binnen de verschillende leeftijdscategorieèn bij de vrouwen worden gepresenteerd in tabel 6.2.2.

De enige positierol die bij vrouwen significant met de voor expositie gecontroleerde, consumptie samenhangt is de rol van werkende bij vrouwen tussen 25 en 54 jaar. Werk blijkt na controle voor expositie, bij vrouwen tussen 25 en 54 jaar positief samen te hangen met de consumptie in droge drinksituaties. Ook in de totale consumptie komt dit effect significant tot uiting. Bij vrouwen tussen 25 en 54 jaar blijken leeftijd, sociale klasse en religie na controle voor expositie en positierollen, significant samen te hangen met de consumptie in drinksituaties. Sociale klasse hangt negatief samen met de consumptie in natte situaties, geen religie heeft een positief effect op de consumptie in droge situaties en de totale consumptie. Bij de jongere vrouwen is er een negatief verband tussen protestantisme en de voor expositie gecontroleerde, consumptie in droge situaties. In geen der categorieën van drinksituaties blijken bij jonge vrouwen invloeden van sociale klasse op de consumptie. Sociale klasse blijkt echter wel significant negatief samen te hangen met de totale voor expositie gecontroleerde, consumptie. Binnen de categorie vrouwen tussen 25 en 54 jaar hangt leeftijd negatief samen met de voor expositie gecontroleerde, consumptie in medium situaties en de totale voor expositie gecontroleerde, consumptie.

Bij oudere vrouwen ( $\geq 55$ jaar) werden geen significante verbanden tussen rollen en de intensiteit van drinkgedrag ontdekt.

\section{Conclusies}

In dit hoofdstuk zijn relaties tussen rollen en intensiteit van drinkgedrag behandeld. Ten aanzien van de verklaring van consumptie in drinksituaties is ook al in hoofdstuk 5 gebleken dat de expositie aan die situaties een dominante plaats inneemt. Effecten van rollen op de consumptie die overblijven na controle voor expositie kunnen als effecten op intensiteit van drinkgedrag worden opgevat.

Op basis van de hierboven gepresenteerde resultaten moet de veronderstelling dat de voor expositie gecontroleerde consumptie van mensen zonder structurerende positierollen hoger is dan die van mensen met structurerende positierollen (hypothese 7), verworpen worden. Slechts in een geval wordt een negatieve relatie tussen een structurerende rol en de voor expositie gecontroleerde, consumptie gevonden (mannen 55-64 jaar, partner).

De rol van werkende hangt positief samen met de consumptie, zowel bij jonge mannen (medlum situaties) als bij mannen en vrouwen tussen 25 en 54 jaar (droge situaties). De zorg voor jonge kinderen heeft, na controle voor expositie, geen significante invloeden op de consumptia. Er worden geen verbanden gevonden tussen de voor expositie gecontroleerde consumptie in natte situaties en positierollen. Dit is in overeenstemming met hypothese 9 . Verbanden tussen positierollen en consumptie nemen af met de natheid van de situaties. Het verband tussen expositie aan natte situaties en consumptie in die situaties is zo sterk dat rollen geen bijdrage meer leveren aan de verklaring van variantie in consumptie binnen die situaties. 


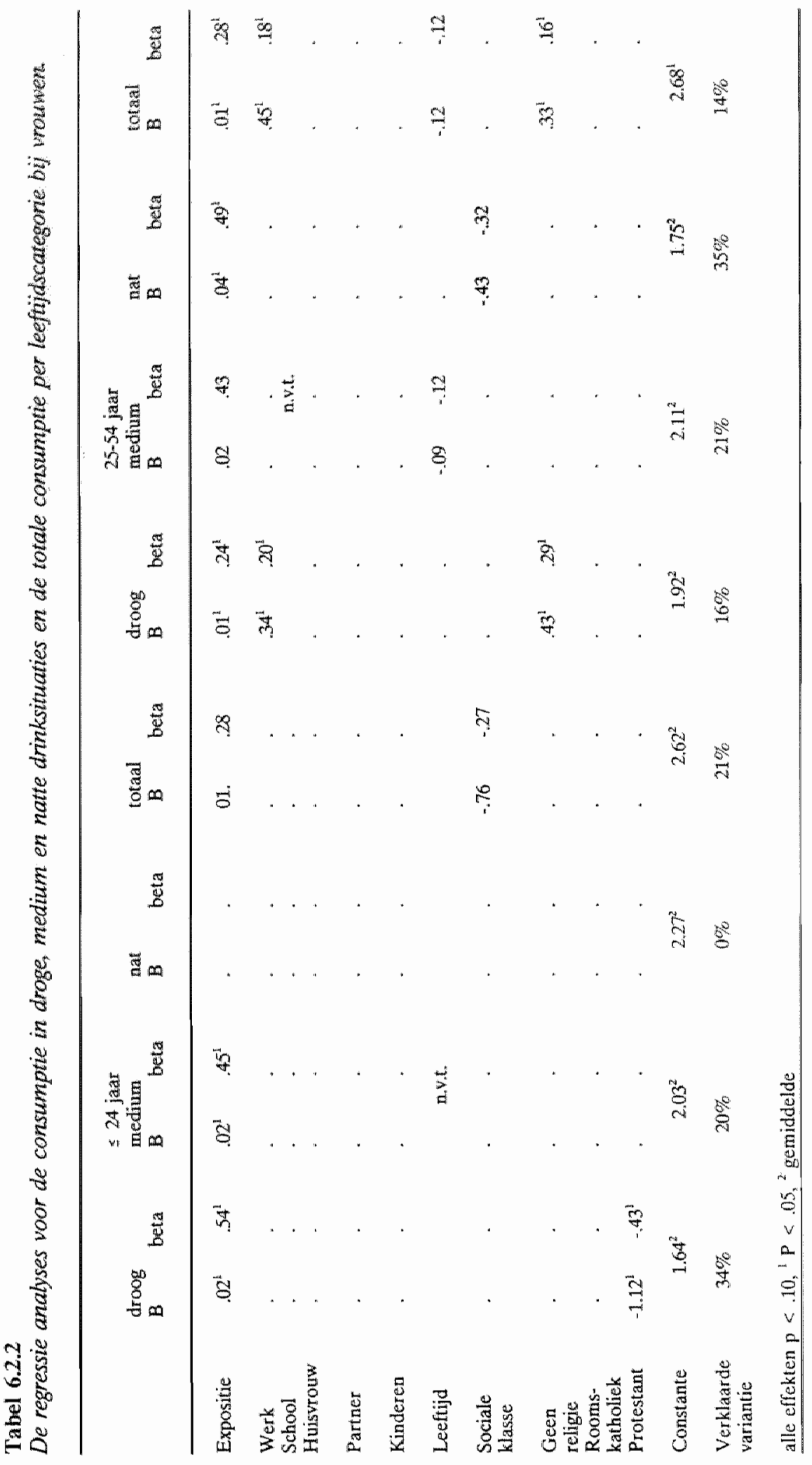


Ook na controle voor positierollen en expositie worden nog enkele signuficante verbanden tussen statusrollen en de consumptie in categorieen van drinksituaties gevonden (hypothese 11). Mannen (25-54 jaar) uit de hogere sociale klassen hebben een intensiever drinkgedrag in droge situaties dan hun leeftijdsgenoten uit de lagere sociale klassen. Bij vrouwen cussen 25 en 54 jaar blijkt in natte situaties het tegenovergestelde. Vrouwen uit de hogere sociale klassen drinken minder intensief. Protestante mannen (25-54 jaar) drinken minder intensief binnen medium situaties dan hun leeftijdsgenoten met een andere of zonder religieuze overtuiging. Bij de vrouwen (25-54 jaar) zijn het degenen zonder religie die intensiever drinken (droge situaties en totaal).

\subsection{Consumptieniveau en rollen}

Uitgaande van een algemeen effect op de intensiteit van drinkgedrag zijn er een aantal hypothesen geformuleerd omtrent relaties tussen rollen en de verdeling van de populatie in mensen die niet hebben gedronken tijdens de dagboekweek en lichte, medium en zware drinkers. Hypothese 12 stelt dat het percentage zware drinkers lager is bij mensen met structurerende rollen dan bij mensen zonder structurerende rollen. Hypothese 14 stelt dat het deel wan de populatie dat tijdens de dagboekweek niet drinkt het hoogst is bij mensen met structurerende rollen.

Verbanden tussen consumptieniveau en positierollen zijn onderzocht door middel van $X^{2}$-toetsen. De toetsen tonen aan dat in de mannelijke populatie de zware drinkers relatief ondervertegenwoordigd zijn in de categorie zonder werk en in de categorie zonder partner. Bij de werkenden zijn in vergelijking tot de niet werkenden ook significant minder mensen die niet drinken tijdens de dagboekweek ( $15 \%$ versus $31 \%, X^{\prime \prime}=16.99$, df $=1$ ).

Behalve met de rollen van Werkende en Partner binnen de mannelijke populatie zijn er geen verbanden tussen afzonderlijke positierollen en de zwaarte van het drinkgedrag.

Een toets voor de relatie tussen de combinatie van rollen (rolset) en de zwaarte van het drinkgedrag (tabellen 6.3.1 en 6.3.2) resulteert bij de mannen in een significante $X^{2}$-score. Dit betekent dat de verdeling van de populatie in lichte, medium en zware drinkers niet bij alle combinaties van positierollen gelijk is.

De hoge $X^{2}$-score is bijna volledig toe te schrijven aan het relatief grote antal lichte drinkers onder de mannen die geen enkele structurerende positierol vervullen $(60 \%$ van de drinkers in deze categorie behoort tot de lichte drinkers).

Bij de wrouwen is er geen significante samenhang tussen de combinatie van positierollen en het consumptieniveau in de dagboekweek. Wel valt op dat van de drinkers in de categorie zonder structurerende rollen de helft tot de lichte drinkers behoort terwijl van de werkenden met partner $49 \%$ en van de huisvrouwen zonder partner $5 \% \%$ wan de drinkers zware drinkers zijn. 
Tabel 6.3.1

Percentage lichte, matige en zware drinkers en percentage mensen dat niet gedronken heeft tijdens de dagboekweek naar combinatie van positierollen (mannen).

\section{Work \\ Partner \\ Kinderen}

Lichte drinkers

Matige drinkers

Zware drinkers

Aantal drinkers( $N)$

Niet gedronken (\%)

Totaal (N)

$\begin{array}{ll}60 & 30 \\ 26 & 39 \\ 14 & 32 \\ 43 & 57\end{array}$

34

65

30
39
32
57

25

76

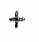

$+\frac{1}{+}+$

$+$

$+$

Categorieën drinkers $X^{4}=22.40, \mathrm{DF}=4$

Wel/niet drinken $X^{2}=22.17, \mathrm{DF}=8$

\section{Tabel 6.3.2}

Percentage lichte, matige en zware drinkers en percentage mensen dat niet gedronken heeft tijdens de dagboekweek naar combinatie van positierollen (vrouwen).

\begin{tabular}{|c|c|c|c|c|c|c|}
\hline Werk & - & + & + & h & $\mathrm{h}$ & b \\
\hline Partner & - & - & t. & - & + & + \\
\hline Kinderen & - & - & - & - & - & + \\
\hline Lichte drinkers & 50 & 38 & 28 & 24 & 33 & 31 \\
\hline Matige drinkerss & 25 & 38 & 23 & 18 & 36 & 39 \\
\hline Zware drinkers & 25 & 24 & 49 & 59 & 30 & 31 \\
\hline Totaal drinkers (n) & 32 & 37 & 39 & 17 & 66 & 49 \\
\hline Niet gedronken (\%) & 32 & 31 & 17 & 48 & 35 & 39 \\
\hline $\begin{array}{l}\text { Totaal (N) } \\
h=\text { huisvrouw }\end{array}$ & 47 & 54 & 47 & 33 & 102 & 80 \\
\hline $\begin{array}{l}\text { Categorieen drinkers } \\
\text { Wel/niet drinken }\end{array}$ & $\begin{array}{l}.02, \\
39, \mathrm{r}\end{array}$ & $\begin{array}{l}0, \mathrm{P} \\
{ }_{\mathrm{P}} \mathrm{P}\end{array}$ & & & & \\
\hline
\end{tabular}


Ten aanzien wan statusrollen zouden op grond van de resultaten van de resultaten in paragrafen 6.1 en 6.2 enkele significante samenhangen met consumptieniveau mogen wordien verwach: Deze verwachting is ook uitgesproken in hypothesen 13 en 15 .

Het aantal lichte, matige en zware drinkers alsmede het antal mensen dat niel gedronken heeft in de dagboekweek per statusrol is weergegeven in tabellen 6.3 .3 tot 6.3 .8 .

Tabel 6.3.3

Percentage lichte, matige en zware drinkers en percentage mensen dat niet gedronken heeft tijdens de dagboekweek naar leeftijdscategorie (mannen).

\begin{tabular}{|c|c|c|c|c|c|c|}
\hline & $\begin{array}{l}\leq 24 \\
\text { jaar }\end{array}$ & $\begin{array}{l}25-34 \\
\text { jaar }\end{array}$ & $\begin{array}{l}35 \times 44 \\
\text { jadr }\end{array}$ & $\begin{array}{l}45-54 \\
\text { jaar }\end{array}$ & $\begin{array}{l}55+64 \\
j a \mathrm{ar}\end{array}$ & $\begin{array}{l}\geq 05 \\
\text { jaar }\end{array}$ \\
\hline Lichte drinkers & 51 & 34 & 21 & 27 & 38 & 23 \\
\hline Matige drinkers & 36 & 31. & 33 & 45 & 38 & 38 \\
\hline Zware drinkers & 14 & 34 & 46 & 28 & 24 & 38 \\
\hline Totaal drinkers $(\mathbb{N})$ & 59 & 105 & 96 & 67 & 55 & 13 \\
\hline Niet gedronken $(\%)$ & 32 & 13 & 11 & 21 & 25 & 35 \\
\hline Totaal (N) & 87 & 120 & 108 & 85 & 73 & 20 \\
\hline \multicolumn{7}{|c|}{$\begin{array}{l}\text { Categorieën drinkers } X^{2}=28.13, \mathrm{DF}=10, \mathrm{P}=.0017 \\
\text { Wel/niet drinken } \quad X^{\prime \prime}=21.59, \mathrm{DF}=5, \mathrm{P}<.001\end{array}$} \\
\hline
\end{tabular}

De enige statusrol die significant samenhangt met de zwaarte van het drinkgedrag is leeftijd. Dit is zowel het geval in de mannelijke als in de vrowwelijke populatie. Het percentage zware drinkers is het hoogst bij de categorieën van middelbare leeftijd, het percentage lichte drinkers is het hoogst buj de jongeren en de ouderen. Het a antal mannen dat tijdens de dagboekweek geen alcohol gebruikt heeft warieert op vergelijkbare wijze met leeftijd. Terwijl bij mannen tussen 25 en 34 jaar $(13 \%$ ) en tussen 35 en 44 jatar (11\%) slechts een klein deel niet drinkt zija er onder de jongeren (32\%) en de ouderen (35\%) relatief veel die niet drinken tijdens de dagboekweek. Bij vrouwen is er geen verband tussen al dan niet trinken tijdens de dagboekweek en leeftijd. 
Tabel 6.3 .4

Percentage lichte, matige en zware drinkers en percentage mensen dat niet gedronken heeft tijdens de dagboekweek naar leeftijdscategorie (wrouwen).

\begin{tabular}{lcccccc}
\hline & $\begin{array}{l}\leq 24 \\
\text { jaar }\end{array}$ & $\begin{array}{l}25-34 \\
\text { jaar }\end{array}$ & $\begin{array}{l}35-44 \\
\text { jaar }\end{array}$ & $\begin{array}{l}45-54 \\
\text { jaar }\end{array}$ & $\begin{array}{l}55-64 \\
\text { jaar }\end{array}$ & $\begin{array}{l}\geq 65 \\
\text { jaar }\end{array}$ \\
\hline $\begin{array}{l}\text { Lichte drinkers } \\
\text { Matige drinkers }\end{array}$ & 48 & 35 & 19 & 30 & 37 & 25 \\
Zware drinkers & 34 & 38 & 32 & 33 & 31 & 25 \\
Totaal drinkers $(\mathrm{N})$ & 18 & 28 & 49 & 37 & 31 & 50 \\
Niet gedronken $(\%)$ & 50 & 72 & 59 & 43 & 35 & 16 \\
Totaal $(\mathrm{N})$ & 40 & 34 & 29 & 33 & 41 & 36 \\
$\begin{array}{l}\text { Categorieen dinkers } X^{\prime \prime}=18.61, \mathrm{DF}=10, \mathrm{P}<.05 \\
\text { Wel/niet drinken }\end{array} X^{\prime \prime}=3.21, \mathrm{DF}=5, \mathrm{P}>.05$ & & & & & \\
\hline
\end{tabular}

Uit de logit analyses bleken zowel bij mannen als bij vrouwen enkele significante positieve verbanden tussen het al dan niet crinken in categorieèn van drinksituaties en sociale klasse. Inderdaad is het percentage zware drinkers thet hoogst en het percentage lichte drinkers of mensen dat niet heeft gedronken het laagst in de hogere sociale klasse. Deze verschillen zijn echter niet groot genoeg om tot significante $X$-scores te leiden.

Uit de resultaten in de vorige paragrafen bleek dat protestantisme negatief samenhangt met alcoholgebruik. Het aantal zware drinkers onder de protestanten ( $20 \%$ bij de mannen en $25 \%$ bij de vrouwen) is lager dan dat in de categorie zonder religie ( $38 \%$ bij mannen en $39 \%$ bij vrouwen). Deze verschillen zijn echter eveneens niet groot genoeg om tot een significante $X^{2}$. score te leiden. 


\section{Tabel 6.3 .5}

Percentage lichte, matige en zware drinkers en percentage mensen dat niet gedronken heett tijdens de dagboekweek naar sociale klasse (mannen).

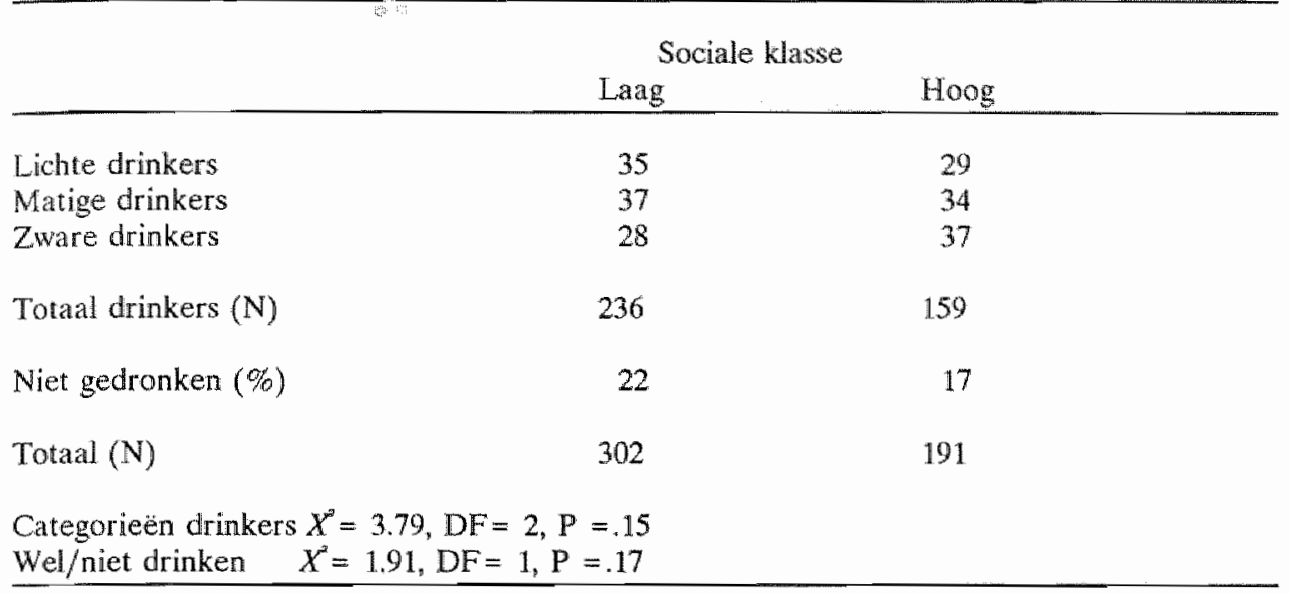

\section{Tabel 6.3.6}

Percentage lichte, matige en zware drinkers en percentage mensen dat niet gedronken heeft tijdens de dagboekweek naar sociale klasse (vrouwen).

\begin{tabular}{lcc}
\hline & Sociale klasse & Hoog \\
\hline & Laag & 31 \\
Lichte drinkers & 34 & 32 \\
Matige drinkers & 34 & 37 \\
Zware drinkers & 31 & 121 \\
Totatal drinkers $(\mathrm{N})$ & 154 & 30 \\
Niet gedronken $(\%)$ & 39 & 172 \\
Totaal (N) & 251 & \\
Categorieen drinkers $X^{2}=1.13, \mathrm{DF}=2, \mathrm{P}=.57$ & \\
Wel/niet drinken & $X^{2}=3.62, \mathrm{DF}=1, \mathrm{P}=.056$ & \\
\hline
\end{tabular}


Tabel 6.3.7

Percentage hichte, matige en zware drinkers en percentage mensen dat niet gedronken heeft tijdens de dagboekweek naar religie (mannen).

\begin{tabular}{|c|c|c|c|c|}
\hline & $\begin{array}{l}\text { Geen } \\
\text { religie }\end{array}$ & $\begin{array}{l}\text { Rooms } \\
\text { katholiek }\end{array}$ & Protestant & anders \\
\hline Lichte drinkers & 30 & 31 & 40 & 27 \\
\hline Matige drinkers & 32 & 37 & 40 & 42 \\
\hline Zware drinkers & 38 & 33 & 20 & 30 \\
\hline Total drinkers $(N)$ & 175 & 95 & 92 & 33 \\
\hline Niet gedronken $(\%)$ & 18 & 17 & 24 & 23 \\
\hline Total $(N)$ & 214 & 115 & 121 & 43 \\
\hline \multicolumn{5}{|c|}{$\begin{array}{l}\text { Cattegorieën drinkers } X^{*}=10.31, \mathrm{DF}=6, \mathrm{P}=.11 \\
\text { Wel/niet drinken } \quad X^{*}=2.39, \mathrm{DF}=3, \mathrm{P}=.495\end{array}$} \\
\hline
\end{tabular}

\section{Tabel 6.3.8}

Percentage lichte, matige en zware drinkers en percentage mensen dat niet gedronken heeft tijdens de dagboekweek naar religie (vrouwen).

\begin{tabular}{|c|c|c|c|c|}
\hline & $\begin{array}{l}\text { Geen } \\
\text { religie }\end{array}$ & $\begin{array}{l}\text { Rooms } \\
\text { katholiek }\end{array}$ & Protestant & Anders \\
\hline Lichte drinkers & 32 & 27 & 35 & 50 \\
\hline Matige drinkers & 21 & 35 & 40 & 33 \\
\hline Zware drinkets & 39 & 38 & 25 & 17 \\
\hline Totaal drinkers $(\mathrm{N})$ & 120 & 74 & 57 & 24 \\
\hline Niet gedronken $(\%)$ & 33 & 37 & 38 & 31 \\
\hline Totaal $(\mathrm{N})$ & 179 & 117 & 92 & 35 \\
\hline \multicolumn{4}{|c|}{ Categorieen drinkers $X^{2}=9.49, \mathrm{DF}=6, \mathrm{P}=15$} & Wel/niet drinken $X^{\prime \prime}=1.06, \mathrm{DF}=1, \mathrm{P}=.78$ \\
\hline
\end{tabular}




\section{Conclusies}

Hypothesen 12 tot en met 15 betreffen samenhangen tussen rollen an de verdeling wan de populatie in lichte, medium en zware drinkers alsmede die tussen rollen en het a! dan niet drinken tijdens de dagboekweek. Indien er algemene verbanden tussen rollen en intensiteit van drankgebruik zouden zijn zou dit ook tot uiting moeten komen in de verdeling van drinkers over deze categorieen. Er worden nawwelijks significante verbanden tussen rollen en deze verdeling gevonden. Alleen bij de mannen blijken significante verbanden tussen de rollen van werkende en van partner en de zwaarte van het drinkgedrag. In beide gevallen zijn de werbanden positief (meer zware drinkers onder degenen met de structurerende rol). Dit is in tegenspratk met hypothese 12 .

Ook het aantal lichte drinkers en het aantal mensen dat niet drinkt is het hoogst bij degenen die niet werken. Dit is in tegenspraak met hypothese 14.

Rolset (combinatie van positierollen) hangt bij de mannen significant samen met de verdeling van de populatie in lichte, medium en zware drinkers. De meeste lichte drinkers (relatief) bevinden zich, in tegenstelling tot de hypothese in de groep zonder structurerende rollen. Dit kan waarschijnlijk worden verklaard uit het feit dat deze categorie voornamelijk uit jongeren bestaat.

Leeftijd blijkt significant met de zwaarte van het drinkgedrag samen te hangen. De meeste zware drinkers worden gevonden in de leeftijdscategorie van $35-44$ jaar. Tot deze leeftijd stijgt het percentage zware drinkers daarna daalt het. In de percentages van de populatie dat niet drinkt tijdens de dagboekweek en het aantal lichte drinkers per leeftijdscategorie, kan een tegenovergesteld patroon worden waargenomen. Ook in de vrouwelijke populatie blijken deze patronen in de percentages lichte, medium en zware drinkers aanwezig te zijn.

Hoewel de resultaten wan de analyses aangaande de relatie tussen de religie en sociale klasse en de verdeling van de drinkers overeenstemmen met die van de logit- en regressie- analyses zijn er geen significante verbanden tussen deze rollen en de zwaarte van hel clrinkgedrag gevonden. Aangaande religie en sociale klasse moeten hypothese 13 en 15 worden verworpen.

\subsection{Algemene conclusies}

In dit hoofdstuk zijn de relaties tussen positie- en statusrollen en het 'normale' gebruik van alcohol in het dagelijks leven onderzocht. Hiervoor zijn drie verschillende methoden van analyse gebruikt. Door middel van logit analyses is onderzocht hoe proporties drinkende deelnemers aan categorieën wan drinksituaties samenhangen met pasitie- of statusrollen. Door middel wan multiple regressie analyses is onderzocht hoe de voor expositie gecontroleer de, consumptie wan drinkers binnen categorieën van drinksituaties warieert met rollen. Door middel van $X$-toetsen is onderzocht hoe rollen en rolset samenhangen met de verdeling van de populatie in lichte, matige en zware drinkers en in de verdeling in mensen die drinken en mensen die niet drinken tijdens de dagboekweek.

De algemene conclusie uit alle analyses is dat structurerende positierollen (met name werk) een positief effect hebben op het gebruik wan alcohol. De enige uitzondering hierop wordt gevormal door het negatieve verband tussen de rol van partner en de voor expositie gecontroleerde consumptie in droge drinksituaties van mannen tussen 55 en 64 jaar.

Werk hangt bij mannen en vrouwen positief samen met zowel het percentage drinkende deelnemers aan drinksituaties als met de gemiddelde consumptie van de drinkers binnen droge en medium drinksituaties. Ook het percentage zware drinkers is bij werkende mannen het 
hoogst. Verschillen in drankgebruik die na controle woor expositie overblijen, zijn verschillen in de intensiteit van drinkgedrag. De categorie der 'stress' hypothesen (Winton et al., 1986) veronderstelt dat spanningen tot een intensiever drankgebruik zouden leiden. Met name werkloosheid zou een bron wan spanningen zijn. In deze studie zijgn spanningen of stress niet gemeten. Uit de invloeden van rollen op de consumptie blijkt echter wel dat de stresshypothesen, zeker ten aanzien van werkloosheid geen steun vinden. De structurerende rol van werkende hangt positief samen met de intensiteit van drinkgedrag. Uitgaande van een positieve relatie tussen werkloosheid en stress of spanningen (Haworth en Evans, 1987) moet daarom worden aingenomen dat de veronderstelde relatie tussen stress of spanningen en drankgebruik (o.d. Vollpicelli, 1987) niet opgat.

De rol van partner hangt, behalve bij bovengenoemd geval, positief samen met het percentage drinkende deehnemers aan drinksituaties. Bij mannen geldt dit in medium situaties en bij vrouwen in droge en natte situaties. Bij mannen met partner is eveneens het percentage zware drinkers hoger dan bij mannen zonder partner.

De droge drinksituaties bij de vrouwen zijn qua definiërende activiteit en tijdstip vergelijkbaar met de medium drinksituaties bij de mannen. Het betreft met name gezellige of sociale situaties in het eigen gezin of bij kennissen of familie (eten, visite, televisiekijken, sociale contacten met huisgenoten). Een mogelijke verklaring voor de hogere proportie drinkers in dit soort situaties bij mannen en vrouwen met partner zou kunnen zijn dat wanneer men samen met zijn of haar partner in dergelijke situaties is eerder tot drankgebruik overgegaan wordt om het sociale, gezellige karakter van het samenzijn te onderstrepen.

De natte situaties betreffen bij de vrouwen alleen café-bezoek. Aanwezigheid van de partner zou ook hier kunnen verklaren waarom vrouwen met partner meer drinken dan degenen zonder partner. Deze veronderstellingen kunnen hier niet onderzocht worden omdat in het gebruikte materiaal geen informatie omtrent aanwezigen in de drinksituatie voorhanden is.

Zorg voor jonge kinderen hangt niet significant samen met het gebruik van alcohol.

Ten aanzien van religie blijkt uit alle analyses een matigend effect van protestantisme op het gebruik van alcoholhoudende dranken. Bij mannen en bij vrouwen blijken er relatief minder drinkende deelnemers te zijn onder protestanten en is de gemiddelde consumptie van protestanten lager. Ook het percentage zware drinkers is relatief laag in het protestante deel van de populatie al leidt dit niet tot significante uitkomsten van de betreffende $X^{2}$-toetsen.

De effecten van sociale klasse op het drankgebruik zijn minder eenduidig. Bij mannen worden alleen positieve effecten gevonden. Bij vrouwen blijken daarnaast ook negatieve verbanden. De totale consumptie van jonge vrouwen en de consumptie in natte situaties van vrouwen tussen 25 en 54 jaar hangen na controle voor expositie negatief samen met sociale klasse. Bij vrouwen tussen 25 en 54 jaar hangt sociale klasse positief samen met de proportie drinkende deelneemsters aan droge drinksituaties.

Meer nog dan bij de analyses betreffende de expositie aan drinksituaties ontstaan er bij de analyses van intensiteit van drinkgedrag problemen door de geringe omvang van de onderzoekspopulaties. Met name bij jongeren en ouderen is het aantal drinkers niet al te hoog. Het is dan ook niet verwonderlijk dat bij mannen en vrouwen van middelbare leeftijd de meeste significante verbanden tussen rollen en intensiteitt van drinkgedrag worden gevonden.

De analyses beschreven in dit hoofdstuk, zijn niet steeds in dezelfde populaties uitgevoerd. Alleen degenen die tijdens de dlagboekweek gedronken hebben zijn in de logit en de regressie analyses betrokken. De logit analyses zijn uitgevoerd onder degenen die aan de betreffende categorie van drinksituaties hebben deelgenomen. De regressie analyses zijn verricht bij degenen 
die ook binnen de betreffende categorie wan drinksituaties hebben gedronken. Dit verklaart waarom er, op een uitzondering na, geen verbanden tussen rollen en zowel proportie drinkers als gemiddelde consumptie van die drinkers in een van de categorieën van drinksituaties zhjn gevonden. De uitzondering betreft de invloed van religie op het drinkgedrag in medium situaties van vrouwen tussen 25 en 54 jaar.

Zouden de regressie analyses, net als de logit analyses, witgevoerd zijn bij de deelnemers aan categorieên van drinksituaties dan zouden er waarschijnljjk meer overeenstemmende resultaten zijn gevonden. De resultaten zouden in dat geval nüet eenduidig zijn omtrent de oorzaken van verbanden (meer drinkers of hogere consumptie). Gezien de resultaten, met name het ontbreken van tegengestelde effecten van een bepaalde rollen op de proportie drinkers en de consumptie van drinkers, kan geconcludeerd worden dat een dergelijke analyse geen verkeerd beeld van de relaties tussen rollen en drinkgedrag zou geven. Mede gezien de grotere onvang van de onderzoekspopulaties is het daarom wenselijk dergelijke regressie analyses in de toekomst uit te voeren onder deelnemers aan drinksituaties en niet te beperken tot de drinkers. Beter zou het zijn om te werken met een grotere steekproef warin eventueel bepaalde categorieën zijn oververtegenwoordigd. 


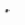




\section{Hoofdstuk 7 \\ Samenvatting en discussie}

In dit laatste hoofdstuk worden de voorafgaande hoofdstukken nog eens kort samengevat en van enkele kanttekeningen voorzien. De volgorde in dit hoofdstuk is niet precies gelijk aan die welke in het proefschrift is aangehouden. In het voorafgaande werden theorie, methoden en resultatern afzonderlijk gepresenteend. Dat is in dit hoofdstuk niet het geval Resultaten worden samen mat methoden en theoretische overwegingen die daarbij horen gepresenteerd.

Als eerste komen de sociale drinkgewoonten in Nederland aan de orde. Vervolgens worden de relaties tussen rollen en het drinkgedrag in drinksituaties beschreven. Tenslotte worden werschillen in drinkgedrag tussen lichte, matige en zware drinkers alsmede relaties tussen rollen en de zwaarte van het drankgebruik behandeld.

\section{Drinksituaties en sociale drinkgewoonten}

Het drinken van alcoholhoudende dranken is omschreven als een handeling. Handelingen zijn elementen van gedrag die hun betekenis ontlenen aan de activiteit waar ze deel van uitmaken. Bij de interpretatie van de betekenis van drinkgedrag is de primaire activiteit waarbij het plaatsvindt van belang. Alle gedrag vindt plats in situaties. Sociale actoren stemmen hun gedrag af op de wargenomen kenmerken van de situatie. De wijze warop situaties worden geinterpreteerd en keuzes voor gedragsalternatieven worden gemalakt komen voort wit en zijn de basis van de sociale structuur war de actor deel van uit makt. De orde in onze samenleving heeft een sterk mathematisch temporeel karakter. De temporele bakens voor het handelen zijn klokken en kalenders. De dag van de week en het tijdstip van de dag zijn sociale feiten warmee in de interpretatie van situaties en het handelen rekening wordt gehouden.

Een groot deel van alle drinkgedrag mag worden beschouwd als sociale gewoonte (Knibbe, 1984; Gadourek, 1963). De sociale gewoonte is een collectieve dus door anderen gedeelde, semï automatische response op stimuli in de sutuatie. De activiteit en temporele aspecten van situat lies zijn beschouwd als stimuli in reactie warop drinkgedrag tot stand komt.

Door middel van dagboekgegevens verzameld bij een representatieve steekproef uit de Nederlandse bewolking, is onderzocht in welke situaties gedefinieerd nar tijd en activiteit, drinkgedrag plaatswindt. In het dagboek moesten respondenten gedurende zeven opeenvolgende dagen per kwartier registreren aan welke activiteït ze hadden deelgenomen en wat ze daar 
eventueel bij hadden gedronken. Het tijdbestedingsdagboek is voor zover bekend nooit eerder gebruikt voor de registratie wan drinkgedrag in het dagelijks leven. In hoofdstuk 2 is geconstateerd dat het dagboek als een betrouwbar en valide instrument ter registratie van zowel tijdbesteding als alcoholgebruik mag worden beschouwd.

De dagboekdata geven een gedetailleerd, specifiek en objectief beeld wan het gedrag tijdens een doorsnee week. Om wanuif deze specifieke gegevens te kunnen komen tot en beschrijving van de sociale drinkgewoonten in Nederland was een zekere vereenvoudiging vereist. Bij deze vereenwoudiging zijn een aantal empirische criteria gehanteerd. Hierbij is uitgegaan van de theoretische icleeen wit hoofdstuk 1 en is getracht de specificiteit van de gegevens zo min mogelijk te reduceren.

Sociale drinkgewoonten zijn per definitie normaal gedrag. Er is werondersteld dat de frequentie warmee een gedraging zich onder bepaalde omstandigheden voordoet de normaliteit wan dat gedrag weerspiegeld. Ten aanzien van de frequentie warmee drinkgedrag zich voordoet kunnen voor alle dagen van de week drie verschillende periodes worden onderscheiden. Ochtenden (06.00 uur tot 14.00 uur), middagen (14.00 uur tot 20.00 uur) en avonden (20.00 uur tot 06.00 uur). Drinkgedrag werd als normaal beschouwd wanneer het zich voordeed tijdens een periode wararin meer dan 5\% wan de populatie drinkt. Zondagochtend, alle middagen en alle avonden werden volgens dit criterium als normale tijden om te drinken gedefinieerd. Voor elk van deze periodes is per activiteit het aantal deelnemers en het aantal drinkers berekend. Wanneer $1 \%$ of meer van de totale populatie tijdens een periode bij een actiwiteit alcohol gebruikte werd het drinken bij die activiteit tijdens die periode als normaal gedrag, als een normale drinkgelegenheid beschouwd. Zo konden er voor mannen 195 en voor vrouwen 95 verschillende normale drinkgelegenheden worden onderscheiden.

ledere drinkgelegenheid is een unieke combinatie van dag van de week, tijdstip van de dag en activiteit. Per drinkgelegenheid is de kans op drinkgedrag berekend als het aantal mensen dat bij de betreffende combinatie van dag, tijd en activiteit dronk gedeeld door het aantal mensen dat er aan deelnam. Gelegenheden die alleen verschilden wat betreft dag van de week, en dus niet in activiteit, periode en kans op drinkgedrag, werden beschouwd als realisaties van drinkgedrag binnen dezelfde ideaal-typische omstandigheden. Deze omstandigheden zijn drinksituaties genoemd. Uiteindelijk zijn er aldus voor mannen 60 en voor vrouwen 34 verschillende drinksituaties gedefinieerd. Aan de hand van de kenmerken van deze drinksituaties zijn de sociale drinkgewoonten in Nederland beschreven.

Activiteit, dag(en) wan de week tijdstip van de dag zijn de objectieve kenmerken van drinksituaties. Bij vergelijking met resultaten van eerder onderzoek kumnen geen veranderingen in de aldus gekatakteriseende sociale drinkgewoonten in Nederland worden geconstateerd. Kort samengevat: in het weekend en tijdens de avonduren is alcoholgebruik gebruikelijker dan op weekdagen en 's middags. Dit blijkt zowel uit werschillen in het aantal activiteiten waarbij wordt gedronken als wit verschillen in de kans op drinkgedrag per activiteit tussen week- en weekenddagen of awonden en middagen. Met betrekking tot drinkgedrag begint het "natte" weekend op vrijdagmiddag en eindigt het zondagmiddag. Zondagavond onderscheid zich in dit opzicht niet van de avonden van maandag tot en met donderdag. Activiteiten waarbij de kans. op drinkgedrag hoog is zijn bezoek aan openbare drinkgelegenheden en visite. Een zeer groot deel van alle drank wordt thuis geconsumeerd ( $68 \%$ bij de mannen, $80 \%$ bij de vrowwen). De activiteit warbij absoluut het meest wordt gedronken is zowel voor mannen als voor vrouwen telewisie-kijken. 
In tegenstelling tot eerder onderzoek in Nederland zijn in deze studie alle mogelijke drinkgedragingen in het dagelijks leven geregistreerd. Gebleken is onder andere, dat er geen enkele activiteit is waarbij door niemand wordt gedronken. Verder is duidelijk gebleken dat een groot deel van de populatie in een doorsnee week alcohol gebruikt in situaties waarin dat sociaal niet normaal is. Bij de mannen wordt $13 \%$ en bij de vrouwen $19 \%$ van alle drank in abnormale situaties gebruikt.

De grens tussen normaal en abnormaal drinkgedrag is niet absoluut. Om 20 min mogelijk drinkgedrag van verdere analyse uit te sluiten is hier een minimaal criterium als afbakening gehanteerd. Dat heeft als gevolg gehad dat een aantal drinkgelegenheden waarvan mag worden betwijfeld of ze als sociale drinkgewoonten mogen worden gezien, als normaal drinkgedrag zijn gedefinieerd. Dit waren onder andere slapen op woensdag- of trijdagavond en persoonlijke verzorging op zaterdagavond. De kans op drinkgedrag is als kenmerk van drinksituaties gebruikt. De kans op drinkgedrag onder deze omstandigheden bleek extreem laag te zijn. Hierdloor kunnen dergelijke drinksituaties van andere drinksituaties worden onderscheiden.

Zoals gezegd is de kans op drinkgedrag in de situatie beschouwd als een reflectie van de mate van normaliteit van drinkgedrag in die situatie. De kans op drinkgedrag is hier het resultaat van het gedrag van alle deelnemers aan een drinksituatie. Uitgaande wan de stelling dat de meeste mensen zich het merendeel van de tijd conform de geldende verwachtingen of regels gedragen is deze kans beschouwd alls een reflectie van de beoordeling van de gepastheid van drinkgedrag. Waarschijnlijk is er een sterk verband tussen drinkgedrag en de sociale betekenis die een situatie voor een actor heeft. Verschillen in kans gaan samen met met objectieve kenmerken van situaties. Die variatie weerspiegeld het gemiddelde van de aan die situatie verleende betekenissen.

De aannames ten aanzien van de relatie tussen de interpretatie van situaties en het daadwerkelijk gerealiseerd gedrag kunnen alleen worden getoetst door naast het gedrag ook de perceptie van situaties door sociale actoren te meten. Uit een dergelijk onderzoek zou ook kunnen worden afgeleid in hoeverre de veelheid van situaties zoals hier gedefinieerd verder kan worden gereduceerd tot een kleiner aantal ideaal-typische situaties. Een vraag is welke kenmerken van situaties naast activiteit en temporele lokatie een rol spelen bij de definitie van ideaal-typische situaties en hoe belangrijk voor deze definitie verschillende aspecten ten opzichte wan elkaar zijn. Het is niet ondenkbaar dat sociale actoren bijvoorbeeld op een avond lezen, televisiekijken en relaxen en deze activiteiten tezamen als een en dezelfde ideaal-typische drinksituatie beschouwen. Het is daarnaast ook niet onaannemelijk dat eenzelfde objectieve situatie door verschillende mensen anders wordt beoordeeld. Voor de ene kan visite een gezellige reünie met vrienden of familie betekenen, terwijl het voor een ander een verplicht 'ritueel' kan zijn.

Omdat de drinksituaties zeer specifiek zijn omschreven mag bij een eventuele herhaling van dit onderzoek niet worden werwacht dat exact dezelfde situaties nalar voren zullen komen. Ook zullen er door toevalsvariaties, met name bij situaties waaraan slecht weinig mensen deelnemen, verschillen in kansen op drinkgedrag worden gevonden. Toch is er niet tot een minder specifieke omschrijving van drinksituaties, bijvoorbeeld door activiteiten samen te voegen of kleine maar significante verschillen in kans bij dezelfde activiteit op verschillende dagen te negeren, besloten. Bij de nu gehanteerde omschrijving kan er met een redelijke zekerheid van worden uitgegaan dat alle drinkgedrag in een drinksituatie als een zelfde sociale gewoonte mag worden gezien. 
Tevens kan er van worden uitgegaan dat alle drinkgedrag dat nu als abnormaal (minder dan $1 \%$ wan de populatie) gedefinieerd is ook als zodanig wordt beleefd. Een verdere samenvatting van het materiaal zonder gebruik te maken van toegevoegde informatie (zoals sociale betekenissen) zal die zekerheid reduceren.

Het gebruikte onderzoeksinstrument, het dagboek, zou achteraf beschouwd, op enkele punten kunnen worden verbeterd. Activiteitencategorieën die niet van belang zijn voor drinkgedrag (bijvoorbeeld individuele sport en teamsport) kunnen worden samengevoegd. Bij andere activiteiten zou een specifieker onderscheid kunnen worden gemaakt, hierbij moet met name aan een scheiding tussen wisite aan familie of vrienden en kennissen en visite wan familie of vrienden en kennissen worden gedacht. De rol wan gast verschilt waarschijnlijk meer van die van gastheer dan dat de rol van 'gast bij familie' van die van 'gast bij vrienden' verschilt. Ook zou het zeker zinvol zijn om respondenten per dag te laten aangeven in hoeverre ze die dag als een doorsnee dag in hun dagelijks leven beschouwen. Dit is vooral belangrijk wanneer individuen worden geclassificeerd op basis van hun gedrag tijdens de dagboekweek.

Verdergaande veranderingen zouden kunnen zijn om respondenten de interpretatie en evaluatie van situaties in termen van sociale betekenissen of het aanwezige gezelschap te laten rapporteren. Bij eventuele veranderingen van het onderzoeksinstrument moet er op worden gelet dat resultaten vergelijkbaar blijven met die van dit onderzoek. Alleen dan kunnen mogelijke ontwikkelingen in de sociale drinkgewoonten van de Nederlandse bevolking worden geconstateerd.

\section{Rollen en drinkgedrag}

Bij de beschrijving van de sociale drinkgewoonten was de situatie analyse-eenheid. Regelmatigheden in gedrag kunnen worden verklaard uit overeenkomsten tussen de situaties waarin dat gedrag plaatsvindt. Het begrip sociale gewoonte kan verklaren waarom ondanks de grote variatie aan mogelijk gepast gedrag, in vergelijkbare situaties steeds hetzelfde gedrag wordt vertoond.

Systematische verschillen in gedrag tussen individuen kunnen worden begrepen als resultaat van systematische of structurele verschillen in verwachtingen ten aanzien van gepast gedrag verbonden met kenmerken van die individuen. Dergelijke verwachtingen zijn rollen.

Drie typen rollen worden onderscheiden: statusrollen, positierollen en situatierollen.

Statusrollen biedlen een algemene gedragsoriëntatie die ook ten aanzien van alcoholgebruik tot verschillen tussen individuen kan leiden (Knibbe, 1984). In de literatuur (Gadourek, 1963; Sijlbing, 1978; Knibbe, 1984) worden de volgende structurele samenhangen tussen statusrollen en alcoholgebruik genoemd: manmen drinken meer dan vrouwen, de hogere sociale klassen drinken vaker matr matiger (minder per gelegenheid) dan de lagere sociale klassen, protestanten drinken minder dan mensen zonder religie of rooms-katholieken en dagelijks drinken komt het meest voor bij mensen van middelbare leeftijd terwijl periodiek veel drinken bij jongeren het meest voorkomt.

In de literatuur worden twee soorten hypothesen onderscheiden omtrent relaties tussen positierollen en alcoholgebruik (Winton et al, 1986). De zogenaamde 'leisure-time' hypothesen stellen dat verschillen in beschikbare tijd tot verschillen in drankgebruik kunnen leiden (Hammer en Vaglum, 1989; Ekerdt et al., 1987; Power, 1989; Shaw, 1980). Een tweede soort hypothesen veronderstelt een intensiever drankgebruik verbonden met het ontbreken van dan 
wel een teveel aan, structurerende positierollen. Deze categorie wan hypothesen wordt betiteld als de 'stress' hypothesen. Ze veronderstellen positieve werbanden tussen stress of spanningen en drankgebruik.

Er zijn geen onderzoeken bekend waarin de gelegenheid om te drinken is gemeten. Het is dan ook niet mogelijk om uit de literatuur af te leiden in hoeverre geconstateerde relaties tussen rollen en alcoholconsumptie het gevolg zijn van verschillen in gelegenheid om te drinken of van verschillen in intensiteit van drinkgedrag. De vaak veronderstelde verbanden tussen met name positierollen en de gelegenheid om te drinken zijn in overeenstemming met resultaten van onderzoek naar tijdbesteding. Uit dergelijk onderzoek (Knulst en Schoonderwoerd, 1983; Hill, 1985; Elchardus en van Rossem, 1985) blijkt dat het ontbreken van structurerende rollen samengaat met een grotere hoeveelheid vrije tijd. Alcoholgebruik komt in zulk onderzoek echter niet voor.

De dagboekdata scheppen de mogelijkheid om het onderscheid tussen gelegenheid om te drinken en intensiteit van drinkgedrag wel te maken. In hoofdstuk 4 is een model opgesteld dat de totstandkoming van drinkgedrag beschrijft. In dit model staat de gelegentheid on te drinken centraal. Er is een verband verondersteld tussen de gelegenheid om te drinken en de consumptie en er is een onderscheid gemaakt tussen factoren van invloed op de gelegenheid en factoren van invloed op de intensiteit van drinkgedrag gegeven de gelegenheid.

De gelegenheid om te drinken is geoperationaliseerd als de tijd besteed in drinksituaties. Natuurlijk is er (bijna) altijd een mogelijkheid om alcohol te gebruiken. Dat blijkt ook uit het relatief grote aantal respondenten dat tijdens de dagboekweek onder sociaal niet normale omstandigheden drinkt. Het begrip drinkgelegenheid impliceert een zekere uniformiteit van omstandigheden waarin wordt gedronken naar activiteit, dag van de week en tijdstip. De kenmerken van de situaties waarin de abnormale drinkgelegenheden worden gerealiseerd verschillen bijna per individu. Het drinken buiten drinksituaties staat geheel los van kenmerken van de situatie zoals hier gemeten. Daarom kan de gelegenheid om te drinken buiten drinksituaties, niet worden gemeten.

Omdat er geen redenen waren om aan te nemen dat verbanden tussen rollen en gelegenheid of verbanden tussen rollen en intensiteit van drinkgedrag in alle drinksituaties dezelfde richting zouden hebben is een onderscheid tussen verschillende drinksituaties gemaakt. Daar het aantal deelnemers per drinksituatie in de meeste gevallen te gering was om relaties tussen rollen en gelegenheid of intensiteit van drinkgedrag per drinksituatie afzonderlijk te onderzoeken zijn drie categorieën van drinksituaties gecreëerd. De kans op drinkgedrag is als indelingscriterium gehanteerd. Er is een onderscheid gemaakt tussen droge, medium en natte situaties.

Drie categorieën van hypothesen zijn geformuleerd: hypothesen betreffende relaties tussen rollen en de gelegenheid om te drinken, hypothesen betreffende relaties tussen gelegenheid om te drinken en consumptie en hypothesen betreffende relaties tussen rollen en de intensiteit van drinkgedrag.

Deze hypothesen zijn onderzocht door middel van analyses in deelpopulaties gedefinieerd natar leeftijd en geslacht. Een nadeel van het verdelen van de populatie en het onderscheiden van categorieën van drinksituaties is dat de gevarieerdheid van de resultaten het trekken van algemene conclusies bijna onmogelijk maakt. Daar staat tegenover dat de complexiteit van het drinkgedrag en de daaraan gerelateerde factoren in de resultaten goed tot uitdrukking komt. Bij de analyses van relaties tussen rollen en het drinkgedrag is het individu als analyse-eenheid gebruikt. 
De resultaten van eerder onderzoek naar relaties tussen rollen en alcoholgebruik zijn niet eenduidjg. Voor een deel kan dat worden verklaard door verschillen in wizze warop drinkgedrag wordt geoperationaliseerd (Ctawford et al., 1987; van der Horst 1988). Daarom zijn relaties tussen rollen en drinkgedrag in deze studie op verschillende manieren onderzocht. Relities tussen rollen en het al dan niet drinken bij deelname aan drinksituaties worden onderscheiden van relaties tussen rollen en de voor gelegenheid gecontroleerde consumptie van de drinkers binnen drinksituaties.

Een algemeen geldende conclusic is dat de tijdbesteding sterk samenhangt met het drankgebruk. Hoe meer tijd in drinksituaties wordt besteed hoe meer er in die situaties wordt gedronker. Dat geldt niet alleen woor de natte situaties, warin alloholgebruik als gedragsalternatief zeer prominent aanwezig is, maar zij het in iets mindere mate, ook voor de medium en croge situaties.

De expositie aan drinksituaties was de belangrijkste verklarende variabele van de consumptie in die situaties. Met name wat betreft de expositie aan natte situaties kan niet worden uitgesloten dat de centrale plats van het drinken in die situaties een belangrijk motief is om tijd in die situaties te besteden. Inspectie van de resultaten toont dat een aantal relaties tussen rollen (partner, scholier/student en sociale klasse) en de expositie aan natte situaties dezelfde richting heeft als verbanden tussen diezelfde rollen en de intensiteit van drinkgedrag.

In medium en droge drinksituaties moet het alcoholgebruik worden gezien als een bijkomstigheid, een toevallig resultaat wan de tijdbesteding, een sociale gewoonte. Desondanks zijn verbanden tussen de expositie aan deze situaties en de consumptie in die situaties zijn niet gering. Reden om ook factoren die met cleze expositie samenhangen in verklaringen van variaties in drinkgedrag te betrekken.

In bijna alle leeftijd-geslacht categorieen warin de rol van werkende voorkomt werden negatieve verbanden tussen werk en de tijd besteed in droge drinksituaties gevonden. Alleen bij jonge vrouwen is er geen significante samenhang tussen werk en de expositie aan droge drinksituaties. De categorie der droge drinksituaties bestaat voornamelijk uit situaties die op de middagen van weekdagen zijn gelokaliseerd. Uit onderzoek naar tijdbesteding is gebleken dat verschillen in tijdbesteding tussen werkenden en niet-werkenden zich met name op deze tijden voordoen.

Bij jonge mannen bleek dat werkenden gemiddeld meer tijd in medium natte situaties doorbrengen dan hun niet-werkende leeftijdsgenoten (scholieren/studenten en anderen). Daarin verschillen ze van de werkende mannen van middelbare leeftijd die minder tijd in medium drinksituaties besteden dan hun niet werkende leeftijdsgenoten.

In tegenstelling tot de negatieve verbanden met expositie aan droge drinksituaties bleek werk positiel samen te hangen met het aantal drinkende deelnemers (jonge mannen) en de voor expositie gecontroleerde consumptie (mannen tussen 25 en 54 jaar) in die situaties. Ook in andere situaties werden positieve verbanden tussen werk en alcoholgebruik gevonden. In medium situaties drinken werkende jonge mannen na controle voor expositie, meer dan hun niet werkende leeftijdsgenoten. In natte situaties is het aantal drinkende jonge vrouwen relatief groter onder de werkende dan onder de niet werkende deelneemsters. In medium situaties geldt hetzelfide bij de vrouwen van middelbare leeftijd.

Het drinkgedrag van mannen tussen 55 en 64 jaar hangt niet significant samen met de rol van werkende of gepensioneerde. Dit komt overeen met de resultaten van andere onderzoek (van 
der Horst, 1988; Ekerdt et al, 1987) maar yerschilt met resultaten gerapporteerd door Knibbe (1984).

Wanneer wordt gecontroleerd voor expositie of deelname an drinksituaties bljkt werk dus positief samen te hangen met alcoholgebruik. Dit is volstrekt in regenspraak met hypothesen 6 en 7.

Er moet rekening mee worden gehouden dat als verwachte verschillen in totas alcoholgebruik tussen werkenden en niet- werkenden worden gevonden dit waarschijnlijk meer een bijkomstig resultaat van verschillen in tijdbesteding dan een gevolg van stress of spanningen dan wel verlies van structuur in het dagelijks leven zal zijn. Verder kan niet worden ontkend dat werk stress met zich mee kan brengen. Om de 'stress' hypothesen grondig te toetsen dient 'stress' te worden gemeten en dienen effecten van 'stress' op drankgebruik gecontroleerd te worden voor de gelegenheid om te drinken.

Naast werk zijn ook de rollen van partner en verzorger van jonge kinderen als structurerend beschouwd. Deze rollen reduceren blijkens de literatuur over tijdbesteding ook de totale beschikbare (vrije-) tijd. De rol van partner hangt bij mannen tussen 25 en 54 jaar echter positief samen met de expositie aan medium drinksituaties en met de proportie drinkende deelnemers aan die situaties. Bij vrouwen van diezelfde leeftijd is er een positief verband tussen de rol van partner en het percentage drinkers onder de deelnemers aan droge en natte situaties. De blootstelling aan natte situaties (café-bezoek) van mannen tussen 25 en 54 jaar met partner is lager dan die van degenen zonder partner. Bij oudere vrouwen hangt de rol van partner negatief samen met de expositie aan medium situaties.

De rol van verzorger opwoeder beperkt de totale expositie aan drinksituaties van mannen en vrouwen tussen 25 en 54 jaar. Bij de vrouwen komt dit effect woort uit een geringere expositie aan medium situaties. Dit zijn met name 'uit-huis" situaties zoals visite en café-bezoek. Bij de mannen werden er in de afzonderlijke categorieën van drinksituaties geen significante effecten van de verzorgerrol geconstateerd. Bij jonge vrouwen lijkt de tijd doorgebracht in droge drinksituaties negatief samen te hangen met de rol van verzorgster. Met de consumptie variabelen hangt de verzorger/opvoederrol niet significant samen.

In deze studie zijn positierollen als belangrijkste factoren verbonden met drinkgedrag beschouwd, althans wanneer geslacht en leeftijd buiten beschouwing worden gelaten. De invloeden van statusrollen op de expositie aan drinksituaties zijn gecontroleerd voor invloeden van positierollen; samenhangen met consumptievariabelen zijn daarna ast ook gecont roleerd voor expositie. Effecten van sociale klasse werden net name bij mannen en vrouwen tussen 25 en 54 jaar gevonden. Deze deelpopulaties bevatien veruit de meeste respondenten en tevens het hoogst percentage drinkers. Bij mannen (25-54 jaar) bleek sociale klasse negatief samen te hangen met de expositie maar positief met de voor expositie gecontroleerde, consumptie in droge situaties. Bij deze categorie mannen hangt sociale klasse ook positief samen met de expositie aan en de proportie drinkende deelnemers in natte situaties. Ook bij mannen tussen 55 en 64 jaar is de proportie drinkende deelnemers het hoogst in de hogere klassen. Bij vrouwen van middelbare leeftijd zijn er negatieve verbanden tussen sociale klasse en zowel de expositie aan medium situaties als de voor expositie gecontroleerde consumptie in natte situaties. Bij dezelfde categorie vrouwen is er echter een positief verband tussen sociale klasse en de proportie drinkende deelnemers aan droge situaties. Jongere wrouwen uit de hogere klasser 
besteden minder tijd dan die uil de lagere klassen in zowel droge als medium drinksituaties. De verbanden tussen religie en expositie en consumptievariabelen zijn eenduidiger. Protestantisme hangt negatief samen met zowel expositie aan drinksituaties als proportie crinkende deelnemers en woor expositie gecontroleerde, consumptie in drinksituaties. In een aantal gevallen blijkt dat uit directe negatieve verbanden tussen protestantisme en de betreffende variabelen in andere gevallen uit positieve verbanden van 'geen religie' of roomskatholicisme met de betreffende variabelen.

Al met al bijkt dat er geen sprake is vain algemeen matigende effecten van structurerende positierollen op het drankgebruik.

De variaties in de verbanden tussen rollen en expositie enerzijds en intensiteit van drinkgedrag anderzijds en de variaties in de effecten binnen verschillende categorieën van drinksituaties zijn te groot om algemene hypothesen te hanteren. Een belangrijk resultaat van deze studie is, dat is aangetoond dat effecten van rollen op de expositie tegengesteld kunnen zijn aan die op de intensiteit van drinkgedrag en dat de effecten in verschillende categorieèn van situaties regengesteld kunnen zijn. Mogelijk is dit een van wan de verklaringen voor de inconsistentie van resultaten van onderzoeken waarin verschillende operationalisaties van drinkgedrag zijn gebruikt. Verschillende maten voor drinkgedrag kunnen tot verschillen in conclusies leiden en dit zal zeer waarschijnlijk afhankelijk zijn van de situaties waarin de daadwerkelijke verschillen in drinkgedrag zich voordoen. Verschillen in gedrag in droge situaties zullen eerder tot verschillen in scores voor frequentie leiden terwijl verschillen binnen natte situaties met name tot verschillen in scores voor kwantiteit per keer kunnen leiden.

In schema 7.1 worden de verschillende hypothesen betreffende rollen en expositie, expositie en consumptie en rollen en consumtie alsmede de uitkomsten van de analyses nog eens op een rijtje gezet. 


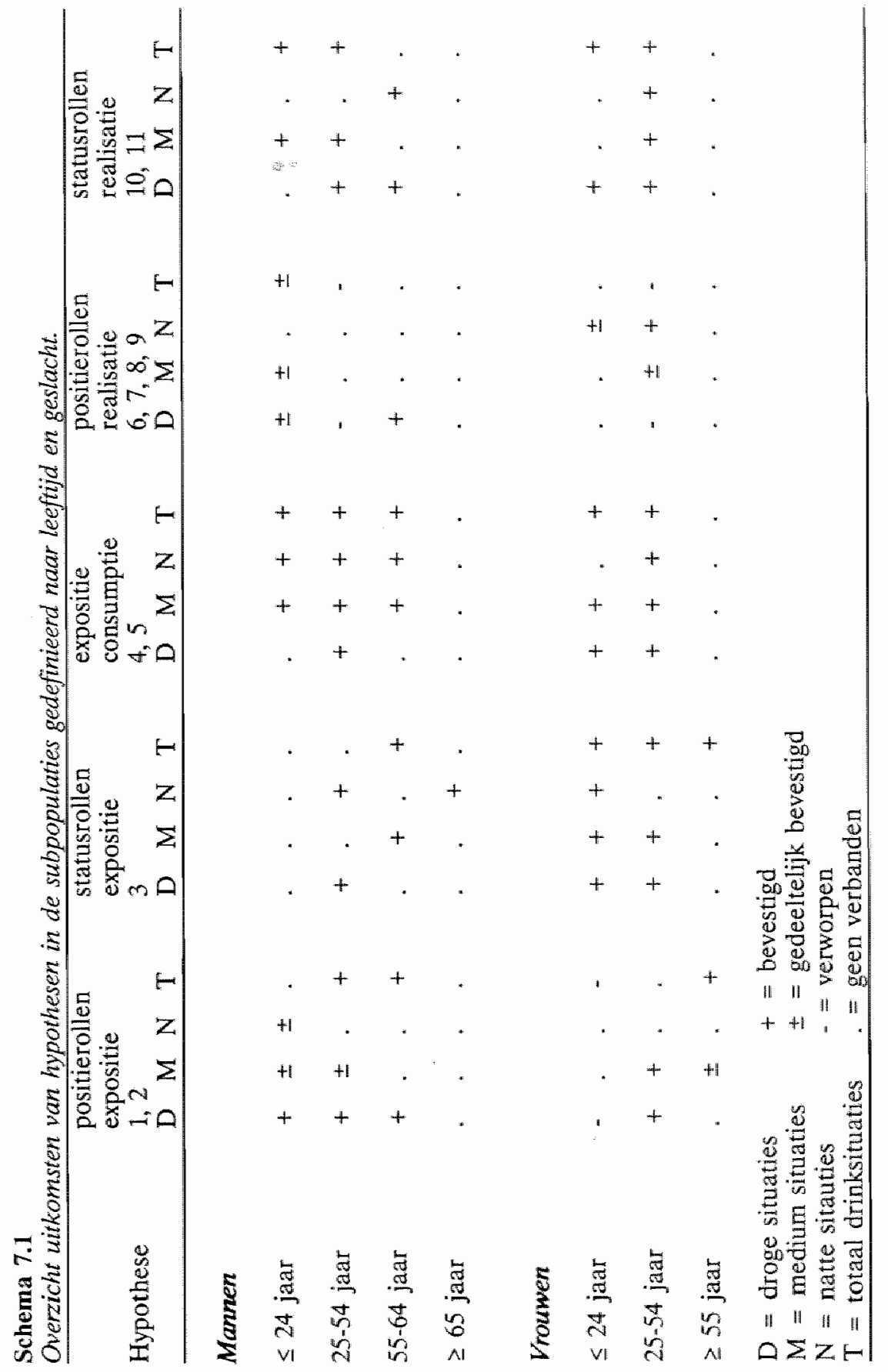




\section{Verschillen in drinkgedrag naar consumptieniveau}

Naast relaties tussen rollen, expositie en consumptie zijn verschillen in drinkgedrag tussen lichte, matige en zware drinkers en verbanden tussen rollen en de zwaarte wan het drinkgedrag tijdens de dagboekweek onderzocht. De categorieën der lichte, matige en zware drinkers verschillen zonder twijfel wat betreft beoordeling van de gepastheid van alcoholgebruik in situaties. De vraag die in hoofdstuk 3 werd gesteld was thoe dergelijke verschillen in het drinkgedrag tot uiting komen. Deze vraag is onder andere van belang omdat uit verschillen tussen lichte, matige en zware drinkers aanwijzingen kunnen worden afgeleid omtrent het proces van intensivering van drinkgedrag.

Verschillen tussen lichte, matige en zware drinkers zijn zowel van kwantitatieve als van kwalitatieve aard. Zware drinkers drinken in alle categorieën drinksituaties vaker en meer dan lichte drinkers. De verschillen in drinkgedrag zijn het meest uitgesproken in droge drinksituaties. Het percentage zware drinkers dlat in droge situaties drinkt is veel groter dan het percentage lichte drinkers dat dit doet. Ook het gemiddelde aandeel (per drinker) van de consumptie in droge situaties in de totale consumptie is bij zware drinkers groter dan bij lichte en matige drinkers. Uit deze resultaten is afgeleid dat intensivering van drankgebruik op indiwidueel niveau resultaat is van of leidt tot, een verandering in cle beoordeling van drinksituaties. Zware drinkers voegen met name het drinken in droge situaties toe aan hun individuele repertoire van drinkgewoonten. Bij wrouwen is het gemiddelde aandeel (per drinker) van de consumptie in abnormale situaties in de totale consumptie bij lichte drinkers het grootst. De totale drinkfrequentie van deze lichte drinkers is echter zo laag (1-2 gelegenheden per week) clat voor degenen die een abnormale drinkgelegenheid realiseren dit bijna noodzakelijk een groot deel van hun totale drankgebruik is. Bij mannen is er geen verschil in het aandeel van de consumptie in abnormale situaties in de totale consumptie van lichte, medium en zware drinkers. De uitbreiding van het drankgebruik beperkt zich dus voornamelijk tot sociale drinkgewoonten. Dit suggereert mogelijkheden om screeningsinstrumenten te ontwikkelen waarmee zware drinkers kunnen worden opgespoord. Zulke instrumenten zouden moeten bestaan uit een lijst van drinksituaties. Respondenten (of patiënten) zouden per situatie kunnen aangeven of ze weleens alcohol in die situatie gebruiken. Per definitie zijn drinksituaties normale omstandigheden om in te drinken. Wellicht dat mogelijke effecten van sociale wenselijkheid hierdoor worden gereduceerd. Degenen die in relatief veel droge situaties zeggen te drinken behoren mogelijk tot een risicogroep wat betreft hun drinkgedrag. Om daadwerkelijk een dergelijk screeningsinstrument te ontwikkelen is verder onderzoek nat de schaalbaarheid van drinksituaties vereist.

Ondat het drinken centraal aandachtspunt in deze studie was zijn de drinksituaties in deze studie in categorieern verdeeld op basis van de kans op drinkgedrag in die situaties. Andere indelingen van situaties zouden ten aanzien van bepaalde vragen wellicht eenduidigere resultaten opleveren. Wanneer bijvoorbeeld effecten van rollen als partner of verzorger op de blootstelling aan drinksituaties het centrale aandachtspunt zijn, is een verdleling wan situaties in binnenshuisbuitenshuis misschien beter. Zo kunnen er voor verschillende vraagstellingen verschillende indelingen worden gehanteerd. De hier gepresenteerde resultaten tonen aan dat er grote verschillen tussen situaties kunnen zijn. Bij indelingen van situaties in categorieên moet daar altijd rekening mee worden gehouden. 


\section{Rollen en consumptieniveau}

Tussen rollen en de zwaarte van het drankgebruik werden slechts enkele significante verbanden gevonden. Bij werkende vrouwen is het aandeel zware drinkers relatief hoog. Bij mannen komen er relatief veel zware drinkers voor bij de werkenden en degenen met partner. Bij mannen is er ook een significant verband tussen de combinatie van positierollen en de verdeling wan de populatie in lichte, medium en zware drinkers. De categorie mannen zonder structurerende rollen bevat relatief veel lichte en weinig zware drinkers. Al deze relaties zijn in tegenspraak met hypothese 14. In deze hypothese werden net als in de hypothesen 1,6 en 7 negatieve verbanden tussen structurerende rollen en de alcoholconsumptie verondersteld. De resultaten zijn echter in overeenstemming met de resultaten van de andere analyses in dit proesschrift.

Van de statusrollen bleek alleen leeftijd significant met de zwaarte van het drinkgedrag samen te hangen. Mensen van middelbare leeftijd (35-45 jaar) zijn relatief vaak als zware drinkers geclassificeerd, jongeren ( $\leq 24$ jaar) en ouderen ( $\geq 64$ jaar) zijn relatief vaak als lichte drinkers of niet-drinkers tijdens de dagboekweek geclassificeerd.

De indeling van drinkers in de categorieën licht, matig of zwaar is gebaseerd op het gedrag tijdens de dagboekweek. Op individueel niveau behoeft deze indeling niet representatief te zijn voor het doorsnee gedrag. Het gedrag kan per week variëren, positie- en statusrollen zijn daarentegen permanente kenmerken van individuen. Mogelijk kan dit een verklaring zijn voor het ontbreken van verbanden. Een andere verklaring voor het geringe aantal significante verbanden kan gevonden worden in de resultaten van de multiple regressie analyses. Effecten van rollen op de expositie waren in een aantal gevallen tegengesteld aan die op de consumptie. Verder waren er tegengestelde verbanden van rollen in de verschillende categorieën van drinksituaties of leeftijdscategorieën. Mogelijk heffen dergelijke tegengestelde verbanden elkaar op. Dit pleit voor het onderscheiden van factoren van invloed op de expositie en factoren van invloed op de consumptie en verschillende categorieën van drinksituaties.

\section{Structurerende rollen en drinkgedrag}

De samenstelling van de leeftijdscategorieën wat betreft positierollen verschillt nogal. Bij de jongeren zijn werkenden vergeleken met scholieren/studenten, bij de oudere mannen (55-64 jaar) met vervroegd gepensioneerden, bij de vrouwen tussen 25 en 54 jaar met huisvrouwen. Positieve effecten van werk mogen daarom niet zonder meer geünterpreteerd worden als negatieve effecten van werkloosheid. Desondanks zijn de geconstateerde verbanden lijnrecht in tegenspraak met de onder de algemene noemer 'stress' hypothesen vervatte veronderstellingen omtrent positieve relaties tussen werkloosheid en drankgebruik.

De hier geconstateerde verbanden tussen de rollen van partner en werkende en het alcoholgebruik zijn gedeeltelijk tegengesteld aan die welke Knibbe et al. (1987) rapporteren. Omdat het onderzoek van Knibbe ook in Nederland is uitgevoerd zal op deze tegenstelling worden ingegaan. Knibbe constateert negatieve verbanden tussen het aantal structurerende positierolien en zowel het aantal zware als het aantal lichte drinkers bij mannen. Ook afzonderlijk hangen werk en partner negatief samen met het aantal zware en het aantal lichte drinkers. Een reden waarom er volgens Knibbe meer zware drinkers zouden zijn in categorieën van de populatie waar structurerende rollen ontbreken is dat situatierollen waarin alcoholgebruik plaatsvindt worden geïntensiveerd. Deze redenering lijkt niet op te gaan. Het ontbreken van werk leidt weliswaar tot een grotere expositie aan drinksituaties, werk is echter positief gerelateerd aan de intensiteit waarmee binnen die situaties wordt gedronken. Ook het 
bekleden van de rol van partner blijkt bij mannen en vrouwen tussen 25 en 54 jaar positief samen te hangen met de intensiteit van drinkgedrag.

In hoofdstuk 6 is vastgesteld dat het aantal lichte drinkers relatief het grootst is in categorieen zonder structurerende positierolen, in tegenstelling tot de resultaten van Knibbe blikt het aantal 2ware drinker in deze categorietn echter het laagst te zijn. Ook de biil mannen geconstateerde relaties tussen hel antal zware, matige of lichte drinkers en de rollen van partner en werkende afonderlijk zijn tegengesteld as die welke Knibbe rapporteert. Een mogelikke reden hiervoor zou het verschil in definitie wan zwaar drinken kunnen ziln. Knibbe hanteert een extremere definitie van zwaar drinken dan die welke in deze studie is gebruikt. Het is mogelijk dat alleen de allerzwarste drunkers owervertegenwoordigd zijn in categorieën zonder structurerende rollen en dat deze relatie bil een bredere definitie van zwaar drinken niet naar voren komt. Dit kan echter niet verklaren warom er bij cle werkende en bij degenen met een partner relatief meer zware drinkers worden gewonden:

Een andere mogelikke verklaring voor de verschillen tussen de hier gepresenteerde resultaten en de resultaten van het onderzoek van Knibbe (1984) is dat dit laatste betrekking had op ZuidLimburg en Rotterdam terwijl dit onderzoek geheel Nederland betrof. Knibbe constateert verschillen in de verbanden tussen rollen en drinkgedrag in Rotterdam en die in Zuid-Limburg. Structurerende rollen blijken met name in Rotterdam een beschermende invloed te hebben.

Een antal positieve verbanden tussen structurerende positierollen en expositie of consumptievariabellen kan worden begrepen als samenhangend met het hebben van een eigen gezin: De effecten van partner op de expositie en consumptie wan mannen in medium situaties en van vrouwen in droge situaties duiden hierop. De categorie droge situaties van de vrouwen en de categorie medium situaties van de mannen bestaan voor een belangrijk deel uit situaties in de huiselijke kring. Wanneer er vanuit gegaan wordt dat jonge werkende mannen meer dan hun studerende leeftijdsgenoten de levensfase van een eigen gezin hebben bereikt kan dit ook de grotere expositie wan de jonge werkende mannen aan medium situaties verklaren. Structurerende effecten van een eigen gezin mogen voor alcoholgebruik eerder als een risico dan als een bescherming worden beschouwd.

Een geheel andere verklaring van de verschillen in resultaten zou kunnen zijn dat de samenstelling wan de populatie werklozen in deze studie mogelijk verschilt van die in de studie van Knibbe. Tussen 1981 en 1985 is het aantal werklozen en de gemiddelde duur van de werkloosheid toegenomen. Ten aanzien van relaties met alcoholgebruik worden verschillende fases in de werkloosheid onderscheiden (Winton et al, 1986). In eerste instantie zou er een positief effect van werkloosheid op drinkgedrag optreden volgens redenen die al eerder zijn uiteengezet: een grotere hoeveelheid vrije tijd en een beleving daarvan als 'holiday mood'. Waineer er geen baan wordt gevonden zou dit vakantiegevoel na verloop van tijd verdwijnen en er zouden financiele problemen ontstaan. Hierdoor zou dan volgens Winton et al. (1986) het drankgebrük afnemen. Uit onze resultaten blijkt dat werklozen meer tijd besteden in droge drinksituaties maar bij gelijke blootstelling minder drinken dan werkenden. Wellicht hebben de droge situaties voor de werklozen hun betekenis van wrije tijd die ze voor de werkenden wel. hebben, verloren. Met name bij langdurig werklozen kan dit worden verwacht.

Zowel de onderzoekspopulatie van Knibbe et al. (1987) als de hier gebruikte populatie bevatten te weinig werkiozen om dergelijke effecten te onderzoeken.

Een representatieve steekproef uit de Nederlandse bevolking met een omvang als die in deze 
studie, is voor het simultaan onderzoeken van verbanden tussen alle relewante positierollen en alcoholgebruik niet de meest geschikte onderzoekspopulatie. Het aantal werklozen en part-time werkenden is daarvoor te gering en de variatie in positierollen over leeftijdscategorieen is daarvoor te groot. Een beperking van de onderzoekspopulatie tot bepaalde leeftijdscategorieën (bijvoorbeeld 25 tot 54 jaar) en een relatieve oververtegenwoordiging van verschillende categorieën van niet-werkenden zou, zeker wanneer naast het concrete gedrag ook de beoordeling van situaties wordt gemeten, verdergaande conclusies mogelijk maken.

\section{Toekomstige ontwikkelingen}

Meer vrije tijd leidt niet zonder meer tot een grotere expositie aan drinksituaties. Meer tijd in drinksituaties leidt echter wel tot een hogere consumptie. Dit al eerder genoemde, resultaat duidt erop dat veranderingen in tijdbesteding grote consequenties voor het drankgebruik kunnen hebben. Op individueel niveau hangen zulke veranderingen samen met veranderingen in positierollen. Echter ook op populatieniveau doen zich veranderingen in tijdbesteding voor. In toekomstscenario's tot uitdrukking gebrachte verwachtingen schetsen ontwikkelingen die zullen leiden tot een samenleving waarin de tijd flexibeler zal zijn verdeeld en mensen meer tijd ter beschikking zullen hebben (van Houten, 1985; Spruijt, 1981). Er zal gedurende een groter deel van de dag gewerkt worden (arbeidsduurverlenging) maar individuen zullen minder tijd aan werk besteden. Wat dergelijke ontwikkellingen zullen betekenen voor het clrankgebruik is afhankelijk van de wijze waarop een grotere hoeveelheid vrije tijd ter beschikking komt en vatn de betekenis die mensen aan de 'nieuwe' vrije tijd zullen geven. Verlenging van het weekend met een extra vrije dag zal zeer waarschijnlijk leiden tot meer drankgebruik. Wanneer extra vrije dagen gespreid worden over de week zal dit waarschijnlijk minder drastische consequenties woor het alcoholgebruik hebben omdat de vrije dagen qua sociale betekenis mogelijk als werkdagen zullen worden beleefd.

Wanneer temporele normen vervagen ten gevolge van vervaging van de grenzen tussen werktijcl en wrije-tijd (denk ook aan ontwikkelingen als tele-werken) zullen ook de temporele verwachtingen omtrent drinkgedrag veranderen. De afbakening tussen geschikte en minder geschikte tijden om te drinken zal vervagen. Of een dergelijke afbakening tot meer of minder drinkgedrag zou leiden is moeilijk te zeggen. In het voorafgaande zijn enkele suggesties voor verder onderzoek gedaan waardoor ook dergelijke vragen zouden kunnen worden beantwoord. Tenslotte moet worden opgemerkt dat met het materiaal dat in deze studie is gebruikt nog vele interessante vragen kunnen worden onderzocht. Onderzoeken naar relaties tussen de soort drank en situatiekenmerken, relaties tussen het gedrag op verschillende dagen, de bovengenoemde verbanden tussen probleemdrinken en het gebruik van alcohol in droge situaties, de uitwisselbaarheid van alcoholhoudende en andere dranken en mogelijke verschillen tussen het drinkgedrag in doorsnee weken, zoals hier beschreven en het gedrag rond de jaarwisseling zijn slechts enkele mogelijkheden. 


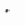




\section{Summary}

In this study, the drinking habits of the Dutch population are described.

In chapter one, theoretical explanations of regularities in behavior and systenatic differences in behavior between individuals are presented. Drinking is described as an act. The smallest meaningful unit of behavior is the activity, acts are parts of activities. All behavior occurs in situations. The way situations are perceived and interpreted in terms of rules for adequate behavior are determined by and form the basis of the social structure actors are part of. In our society the social order has a strict mathematical temporal character. Temporal 'signs' guide social behavior. Time of day and day of the week are social facts that direct "judgements' of adequacy of behavior.

A large part of all drinking behavior may be considered as a social habit (Knibbe, 1984; Gadourek, 1963). Social habits are shared semi-automatic responses to stimuli in social situations. Both primary activity and temporal characteristics of situations are regarded as stimuli that are related to the occurrence of drinking in situations.

Regularities in drinking behavior may be explained as a result of similarities in the situations in which people participate. Systematic differences between people can be understood as the result of systematic differences in expectations about adequate behavior. Such systematic variations in expectations are roles.

Three types of roles may be distinguished: status roles, positional roles and situational roles. Status roles are ascribed. They consist of expectations based on characteristics of social identity such as sex, age, social class or religion. Status roles offer general behavioral orientations which may direct behavior in all kinds of situations. Positions are places in social systems like the family or working organization. Positional roles are acquired. To keep a position, actors have to fulfill the requirements of the positional role. This implies a certain degree of regularity in behavior, fixed timing and duration of activities. Positional roles structure everyday life.

Situational roles are expectations of adequate behavior within specifie situations. Situational roles may be more oriented towards objective characteristics of situations (traffic) or towards relationships with other people (guest, friend). Situational roles only apply to the concrete actual situation in which an actor is present.

Like habits, situational roles can only explain differences in behavior within specific situations. Structural differences in drinking behavior between individuals can be explained by positional and status roles. Such roles partly determine in which situations actors will participate in the course of everyday life and thus partly determine the opportunity to drink. A second way in which these roles may be related to alcohol consumption is through their relations with the perception of the adequacy of drinking within situations.

In chapter two, the instrument used in this study to gather the data is described. Since it wats concluded in chapter one that drinking is determined by situations and that temporal aspects of situations and primary activity are of importance, an instrument measuring time-use seemed appropriate. Several time-budget instruments are compared: observations, activity checklists and time-budget diaries. Diaries appear to be highly reliable and valid instruments to measure timeuse. To measure timing and duration of activities and acts in large populations, diaries are the only viable method.

However, time-budget diaries have never been used before to record alcohol-use. With regard to time-use and the use of alcohol, measures recording actual behavior in a short recent period 
appear to yield the most valid and reliable results. Some measures of actuall drinking behavior are described: the weekly recall or retrospective diary, the time-line method, the last occasions method and the alcohol diary. The time budget diary combines the advantages of these methods. It does not require respondents to summarize their behavior. It offers respondents a frame (time and activity) for memorizing drinking and the time between the actual behavior and recording it is one day at the most. Furthermore, the diary provides detailed information about the circumstances (activity, time) in which drinking occurs. It enables the examination of the extent to which such circumstances occur in everyday life without drinking taking place. Thus the 'normality' of drinking in specific circumstances can be assessed.

The data used in this study were acquired by means of a time-budget survey $(n=916)$ performed in 1985. A national. random sample of respondents (16-70 years) were asked to record their primary activity and use of beverages during seven consecutive days. For every quarter of an hour an entry in the diary was made. Data were gathered in severall periods spread over the year. The response rate was $72 \%$.

In chapter three the social drinking habits of the Dutch population are described. First a graph of the number of drinkers per hour was constructed. Based on this graph three periods in the day were distinguished: Mornings (06.00hrs to $14.00 \mathrm{hrs}$ ), Afternoons (14.00hrs to 20.00hrs) and Evenungs (20.00hrs to 06.00hrs). Drinking was considered to be normal only during periods in which more than $5 \%$ of the population actually drink. For each period and for men and women separately, the activities with which drinking may be considered socially appropriate were determined. All activities with which at least $1 \%$ of the population reported alcohol-use during a specific period were considered as circumstances defining normal drinking occasions. For all possible normal drinking occasions the probability that drinking occurs was computed as the number of drinkers in specific circumstances (dlay, time and activity) divided by the number of people participating in these circumstances. Occasions only differing in the day of the week, thus not in time of day, primary activity and probability of drinking, were considered as drinking behavior in the same typical drinking situation.

For men 60 and for women 34 different drinking situations were defined. The characteristics of these situations were used to describe the social drinking habits in the Dutch population.

In the Netherlands drinking is more common in the evening than in the afternoon. Drinking in the morning is only common on Sunday. Drinking is also more common on weekenddays than on weekdays. Temporal variations in the 'normality' of drinking result in more activities combined with drinking that are located in the evenings or in weekenddays. These temporat variations are also reflected in higher probabilities of drinking with specific activities in the evening as compared to the afternoon or on weekenddays as compared to weekdays. Since probability is computed for participants in drinking situations only, patterns in time-use do not determine these temporal patterns in the probability that drinking occurs. With regard to drinking Sunday evening does not belong to the 'wet' weekend. Sunday evening does not differ from the evenings of Monday through Thursday. The 'drinking weekend' starts on Friday evening and ends on Sunday afternoon. Activities characterized by high probabilities that drinking occurs are visiting public drinking places and visiting friends or relatives on Friday or Saturday evening. There are no activities with which no drinking at all occurs. 
Based on the probability of alcohol consumption three categories of drinking situmtions were defined: Dry situations $(.05 \leq p \leq .20)$, medium situations $(20<p<.50)$ and wet situations $(\mathrm{P} \geq 50)$. A fourth category of drimking behavior covers all consumption that does not occur in drinking situations, namely abnomal drinking.

Two hypotheses were formulated with regard to differences between drinkers. The first hypothesis states that differences between light, moderate and heavy drinkers are only of a quantitative nature. Though heavy drinkers use more alcohol, differences between them and light or moderate drinkers should be the same in all kinds of drinking situations. "The second hypothesis supposes qualitative differences between drinkers. Heavy drinkers drink more in specific siltuations or drink in other situations than light or moderate drinkers. These hypotheses were tested by comparing the drinking behavior of light, moderate and heavy drinkers within the four different categories of drinking situations. Per category of drinking situations frequency of drinking quantity per occasion, number of drinkers and the share of the consumption within that category in the total consumption were computed. Differences between light, moderate and heavy drinkers appear to be both of a quantitative and a qualitative nature. Heavy drinkers drink more often and more within all categories of drinking situations. The differences between heavy, moderate and light drinkers are most pronounced within the dry drinking situations in which probability that drinking occurs is low. It was concluded that heavy drinkers add new (dry) situations to their individual range of drinking situations. Intensified drinking leads to or is it result of a broader range of situations in which the drinker considers allohol-use to be appropriate.

Since there are many normal drinking situations in the Netherlands, heavy drinking can not easily be detected. Heavy drinkers can easily restrict their drinking to socially acceptable drinking situations. The detection of heavy drinking is even more difficult because differences in drinking behavior within drinking situations (quantity per occasion) are small (statistically not significant) and because drinking in inappropriate siltuations (situations in which almost nobody drinks) is not uncommon. More than half of the population (men and women) drink in an inappropriate situation at least once during the diary week.

In chapter four, relations between roles and drinking as presented in the literature are examined. Hypotheses are formulated, variables are made operational and techniques of analysis are described.

A model describing the way in which alcohol-use is realized is presented. The correlation between opportunity to drink and consumption is central in this model. Factors influencing opportunity to drink should be distinguished from factors influencing the intensity of drinking given the opportunity.

The alcohol-literature and literature on time-use were the basis for a set of hypotheses about relations between positional and status roles and opportunity and intensity of drinking.

Opportunity to drink was measured as the time spent in drinking situations. It was supposed that structuring positional roles (work, partner, parent) reduce the time spent in drinking situations (hypothesis 1). It was also supposed that work should specifically reduce the time spent in dry situations (hypothesis 2), since these situations are mainly located on working times. When controlling for positional roles some influence of status roles on opportunity to drink will remain (hypothesis 3). Furthermore the assumption was posed that the more time people spend in drinking situations, the higher their alcohol consumption will be (hypothesis 4 ). This relation 
between opportunity and consumption should be stronger in situations that are characterized by a higher probability that drinking owcurs (hypothesis 5).

These first five hypotheses represent the general class of "leisure-time' bypotheses as reported in alcohol-literature. Another generally used class of hypotheses explaining differences in drinking behavior are the so called 'stress hypotheses'. This kind of explanation presupposes higher alcohol consumption as a result of intensifted drinking (for example as a result of stress or tensions). In the literature no reports of measures of opportunity to drink were found. Thus it cannot be determined whether differences in consumption are the result of differences in opportunity ar differences in intensity. In this study the difference between opportunity and intensity was made.

It was supposed that the proportion of drinking participants in drinking situation should be higher in categories of respondents lacking structuring positional roles (hypothesis 6). Also, the intensity of drinking should be higher in those categories of the population (hypothesis 7). Based on differences between heavy, moderate and light drinkers and differences between men and women as described in chapter three, it was supposed that relations between intensity of drinking and roles should be most pronounced in dry situations (hypothesis 8 and 9). Also status roles should be related to intensity of drinking and proportion of drinking participants (hypotheses 10 and 11 ).

If there are general effects of roles on opportunity and intensity this should also be reflected in relations between roles and the distribution of light, medium and heavy drinkers. It was supposed that in categories of the population lacking structuring roles there would be relatively more heavy drinkers (hypothesis 12) and less people that do not drink during the diary week (hypothesis 14). Status roles will also be related to the distribution of non-drinkers, light, moder te and heavy drinkers in the population (hypotheses 13 and 15).

Hypotheses 1 through 10 were tested by means of logit and multiple regression analyses. The logit analyses were used to analyze the effect of roles on the number of drinking participants in drinking situations. The multiple regression analyses were used to analyze relations between roles and opportunity to drink, relations between opportunity and consumption and relations between roles and consumption controlling for opportunity (intensity). Because there is a curvelinear relation between alcohol-use and age and because positional roles are not evenly distributed across the different sex and age categories, all logit- and multiple regression analyses were performed separately in different categories of respondents defined by sex and age.

Relations between roles and the distribution of non-drinkers, light moderate and heavy drinkers (hypotheses 12 through 15 ) were analyzed by means of chi-square tests.

In chapter five results of the analyses with regard to opportunity to drink and the relation between opportunity and consumption are presented.

The general hypothesis that structuring roles are negatively related to opportunity to drink can not be confirmed in all cases. Work is indeed negatively related to the time men $(\leq 24,25-54)$ and women (25-55) spend in dry situations and the time men (25-54) spend in medium situations. However, young working men spend more time in dry situation than their age companions that go to school or college. Older housewives spend more time in medium situations than the other older women. Partner is positively related to the time men (25-54) spend in medium situations but at the same time this role is negatively related to the time these men spend in wet situations. Among men the total time spent in drinking situations is not 
related to the role of partner. Among older women, those with a partiner spend less time in medium drinking situations.

Although, in none of the categories of drinking situations significant relations were found anong men, taking care of little children is negatively related to the total time men between 25 and 54 years old spend in drinking situations. Young women taking care of little children on average spend more time in dry situations. Women between 25 and 54 years old with little children spend less time in medium situations than their age companions who do not have little children. Both among men and women status role variables did explain some of the variance in exposure to drinking situations after controlling for positional roles (hypothesis 3). Social class was negatively related to the time middle-aged men spend in dry situations but positively related to the time they spend in wet situations. Among women social class whis negatively related to the time spent in dry situations $(\leq 24)$ and medium situations ( $\leq 24$ and $24-54$ ). Protestantism is negatively related to time spent in drinking situations. Indirectly through positive effects of no religion on the time spent in wet situations (men 25-54) or Roman-Catholicism on the time spent in medium (men 55-64) and wet situations (men $\geq 65$ ). Directly through negative relation between Protestantism and the time women spend in wet situations $(\leq 24)$ or medium situations (25-54).

Exposition to drinking situations is positively related to consumption in those situations (hypothesis 4). The more time people spend in drinking situations, the higher their alcoholconsumption in those situations. With the exception of the younger women, the strength of this correlation increases with the wetness of the situations. In some cases no correlations were found. This can be explained either by the small number of drinkers (older men and women) or by the assumption that alcohol-use is not a prominent behavioral option in dry situations (men $\leq 24$ and 55-64) and thus time spent in these situations is not significantly related to the consumption in these situations. Also the total time spent in drinking situations is moderately related to total consumption within drinking situations.

In chapter six, results of analyses concerning relations between roles and intensity of drinking are described. Drinking was made operational in three ways: as the number of drinking participant in categories of drinking situations, as the consumption of drinkers within categorles of drinking situations and as the total consumption-level during the diary week.

Work (men $\leq 24$ ) and having a partner (men $(25-54)$ are positively related to the proportion of drinking participants in dry and medium situations. Among young women work is positively related to the consumption in wet situations. Also the proportion of drinking working women (25-54) in medium situations is higher than that among housewives of this age.

The role of partner is positively related to the proportion of drinking participants in dry situations and in wet situations (men 25-54). Among women (25-54) the role of partnet is positively related to the proportion of drinkers in dry situations.

Thus all results are contrary to the expectation formulated in hyporhesis 6 . The proportion of drinking participants in drinking is higher in categories of the population with structuring roles. Status roles do explain some of the variance in the proportion of drinking participants in drinking situations after controlling for positional roles (hypothesis 10). Among Protestant men, the proportion of drinking participants in dry situations is relatively low. Among women the proportion of drinking participants is relatively high among those without a religious 
denomination. Sociall class is positively related to the proportion of drinking participants in wet situations (men 25-54 and 55-64) and dry situations (women 25-54).

Hypothesis 7 must be rejected in several cases. Relations between roles and consumption after controlling for exposition were interpreted as relations between roles and intensity of drinking. Work is positively related to the intensity of drinking of younger men (medium situations) and men between 25 and 54 (dry situations). Also among women between 25 and 54 the consumption in dry situation controlled for exposition is positively related to work. The role of partner is negatively related to intensity of drinking in dry situations (men 55-64).

Hypothesis 11 supposes relations between status roles and intensity of drinking, after controlling for exposition and positional roles. Social class is indeed positively related to the consumption in wet situations (men 25-54). It is negatively related to the intensity of drinking in wet situations among women 25 between 54 years old. Among younger women $(\leq 24)$ social class is negatively related to total controlled consumption.

Religion is also related to intensity of drinking. Intensity of drinking is lower among Protestants. This can be concluded from the negative effect of Protestantism on the consumption in medium situations (men $\leq 24,25-54$ ) or dry situations (women $\leq 24$ ) and the positive effects of no religion on the consumption of women between 25 and 54 in dry situations.

Though there are relations between roles and consumption, the variable explaining most of the variance in consumption in drinking situations is the exposition to these situations. Specifically in wet situations, almost no effects of roles on the consumption remain after controlling for exposition. This confirms hypothesis 9.

The third way in which drinking was made operational was through the total consumption-level in the diary week. The population can be divided in non-drinkers, light, moderate and heavy drinkers. Among working men and men with partners, as compared to those lacking these structuring roles, relatively more heavy and less light drinkers or non-drinkers were found. In the male population the proportion of light drinkers is largest in the category without any structuring roles.

Thus also hypothesis 12 and 14 have to be rejected. There are no negative relations between structuring roles and consumption level during the diary week. The only status role variable significantly related to the distribution of light, moderate and heavy drinkers was age. Among the middle-aged (35-44, 45-54) relatively more heavy and less light drinkers were found. Among the young $(\leq 24)$ and the old $(\geq 65)$ relatively more light and less heavy drinkers were found. The number of people that do not drink during the diary week is also relatively high among the younger and the older men.

With regard to social class and religion no significant relations with total consumption level were detected. Hypotheses 13 an 15 must be rejected.

Chapter seven contains a summary of this study as well as some general conclusions and remarks.

It is argued that the likelihood of drinking within drinking situations, is probably stronger related to the meaning social actors give to these situations than to the objective characteristics of these situations. Furthermore, it is concluded that only through studies into the meanings of situations the large number of different drinking situations as described in this study, may be reduced to fewer typical drinking situations without running the risk of oversimplifying the social drinking 
habits in the Netherlands.

An important conclusion of this study is that there are few general effects of roles on drinking. Influences of roles on opportumity to drink must be distinguished from influences on intensity of drinking and effects of roles on opportunity or intensity within different categories of drinking situations must also be distinguished.

In contrast to generally held expectations, structuring roles (work, partner) seem to be positively related to intensity of drinking in drinking situations. With regard to the positive effects of work on intensity of drinking in dry situations, it is argued that these sittuations may be experienced more as leisure time by workers than by (especially long-term) unemployed people. The positive effects of unemployment on drinking as (sometimes) reported in the literature probably are more a coincidental result of differences in time-use than a result of tensions, stress or lack of structure in everyday life.

Positive effects of the role of partner were found in situations that are mainly family/home oriented. Having a partner seems to be more of a risk than a protection against drinking in situations like watching television in the evening or sociall contacts with family members.

A general population sample as large as the one used in this study is not really suited for studying relations between drinking and structuring roles. The relative number of unemployed in the population is too small while variations of positional roles across age-categories are too large. Oversampling of different categories of non-working people and restricting the population to specific age categories (preferably 25-55) as well as measuring social meanings of drinking situations will probably enable more thorough conclusions.

Finally, possible future development and effects of changes in time-use on drinking are described. Several authors predict that in the future, people will work less and time will be organized more flexibly. It is highly likely that a prolonged weekend, by an extrin day off per week or per two weeks, will lead to heavier drinking. If extra free days are spread across the week, they will not be experienced the same way and effects on drinking will be probably be less rigorous. Flexible temporal organization of everyday life will result in less str"ict norms or expectations regarding appropriate (drinking) behavior. Whether this will lead to more or less alcohol consumption remains unclear. With regard to these questions, studies on the way people give meaning to socilal situations, especially in reference to drinking, might provide very useful information. 


\section{Literatuurlijst}

ARFKEN, C.L. Temporal patterns of alcohol consumption in the United States. Alcoholism: Clinical and Experimental Research, 12, 1, pp. 137-142, 1988.

As. D. Studies of time-use: problems and prospects. Acta Sociologica, 21, 2, pp. 125 $141,1978$.

BIE DE, S.E. Standaardvragen 1987. Rijksuniversiteit te Leiden, Leiden, 1978.

BLOK-VAN DER VOORT, E.H. Vakantie nader bekeken. Rijksuniversiteit Leiden, Leiden, 1977.

CAHALAN, D., CISIN, I.H., CROSSLEY, H.M. American drinking practices. Rutger Centre of Alcohol Studies, New Brunswick, N.J., 1969.

CONVERSE, P. Time budgets. In: International Encyclopedia of the Social Sciences, 16, MacMillan, New York, 1968.

CRAWFORD, A., PLANT, M.A., KREITMAN, N., LATCHAM, R.W. Unemployment and drinking behavior: some data from a general population survey of alcohol use. British Journal of Addiction, 82, pp. 1007-1016, 1987.

ELCHARDUS, M. Werktijdverkorting, kwaliteit van de arbeid en sociale betekenissen van de tijd. In: E. Scholliers en P. Scholliers (eds.). Werktijd en werktijdverkorting, pp. 131-153, Centrum voor hedendaagse sociale geschiedenis, Brussel, 1983.

ELCHARDUS, M. Het sociale substraat wan de tijd. Tijdschrift voor Sociologie, 6, 4, pp. 317-353, 1985.

ELCHARDUS, M., ROSSEM, VAN R. Werkloosheid en verzorgende tijdsbesteding. Centrum voor Sociologie, Brussel, 1985.

ELCHARDUS, M., GLORIEUX, I. De tijd als zingever. Tijdschrift voor Sociologie, 8,4 , pp. 53-87, 1987.

ELLIOTT, D., COSPER, R. The time-budget study of tavern-going: a validation. Journal of Studies on Alcohol, 43, 3, pp. 397-403, 1982.

EKERDT, D.J., DE LABRY, L.O., GLYNN, R.J., DAVIS, R.W., Change in drinking behaviors with retirement: findings from the normative aging study. Journal of Studies on Alcohol, 50, 4, pp. 347-353, 1987.

ENHUS, E, GLORIEUX, I., ROSSEM, VAN R. Tijdsbesteding en sociale isolatie bij werklozen. Centrum voor Sociologie, Brussel, 1985. 
GADOUREK, I. Riskante gewoonten en zorg woor eigen welzajin. Wolters, Groningen, 1963.

GELOOVEN VAN, R.M.W., DIEDERIKS, J.P.M., DROP, M.A., KNIBBE, R.A. Typical drinking situations: a first analysis. Paper presented at the meeting of the Alcohol Epidemiology Section of the International Council on Alcohol and Addictions, Aix-en-Provence, France, 1987.

GELOOVEN VAN, R.M.W., DIEDERIKS, J.P.M., DROP, M.A., KNIBBE, R.A. Health and everyday life: how to measure structure of everyday life. Paper presented at the Second Congress of the European Society of Medical Sociology, Zagreb, Yugoslavia, 1988.

GELOOVEN VAN, R.M.W., DIEDERIKS, J.P.M., DROP, M.A., KNIBBE, R.A. Drinking situations in everyday life. Paper presented at the meeting of the Alcohol Epidemiology Section of the International Council on Alcohol an Addictions, Maastricht, the Netherlands, 1989.

GERHARDT, U. Rollenanalyse als kritische Soziologie. Luchterhand Verlag, Berlin, 1971.

GIDDENS, A., The constitution of society. Polity Press, Cambridge, 1984.

GIDDENS, A., Sociology. Polity Press, Cambridge, 1989.

GLORIEUX, I. Werkloosheid en sociale zingeving, resultaten van een tijdsbudget onderzoek. In: C.J.M. Corver, M. Elchardus (eds.). Sociologisch en Antropologisch Jaarboek, Reeks van het Tijdschrift woor Sociologie, Brussel, 1989.

GLYNN, R.J., DE LABRY, L.O., HOU, D.M. Alcohol consumption, type A behavior and demographic variables, results from the normative aging study. American Journal of Epidemiology, 127, 2, pp. 310-320, 1988.

GUILFORD, J.P. Fundamental statistics in psychology and education. McGraw-Hill Book Company, New York, 1965.

HAMMER, T., VAGLUM, P. The increase in alcohol consumption among women: a phenomenom related to accessibility or stress? A general popullation survey. British Journal of Addiction, 84, pp. 767-775, 1989.

HARVEY, A.S., SZALAI, A., ELLIOTT, D.H., STONE, P.J., CLARK, S.M. Time budget research. An ISSC workbook in comparative analysis. Campus Verlag, Frankfurt New York, 1984.

HAWORTH, J.T., EVANS, S.T. Meaningful activity and unemployment. In: D. Fryer, P. Ullah (eds.). Unemployed people, Social and psychological perspectives. Open University Press, Philedelphia 1987. 
HILL, M.S. Patterns of time use. In: F.T. Juster en F.P. Stafford (eds.). Time, goods, and well-being. University of Michigan, Ann Arbor, 1985.

HORST VAN DER, F.G.E.M. Gezondheid en niet werken. Rijksuniversiteit Limburg. Maastricht, 1988.

HOUTEN VAN, H.J. De toekomst van de tijd. Op weg naar een samenhangend tijdbeleid. Giordano Bruno, Amersfoort, 1985.

JAHODA, M. Time, a social psychological perspective. In M. Young en T. Schuller (eds.). The rliythms of society, Routledge, London, 1988.

JUSTER, F.T. Conceptual and methodological issues involved in the measurement of time. In: F.T. Juster en F.P. Stafford (eds.). Time, goods, and wellbeing. University of Michigan, Ann Arbor, 1985.

JUSTER, F.T. The validity and quality of time use estimates obtained from recall diaries. In: F.T. Juster en F.P. Stafford (eds.). Time, goods, and wellbeing. University of Michigan, Ann Arbor, 1985.

KNIBBE, R.A. Probleemdrinken in Limburg. Rijksuniversiteit Limburg, Maastricht, 1982.

KNIBBE, R.A. Van gangbaar tot problematisch drankgebruik. Rijksuniversiteit Limburg, Maastricht, 1984.

KNIBBE, R.A., DROP, M.J., VAN REEK, J., SAENGER, G. The development of alcoholconsumption in the Netherlands: 1958-1981. British Journal of Addiction, 80, pp. 411-419, 1985.

KNIBBE, R.A., DROP, M.J., MUYTJENS, A. Correlates of stages in the progression from everyday drinking to problematic drinking. Social Science and Medicine, 124, 5, pp. 463-473, 1987.

KNULST, W., SCHOONDERWOERD, L. Waar blijft de tijd. Sociale en Culturele Studies-4, Sociaal en Cultureel Planbureau, Staatsuitgeverij, 's Gravenhage, 1983.

LANDES, D.S. Revolution in time. Clocks and the making of the modern world. The Belknap Press of Harvard University Press, Cambridge, 1983.

LEMMENS, P.H.H.M. Het Ledermann-model nader bezien. Rijksuniversiteit Limburg, Maastricht, 1987.

LEMMENS, P.H.H.M., KNIBBE, R.A., TAN, F. Weekly recall and diary estimates of alcohol consumption in a general population survey. Journal of Studies on Alcohol, 49, 2, pp. 131-135, 1988. 
LEMMENS, P.H.H.M., TAN, F., KNLBBE, R.A. Bias due to non-respons in a Dutch survey on alcohol consumption. British Journal of Addiction, 83, pp. $1069-1077,1988$.

McKENNA, S.P., McEWAN, J. Employment and health. In: D. Fryer, P. Ullah (eds.). Unemployed people, Social and psychological perspectives, Open University Press, Philedelphia, 1987.

MIDDLETON FILLMORE, $K$. Prevalence, incidence and chronicity of drinking patterns and problems among men as a function of age: a longitudinal and cohort analysis. British Journal of Addiction, 82, pp. 77-83, 1987.

NORUSIS, M.J. Advanced statistics guide. SPSSx McGraw-Hill Book Company, New York, 1985.

PHILIPSEN, H., KNIBBE, R.A., VAN REEK, J., Alcohol consumption in the Netherlands as a social phenomenom. In: R.J. Hermus (ed.). Alcohol, health and society, pp. 53-70, TNO, Zeist, 1983.

PHILIPSEN, $H_{.}$Maatschappij en verslawing. Cahiers Biowetenschappen en Maatschappij, 3, pp. 25-31, 1976.

PIETERSON, M. (ed.) Het technisch labyrinth, Boom, Meppel, 1981.

POÏKOLAÏNEN, K., KÄRKKÄINEN, P. Diary gives more accurate information about alcohol consumption than questionnaire. Drug and Alcohol Dependence, 11, pp. 209-216, 1983.

POWER, C. Employment and drinking in early adulthood: a longitudinal perspective. Paper presented at the meeting of the Alcohol Epidemiology Section of the International Council on Alcohol and Addictions, Maastricht, the Netherlands, 1989.

PRONOVOST, G. The sociology of time. Current Sociology, 37, 3, Sage Publications, 1989.

REDMAN, S., SANSON-FISHER, R.W., WILKINSON, C., FAHEY, P.P., GIBBERD, R.W. Agreement between two measures of alcohol consumption. Journal of Studies on Alcohol, 48, 2, 1987.

REEK VAN, J., KNIBBE, R.A., DROP, M.J. Ontwikkelingen in alcoholgebruik in Nederland tussen 1958 en 1981. Tijdschrift voor Sociale Gezondheidszorg, 61, pp. 954-959, 1983.

REESE II, W., KATOVITCH, M.A. Untimely acts: extending the interactionist conception of deviance. The Sociological Quarterly, 30, 2, pp. 159$184,1989$. 
ROBINSON, J.P. The validity and reliability of diaries versus alternative time-use measures. In: F.T. Juster en F.P. Stafford (eds.). Time, goods, and well-being. Uniwersity of Michigan, Ann Arbor, 1985.

ROBINSON, J.P. Time diary evidence about the social psychology of everyday life. In: J.E. McGrath (ed.). The social psychology of time, new perspectives. Sage Publications Inc., Newbury Park, 1988.

ROOM, R, Measuring alcohol consumption in the U.S.: methods and rationales. Paper presented at the meeting of the Alcohol Epidemiology Section of the International Institute on the Prevention and Treatment of Alcohol problems, Rome, Italy, 1985.

SCHEUCH, E.K., The time-budget interview. In: A. Szalai (ed.) The use of time. Mouton, Den Haag, 1972.

SHAW, S. The causes of increasing drinking problems amongst women: a general etiological theory. In: Camberwell Council on Alcoholism: Women \& A.cohol pp. 1-40, Travistock Publications, London, 1980.

SCHIPPERS, G.M. Alcoholgebruik en alcoholgerelateerde problematiek. Swets en Zeitlinger bv, Lisse, 1981.

SIJLBING, G. Drink- en Rookgewoonten. SWOAD, Amsterdam. 1978.

SIMPURA, J. Drinking: an ignored leisure activity, Journal of Leisure Research, 17, 3, pp. 200-211, 1985.

SIMPURA, J. Comparison of indices of alcoholconsumption in the Finnish 1984 drinking habits survey data. The Drinking and Drug Practices Surveyor, 22, pp. 3-10, 1988.

SIMPURA, J. A typical autumn week's drinking. In: J. Simpura (ed.). Finnish drinking habits, The Finnish Foundation for Alcohol Studies, 35, Gummurus Oy, Jyväskylä, 1987.

SOBELL, L.C., SOBELL, M.B., LEO, G.I., CANCILLA, A. Reliability of a timeline method: assesing normal drinkers' reports of recent drinking and a comparative evaluation across several populations. British Journal of Addiction, 83, pp. 392-402, 1988.

SOROKIN, P.A., BERGER, C.Q. Time budgets of human behavior. Harvard University Press, Cambridge, 1939.

SPRUIJT, A.P. Vrije tijd en vrije tijdsgedrag: een alternatief. In L. Rademaker (ed.) Sociale kaart van Nederland 2: toekomstperspectieven en alternatieven, Het Spectrum, Utrecht, 1981. 
STOOP, I.A.L., OUDHOF, J. Methoden van tijdsbestedingsonderzoek, verslag van een proefonderzoek. Bijdrage voor de Vlaams-Nederlandse studiedagen voor Sociologie en Antropologie, Antwerpen, 1988.

SZALAI, A. What is time budget research. In: A.S. Harvey, a. Szalai, D.H. Elliott, P.J. Stone, S.M. Clark, Time budget research. An ISSC workbook in comparative analysis. Campus Verlag, Frankfurt New York, 1984.

VOLLPICELLI, J.R. Uncontrollable events and alcohol drinking. British Journal of Addiction, 82, pp. 381-392, 1987.

DeVRIES, M.W. Investigating mental disorders in their natural setting. The Journal of Nervous and Mental Disease, 175, 9, pp. 509-513, 1987.

WEISS, W. Learning about uses of alcohol in a wet culture. The Drinking and Drug Practices Surveyor, 20, pp. 3-6, 1985.

WESTERLAAK, J.M., KROPMAN, J.A., COLLARIS, J.W.M. Beroepenklapper. Instituut voor Toegepaste Sociologie. Nijmegen, 1975.

WILKS, J., CALLAN, V.J. Expectations about appropriate drinking context: comparison of parents, adolescents and best friends. British Journal of Addiction, 83, pp. 1055-1062, 1988.

WINTON, M., HEATHER, N., ROBERTSON, I. Effects of unemploymenty on drinking behavior: a review of the relevant evidence. The International Journal of Addictions, 21, 12, pp. 1261-1283, 1986.

YOUNG, M. The metronomic society. Natural rhythms and human time tables. Harvard University Press, Cambridge, Massachusetts, 1988.

ZERUBAVEL, E. Patterns of time in hospital life. The University of Chicago Press, Chicago, 1979.

ZERUBAVEL, E Hidden rhythms: schedules and calanders in social life. The University of Chicago Press, Chicago, 1984. 
Bijlage 2.1

Een bladzidde uit het daghoek

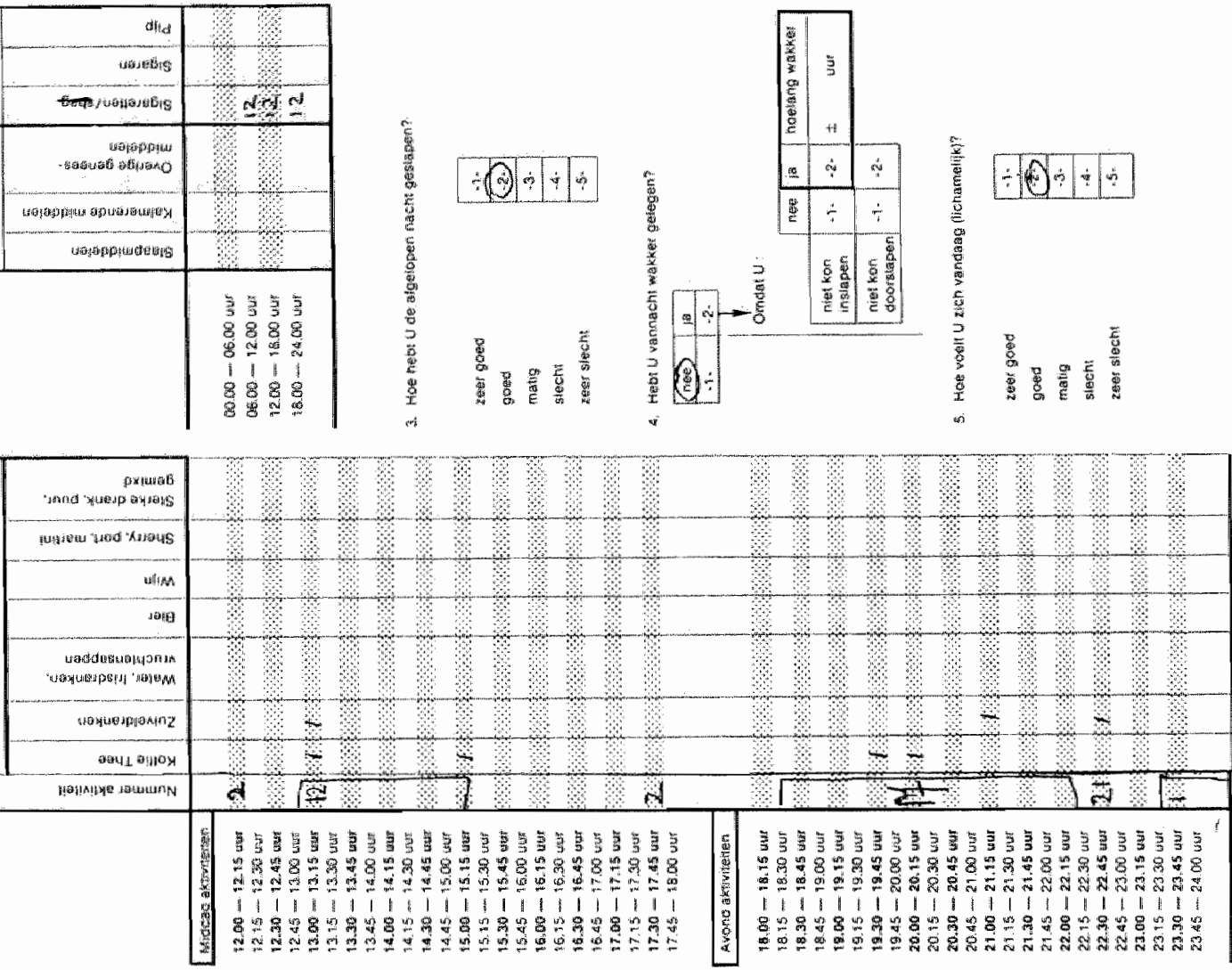

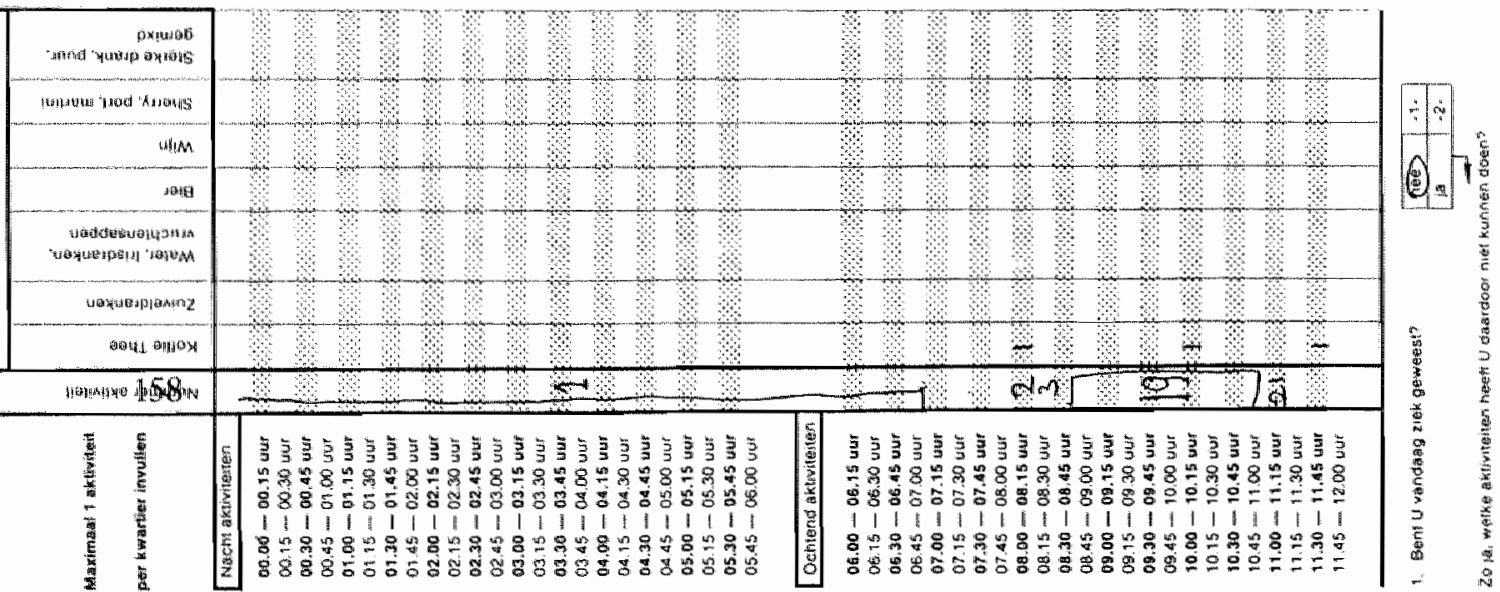




\section{Bijlage 2.2}

De activiteitencategorieën en daarbij behorende toeliching

1. slapen

2. eten

3. lichamelijke en geestelijke verzorging

4. betaald werk

5. muishoudelijk werk

6. verzorging opwoeding en begeleiding van kinderen en andere huisgenoten

7. dagopleiding volgen/nascholing vorming

8. kerkgang en andere activiteiten in verband met levensbeschouwing

9. organisatorische activiteiten in het kader van vereniging, kerk, politiek, school, buurt, gemeente; of andere vormen van belangenbehartiging

10. sportbeoefening in teamverband

11. individuele sportbeoefening

12. deelname aan het verenigingsleven

13. vrijwilligerswerk/hulpverlening

14. bezoek aan kantine van sportclub

15. bezoek aan sociëteit of buurthuis

16. bezoek aan café, restaurant, disco en dergelijke

17. bezoek aan/van familie: telefonisch kontakt met familie

18. bezoek aan/van vrienden en kennissen; telefonisch kontakt met vrienden en kennissen

19. kontakt met huisgenoten

20. andere vormen van uitgaan

21. karweitjes aan en rondom het huis; reparatie, onderhoud van goederen

22. vissen, wandelen, fietsen uitstapjes

23. hobby's

24. radio, t.v., thuis muziek luisteren

25. ontspannen, luieren, niets doen

26. lezen

27. anders 


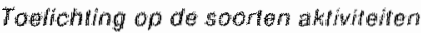

1. duje overdag, nachtrust, fush of bed hovden in werband met ziekte

2. madifgen hapjes lusendoor

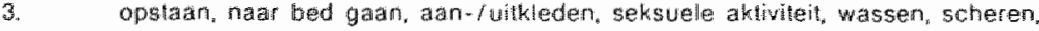
make-up anbrengen, douchen, naar thohl gaan bezoek arts, masseur, therapqut, logopedist, pedicure, kapper etcetera inklusief hel wervoer wan hus naar werk en wervoer tidens thel werk

5. inklusiel boodschappen, posthantoor, bark, gemeentehuis, en dergeithe en het vervoer dall nodig is wor thuishoudelikg akniveiten; teletonsch kontakt met instanties

6. hleronder vall ook werzorging vanwege zigkte of handicap van éen wain de huiggenoten

7. inklustef hot wervoer, huiswerk en andere bezigheden voor school

6. bijwonen van bijeenkomsten, diskussiegroepen en dergelihte

9. bijworbee pollteke orgarisaties, wakorganisaties, sociale arganisalies, ondernemimgsraden, wijkradem, ouderraad van een school en dergelikke

10. teamsporten zoais voetbal, volleybal, handbal, baskelbal

11. Sporten glis zwermen, trmmen, bewegen op muziek, lumen en sporten wat maar éen hegenspeter is, zoals taleltennis, judo wallen onder individuele sport onder andere ochlondgymnastiek

12. veremiging voor muzick, dans, loneel, katlen en dergelinke (geen sport)

13. hulp axn anderen dan huisgenoten ziekenbezoek, bejaardenzorg en dergellike

14. spreekl wor zich

15. leugdsociëteit, bejaarden sociëteit, studentensociëleit, buurthuis, socièlet wor axbeidsongeschiklen, voorzower socièteit niet in een cate of restaurant wordt. geholiden

$16 / 17 /$ bedoeld wordt hier de tijd die U bij anderen op bezoek bent (inklusief de reistijd) of

18. anderen bil: $U$ op bezoek zijn en warbij thet sociale kontakt hel belangritkste is. Indien het zo is dat tijidens het bezoek van of aan anderen nog andere dingen gedaan zinn, bifwoorbeeld siamen wandelen, knulselen, leren dan moel U deze aktiviteit en niot thet bezoek noteren.

Bent U langere tijd bij iemand op bezoek, een weekend bijvoorbeeld, dan moet U: ook bezigheden zoals eten, silapen, lichamellike verzorging noteren en niev het bezoek

19. bedowid word hiter hel konlakt mel huisgenoten warbij hel sociale aspek het belangrifken is

20. bezankan bioscoop. schouwburg. museum sportwedstriden/ of anciere evene. menten

21. opknappen en onderhouden gen geblikvoorwerpen zoals auto, stofzuiger.

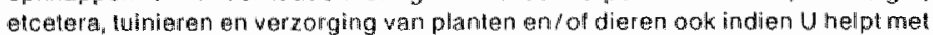
cleze aktivileiten

$22 / 23$ trobbies, zoals knutseler, handwezken, naaien, puzzelen, denksport, sichilderen, kgkenen, boetserent, musiceren, schrijven (dagboek bihhouden)

24. spreskt woor zich

25. spreekt woor zich

26. zoals boeken, krant, brochures en dergelijke

27. als Uw bezigheden onder geen wain de gemoende soorten akiliteiten wallen vult dan ciffer 27 in 


\section{Bijlage 3.1}

\section{Drinkgelegenheden waarbij meer dan $1 \%$ van de populatie alcohol gebruikt}

\section{Tabel 1}

Aantal drinkers $(D N)$ en aantal deelnemers $(N)$ per activiteit op zondagochtend (06.00-14.00 uur), bij mannen en vrouwen.

\begin{tabular}{lrrrrr}
\hline & \multicolumn{2}{c}{ Mannen } & \multicolumn{2}{c}{ Vrouwen } \\
Activiteit & DN & N & \multicolumn{2}{c}{ DN } & N \\
\hline & 12 & 453 & 6 & 390 \\
Eten & 25 & 104 & 18 & 110 \\
Visite familie & 12 & 54 & & \\
Visite kennissen & 6 & 80 & & \\
Socialle Contacten & 9 & 99 & & \\
Massa media & 7 & 168 & & \\
Relax & 6 & 98 & & \\
Lezen & & & & \\
\end{tabular}




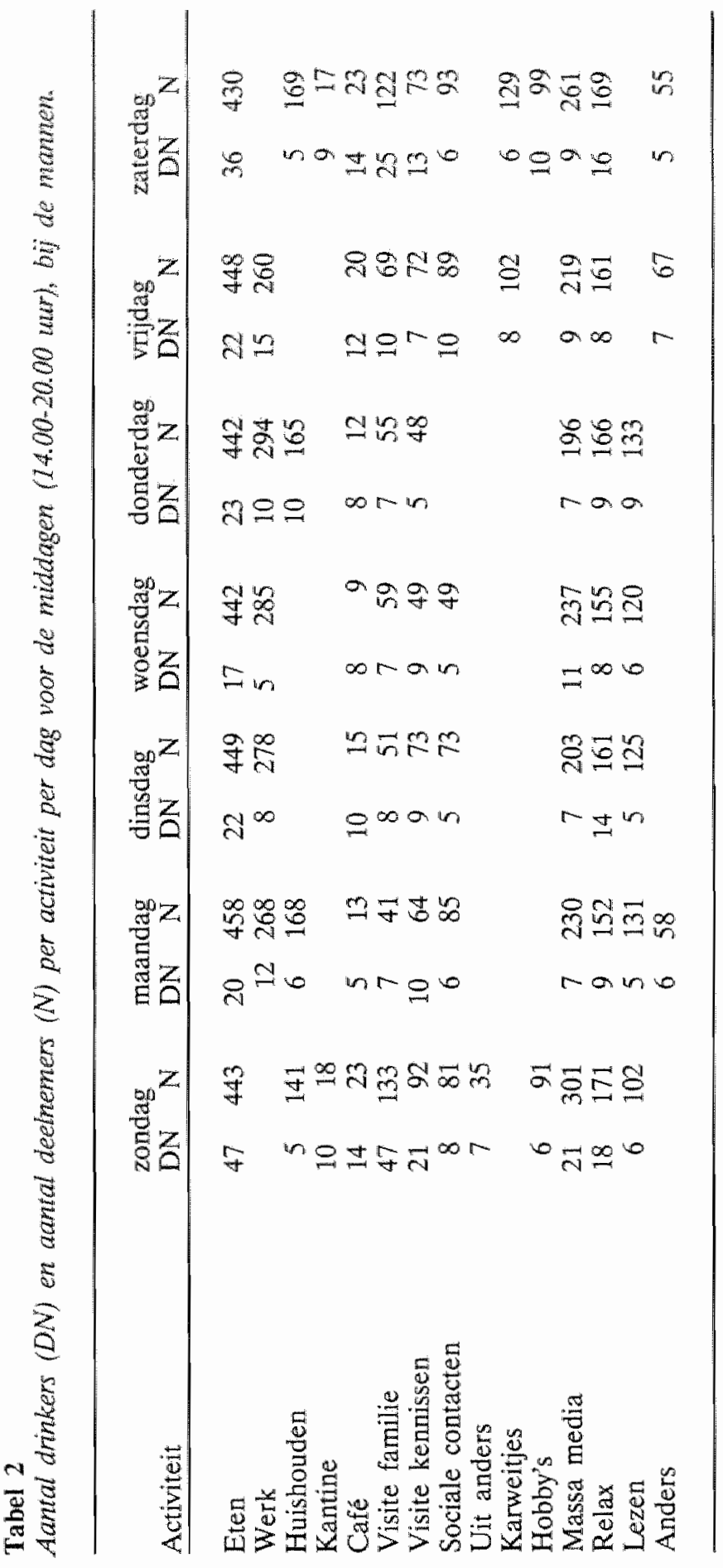




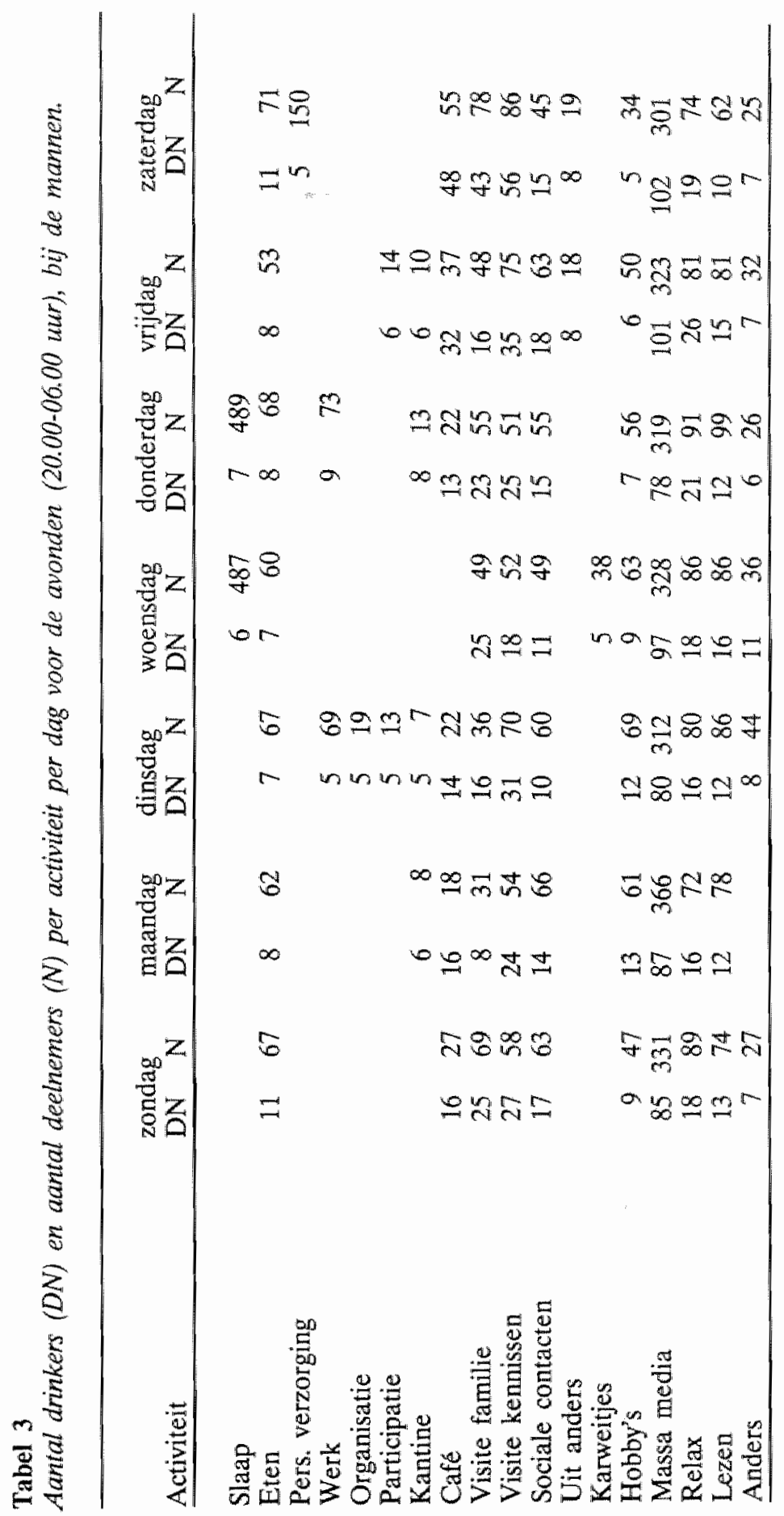




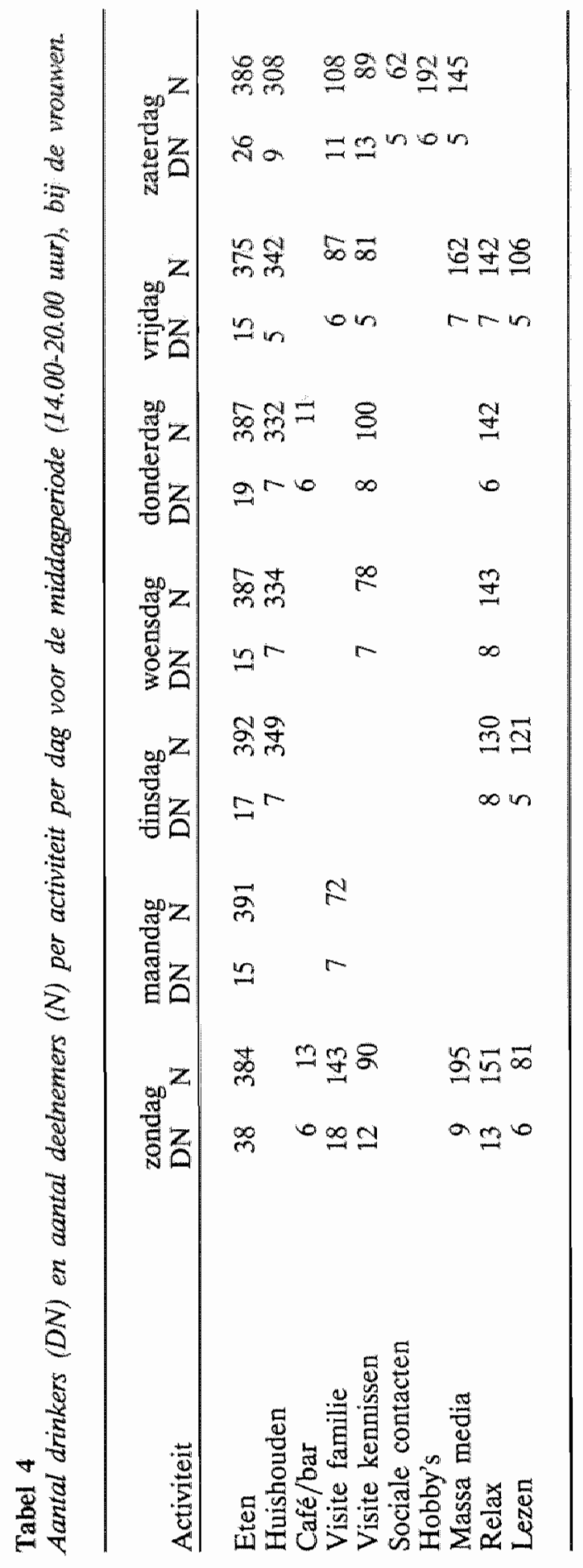




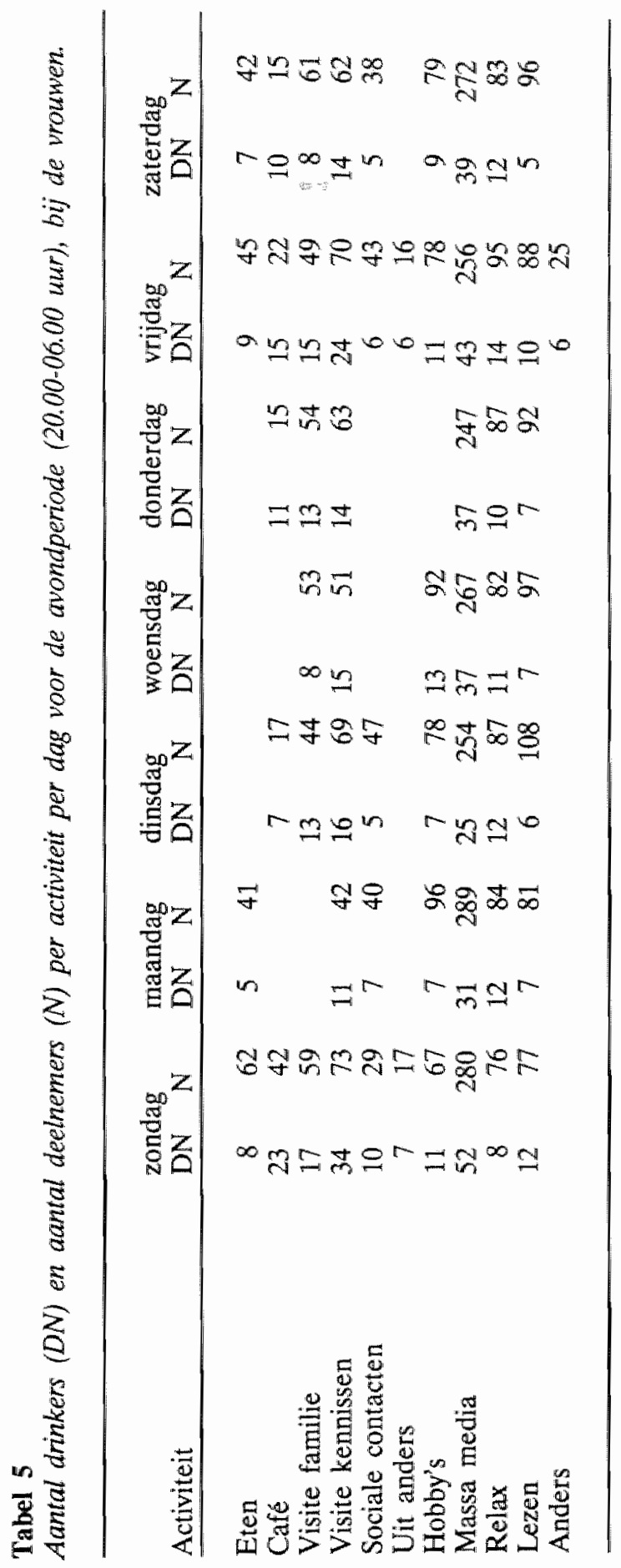




\section{Bijlage 3.2 \\ Frequentie als maat voor zwaarte van het drankgebruik}

De keuze woor frequentie als maat woor de zwaarte van het drankgebruik is gebaseerd op theoretische en praktische owerwegingen.

Er wordt in deze studie uitgegatan van de veronderstelling dat drinkgedrag situationeel is bepaald. Verschillen tussen zware en lichte drinkers hangen samen met de beoordeling van de gepastheid wan drinkgedrag binnen situaties. De beoordeling van drinksituaties heeft met name betrekking op de keuze om al dan niet te drinken (Schippers, 1981) en niet zo zeer op de geconsumerde hoevelheid. Dit betekent dat systematische verschillen in de beoordeling van situaties met name in de drinkfrequentie tot uiting moeten komen.

Een belangrijk praktisch voordeel van drinkfrequentie als maat voor zwarte van drankgebruik is dat deze maat een- dimensional is, de scores op deze maat zijn eenduidig. Ook totale constumptie kan als een een-dimensionale maat worden opgevat. In praktijk liggen er aan de totalle consumptie echter tenminste twe dimensies ten grondslag. Ze is het produkt van frequentie en consumptie per keer. Eenzelfde totale consumptie kan het resultat zijn van zeer uiteenlopende patronen in drinkgedrag. lemand die een maal per week 14 glazen drinkt heeft eenzelfde totale consumptie als iemand die iedere dag 2 glazen drinkt. De score voor totale consumptie is dus niet eenduidig.

Een operationalisatie van totale consumptie op basis van twee dimensies zou tot een groot atantal categorieën drinkers leiden. Een praktisch gevolg daarvan zou zijn dat het aantal respondenten per categorie te klein wordt om nog verschillen in drinkgedrag te kunnen analyseren. Dit is hier des te meer het geval omdat het drinkgedrag in verschillende typen situaties wordt onderzocht. Een bijkomend nadeel zou zijn dat de kenmerken die geanalyseerd moeten worden besloten liggen in de definitie van de categorieën drinkers.

De mogelijkheid om drinkers in te delen op basis wan hun kwantiteit per keer is voor de hier uitgewoerde analyses niet geschikt. Een dergelijke indeling kan wellicht geschikt zijn wanneer rechtstreekse effecten, (dronkenschap, katers, verkeersongevallen) van drankgebruik in het dagelijks leven aandacht van studie zijn.

De drinkfrequentie, geoperationaliseerd als het totale aantal drinkgelegenheden, is een rechtstreeks resultaat van de keuzes om al dan niet te drinken. Hoe vaker men besluit te drinken hoe hoger de frequentie. Bijkomend aspect van deze maat is dat een hoge frequentie meer dan een hoge kwantiteit per keer, een hoge consumptie impliceert omdat tijdens elke drinkgelegentheid per definitie tenminste een glas wordt gedronken. 
Bijlage 4.1

De resultaten van de analyses per drinksituatie afzonderlijk bij de mannen 


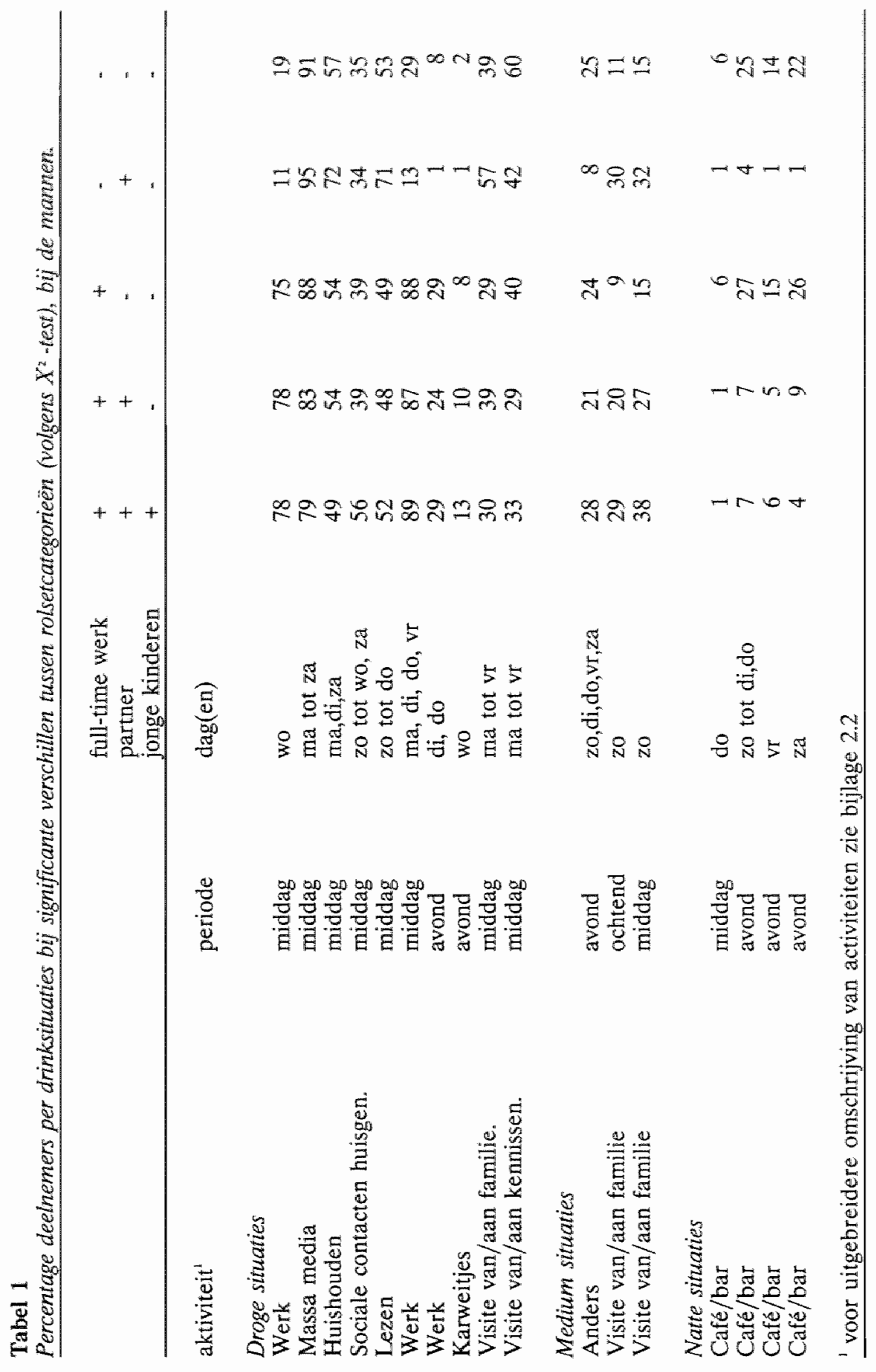




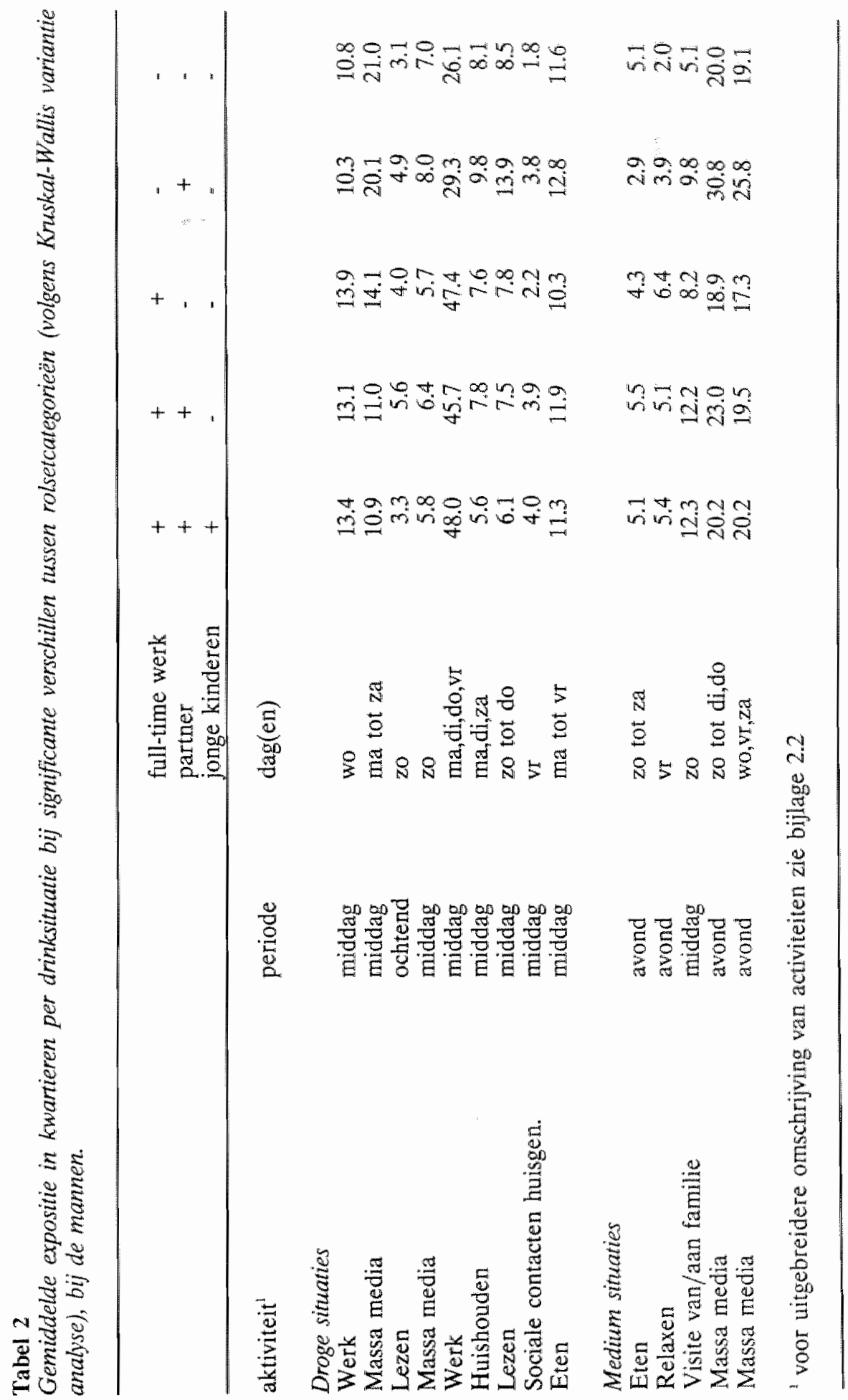




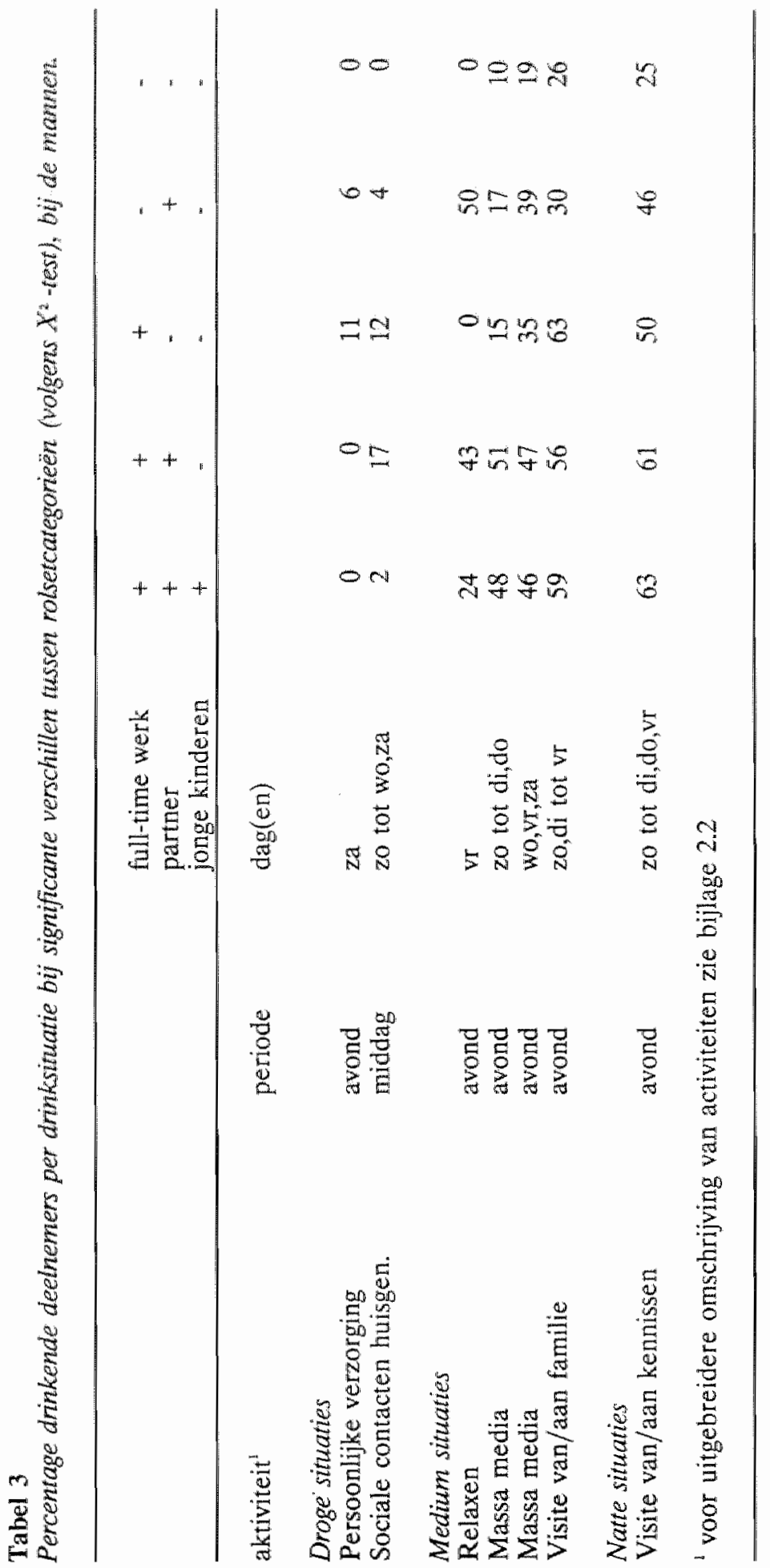


Bijlage 4.2

De resultaten van de analyses per drinksituatie afzonderlijk bij de vrouwen 


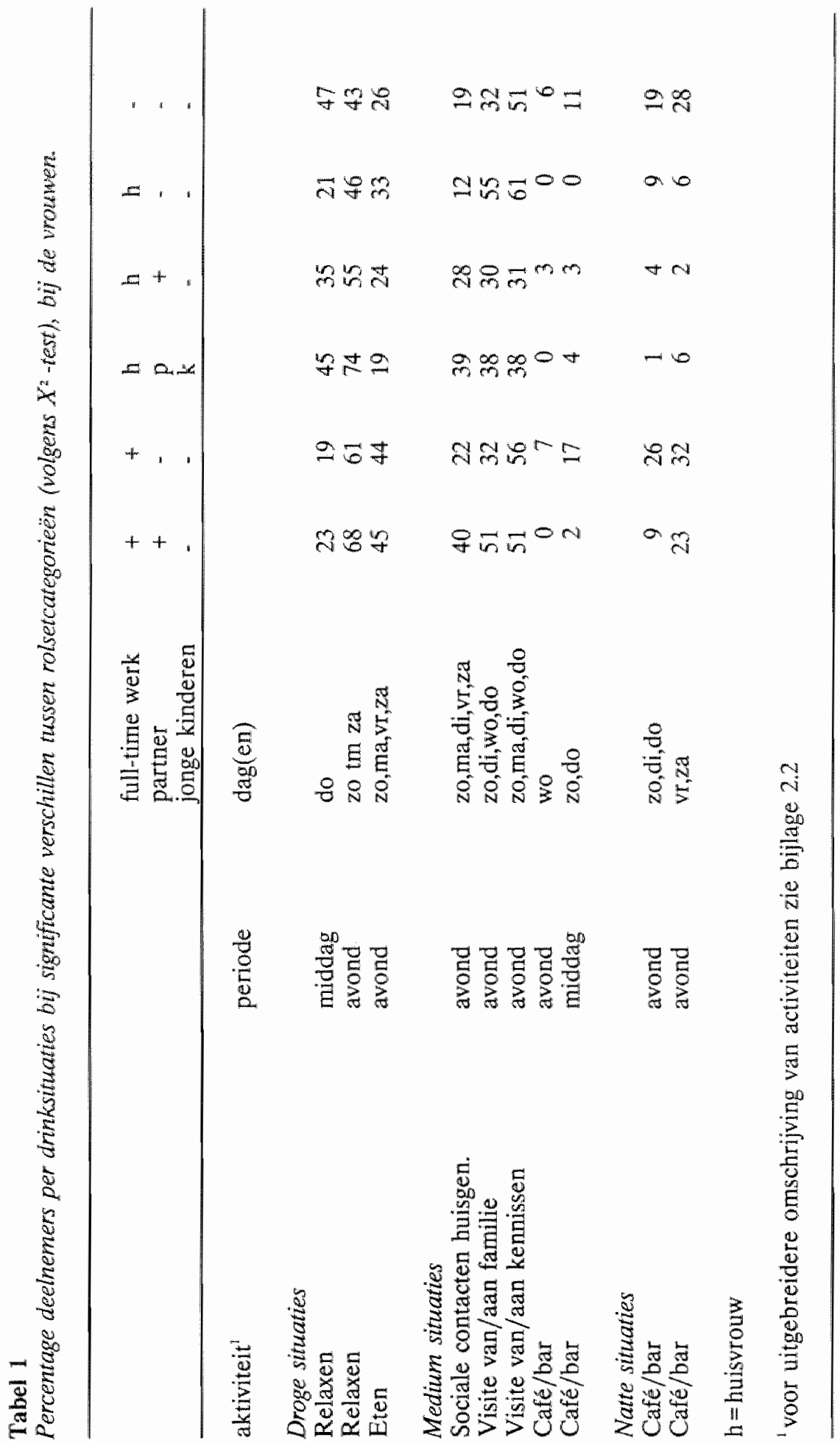




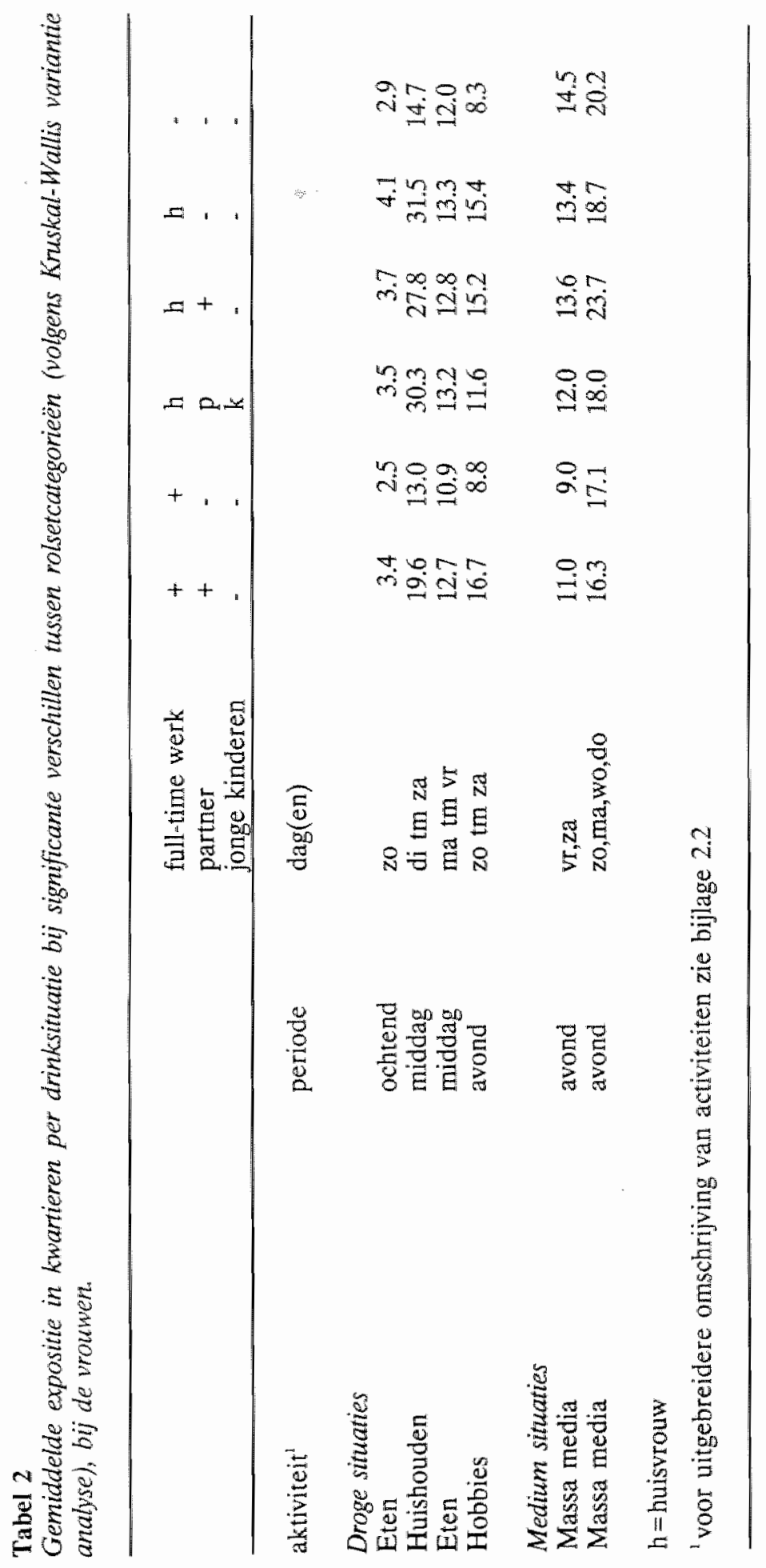




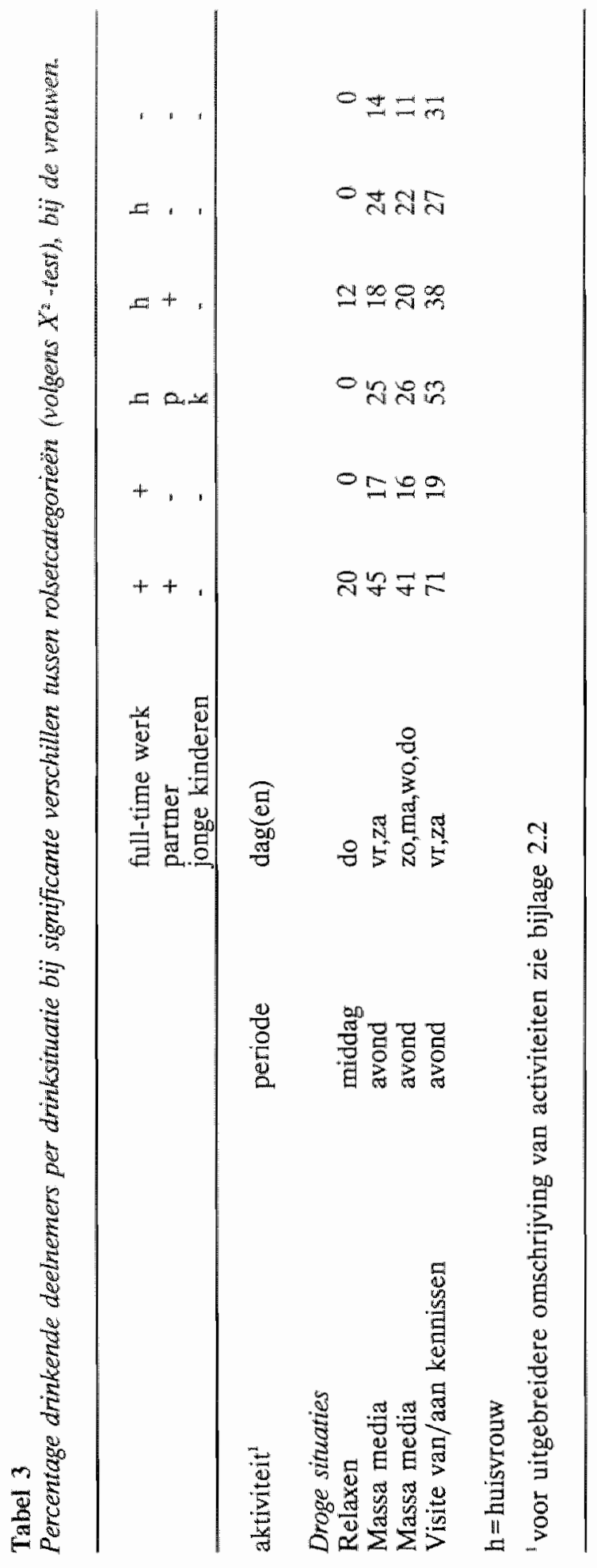




\section{Curriculum Vitae}

I k ben geboren op 22 november 1963. Tk bezocht de basisschool en daarna het VWO. Ik behaalde mijn athenevm-B diploma in 1981 aan het Stedelijk Lyceum te Maastricht. Direct aansluitend begon ik aan de studie Sociale Gezondheidskunde, later Gezondheidswetenschappen, aan de Rijksuniversiteit Limburg. Mijn doctoraaldiploma, afstudeerrichting Gezondheidswoorlichting en -Opvoeding behaalde ik aldaar in september 1985 .

Aansluitend aan mijn universitaire opleiding trad ik in dienst bij de vakgroep Medische Sociologie. Behalve met onderwijstaken heb ik mij daar met name bezig gehouden met het onderzoeksproject 'Structuur van het dagelijks leven en alcoholgebruik'. Van december 1989 tot juli 1990 heb ik onbezoldigd gewerkt aan het hierop gebaseerde proefschift. Sinds augustus 1990 ben ik als dienstplichtig militair, werkzaam bij het Directoraat Personeel Koninklijke Landmacht en wel bij de afdeling Gedragswetenschappen, sectie Toegepast Wetenschappelijk Onderzoek. 